\title{
Significance Testing of Site 41KM225, Kimble County, Texas
}

\author{
Mindy Bonine \\ Michael Chavez \\ Laura Acuna \\ Atkins Global
}

Follow this and additional works at: https://scholarworks.sfasu.edu/ita

Part of the American Material Culture Commons, Archaeological Anthropology Commons, Environmental Studies Commons, Other American Studies Commons, Other Arts and Humanities Commons, Other History of Art, Architecture, and Archaeology Commons, and the United States History Commons

Tell us how this article helped you.

This Article is brought to you for free and open access by the Center for Regional Heritage Research at SFA ScholarWorks. It has been accepted for inclusion in Index of Texas Archaeology: Open Access Gray Literature from the Lone Star State by an authorized editor of SFA ScholarWorks. For more information, please contact cdsscholarworks@sfasu.edu. 


\section{Significance Testing of Site 41KM225, Kimble County, Texas}

\section{Licensing Statement}

This is a work for hire produced for the Texas Department of Transportation (TxDOT), which owns all rights, title, and interest in and to all data and other information developed for this project under its contract with the report producer. The report may be cited and brief passages from this publication may be reproduced without permission provided that credit is given to TXDOT and the firm that produced it. Permission to reprint an entire chapter, section, figures or tables must be obtained in advance from the Supervisor of the Archeological Studies Branch, Environmental Affairs Division, Texas Department of Transportation, 125 East 11th Street, Austin, Texas, 78701. 
TxDOT CSJ No. 2007-01-007

Prepared for

\section{TEXAS DEPARTMENT OF TRANSPORTATION}

Environmental Affairs Division

125 East $11^{\text {th }}$ Street

Austin, Texas 78701-2483

Prepared by

Mindy Bonine and Michael Chavez

with contributions from Laura Acuña

\section{SWCA ENVIRONMENTAL CONSULTANTS \\ 4407 Monterey Oaks Blvd. \\ Building 1, Suite 110 \\ Austin, Texas 78749 \\ www.swca.com}

Principal Investigator

Kevin A. Miller

Texas Antiquities Permit 4183

SWCA Project Number 12723-192-AUS

SWCA Cultural Resources Report No. 2007-454

November 30, 2007 


\section{SIGNIFICANCE TESTING OF SITE 41KM225, KIMBLE COUNTY, TEXAS}

Copyright (C) 2007

Texas Department of Transportation (TxDOT) and SWCA, Inc.

TxDOT and SWCA, Inc., jointly own all rights, title, and interest in and to all data and other information developed for this project under Contract 575XXSA007. Brief passages from this publication may be reproduced without permission provided that credit is given to TxDOT and SWCA, Inc. Permission to reprint an entire chapter, section, figures, or tables must be obtained in advance from the Supervisor of the Archeological Studies Program, Environmental Affairs Division, Texas Department of Transportation, 125 East $11^{\text {th }}$ Street, Austin, Texas 78701. Copies of this publication have been deposited with the Texas State Library in compliance with the State Depository requirements.

Printed by Ginny’s+Merit, Austin, Texas.

jointly published by the

Texas Department of Transportation

Environmental Affairs Division

Archaeological Studies Program

Scott Pletka, Ph.D., Supervisor

Archeological Studies Program, Report No. 104

A. McGraw, Series Editor

and

SWCA, Inc.

Austin, Texas

SWCA Cultural Resources Report No. 2007-454

Texas Antiquities Permit 4183

ISBN: $1-930788-73-8$ 


\begin{abstract}
SWCA Environmental Consultants (SWCA) conducted significance testing excavations at site 41KM225, Kimble County, Texas, on behalf of the Texas Department of Transportation (TxDOT). The tested portion of the site is in TxDOT's right-of-way (ROW) of Farm-to-Market (FM) 2169 on the northern bank of Johnson Fork, a tributary of the Llano River. SWCA performed the investigations under General Services Contract No. 575XXSA007, Work Authorization No. 57520 SA007, and Texas Antiquities Permit 4183. The final report was written under Work Authorization No. 57525 SA007.

In the course of the investigations, SWCA conducted shovel testing, hand excavations, special sampling, and other documentation at the project area. The site is located in the walls of eroding road cuts along FM 2169. Although cultural material was more visible in the east wall, this portion of the site had been impacted by erosion and the construction of a cedar oil processing mill, located just outside the ROW boundary. As the possibility of more intact prehistoric subsurface cultural material was located on the western side of the roadway, hand excavations were initialized on this side. In all, approximately 3.38 $\mathrm{m}^{3}$ were excavated at the site. In addition to the hand excavations, the testing project excavated five shovel tests to define the site limits within the ROW and investigate a feature.
\end{abstract}

The testing determined that the site contains one cultural component, designated Analytical Unit 1 (AU 1), in an alluvial and colluvial setting. AU 1 spans the deposits from the ground surface to a gravel lens at around $70 \mathrm{~cm}$ below surface. AU 1 contains one burned limestone rock feature; debitage, two projectile points, lithic tools, and one charcoal sample were also recovered in the excavation units. One projectile point was also found on the ground surface. One radiocarbon sample was submitted for assay, but the results were inconclusive. Thus, the best data to establish a period(s) of occupation were typological. Although none of the points could be decisively typed, they share characteristics with a Pedernales point, an Early Triangular point, and a Paisano point. The Pedernales point dates to the middle Late Archaic (3,300-2,300 B.P.), and the Early Triangular point dates to the end of the Middle Archaic (5,700-5,500 B.P.). The point recovered from the surface is undiagnostic, but bears some similarity to a Trans-Pecos Paisano point (Transitional Archaic, 2,150-1,350 B.P.), but only a few of the defining characteristics are present. Artifact recovery was sparse, with only two pieces of organic material preserved.

Although the site contains one analytical unit with prehistoric cultural material in an observable natural stratum, the soil compression and bioturbation have mixed the assemblages and associated cultural components. This mixing has compromised the integrity of the cultural deposits; and they cannot be subdivided into separate occupation periods subject to specific research questions. Additionally, the ratio among artifact classes recovered from the site is low (burned limestone, some lithic tools, but almost no organics), and the potential data yield to answer specific research questions is marginal. SWCA recommends that the portion of $41 \mathrm{KM} 225$ within the road ROW is not eligible for National Register of Historic Places (NRHP) listing under Criterion D, 36 CFR 60.4, and is not eligible for State Archeological Landmark (SAL) designation under Criteria 1 and 2 of the Rules of Practice and Procedure for the Antiquities Code of Texas, 13 TAC 26.8. Data recovery investigations are not recommended for the portion of the site within the APE. Portions of the site outside of the ROW have not been fully evaluated. 


\section{TABLE OF CONTENTS}

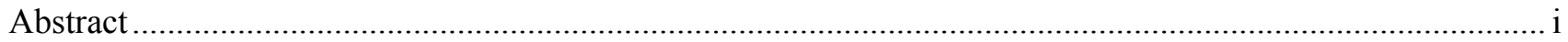

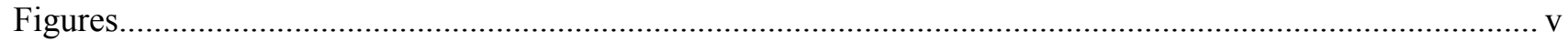



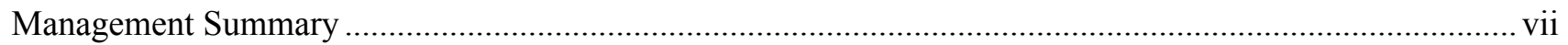

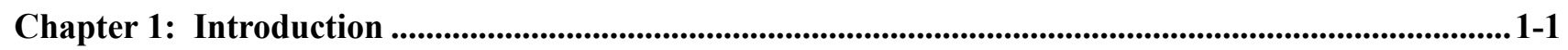

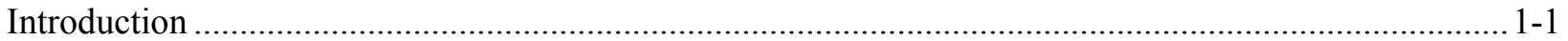

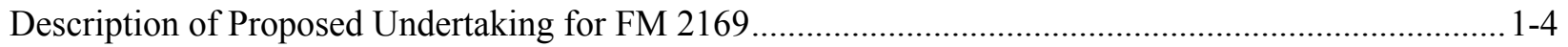

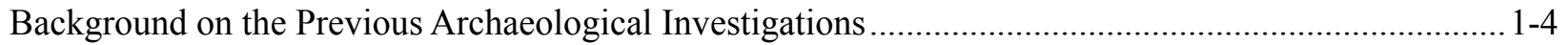

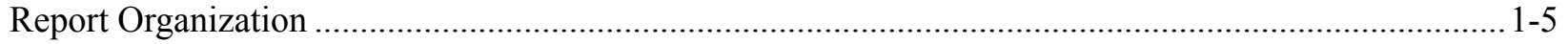

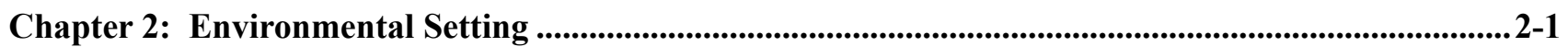

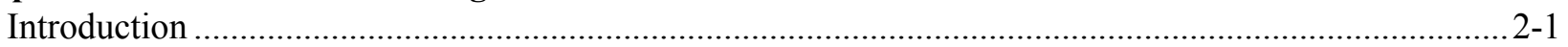

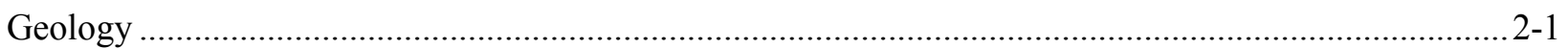

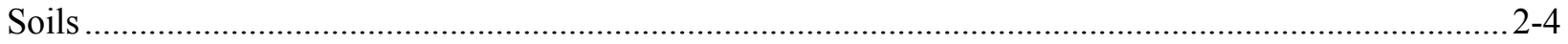

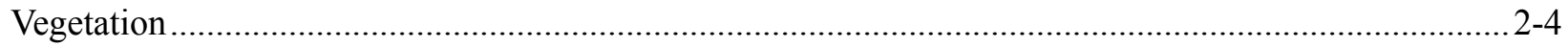

Fauna



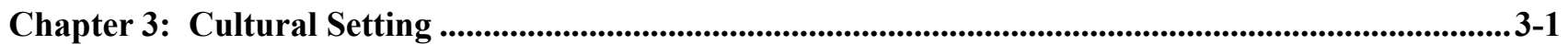

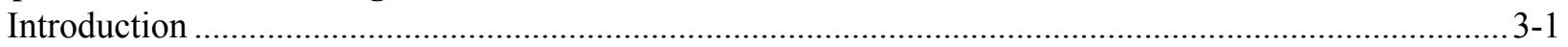



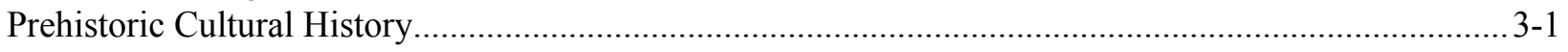

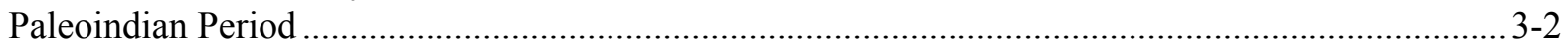

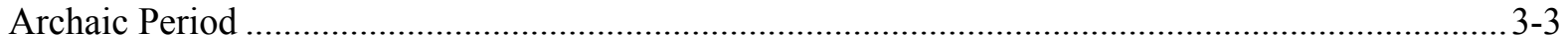

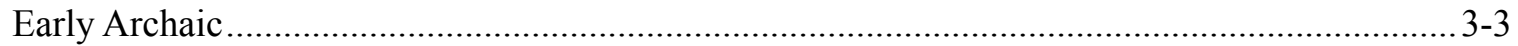

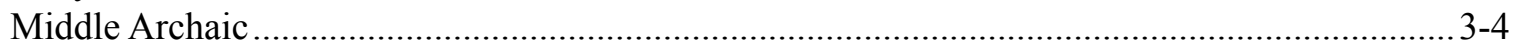

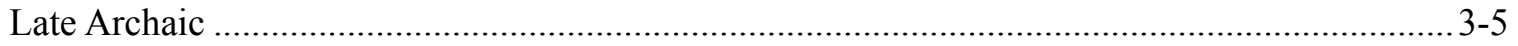

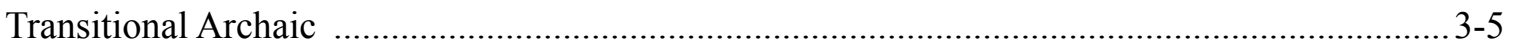

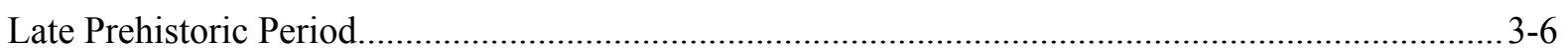



Spanish Colonial/Mexican Independence Period (1630-1820s) .................................................. 3-8

Republic of Texas/Pre-Civil War (1836-1860)......................................................................... 3-9

The Post-Civil War/Reconstruction Period (1865-1880) …............................................................. 3-9

Late Nineteenth/Early Twentieth Century (1880-1940s) ............................................................... 3-10

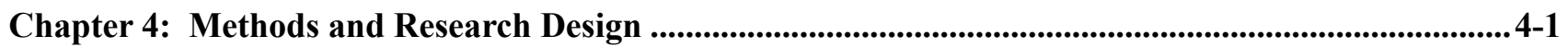

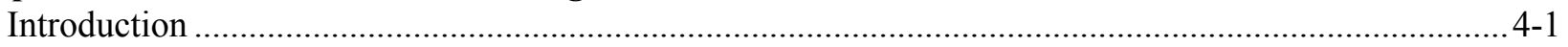

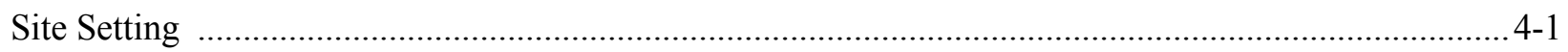

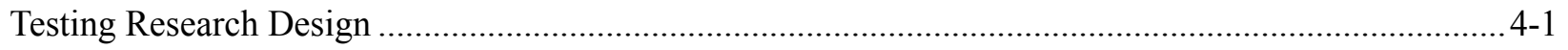

Research Issue 1: Integrity of the Archaeological Deposits ....................................................... 4-3

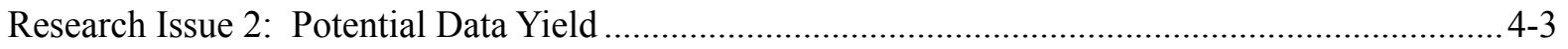

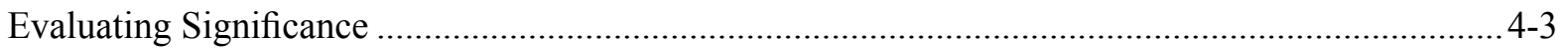

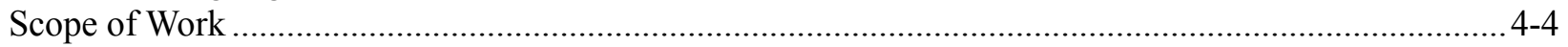

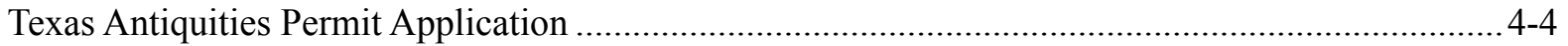

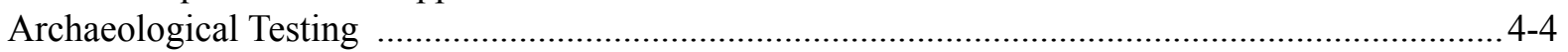

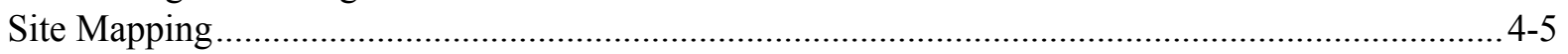

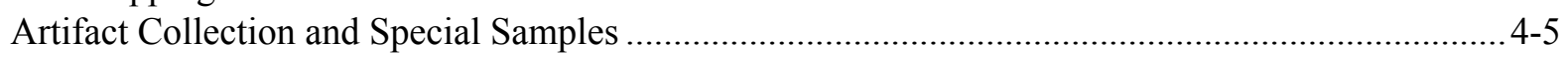






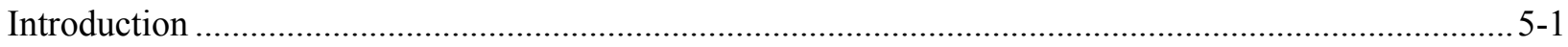

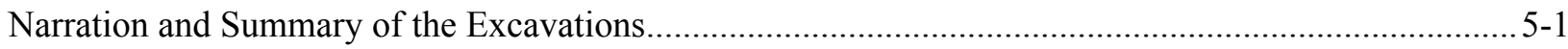

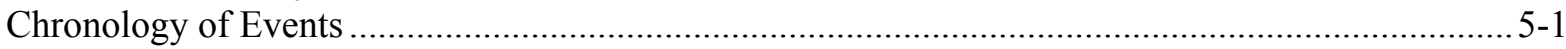

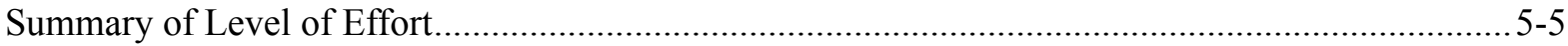

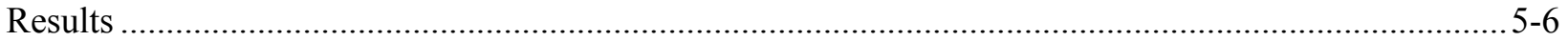

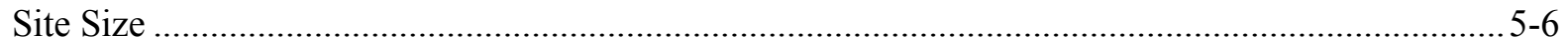

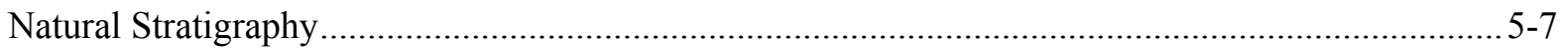

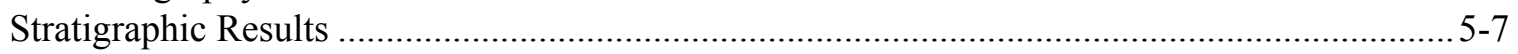

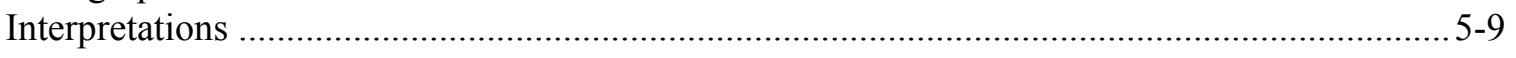



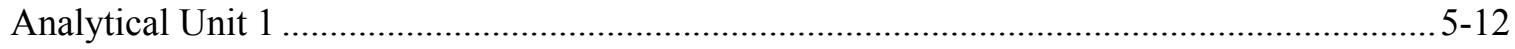

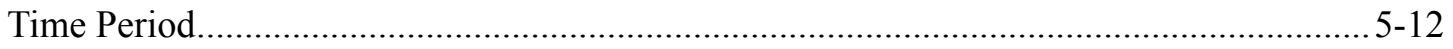

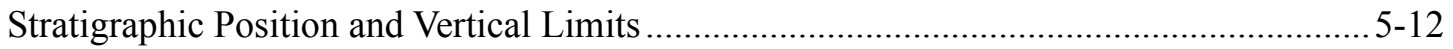



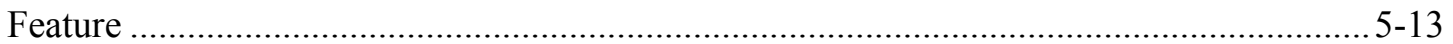

Feature 1 (9-45 cmbs, approximately 99.80-99.44 m) ............................ 5-13

Material Recovered.................................................................................... $5-16$

Chapter 6: Recovered Materials.............................................................................................................................6-1

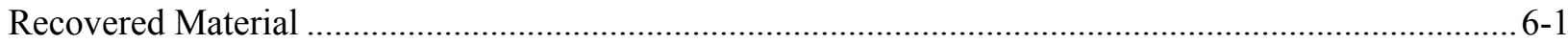





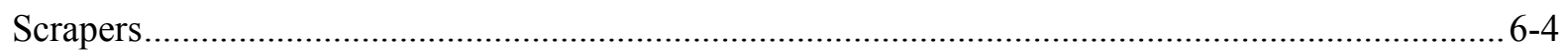



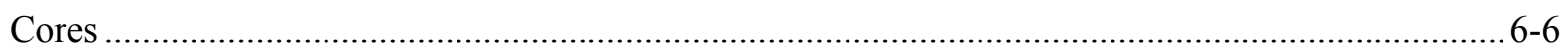

Groundstone

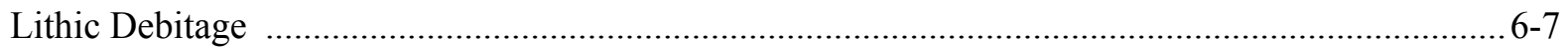

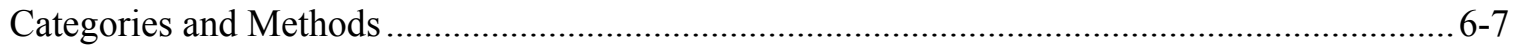

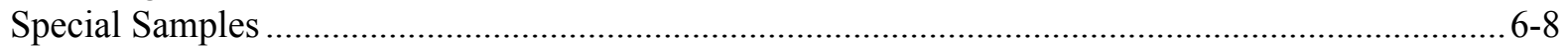



Chapter 7: Data Set for Comparative Literature Review ..................................................................7-1

Archaeological Sites in the Upper Llano River Watershed ............................................................ $7-2$

Tested Archaeological Sites in Kimble and Neighboring Counties .................................................... 7-4



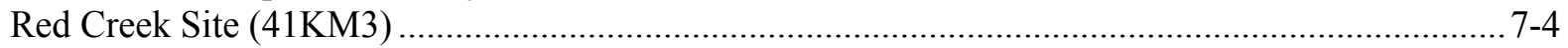

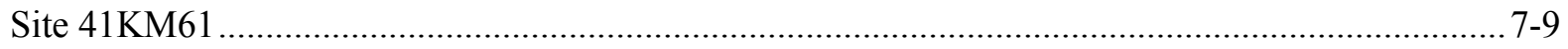



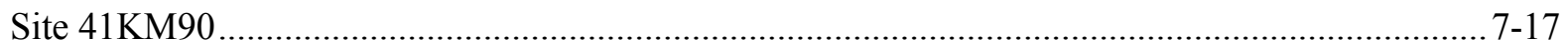

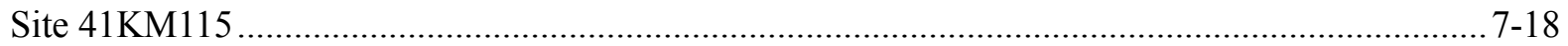



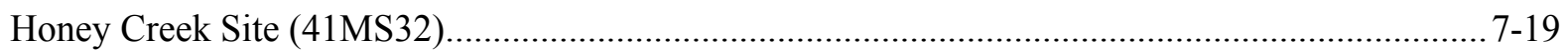

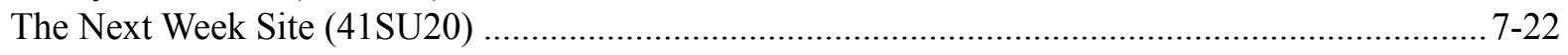

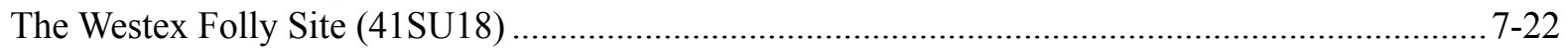



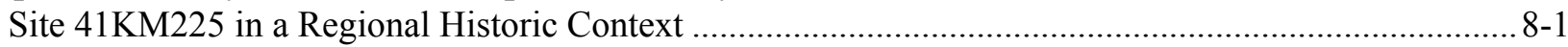



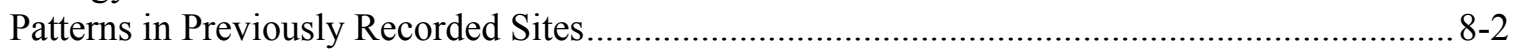




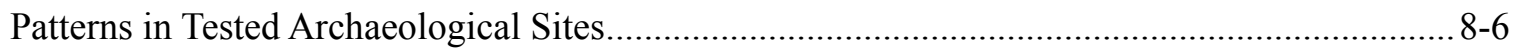

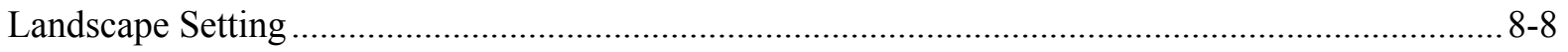

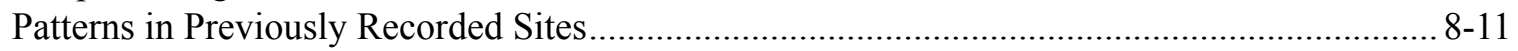

Patterns in Tested Archaeological Sites.......................................................................... 8-12

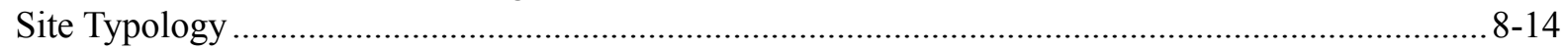

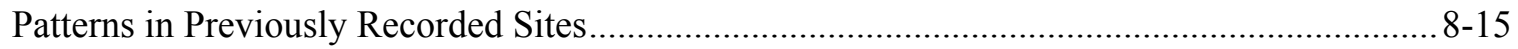

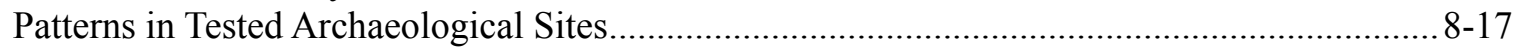

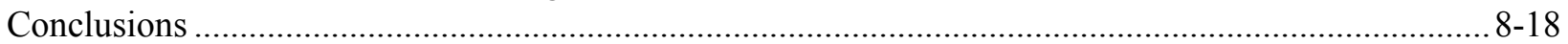

Chapter 9: Summary, Conclusions, and Recommendations.................................................................9-1



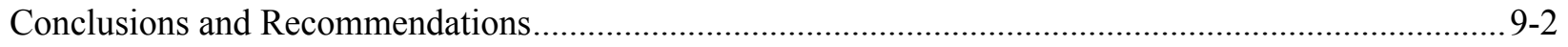

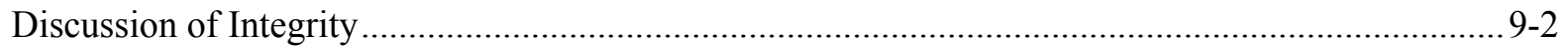

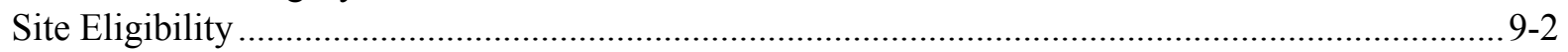

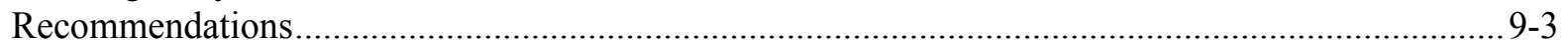

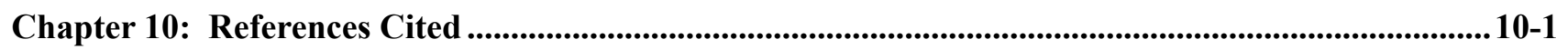

Appendix A: Materials Recovered

Appendix B: Radiocarbon Results

Appendix C: Specimen Inventory 


\section{Figures}

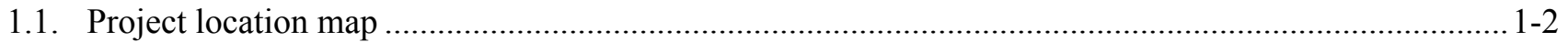

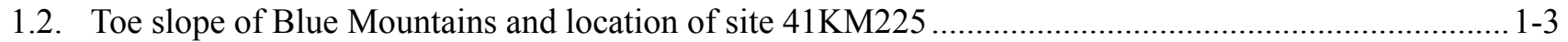

1.3. Existing box culverts under FM 2169 at Johnson Fork ............................................................. 1-4

1.4. Existing tube culverts under FM 2169 at Johnson Fork, just north of the box culverts ........................ 1-5

1.5. Proposed road improvements to the Johnson Fork Crossing at FM 2169 ...................................... 1-6

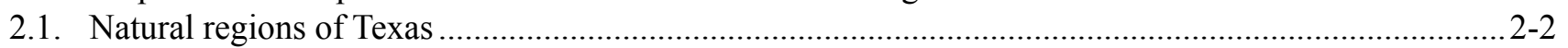

2.2. Map of the geological formations around the Llano River Valley ..................................................2-3



2.4. Limestone cliff along Johnson Fork southeast of site 41KM225 ..................................................2-7

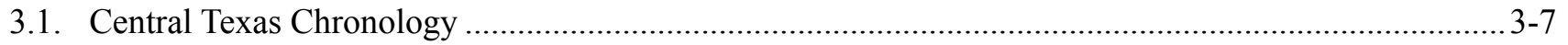

4.1. Location of site $41 \mathrm{KM} 225$, the small intermittant drainage, and the isolated "hill" where most of the

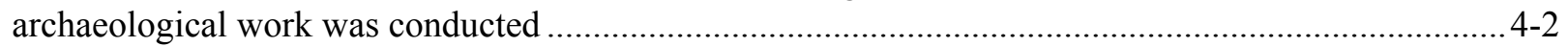

4.2. View of site 41KM225, looking north ..................................................................................... 4-3



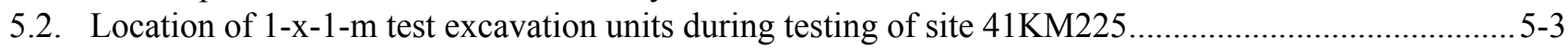

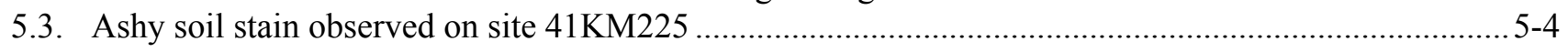



5.5. TU 1 showing the vertical extent of the surface stain on site 41KM255 ........................................5-5

5.6. Profile of Feature 1, a burned rock midden, observed in the cutbank on the east side of FM 2169.......5-6



5.8. Cutbank on the east side of FM 2169, showing multiple gravel lenses and Feature 1 in profile..........5-10

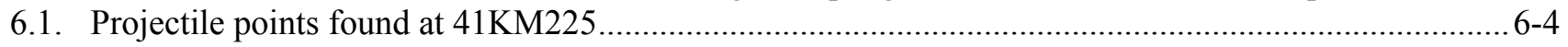

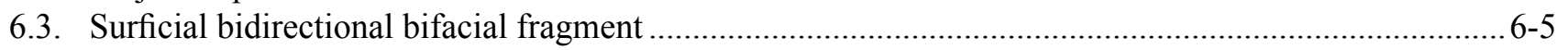

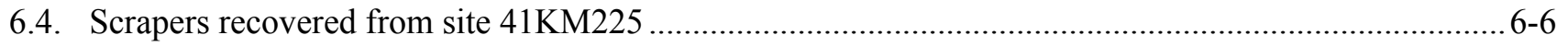

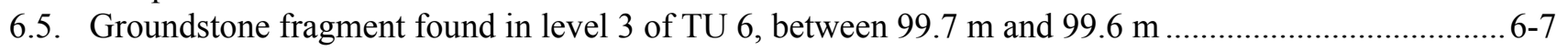

7.1. The Upper Llano River watershed research area.................................................................. $7-2$

8.1. Geographic and landscape settings within the Upper Llano River watershed research area ................ 8-9

8.2. Overlapping study areas of the 18 -county study area............................................................... 8-10

8.3. Previously recorded archaeological sites within the Upper Llano River watershed research are .........8-11

8.4. Locations of tested archaeological sites selected for study in the Upper Llano River watershed research

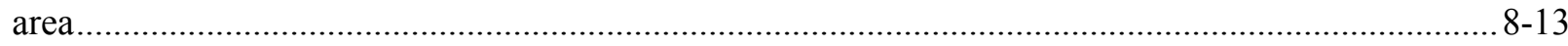




\section{Tables}

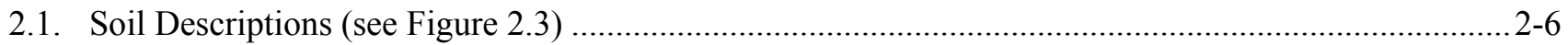

5.1. Excavated Volume of 1-x-1-m Excavation Units at 41KM225 …................................................5-6

5.2. Matrix of Recovered Materials from South to North Showing Areas of Highest Density.................. 5-11

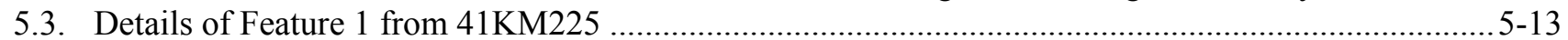

5.4. Burned Rock Densities and Materials Recovered From Feature 1 Shovel Tests ...............................5-14

5.6. Materials Recovered From Test Excavation Units by Context.........................................................5-15

5.5. Total of All Materials Recovered From 41KM225 Testing ......................................................... 5-15

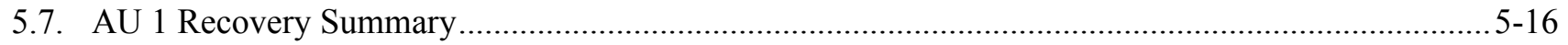



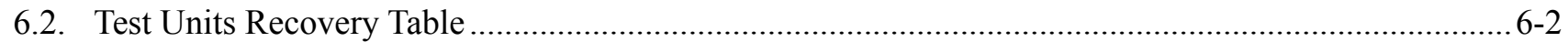

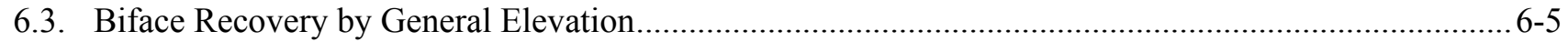

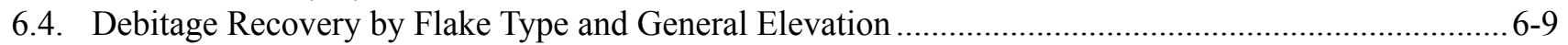

7.1. Previously Recorded Archaeological Sites on Hillslopes................................................................ 7-5

7.2. Previously Recorded Archaeological Sites on Hilltops ................................................................... 7-8

7.3. Previously Recorded Archaeological Sites on Hilltop/Hillslopes ..................................................... 7-9

7.4. Previously Recorded Archaeological Sites on Terraces .............................................................. 7-10

7.5. Previously Recorded Archaeological Sites on Upland Drainages ................................................... 7-15

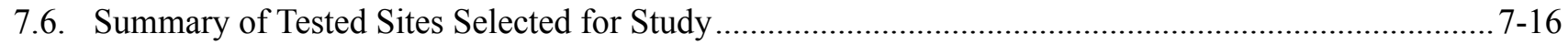

7.7. Chronology Used by Researchers of the Red Creek Site (41KM3) …............................................ 7-17

7.8. Chronology Used by Researchers of 41KM61 and 41KM62 ....................................................... 7-17

7.9. Chronology Used by Researchers of the Honey Creek Site (41MS32) During Testing...................... 7-20

7.10. Chronology Used by Researchers of the Honey Creek Site (41MS32) During Data Recovery ........... 7-21

7.11. Chronology Used by Researchers of the Westex Folly Site (41SU18) ............................................. 7-23

8.1. Selected Sites in the Upper Llano River Watershed that Contain Chronology Information and Used in

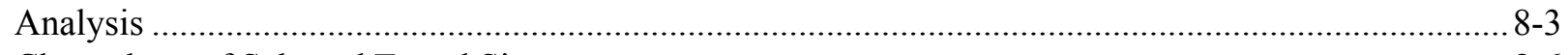



8.3. Recalibrated Chronology in Radiocarbon Years of the Tested Sites Selelcted for Study ....................... 8-7

8.4. Landscape of Selected Tested Sites ......................................................................................... 8

8.5. Matrix of Previously Recorded Archaeological Sites in the Upper Llano River Watershed................ 8-15

8.6. Topography of Selected Tested Sites ........................................................................................ 8-17 


\section{MANAGEMENT SUMMARY}

Project Title: Significance Testing of Site 41KM225, Kimble County, Texas.

TXDOT CSJ Number: 2007-01-007.

SWCA Project Number: 12723-192-AUS.

Project Description: TxDOT proposes to replace the existing crossing structures at FM 2169, Kimble County, Texas with a 14-x-10-x-40-foot multi-box culvert system made with pre-cast single cell box culverts (10-foot span) and create wider approaches to the crossings. The roadway at the approach to the culverts would be two 12-foot travel lanes with 8-foot shoulders. No additional ROW will be required. Site 41KM225, a prehistoric campsite with surficial and sub-surface elements, is located within the area of potential effect for the project. As the site had not been assessed for its eligibility for inclusion to the NRHP or for listing as a SAL, significance testing was conducted.

Location: Site 41KM225 is located on the north side of Johnson Fork, at the middle crossing of Johnson Fork and FM 2169, southeast of the City of Junction, in central Kimble County, Texas. The site is located within public property controlled by TxDOT, as well as adjacent private land. On the publicly owned portion of the site, FM 2169 has significantly impacted the site, destroying it where the road has been cut through the hillside on which the site is located. Although the site extends outside of the FM 2169 ROW, the testing project was confined to TxDOT property. The site appears on the Segovia (TX) USGS 7.5-minute topographic map.

Excavated Volume: $3.38 \mathrm{~m}^{3}$.

Principal Investigator: Kevin A. Miller.

Texas Antiquities Permit: 4183.

DATES OF Work: July 24-28, 2006.

Purpose of Work: As the construction project will involve federal funds from the Federal Highway Administration (FHWA) and involves state land controlled by the San Angelo District of TxDOT, investigations were conducted in compliance with the Texas Antiquities Code; the National Historic Preservation Act (NHPA); the Programmatic Agreement between the FHWA, the Advisory Council on Historic Preservation (ACHP), TxDOT, and the Texas Historical Commission (THC); and the Memorandum of Understanding between TxDOT and the THC.

Number of Sites: One, 41KM225.

ELIGIBILITY OF Sites: The portion of 41KM225 within the road ROW is not eligible for NRHP listing under 36 CFR 60.4 and doesn't warrant SAL designation under 13 TAC 26.8.

RECommendations: Data recovery investigations are not recommended.

CuRation: The artifacts and records from the project will be curated at the Texas Archeological Research Laboratory (TARL). 



\section{Chapter 1}

\section{INTRODUCTION}

\section{Mindy Bonine}

\section{INTRODUCTION}

Site 41KM225, a small prehistoric campsite, occupies a small portion of a terrace overlooking Johnson Fork, a tributary of the Llano River in Kimble County, Texas (Figure 1.1). Johnson Fork flows from south to north, and weaves its way through the Blue Mountains to the Llano River valley near Junction. The wide meanders of Johnson Fork have created large toe slopes below the Blue Mountain escarpments, and it is upon one of these toe slopes that the terrace containing site $41 \mathrm{KM} 225$ sits. The site is approximately $7.9 \mathrm{~km}$ (4.92 miles) south of the confluence of Johnson Fork and the Llano River.

In the rugged broken topography of this area, the earliest trails, and later roads, often followed the most easily traversed terrain features, generally somewhere along the terraces of streams and rivers and the toe slopes of surrounding scarps. Long before Interstate Highway (IH)-10 was built, Farm-to-Market (FM) 2169 was constructed in this setting to connect the small towns of Junction and Segovia. This roadway crosses Johnson Fork three times as the relatively linear roadway encounters the back-and-forth meanders of the creek. At the middle crossing, about $2.2 \mathrm{~km}$ (1.37 miles) north of IH-10 at Segovia, FM 2169 bisects a terrace on the north bank of Johnson Fork (which is running roughly east-west at this point), which contains the remains of a prehistoric occupation site. The site sits on the terrace at the southern portion of one of the large western sloping toe slopes of the Blue Mountains (Figure 1.2). The southern edge of this toe slope has been incised by FM 2169 , bisecting site $41 \mathrm{KM} 225$. The portion of the site east of the roadway boundary sits on a narrow flat portion of the toe slope, just beneath a steep rise in elevation leading to the Blue Mountains. The portion of the site west of the roadway occupies a slowly decreasing elevation before it is truncated by a deeply incised intermittent drainage to Johnson Fork.

Site 41KM225 was discovered by archaeologists from the Texas Department of Transportation (TxDOT; formerly the State Department of Highways and Public Transportation [SDHPT]) during an archaeological survey of the area prior to the implementation of a road improvement project for FM 2169. At the time it was determined that more research was needed to determine if the site retained sufficient integrity and information potential to be eligible under Criterion D of the National Register of Historic Paces (NRHP) or for listing as a State Archeological Landmark (SAL). As such, SWCA Environmental Consultants (SWCA) was contracted by the Environmental Affairs Division (ENV) of TxDOT to conduct significance testing at site $41 \mathrm{KM} 225$.

When the archaeological survey began, site $41 \mathrm{KM} 225$ was clearly visible eroding from the road cuts along both sides of FM 2169, north of the second crossing of Johnson Fork. Although cultural material was more visible in the east wall, including evidence of a burned rock midden, this portion of the site had been impacted by erosion and the construction of a cedar oil processing mill, located on the east side of the roadway between it and the steep rise in elevation to the Blue Mountains. As the possibility of more intact prehistoric subsurface cultural material was located on the west side of the roadway, the current investigation focused on investigating this portion of the site 
1-2 Chapter 1








Figure 1.2. Toe slope of Blue Mountains. 
with test excavation units, as well as determining the overall site limits where possible. Although the site extends outside of the current 100-foot right-of-way (ROW) of FM 2169, the significance testing investigations were limited to the portion of the site within the FM 2169 ROW.

SWCA performed the investigations under General Services Contract \#575XXSA007, Work Authorization \#575 20 SA007. The Texas Historical Commission (THC) issued Texas Antiquities Permit 4183 to Principal Investigator Kevin A. Miller. Project Archaeologist Mindy Bonine supervised the daily fieldwork, which took place July 24-28, 2006. The completion of this final report was conducted under Work Authorization \#575 25 SA007.

\section{Description of Proposed UNDERTAKING FOR FM 2169}

Currently, FM 2169 is a two-lane paved road (10 feet wide) with no shoulders. The length of road between Junction and Segovia crosses Johnson Fork three times. At the middle crossing of FM 2169 and Johnson Fork, two single box culverts (10-x-6-x-34 feet) have been placed under the road to accommodate the passage of the majority of the water flow, and two smaller tube culverts (4-x-36 feet) are located where a small trickle of water is present (Figures 1.3 and 1.4). TxDOT is proposing to replace these current crossing structures with 14 10-x-10-x-40-foot multi-box culvert systems made with pre-cast single cell box culverts, as well as create wider approaches to the crossings (Figure 1.5). The overall width of the approach will be 40 feet, with two 12-foot travel lanes and two 8 -foot shoulders. The road will return to two 10 -foot wide travel lanes with no shoulders beyond the crossings. The overall length of the improvements is 1,350 feet $(0.411 \mathrm{~km})$, and the project does not require additional ROW.

Approximately 600 feet $(182 \mathrm{~m})$ north of the tube culverts, site $41 \mathrm{KM} 225$ is located on both sides of FM 2169. It is within the Area of Potential Effects (APE) of direct and indirect impacts related to the widening of the roadway, at the northern end of the APE.

\section{Background on the Previous}

\section{Archaeological Investigations}

In May 2006, archaeologists from TxDOT conducted an archaeological survey of two points where FM 2169 crosses Johnson Fork that would be potentially impacted by the construction of multi-box culvert structures and road improvements (Arnn and Abbott 2006). The survey stemmed from the need for TxDOT to replace the existing crossing structures over the creek as described above. During those investigations, site 41KM225 was discovered north of Johnson Fork on both sides of FM 2169.

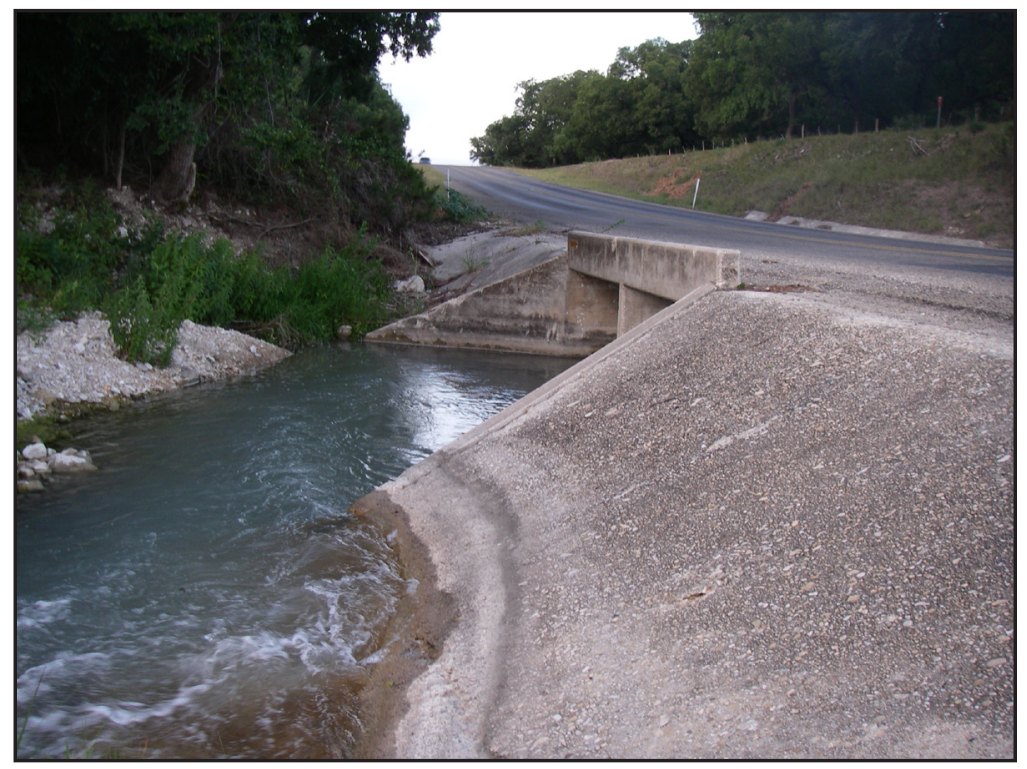

Figure 1.3. Existing box culverts under FM 2169 at Johnson Fork (facing south). 




Figure 1.4. Existing tube culverts under FM 2169 at Johnson Fork, just north of the box culverts (facing west).

The TxDOT pedestrian survey consisted of a surface inspection only (Arnn and Abbott 2006). One prehistoric archaeological site was observed eroding out of the road cut within the ROW of FM 2169, on the north side of the middle crossing of Johnson Fork. The site was located at the edge of a large slope leading towards the north bank of Johnson Fork, approximately $130 \mathrm{~m}$ from the edge of the creek. The site was most visible in the eastern road cut, where a possible prehistoric burned rock midden was observed extending from the surface to a depth of about 30 $\mathrm{cm}$ below surface (cmbs). However, this portion of the ROW had eroded away almost to the fence line marking the boundary of a cedar oil processing mill. The western road cut did not contain midden material, but did have abundant chert debitage, burned rock, and mussel shell within the top $30 \mathrm{cmbs}$ (Arnn and Abbott 2006; Texas Archeological Research Laboratory [TARL], 41KM225 site form). Artifacts were also seen on the surface at the top of the slope above the road cut between the edge of the road cut and the fence line defining the edge of the ROW. No diagnostic artifacts were located during the survey, and other than the possible burned rock midden, no features were observed.

The space between the road cut and the edge of the ROW on the west side of FM 2169 appeared to be about 4-5 $\mathrm{m}$ wide, and contained shallow but intact archaeological deposits. The eastern side of the site had been severely impacted by erosion, and likely the construction of the cedar oil processing mill as well (Arnn and Abbott 2006). The road had bisected the site, resulting in the removal of a $50-x-40-m$ area, including much of the burned rock midden (TARL, 41KM225 site form). The researchers anticipated that the widening of the roadway would additionally impact the site, accelerating the erosion. The intact portion of the site within the ROW, i.e., the west side, was recommended for testing to determine its integrity and information potential.

\section{Report Organization}

This report presents the results of SWCA's testing investigations at site 41KM225. Chapter 2 provides an overview of the natural setting of the project area, and Chapter 3 presents a summary of the cultural setting, including discussions on previous archaeological investigations and a regional cultural history. The research design and methods used to conduct the fieldwork and analysis are described in Chapter 4. The results of the investigations, including a narration of the excavations as they progressed, descriptions of the natural and cultural stratigraphy, the distributions of cultural material, and a general summary of the site, are presented in Chapter 5. An analysis and detailed description of the recovered materials is described in Chapter 6. 


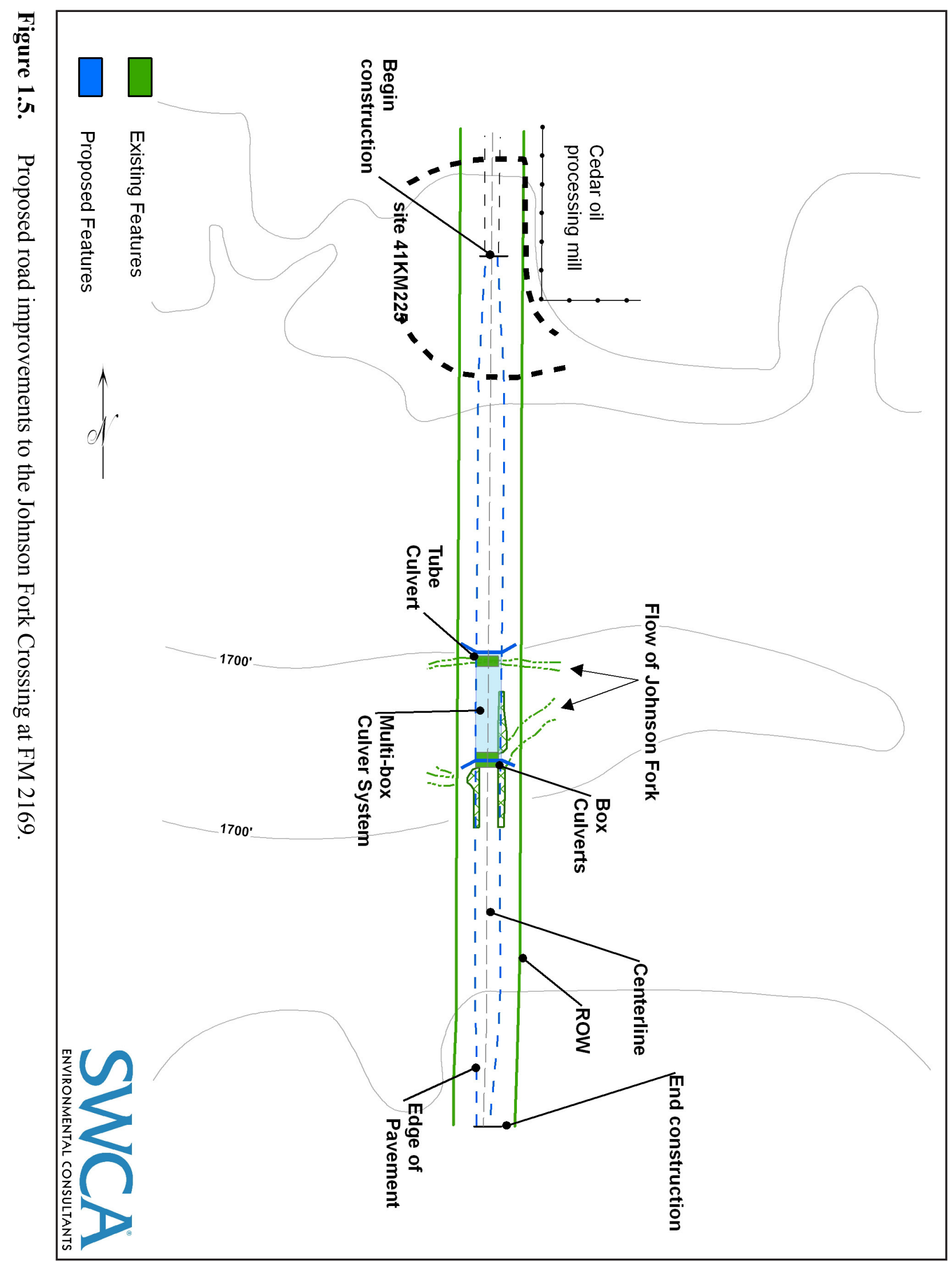


Chapter 7 presents the data set used to conduct a comparative analysis and place site 41KM225 in a wider prehistoric context, and Chapter 8 present the results of the comparative analysis and a general discussion of the study. Chapter 9 summarizes the content of the report and makes recommendations on the significance of site $41 \mathrm{KM} 225$, and Chapter 10 consists of references cited. Supporting documentation in the form of appendices include tables of materials recovered, the results of the radiocarbon assays, and a specimen inventory. 



\section{Chapter 2}

\section{EnVironmental Setting}

\section{Mindy Bonine and Laura Acuña}

\section{INTRODUCTION}

Site 41KM225 is located in west-central Texas within the Live Oak-Mesquite Savanna of the Edwards Plateau (Figure 2.1). The Edwards Plateau comprises the area of Texas generally known as the "Hill Country," and is bounded on the east and south by the Balcones Fault (the surface expression of this fault is the Balcones Escarpment, which separates the Hill Country from the Texas Coastal Plain), on the north by the Rolling Plains, and on the west by the Trans Pecos and a small portion of the High Plains (Natural Heritage Policy Research Project [NHPRP] 1978). In addition, the north-eastern edge of Kimble County touches the Llano Uplift, which is a distinct mound of granite and sandy soils surrounded by the Edwards Plateau.

The environmental and climatic conditions of this region have fluctuated considerably over the past 12,000 years, and the current conditions were not always prevalent in and around site 41KM225. Thus, the discussion below provides an overview of the present-day environmental setting, for which we have the most information, followed by a brief history of the regional paleoenvironmental record as it is currently understood. This discussion is based on the results of field investigations performed by SWCA archaeologists and a review of relevant literature.

\section{GeOLOGY}

A review of the data as mapped by the Bureau of Economic Geology provided the basis for the general geology around site 41KM225. The Llano
River Valley west of the Llano Uplift slices through Lower Cretaceous Segovia Member limestone and dolomite bedrock on the south side of the river valley or a combination of Segovia Member and Fort Terrett Member limestone and dolomite on the north side of the valley (Figure 2.2). Segovia Member limestone and dolomite is about 170-300 feet thick, and contains three bands: cherty light gray limestone with numerous shell fragments at the top, medium brownish-gray porous and cherty dolomite in the middle, and light yellowish-gray marly limestone at the bottom (Barnes 1981:4). Fort Terrett Member limestone and dolomite is a 150-230-foot deep formation that contains porcelaneous fine grained igneous limestone at the top, gray cherty limestone and dolomite in the middle, and nodular limestone with a thin yellow clay band at the base (Barnes 1981:4).

The thin strip of lowland valley that surrounds the river courses, particularly the Llano River (including the north and south branches) and Johnson Fork, contain a mixture of Lower Cretaceous period Hensell Sand at the higher elevations, Pleistocene and Holocene period alluvial fan deposits around major bends in the rivers, and Holocene alluvial floodplain deposits nearest the rivers themselves (Barnes 1981:3, 5). Site 41KM225 is located in an area underlain by Hensell Sand. Hensell Sand is composed of sand, silt, clay, and cemented conglomerates of pebbles and cobbles of Paleozoic and Precambrian rocks. These sands are formed along the shoreward facies of the Glen Rose Limestone (Barnes 1981:5), which in combination with Edwards Limestone, form the Blue Mountains to the east. 


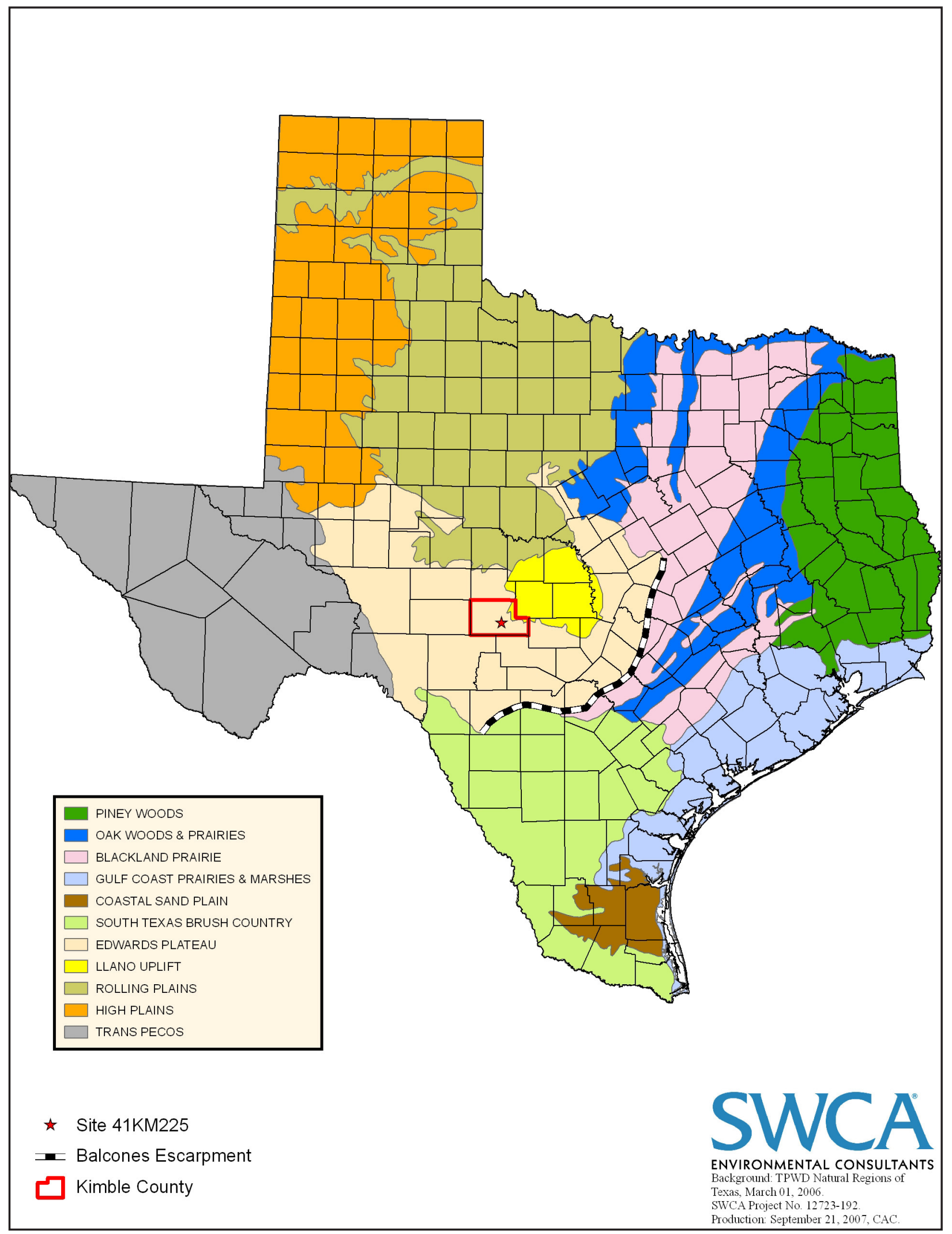

Figure 2.1. Natural regions of Texas. 


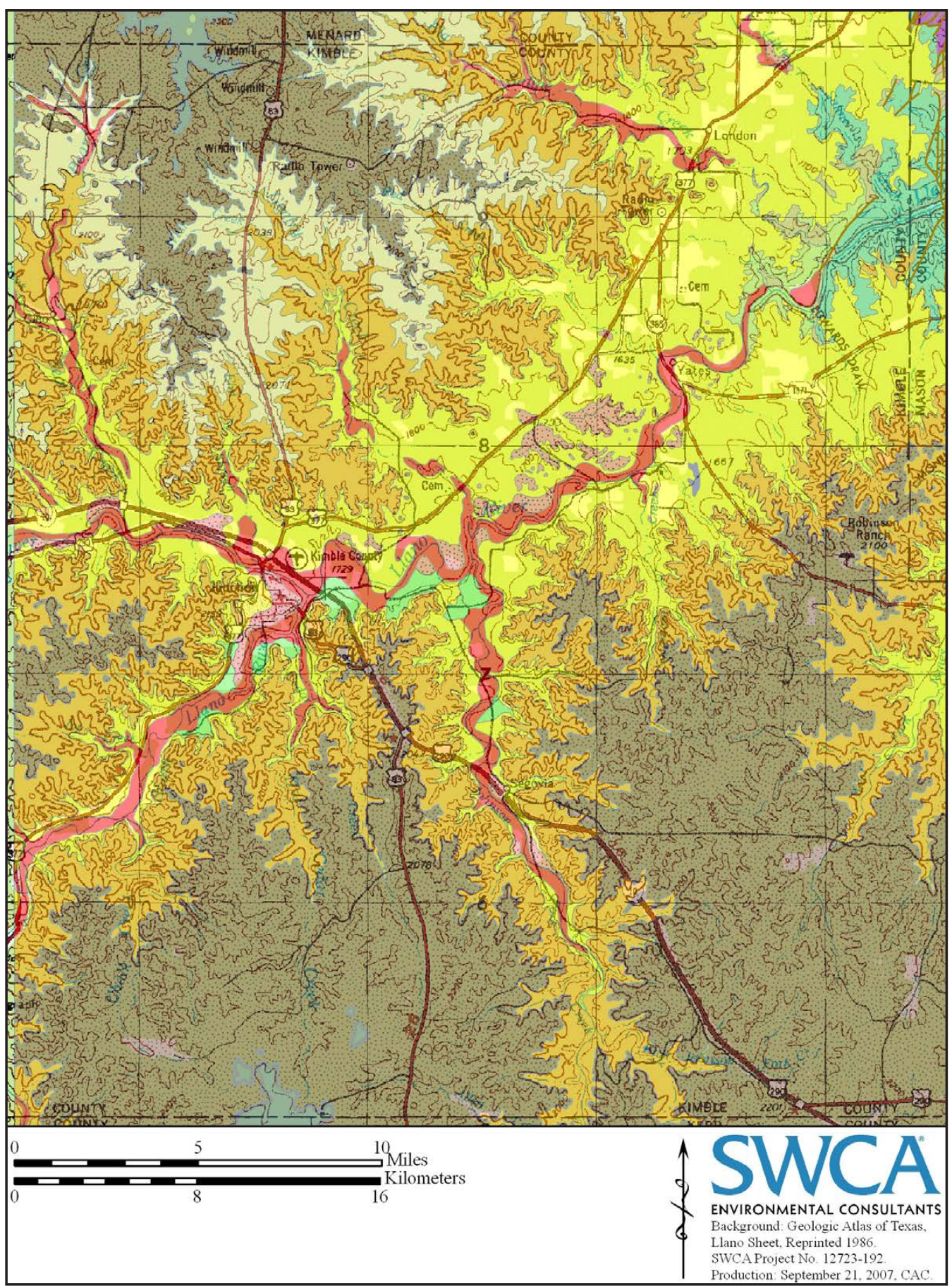

\begin{tabular}{|c|c|c|}
\hline \multicolumn{3}{|l|}{ Geology } \\
\hline Quaternary Alluvium & Buda Limestone & $\square$ Hensell Sand \\
\hline Quaternary Alluvial fan deposits & Del Rio Clay & Smithwick Formation \\
\hline Quaternary Colluvium & Segovia Member & Marble Falls Limestone \\
\hline Quaternary Fluviatile terrace deposits & $\square$ Lower Segovia and Upper Ft. Terrell Members & Mississipian and Devonian rocks undividec \\
\hline Quaternary Playa deposits & Fort Terrett Member & Ellenburger Group \\
\hline & & Wilberns Formation \\
\hline
\end{tabular}

Figure 2.2. Map of the geological formations around the Llano River Valley. 


\section{SoILS}

The soils for the site consist of Shep clay loams, 1-5 percent slopes, with Dev very gravelly loams to the south in the Johnson Fork floodplain. The Shep clay loams are deep, well-drained gently sloping soils found on upland foot slopes (Blum 1982:23). These soils formed in loamy alluvial and colluvial sediments and contain increasing amounts of caliché pebbles and concretions of calcium carbonates with depth (Blum 1982:59). The Dev very gravelly loams are described as frequently flooded, gently sloping soils found on bottomlands along streams. These deep soils are very gravelly and loamy, formed in calcareous, alluvial sediment of recent origin (Blum 1982:53).

The soils and geology as well as aerial and topographic maps indicate that the site sits on a large alluvial and colluvial toe slope of the western extent of the Blue Mountains (see Figure 1.2). Two large drainage valleys have incised the eastern upland area (Blue Mountains) creating the large, low toe slope. The Soil Survey of Kimble County, Texas (Blum 1982) shows undulating Tarrant soils over the Edwards Limestone to the east of the site. Moving west, the soils become Real-Brackett complex, hilly, and Tarrant-Rock outcrop complex, steep, before leading to the Shep clay loams that are mapped at the site location (Figure 2.3; Table 2.1). These mapped soils fit with typical alluvial and colluvial toe slope deposits indicated by the surface geology and topography of the area. The Tarrant soils are very shallow to shallow soils found on bedrock. The Real-Brackett complex consists of very shallow to shallow soils found along the base of limestone hills. The Tarrant-Rock outcrop complex are steep very shallow to shallow soils and rock outcrops found along convex hillside slopes and exposures of limestone bedrock on escarpments.
Overall, the area on which site 41KM225 sits appears to predominately contain alluvial and colluvial deposits associated with the toe slope. The proximity of the site to Johnson Fork lends to the possibility of alluvial deposits associated with the waterway. However, the sites location on the outside meander along the northern highenergy portion of the northward flowing Johnson Fork lends more to the erosion of landmass than to deposition. An example of the high energy provided by Johnson Fork is a large erosional cut in the limestone bedrock located just south of the site, and along the same bank as the site (Figure 2.4).

\section{Vegetation}

As mentioned above, site 41KM225 lies within the Live Oak-Mesquite Savanna of the Edwards Plateau. This natural subregion is described as flat to rolling topography with oak and mesquite woods on grassland (NHPRP 1978). This area is also known as the central region of the Balconian biotic province (Blair 1950). This province has highly variable vegetation of the Edwards Plateau and Hill Country (Spearing 1991:24). Typical canopy cover of the Edwards Plateau consists of Texas oak (Quercus texana), live oak (Quercus virginiana), blackjack oak (Quercus marilandica), Lacey oak (Quercus glaucoides), plateau live oak (Quercus fusiformis), Mexican cedar (Juniperus mexicana), mesquite (Prosopis glandulosa), and some bald cypress (Taxodium distichum) (Blair 1950; Simpson 1988; Spearing 1991).

Grasses that are typical of the Edwards Plateau region include switchgrass (Panicum virgatum), Indian grass (Sorghastrum nutans), beardgrass (Bothriochloa spp.), sideoats grama (Bouteloua curtipendula), King Ranch bluestem (Bothriochloa ischaemum), little bluestem (Schizachyrium scoparium), Canada wildrye (Elymus canadensis), curly mesquite (Hilaria belangeri) 


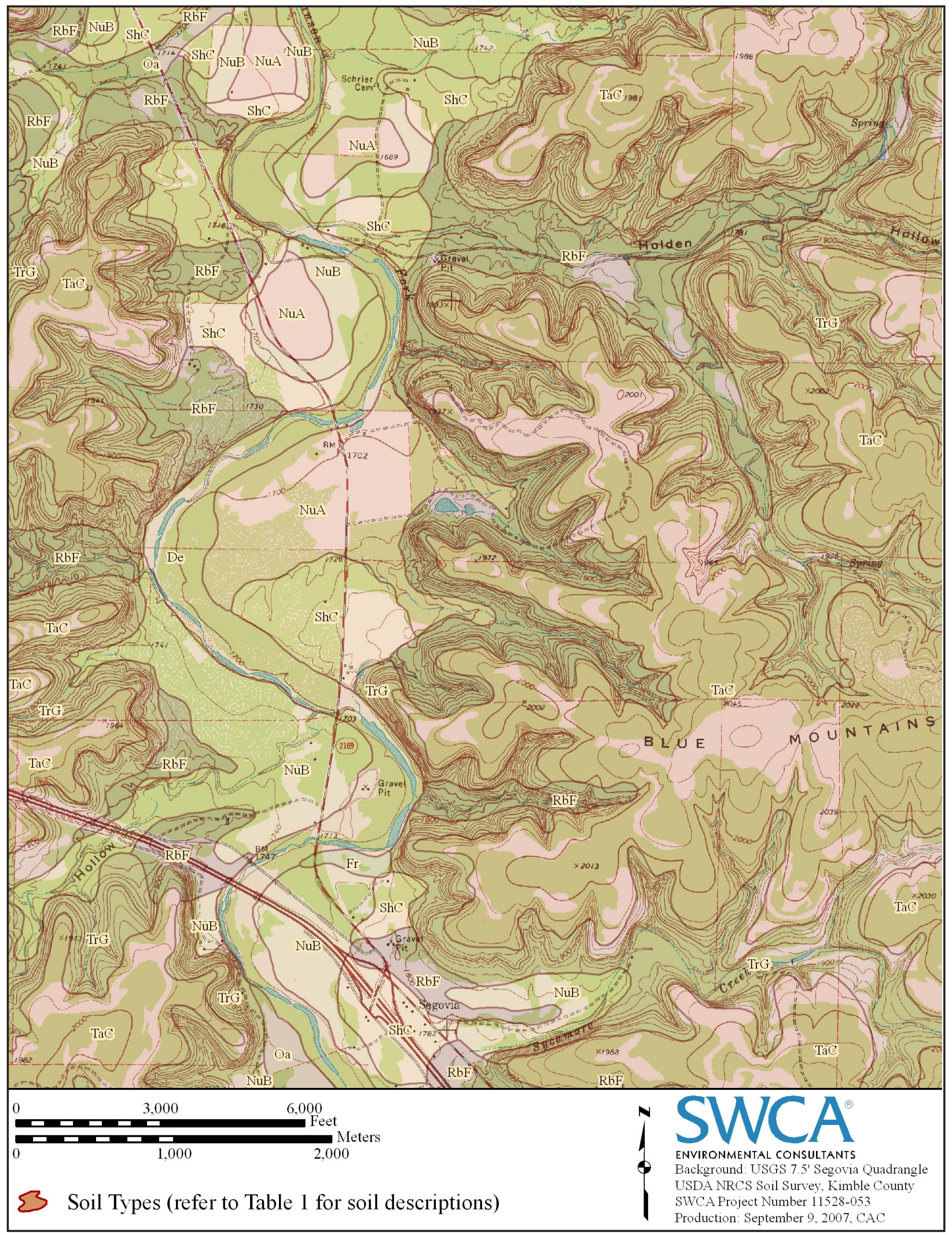

Figure 2.3. Soil types in and around the project area. 
Table 2.1. Soil Descriptions (see Figure 2.3)

\begin{tabular}{|c|c|c|}
\hline Symbol & Soil Name & Soil Description \\
\hline ShC & $\begin{array}{l}\text { Shep clay loam, } 1 \text { to } 5 \text { per- } \\
\text { cent slopes }\end{array}$ & $\begin{array}{l}\text { Occurs on upland foot slopes. Surface layer is brown loam, } 9 \text {-inches thick } \\
\text { and subsoil is light brown clay loam, } 24 \text {-inches thick. The underlying material } \\
\text { is calcareous, moderately alkaline light brown clay loam with accumulations } \\
\text { of calcium carbonate to a depth of } 80 \text {-inches. }\end{array}$ \\
\hline $\operatorname{TrG}$ & $\begin{array}{l}\text { Tarrant-Rock outcrop com- } \\
\text { plex, steep }\end{array}$ & $\begin{array}{l}\text { Occur on upland hills and ridges. Tarrant soils consist of moderatley alka- } \\
\text { line, very dark grayish brown very cobbly clay surface layer, } 5 \text { inches thick } \\
\text { with } 40 \text { percent limestone fragments. Moderately alkaline, dark brown very } \\
\text { cobbly clay with } 65 \text { percent limestone fragments occurs to a depth of } 12 \\
\text { inches. Fractured limestone is below. The Rock outcrop consists of limestone } \\
\text { bedrock exposures on escarpments and ridgetops and along benches on the } \\
\text { sides of ridges. }\end{array}$ \\
\hline NuB & $\begin{array}{l}\text { Nuvalde clay loam, } 1 \text { to } 3 \\
\text { percent slopes }\end{array}$ & $\begin{array}{l}\text { Occurs on upland outwash plains. The surface layer is moderately alkaline } \\
\text { brown clay loam, } 15 \text {-inches thick. The subsoil is brown, moderately alkaline } \\
\text { clay loam from } 15 \text { to } 50 \text { inches. The underlying material is pale brown, mod- } \\
\text { erately alkaline clay loam with accumulations of calcium carbonate, between } \\
50 \text { and } 74 \text { inches. }\end{array}$ \\
\hline $\mathrm{Fr}$ & $\begin{array}{l}\text { Frio silty clay loam, occasion- } \\
\text { ally flooded }\end{array}$ & $\begin{array}{l}\text { Occurs on bottom lands along streams. Moderately alkaline surface layer, } 32 \\
\text { inches thick. The upper part is a dark grayish brown silty clay loam, } 22 \text {-inches } \\
\text { thick and the lower part is brown silty clay. The subsurface layer is moder- } \\
\text { ately alkaline, brown silty clay, } 80 \text {-inches thick. }\end{array}$ \\
\hline $\mathrm{RbF}$ & Real-Brackett complex, hilly & $\begin{array}{l}\text { Occurs on upland ridges and foothills. Real soils consist of surface layer 16- } \\
\text { inches thick, with grayish brown gravelly clay loam upper part 8-inches thick } \\
\text { and a brown very gravelly clay lower part. The underlying layer is weakly } \\
\text { cemented, platy limestone, } 80 \text {-inches thick, that becomes chalky and marly } \\
\text { with depth. Brackett soils consiste of pale brown loam surface layer, 8-inches } \\
\text { thick and moderately alkaline, very pale brown loam, 17-inches thick. The un- } \\
\text { erlying material is very pale brown, interbedded, weakly cemented limestone } \\
\text { fragments with very pale brown clay loam that has rockline structure, to a } \\
\text { depth of } 60 \text { inches. }\end{array}$ \\
\hline $\mathrm{TaC}$ & Tarrant soils, undulating & $\begin{array}{l}\text { Occurs on hills and ridges. The surface layer is calcareous, moderately al- } \\
\text { kaline very cobbly clay, } 16 \text {-inches thick. the upper part is dark grayish brown } \\
\text { with } 50 \text { percent limestone fragments, up to } 7 \text { inches. The lower part is dark } \\
\text { brown with } 75 \text { percent limestone fragments. Fractured limestone bedrock is } \\
\text { below this to a depth of } 22 \text { inches. }\end{array}$ \\
\hline NuA & $\begin{array}{l}\text { Nuvalde clay loam, } 0 \text { to } 1 \\
\text { percent slopes }\end{array}$ & $\begin{array}{l}\text { Occurs on upland outwash plains. Surface layer is } 16 \text {-inches thick with } \\
\text { moderately alkaline, brown clay loam upper part and brown silty clay lower } \\
\text { part. Subsoil is moderate alkaline clay with accumulations of calcium carbon- } \\
\text { ate, } 40 \text {-inches thick. The upper } 14 \text {-inches is brown and the lower part is light } \\
\text { brown. The underlying material is moderately alkaline pink clay loam with } \\
\text { accumultions of calcium carbonate, } 80 \text {-inches thick. }\end{array}$ \\
\hline $\mathrm{Oa}$ & Oakalla silty clay loam & $\begin{array}{l}\text { Occurs on high bottom lands adjacent to large streams. Surface layer is } \\
\text { moderately alkaline sitly clay loam, } 40 \text {-inches thick. The upper part is dark } \\
\text { grayish brown, } 17 \text {-inches thick and the lower part is dark brown. The underly- } \\
\text { ing material is moderately alkaline, grayish brown silty clay loam to a depth } \\
\text { of } 78 \text { inches. }\end{array}$ \\
\hline $\mathrm{De}$ & $\begin{array}{l}\text { Dev very gravelly loam, fre- } \\
\text { quently flooded }\end{array}$ & $\begin{array}{l}\text { Occurs on bottom lands along streams. Dark grayish brown very gravelly } \\
\text { loam, moderately alkaline surface layer, } 26 \text {-inches thick. Moderately alkaline, } \\
\text { brown very gravelly loam subsurface layer, } 72 \text {-inches thick. }\end{array}$ \\
\hline
\end{tabular}




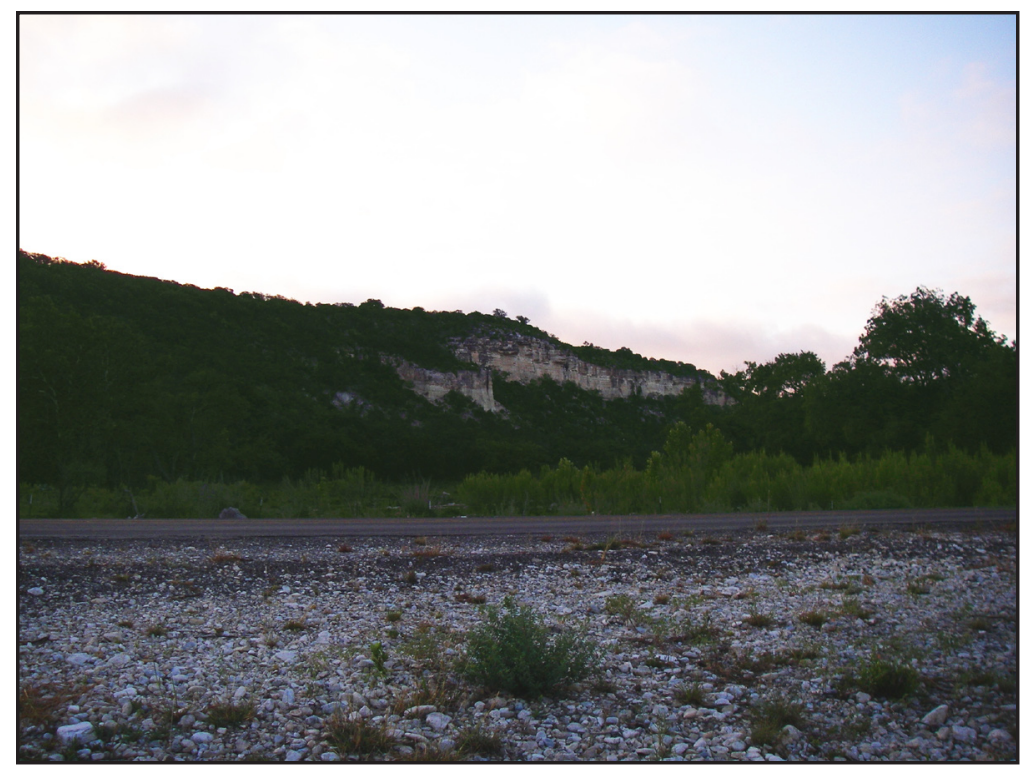

Figure 2.4. Limestone cliff along Johnson Fork southeast of site 41KM225 (facing east).

and buffalograss (Buchloe dactyloides). Other plants commonly found within this vegetational area include agarita (Berberis trifoliolata), ashe juniper (Juniperus ashei), Texas persimmon (Diospyros texana), elbowbush (Forestiera pubescens), Texas mountain laurel (Sophora secundiflora), Spanish moss (Tillandsia usneoides), prickly-pear cactus (Opuntia spp.), claret cup cactus (Echinocereus triglochidatus), and pencil cactus (O. leptocaulis) (Gould 2002; Hatch et. al. 1990; Kutac and Caran 1994; Niehaus et al. 1984; Niering and Olmstead 1990; Petrides and Petrides 1992; Simpson 1988; Stein et al. 2003).

\section{FAUna}

The Balconian biotic province is a transitional zone from the mesic forests of eastern North America to the xeric grasslands of the central United States. Thus, this province has a high faunal diversity. Blair (1950) identified at least 57 species of mammal, over 42 species of reptile, and 15 species of amphibians. None of the fauna for the Balconian is restricted solely to this province (Blair 1950).

Some mammals common to the Balconian province include: coyote (Canis latrans), gray fox (Urocyon cinereoargenteus), mink (Mustela vison), muskrat (Ondata zibethica), raccoon (Procyon lotor), nine-banded armadillo (Dasypus novemcinctus), collared peccary (Dicotyles tajacu), striped skunk (Mephitis mephitis), western spotted skunk (Spilogale gracilis), white-tailed deer (Odocoileus virginianus), opossum (Didelphis virginiana), eastern pipistrel (Pipistrellus subflavus), eastern fox squirrel (Sciurus niger), eastern cottontail rabbit (Sylvilagus floridanus), black-tailed jackrabbit (Lepus californicus), rock squirrel (Spermophilus variegates), pocket gopher (Geomys breviceps), pallid bat (Antrozous pallidus), valley pocket gopher (Thomomys bottae), deer mouse (Peromyscus maniculatis), and badger (Taxidus taxus) (Burt and Grossenheider 1976; Davis and Schmidly 1994; Whitaker 1989). In addition to these common mammals, bison (Bison bison), mountain lions (Felis concolor), and black bear (Ursus americanus) would have been in the area during prehistoric times (Blair 1950).

The general reptilian assemblage for this province include the Great Plains rat snake (Elaphe guttata emoryi), Eastern yellowbelly racer (Coluber constrictor flaviventris), Yellow mud turtle (Kinosternon flavescan flavescan), bullfrog (Rana catesbiana), southern leopard frog (Rana utricularia), and the gulf coast toad (Bufo vallicepus) (Blair 1950; Conant and Collins 1998; Kutac and Caran 1994). 


\section{Paleoenvironment}

Over the past 15,000 years, the environmental and climatic conditions of the Central Texas archaeological region have varied considerably. Although researchers rely on pollen and phytolith studies to reconstruct the paleoenvironment, there are often contradictions between these two sources, as well as the data from different regions and time periods. Combined, most of the data can only indicate a general overview of the paleoenvironmental conditions. Hopefully, as the practice of collecting samples of pollen and phytoliths for paleoenvironmental conditions continues, a more concise and accurate reconstruction can be generated for each archaeological region in the state. Currently, the pollen studies in the Central Texas archaeological region indicate a cool grassland environment was present roughly between 17,000 B.P. and 15,500 B.P. with a trend towards a warmer or more arid climate after 15,000 B.P. (Bousman 1992, 1994, 1998; Camper 1991; Nickels and Mauldin 2001).

After 10,000 B.P., changes in paleoclimatic conditions led to mass extinctions of megafauna across the region (Graham 1987; Graham and Lundelius 1984). Various pollen studies suggest a gradual and consistent warming and drying trend coupled with more seasonal climatic conditions throughout the Early to Middle Holocene (Bousman 1994, 1998; Nickels and Mauldin 2001). Woodland environments were in decline throughout most of the Early to Middle Holocene and stopped around 6,000-5,000 B.P. Arboreal pollen then continued to decline after 5,000 B.P. and slightly increased during a period of a wetter climate (Bousman 1994). This arid interval is also presented by Nordt et al. (1994) from the Applwhite project from 6,000-4,800 B.P. However, Johnson and Goode's (1994) reconstruction of paleoenvironmental conditions do not correlate with Bousman's (1998) pollen based reconstruction dating from
$8,000-6,000$ B.P. and report the arid interval between 5,000-2,500 B.P. Toomey and Stafford (1994) revised interpretation of Hall's Cave in Kerr County indicate the arid episode occurred between 7,000-2,500 B.P. The phytolith analysis at Wilson-Leonard indicates a general expansion of grasslands throughout most of the Holocene beginning around 9,500-4,000 B.P. (Fredlund 1998).

In the Late Holocene, Nordt et al. (1994) indicates a warm and dry period from 3,000-1,500 B.P. and Toomey and Stafford (1994) indicate a wet period around 2,500 B.P. at Hall's Cave. Other studies from the Gulf Coast and Choke Canyon indicate a wetter climate around 3,000 B.P. and 2,450 B.P. respectively (Ricklis 1994; Robinson 1982). Bousman's (1994) grass pollen frequencies indicate drying episodes around $1,600-1,500$ в.P. and 500-400 B.P. 


\section{Chapter 3}

\section{Cultural Setting}

\section{Mindy Bonine}

\section{INTRODUCTION}

Kimble County is located within the Central Texas archaeological region, which extends across the Edwards Plateau and includes portions of the Blackland Prairie and Post Oak Belt (Collins 2004; Prewitt 1981; Turner and Hester 1999). This archaeological region is arbitrarily defined by a combination of physiographic and biogeographic characteristics that are thought to have influenced prehistoric systems of subsistence and settlement. Archaeological investigations in this and other archaeological regions are frequently aimed at identifying broad-scale diachronic changes in the prehistoric record across large geographic zones. This is not to say that these archaeological regions define specific areas where prehistoric communities with common cultural traits are located, as many hunter-forager groups are trans-physiographic by nature, but there are some indications of specific environmentally-based behaviors exhibited in these regions, the Central Texas archaeological region included (i.e., the large quantity of burned rock middens in the region).

\section{Previous Investigations}

Records at TARL indicate that a little over 230 archaeological sites have been recorded in Kimble County as of June 2007. The types of sites found in Kimble County are quite variable, but open campsites with burned rock middens dominate the assemblage (over 25 percent), followed by lithic scatter and procurement sites, mortar holes, rockshelters, and a sinkhole burial. Not many sites are attributable to specific dates of occupation, but at least one site (Red Creek Site; 41KM3) dates to the Late Paleoindian Period, and slightly more than 40 sites (about 19 percent) date to the Archaic Period. Only a few sites are confirmed Late Prehistoric in occupation. Several sites in Kimble County have been investigated beyond the basic recording stage; the majority of these sites are profiled in Chapter 7 and used in a comparative analysis with site $41 \mathrm{KM} 225$.

\section{Prehistoric Cultural History}

The following prehistoric cultural history derives its information from several Central Texas regional chronologies: Black (1989), Collins (2004), Johnson and Goode (1994), which build upon the seminal efforts of Suhm (1960) and Prewitt (1981; 1985). Furthermore, significant archaeological sites within the Central Texas archaeological region have contributed important information to understanding prehistory, including the Richard Beene site at Applewhite Reservoir (McGraw and Hindes 1987; Thoms et al. 1996; Thoms and Mandel 1992), the Cibolo Crossing site at Camp Bullis (Kibler and Scott 2000), the Panther Springs Creek site in Bexar County (Black and McGraw 1985), the Jonas Terrace site in Medina County (Johnson 1995), the Camp Pearl Wheat site in Kerr County (Collins et al. 1990), 41BX1 in Bexar County (Lukowski 1988), 41BX300 in Bexar County (Katz 1987), and several sites at Canyon Reservoir (Johnson et al. 1962).

The following prehistoric cultural sequence is divided into thee periods: Paleoindian, Archaic, and Late Prehistoric. The Historic period follows the Late Prehistoric, announcing the arrival of Europeans to central Texas. The Archaic period is 


\section{3-2 Chapter 3}

subdivided into four subperiods: Early, Middle, Late, and Transitional.

\section{Paleoindian Period}

Human occupation of the Central Texas archaeological region is thought to have begun approximately 11,000 years ago. This period correlates with the end of the late Pleistocene, the last ice age in North America. These early Texans are characterized by small but highly mobile bands of foragers who were specialized hunters of Pleistocene megafauna. But Paleoindians probably used a much wider array of resources (Meltzer and Bever 1995:59), including small fauna and plant foods. Faunal remains from Kincaid Rockshelter and the Wilson-Leonard site (41WM235) support this view (Collins 1998; Collins et al. 1989). Longstanding ideas about Paleoindian technologies also are being challenged.

Surficial and deeply buried sites, rockshelter sites, and isolated artifacts represent Paleoindian occupations in the Central Texas region. Although Paleoindian site types are not well documented within Kimble County, they can be generally classified according to broad site type categories extrapolated from nearby regions. Both open and protected (rockshelter) types are known. Usually these sites are near permanent sources of water such as tributary creeks or springs. Bison kill sites, open and protected campsites, and non-occupation lithic sites are known from the Paleoindian period in Texas. Intra-site features include hearths and isolated burials. The Wilson-Leonard site (41WM235), 41BX52, and 41BX229 contain stratified Paleoindian deposits (Hester 1980). The lower component at the Wilson-Leonard site contained a Paleoindian burial (Collins et al. 1993). The Vera Daniels site (41TV1324), at the confluence of the Colorado River and Barton Creek, has deeply buried deposits which yielded a Plain- view fragment and a possible Clovis preform during limited testing (Ricklis et al. 1991).

Collins (2004) divides the Paleoindian period into early and late subperiods. Two projectile point styles, Clovis and Folsom, are included in the early subperiod. Clovis chipped stone artifact assemblages, including the diagnostic fluted lanceolate Clovis point, were produced by bifacial, flake, and prismatic-blade techniques on high-quality and oftentimes exotic lithic materials (Collins 2004). Along with chipped stone artifacts, Clovis assemblages include engraved stones, bone and ivory points, stone bolas, and ochre (Collins 1995:381; Collins et al. 1992). Clovis points are found evenly distributed along the eastern edge of the Edwards Plateau, where the presence of springs and outcrops of chertbearing limestone are common (Meltzer and Bever 1995:58). Sites within the area yielding Clovis points and Clovis-age materials include Kincaid Rockshelter (Collins et al. 1989), Pavo Real (Henderson and Goode 1991), and San Macros Springs (Takac 1991). Probable Clovis polyhedral blade core and blade fragments were found at the Greenbelt site in San Antonio (Houk et al. 1997b). Analyses of Clovis artifacts and site types suggest that Clovis peoples were well-adapted, generalized hunter-gatherers with the technology to hunt larger game but did not solely rely on it.

In contrast, Folsom tool kits-consisting of fluted Folsom points, thin unfluted (Midland) points, large thin bifaces, and end scrapers - are more indicative of specialized hunting, particularly of bison (Collins 1995:382). Folsom points have been recovered from Kincaid Rockshelter (Collins et al. 1989) and Pavo Real (Henderson and Goode 1991).

Postdating Clovis and Folsom points in the archeological record are a series of dart point styles (primarily unfluted lanceolate darts) for which the temporal, technological, or cultural 
significance is unclear. Often, the Plainview type name is assigned to these dart points, but Collins (1995:382) has noted that many of these points typed as Plainview do not parallel Plainview type-site points in thinness and flaking technology. Recent investigations at the WilsonLeonard site (Bousman 1998) and a statistical analysis of a large sample of unfluted lanceolate points by Kerr and Dial (1998) have shed some light on this issue. At Wilson-Leonard, the Paleoindian projectile point sequence includes an expanding-stem dart point termed Wilson, which dates to ca. $10,000-9,500$ B.P. Postdating the Wilson component is a series of unfluted lanceolate points referred to as Golondrina-Barber, St. Mary's Hall, and Angostura, but their chronological sequence is poorly understood. Nonetheless, it has become clear that the artifact and feature assemblages of the later Paleoindian subperiod appear to be Archaic-like in nature and in many ways may represent a transition between the early Paleoindian and succeeding Archaic periods (Collins 1995:382).

\section{Archaic Period}

The Archaic period for the Central Texas archaeological region dates from ca. 8,800 to $1,300-1,200$ в.P. (Collins 2004) and has generally been believed to represent a shift toward hunting and gathering of a wider array of animal and plant resources and a decrease in group mobility (Willey and Phillips 1958:107-108). In the eastern and southwestern United States and on the Great Plains, development of horticulturalbased, semi-sedentary to sedentary societies succeeded the Archaic period. In these areas, the Archaic truly represents a developmental stage of adaptation as Willey and Phillips (1958) define it. For central Texas, this notion of the Archaic is somewhat problematic. An increasing amount of evidence suggests that Archaic-like adaptations were in place before the Archaic (Collins 1995:381-382, 1998; Collins et al. 1989) and that these practices continued into the succeeding Late Prehistoric period (Collins 1995:385; Prewitt 1981:74). In a real sense, the Archaic period of Central Texas is not a developmental stage, but an arbitrary chronological construct and projectile point style sequence. Establishment of this sequence is based on several decades of archaeological investigations at stratified Archaic sites along the eastern and southern margins of the Edwards Plateau. Collins (2004) and Johnson and Goode (1994) have divided this sequence into three parts - early, middle, and late - based on perceived (though not fully agreed upon by all scholars) technological, environmental, and adaptive changes. However, Turner and Hester (1999) and Black (1989) have designated another period at the end of the Archaic, referred to as Transitional Archaic or Terminal Archaic.

\section{Early Archaic}

The Early Archaic period (8,800-6,000 в.Р.) is better documented than the Paleoindian period, however a complete understanding of cultural patterns does not yet exist. Early Archaic sites are small, and their tool assemblages are diverse (Weir 1976:115-122), suggesting that populations were highly mobile and densities low (Prewitt 1985:217). It has been noted that Early Archaic sites are concentrated along the eastern and southern margins of the Edwards Plateau (Johnson and Goode 1994; McKinney 1981). This distribution may indicate climatic conditions at the time, given that these environments have more reliable water sources and a more diverse resource base than other parts of the region.

Artifact assemblages of the Early Archaic include projectile points styles such as Hoxie, Bulverde, Gower, Wells, Martindale, and Uvalde, as well as early split stem projectile points. A variety of choppers and gouges, such as the triangular, concave based bifaces known as Guadalupe tools, and the distally beveled Clear Fork uni- 
faces are present in the archeological record. A variety of expediency tools, often nothing more than utilized flakes, are increasingly present in the Early Archaic (Black 1989).

The construction and use of rock hearths and ovens, which had been limited during the Paleoindian period, become commonplace in the Early Archaic. The use of rock features suggests that retaining heat and releasing it slowly over an extended period were important in food processing and cooking and reflects a specialized subsistence strategy. Such a practice probably was related to cooking plant foods, particularly roots and bulbs, many of which must be subjected to prolonged periods of cooking to render them consumable and digestible (Black et al. 1997:257; Wandsnider 1997; Wilson 1930). Botanical remains, as well as other organic materials, are often poorly preserved in Early Archaic sites, so the range of plant foods exploited and their level of importance in the overall subsistence strategy are poorly understood. But recovery of charred wild hyacinth (Camassia scilloides) bulbs from an Early Archaic feature at the Wilson-Leonard site provides some insights into the types of plant foods used and their importance in the Early Archaic diet (Collins et al. 1998).

Significant Early Archaic sites include the Richard Beene site in Bexar County (Thoms and Mandel 1992), the Camp Pearl Wheat site in Kerr County (Collins et al. 1990), and the Jetta Court site in Travis County (Wesolowsky et al. 1976).

\section{Middle Archaic}

Cultural patterns during the Middle Archaic period (6,000-4,000 B.P.), point toward an increased sedentary population intensively harvesting acorns, Yucca "tuna", and pecans, and hunting small and medium-size game such as deer and turkey. The increase in the number of Middle
Archaic sites and burials supports the concept of a larger, more sedentary population (Black and McGraw 1985; Prewitt 1981:73; Weir 1976:124, 135). Large bands may have formed at least seasonally to occupy a single area, or small groups may have used the same sites for longer periods (Weir 1976:130-131).

Sites of the Middle Archaic are numerous and often large in size. Burned rock middens are found at many sites with Middle and Late Archaic components in the Central Texas archaeological region. The development of burned rock middens toward the end of the Middle Archaic suggests a greater reliance on plant foods, although tool kits still imply a considerable dependence on hunting (Prewitt 1985:222-226). Middle Archaic projectile point styles include Bell, Andice, Calf Creek, Taylor, Nolan, and Travis. Other artifacts from the Middle Archaic are choppers, gouges, and expediency tools such as the small, bifacial and unifacial Clear Fork tools. Grinding stones and bases, referred to as manos and metates, show up in Middle Archaic artifact assemblages as well as a number of perforators, drills and awls. Chipped, polished, and ground stone artifacts are common in central Texas and surrounding regions. Less frequently encountered artifacts include tools and ornaments of bone, antler, and marine shell (Turner and Hester 1999).

Bell and Andice points reflect a shift in lithic technology from the preceding Early Archaic Martindale and Uvalde point styles (Collins 1995:384). Johnson and Goode (1994:25) suggest that the Bell and Andice darts are parts of a specialized bison-hunting tool kit. They also believe that an influx of bison and bison-hunting groups from the Eastern Woodland margins during a slightly more mesic period marked the beginning of the Middle Archaic. Though no bison remains were recovered, Bell and Andice points and associated radiocarbon ages were recovered from the Cibolo Crossing (Kibler and Scott 2000), Panther Springs Creek, and 
Granberg II (Black and McGraw 1985) sites in Bexar County.

Bison populations disappeared as more-xeric conditions returned during the later part of the Middle Archaic. Later Middle Archaic projectile point styles (Nolan and Travis) represent another shift in lithic technology (Collins 1995:384; Johnson and Goode 1994:27). At the same time, this shift to drier conditions saw the burned rock middens develop, probably because intensified use of geophytic or xerophytic plants meant the debris from multiple rock ovens and hearths accumulated as middens on stable to slowly aggrading surfaces, as Kelley and Campbell (1942) suggested many years ago. Johnson and Goode (1994:26) believe that the dry conditions promoted the spread of yuccas and sotols, and that it was these plants that Middle Archaic peoples collected and cooked in large rock ovens.

\section{Late Archaic}

During the succeeding Late Archaic period (4,000 to 1,300-1,200 B.P.), populations continued to increase (Prewitt 1985:217). As evidenced by stratified Archaic sites such as Loeve-Fox, Cibolo Crossing, and Panther Springs Creek, the Late Archaic components contain the densest concentrations of cultural materials of all these periods. Establishment of large cemeteries along drainages also suggests certain groups had strong territorial ties (Story 1985:40).

Middle Archaic subsistence technology, including the use of rock and earth ovens, continues into the Late Archaic period. Collins (1995:384) states that, at the beginning of the Late Archaic period, the use of rock ovens and the resultant formation of burned rock middens reached its zenith and that the use of rock and earth ovens declined during the latter half of the Late Archaic. There is, however, mounting chronological data that midden formation culminated much later and that this high level of rock and earth oven use continued into the early Late Prehistoric period (Black et al. 1997:270-284; Kleinbach et al. 1995:795). A picture of prevalent burned rock midden development in the eastern part of the Central Texas archaeological region after 2,000 B.P. is gradually becoming clear. This scenario parallels the widely recognized occurrence of post-2,000 B.P. middens in the western reaches of the Edwards Plateau (Goode 1991).

The use of rock and earth ovens (and the formation of burned rock middens) for processing and cooking plant foods suggests that this technology was part of a generalized foraging strategy. Considering the amount of energy involved in collecting plants, constructing hot rock cooking appliances, and gathering fuel, the caloric return of most plant foods is relatively low (Dering 1999). This suggests that plant foods were part of a broad-based diet (Kibler and Scott 2000:134) or part of a generalized foraging strategy, an idea Prewitt (1981) put forth earlier. At times during the Late Archaic, this generalized foraging strategy appears to have been marked by shifts to a specialized economy focused on bison hunting (Kibler and Scott 2000:125-137). Castroville, Montell, and Marcos dart points are elements of tool kits often associated with bison hunting (Collins 1968). Archaeological evidence of this association is seen at Bonfire Shelter in Val Verde County (Dibble and Lorrain 1968), Jonas Terrace in Medina County (Johnson 1995), Oblate Rockshelter (Johnson et al. 1962:116), John Ischy in Williamson County (Sorrow 1969), and Panther Springs Creek (Black and McGraw 1985).

\section{Transitional Archaic}

As Collins (1995:384-385) notes, diverse and comparatively complex archaeological manifestations toward the end of the Late Archaic attest to the emergence of kinds of human conduct without precedent in the area. This period $(2,250-1,250$ в.P.), referred to as the Transitional 
Archaic (Turner and Hester 1999) or Terminal Archaic (Black 1989), is not recognized by all researchers. Other chronologies terminate the Late Archaic at around 1,200-1,250 B.P. (Collins 2004; Johnson and Goode 1994) to encompass this later subperiod. Johnson et al. (1962) originally designated the Transitional Archaic as a subperiod of the Archaic because of the similarities between the latest dart point types and the earliest arrow point types. Since then, however, the designation has failed to be universally accepted by researchers. In two recent chronologies for central Texas, Collins (2004) does not include the Transitional as a subperiod of the Archaic, and Johnson and Goode (1994) separate the Late Archaic into two subperiods designated Late Archaic I and Late Archaic II. The Transitional Archaic, as it is used here, closely corresponds to Johnson and Goode's (1994) Late Archaic II, but begins after the appearance of Marcos points, not with it. In this scheme, the Transitional Archaic coincides with the last two style intervals recognized by Collins (2004) (Figure 3.1) for the Late Archaic subperiod.

During the Transitional Archaic, smaller dart point forms such as Darl, Ensor, Fairland, and Frio were developed (Turner and Hester 1999). These points were probably ancestral to the first Late Prehistoric arrow point types and may have overlapped temporally with them (Hester 1995; Houk and Lohse 1993).

Several researchers believe that the increased interaction between groups at the end of the Late Archaic was an important catalyst for cultural change (Collins 2004; Johnson and Goode 1994). This change may have included increased regional stress and conflict between groups as interaction became more frequent (Houk, et al. 1997a). In Bexar County, for instance, researchers noted a distinct shift in settlement patterns during this period (Houk, et al. 1997a). Groups began to use hilltops as camps rather than just lithic procurement locations. These elevated locations would have provided points from which to observe game and other groups of humans as they moved through the surrounding creek valleys and upland prairies (Houk, et al. 1997a).

Overall, the Archaic period represents a hunting and gathering way of life that was successful and remained virtually unchanged for more than 7,500 years. This notion is based in part on fairly consistent artifact and tool assemblages through time and place and on resource patches that were used continually for several millennia, as the formation of burned rock middens show. This pattern of generalized foraging, though marked by brief shifts to a heavy reliance on bison, continued almost unchanged into the succeeding Late Prehistoric period.

\section{Late Prehistoric Period}

Introduction of the bow and arrow and, later, ceramics into the Central Texas archaeological region marks the Late Prehistoric period (1,250-350 в.P.). Population densities dropped considerably from their Late Archaic peak (Prewitt 1985:217). Subsistence strategies did not differ greatly from the preceding period, although bison again became an important economic resource during the latter part of the Late Prehistoric period (Prewitt 1981:74). Use of rock and earth ovens for plant food processing and the subsequent development of burned rock middens continued throughout the Late Prehistoric period (Black et al. 1997; Kleinbach et al. 1995:795). Horticulture came into play very late in the region but was of seemingly minor importance to overall subsistence strategies (Collins 1995:385).

Artifact assemblages include Scallorn, Perdiz, and Edwards projectile points, worked stone, thermally altered stone, hematite, bone, and shell. The points are associated with the use of 




Figure 3.1. Central Texas Chronology. 
the bow and arrow in the region, probably introduced sometime around 1,350-1,150 B.P.

The earlier Austin phase (identified by Scallorn and Edwards points) and the later Toyah phase (defined through Perdiz points) divide the Late Prehistoric period throughout central Texas (Black 1989; Story 1990). These divisions were originally recognized by Suhm (1960) and Jelks (1962), and remain an accepted separation of the period. Although a distinct change in the material culture between the two phases can be seen in the archaeological record, there is some debate over the cultural underpinnings that prompted the change. The different arrow point styles (and other associated artifacts in the assemblage) may represent distinct cultural groups (Johnson 1994), but others challenge this view (e.g., Black and Creel 1997), and attribute the change to a spread of new technological ideas in response to the increase of a different economic resource in bison populations (Ricklis 1992). Nevertheless, prehistoric communities traced through cultural remains assigned to the Austin phase (1,250-650 B.P.), like many of the Archaic period cultures before them, relied on a hunting and gathering subsistence with more of an emphasis on gathering (Prewitt 1981:83). Communities attributed to the Toyah phase (650-200 B.P.) relied more on bison procurement (Prewitt 1981:84).

Around 1,000-750 B.P., slightly more-xeric or drought-prone climatic conditions returned to the region, and bison came back in large numbers (Huebner 1991; Toomey et al. 1993). Using this vast resource, Toyah peoples were equipped with Perdiz point-tipped arrows, end scrapers, four-beveled-edge knives, and plain bone-tempered ceramics. Toyah technology and subsistence strategies represent a completely different tradition from the preceding Austin phase. Collins (1995:388) states that formation of burned rock middens ceased as bison hunting and group mobility obtained a level of importance not witnessed since Folsom times. Although the importance of bison hunting and high group mobility hardly can be disputed, the argument that burned rock midden development ceased during the Toyah phase is tenuous. A recent examination of Toyah-age radiocarbon assays and assemblages by Black et al. (1997) suggests that their association with burned rock middens represents more than a "thin veneer" capping Archaic-age features. Black et al. (1997) claim that burned rock midden formations, although not as prevalent as in earlier periods, was part of the adaptive strategies of Toyah peoples.

\section{Historic Culture History}

The Historic period (A.D. 1630 to present) in Texas roughly begins when Europeans first entered the region. From just after A.D. 1550 to the late $1600 \mathrm{~s}$, European journeys into the area were rare. Motivated primarily by European politics, the first Europeans into the project area were probably Spanish explorers and missionaries (Foster 1995). With the exception of these Spanish expeditions or entradas, Texas during the early Historic Period was claimed by Spain but basically remained without an established Spanish presence until around A.D. 1700 (Foster 1995; Taylor 1996).

\section{SPANISH COLONIAL/MEXICAN INDEPENDENCE PERIOD (1630-1820S)}

The Spanish Colonial period (A.D. 1630-1821) may be characterized as the initial period of $\mathrm{Ab}$ original/European contact and European settlement in Texas. During this time Kimble County was inhabited by several aboriginal groups including the Comanche, Kiowa, Apache, and Lipan Apache (Thompson 2007). Motivated more by a fear of French expansion than anything else, the Spanish explored and established missions in eastern and central Texas during the latter part of the seventeenth century (Foster 1995). These early overland Spanish entradas utilized 
established Indian trade routes, with the first being led by Governor Alonso de Léon (1689 and 1690) (Foster 1995). José de Urrutia passed through the area of present Kimble County as the leader of a Spanish campaign against Apaches in 1739. In 1754, Pedro de Rabago y Teran passed through on his way to the lands surrounding the San Saba River. Other early Spaniards in the area included Diego Ortiz Parrilla, who led a campaign against the Apaches in 1759, and the Marques de Rubi, who led an inspection of the northern Frontier of New Spain in 1767 (Thompson 2007). In 1808, Capt. Francisco Amangual commanded a military expedition from San Antonio to Santa Fe and mapped a road which passed through what is now Kimble County. The expedition was intended as a show of strength to the Plains Indians.

\section{Republic of Texas/Pre-CiVIL War (1836-1860)}

During the Republic of Texas era, from 18361845 , the Kimble County area remained an Indian stronghold until the 1870s. Kimble County was first mentioned in Republic of Texas documents in 1842, when 416,000 acres of the present county were included in the Fisher-Miller Land Grant, which extended from the Llano River to the Colorado River (Thompson 2007).

On December 29, 1845, Congress signed the Texas Admission Act, the result of several years of annexation debate. A few months later on February 19, members of the newly formed state government conducted a ceremony in front of the Capitol at Austin marking Texas' official annexation into the Union and the end of the Republic of Texas (Campbell 2003:186; Miller and Faux 1997:78).

In 1851, Captain Henry E. McCulloch commanded a Texas Ranger post near the center of the present Kimb e County. Fort Terrett, a fron- tier post, operated in the area from November 1852 to September 1853, when it was abandoned due to the lack of inhabitants or Indians in the region. The earliest white settlers settled on Bear Creek in the late 1850s. In 1858, Kimble County was formed by the Texas legislature from lands assigned to Bexar County and was attached to Gillespie County for judicial purposes (Thompson 2007).

\section{The Post-CiVIL War/Reconstruction PERIOD (1865-1880)}

Following the Civil War permanent settlements arose for the first time near Johnson Fork of the Llano River, Copperas Creek, and in the valleys of the James River. The first store in Kimble County was built in 1873 at Johnson Fork and was supplied by goods from Kerrville (Thompson 2007). Comanche raided the settlements frequently until General Ranald S. Mackenzie drove them onto reservations and killed their horses in 1874 and 1875 . The Lipan and Kickapoo continued to make raids into Kimble County, but the last serious raid took place in 1876 (Thompson 2007).

In 1876, the towns of Kimbleville and Junction were founded, and Kimbleville was elected the county seat. However, for some undocumented reason (although perhaps because Kimbleville was located in a flood-prone area), following the first district court session Junction became the county seat. Kimbleville was soon depopulated and the first post office in the county opened in Junction in 1877 (Thompson 2007). The population of Kimble County increased steadily from 72 in 1870 to 1,343 in 1880 ; by $1890,2,243$ people lived in the area (Thompson 2007). 


\section{LATE NineteENTH/EARLY TWENTIETH CENTURY (1880-1940s)}

Due to the hilly topography of Kimble County, the land was more suitable for ranching than farming, the raising of cattle and sheep soon dominated the economy. By 1890, the census reported 279 farms and ranches encompassing over 470,000 acres; 38,988 cattle and 120,574 sheep were counted that year (Thompson 2007). By 1900, the number of farms and ranches in the area had dropped slightly, as well as the numbers of cattle reported in the area, but sheep herding was significantly reduced. Alternatively, it appeared that county residents turned their attention to farming, and corn, wheat, and cotton increased in production. By 1910, there were 415 farms and ranches in the county, cotton production had expanded to almost 3,000 acres, and the population had grown to 3,261 (Thompson 2007).

The early part of the twentieth century brought several changes. Junction and Kimble County gained a reputation as a tourist and hunting area beginning in the 1920s, with Junction serving as the chief commercial shipping center for the county. Sheep made a comeback at this time, and goats, introduced into the area at the turn of the century, numbered almost 160,000 by 1920. By the end of the 1920s Kimble County was one of the leaders in the state's wool and mohair industry (Thompson 2007).

The entire county suffered through the Great Depression like much of the country, but many inhabitants managed to keep their farms and the county was recovering by 1940 . During the mid1940s a small amount of oil was produced, which along with a small production of sand, gravel, and gas constituted a new industry for the area. By the late 1940s all of Kimble County's highways had been paved. Old highways 4 and 27 became U.S. Highway 83, Highway 27 became U.S. 290, and Highway 29 became U.S. 377.
Kimble County remains primarily agricultural, with 744,000 acres, or 91.2 percent of its total area used for agriculture (Thompson 2007). 


\title{
Chapter 4
}

\section{Methods and Research Design}

\author{
Mindy Bonine and Michael Chavez
}

\section{INTRODUCTION}

The portions of site 41KM225 that would be impacted by the proposed undertaking were recommended for testing shortly after the site's discovery in order to determine the integrity and information potential of the archaeological deposits. As such, SWCA was tasked with developing a research design, methodology, and scope of work for significance testing at site $41 \mathrm{KM} 225$ that would determine if the site was considered eligible under Criterion D of the NRHP or for listing as an SAL. The research design was based around general research issues given that very little was known about the site prior to testing, and the methodology and scope of work were designed to obtain the best information possible given the limitations of the site setting and land access constraints. As the explanation of the methodology and scope of work will be better understood within the context of the site setting, a brief discussion is presented below.

\section{Site Setting}

Site $41 \mathrm{KM} 225$ is approximately $7.9 \mathrm{~km}(4.92$ miles) south of the confluence of Johnson Fork and the Llano River. It is located north of Johnson Fork at its middle crossing with FM 2169, approximately $2.2 \mathrm{~km}$ (1.37 miles) north of IH-10 at Segovia. The site sits on the southern edge of a large toe slope of the Blue Mountains, which has been incised by FM 2169. The remains of site $41 \mathrm{KM} 225$ can be seen in the cutbanks and ground surface within the ROW on both sites of the road and extend for a distance of approximately $110 \mathrm{~m}$.
The portion of the site east of the roadway sits on a narrow flat portion of the toe slope, just beneath a steep rise in elevation leading to the Blue Mountains. This part of the eastern area sits at the same general elevation as the investigated portions of the site on the west side of the road. A cedar oil processing mill is located in the same area just beyond the ROW, and the construction of the mill appears to have modified the original ground surface (Figure 4.1). Aerial photographs reveal extensive disturbances to the area beyond the ROW from the oil processing mill. Between the roadway and the fence designating the edge of the ROW, a burned rock midden was seen in the cutbank, which would later be designated Feature 1.

The area of the site west of the roadway has been incised by a small upland drainage, fed by a culvert under FM 2169, leading westward to Johnson Fork, isolating a portion of the toe slope. The drainage on the western side of the ROW does not extend into the eastern portion of the ROW. A small "hill" has been created between the drainage to the north, FM 2169 to the east, and a wetland and floodplain to the south. This isolated portion of the toe slope, with the appearance of a small hill, is the location where the majority of the subsurface archaeological investigations occurred (Figure 4.2). The hill sits approximately 12 $m$ above Johnson Fork to the south and $3 \mathrm{~m}$ above the upland drainage to the north.

\section{Testing Research Design}

With so little known about the site prior to testing, SWCA developed a broad research design with 


\section{Restricted}

\section{Contains Site Information}

Figure 4.1. Location of site 41KM225, the small intermittant drainage, and the isolated "hill" where most of the archaeological work was conducted. 




Figure 4.2. View of site 41KM225, looking north. Note that FM 2169 incises the terrace where the site is located, and separates the west side (with the small "hill") and the east side (with the cedar oil processing mill).

few expectations about the nature of the site or its components. The project's stated goals were to systematically identify, record, and assess the significance of archaeological materials discovered at 41KM225. Levels of artifactual and contextual integrity, chronology, potential data yield, and preservation potential were key criteria in this evaluation. The investigations focused on two main issues: integrity and potential data yield.

\section{RESEARCH ISSUE 1: INTEGRITY OF THE ARChaEological Deposits}

A primary factor in determining the significance of site 41KM225 was the integrity of its archaeological deposits. One goal of these investigations was to acquire data on depositional context, define any relationships between natural strata and subsurface cultural features/deposits, and determine if the integrity of the buried deposits is sufficient to establish relative and/or absolute chronological dates for any subsurface components and to subdivide recovered materials into analytical units relevant to specific research questions. Therefore, excavations were performed with sufficient detail and observations to provide for the identification and documentation of relevant analytical units. Radiocarbon samples were collected for analysis to establish a chronology for the components at the site and to evaluate integrity (i.e., are the deposits compressed, are they mixed, are they stratified?).

\section{Research Issue 2: Potential DATA YIELD}

A secondary factor in determining the significance of the site was the potential for additional excavations to recover meaningful quantities of data, both in terms of artifacts and other special samples that could be used to address specific research questions related to one or more historic contexts during data recovery. At this stage in the process, with so little known about the site, proposing detailed research questions was premature. Thus, general questions, which would be relevant to any archaeological investigation, were addressed by the testing project, including site size, function, and chronology. Preservation potential for macrobotanical or faunal remains was also a criterion used to evaluate potential data yield. Macrobotanical samples were collected from feature contexts to provide for future analysis, if appropriate.

\section{EVALUATING SigNificanCE}

Prior to testing, SWCA proposed that for the site to be found significant under Criterion $\mathrm{D}$, the deposits must demonstrate sufficient integrity and data yield potential to address specific, detailed research questions that would contribute to the understanding of the regional prehistory within the framework of one or more 
historic contexts. If the site had good integrity but a stratigraphically dispersed, low density of artifacts, no dateable materials, no features, and poor preservation of organics, it would be less likely to contribute new or important information. Similarly, if the site had abundant artifacts and materials but poor archaeological integrity, eligibility would be contraindicated. In either case, site eligibility hinged on its ability to address one or more explicit, non-trivial questions about prehistory.

\section{SCOPE OF WorK}

The methodology and scope of work were designed to provide the information necessary to address the research issues described above and make a determination as to site 41KM225's integrity and information potential. As the proposed undertaking would not affect any portions of the site outside of the TxDOT ROW, all significance testing was conducted within the 100-foot ROW of FM 2169.

\section{Texas Antiquities Permit Application}

As the initial step in the investigation, SWCA completed a Texas Antiquities Permit application to conduct the fieldwork for the project. As part of this task, SWCA completed a preliminary scope of work that addressed artifact collection, site mapping, feature documentation, and special samples. An interim report was planned that would provide a summary of the excavations, stratigraphy, integrity, and recovered materials, and would make recommendations for additional work, if any. The final report would include a description of the field and analytical methodologies that were used, provide background cultural and environmental settings, detail the results of laboratory analyses, and include a discussion of the site within a larger prehistoric context.

\section{Archaeological Testing}

SWCA's testing investigations were designed with two information gathering techniques: 1) hand shovel testing to define the horizontal site boundaries within the TxDOT ROW, and 2) hand excavation units to establish the vertical site limits within the TxDOT ROW and determine the research potential of the cultural deposits at $41 \mathrm{KM} 225$. Due to the limited area for which to conduct the testing excavations and the vertical profiles provided by the cutbanks on either side of FM 2169, no backhoe trenching was conducted at the site. The portion of the site west of FM 2169 was the focus on the investigations, having more intact deposits, but the portion on the east side of the roadway was also investigated.

Shovel tests were approximately $30 \mathrm{~cm}$ in diameter and excavated in arbitrary $20-\mathrm{cm}$ levels to $100 \mathrm{cmbs}$ or culturally sterile deposits, whichever came first. The matrix from each shovel test was screened through 1/4-inch hardware mesh, and the location of each excavation was plotted using a hand-held GPS receiver and a digital theodolite, if possible. Each shovel test was recorded on a standardized form to document the excavations.

A minimum of $3 \mathrm{~m}^{3}$ of hand excavations were allocated according to the Principal Investigator and Project Archaeologist's professional judgment. Hand excavation units focused on the 4-5-m wide, 40-m long strip of ROW on the western side of FM 2169 where TxDOT (Arnn and Abbott 2006) observed cultural materials in intact deposits. The $3 \mathrm{~m}^{3}$ were divided among six 1-x-1-m test units, which were excavated to $1 \mathrm{~m}$ deep or to sterile deposits. Using standard archaeological methods, excavation units were systematically excavated in arbitrary $10-\mathrm{cm}$ levels and documented using standardized field forms and photographs. All soils were screened through $1 / 4$-inch hardware mesh. 
Since the known feature at the site was heavily disturbed and no room remained between the fenceline and the cutbank to safely place a 1-x1 -m test unit at its location, it was investigated differently than if it had been encountered in a test unit. The feature was numbered, exposed in profile, drawn, and photographed. The remaining intact portions of the feature were documented through profile analysis and shovel testing, also a small soil sample was collected. The feature material recovered from the shovel tests were thoroughly documented, including the types, counts, and characteristics of the burned rock material and surrounding matrix. No other features were located during the testing investigations.

\section{SITE MAPPING}

The locations of all excavations and features at site 41KM225 were carefully mapped using a digital theodolite during the testing project. The excavations and site boundaries were mapped in relation to existing roadway limits, modern construction features, the existing topography, and natural features including Johnson Fork. An arbitrary vertical datum with an elevation of 100 $\mathrm{m}$ was established at the site and all subsequent measurements were based off this elevation. Given the fact that the site was incised by an operating roadway, a grid was not established. The horizontal placement of the hand excavation units was based on topography and anticipation of intact deposits, and they were oriented on a line following magnetic north (and parallel to FM 2169).

\section{Artifact Collection and Special SAMPLES}

All artifacts recovered from each provenience unit were collected, bagged, and labeled accordingly. Burned rock was quantified (by size category), counted, and weighed in the field, but not collected unless for the purposes of special sample analysis. Special samples were systematically collected from appropriate contexts across the site. Special samples include materials for radiocarbon dating (from features, geomorphic units, and other appropriate contexts, with AMS dating used when necessary), and matrix samples for flotation and/or fine screening (from the feature). Appropriate conditions for the acquisition of pollen/phytolith samples to aid in paleoenvironmental reconstruction and burned rock samples for lipid residue analysis were not observed, and thus no such samples were collected. 



\section{Chapter 5}

\section{RESULTS OF INVESTIGATION}

Mindy Bonine and Michael Chavez

\section{INTRODUCTION}

This chapter summarizes the results of the testing investigations, including a description of the daily chronology of excavations, a summary of the level of effort, a discussion of the site size and natural stratigraphy, and an account of the cultural components, including a description of Feature 1.

\section{Narration ANd Summary OF THE Excavations}

In Chapter 4, a description of the methodology and scope of work was presented, which was based on what was known about the site before the testing investigations were conducted. Below is a description of how that scope of work was carried out, and describes the progress of the investigations day-by-day as well as any changes to the scope that were necessary based on the realities of the situation.

\section{Chronology of EVENTS}

SWCA began testing on July 24, 2006. Upon arrival to the site, the portion of the site on the western side of FM 2169 was found to be primarily located on the top of a "hill" formed by the floodplain of Johnson Fork to the south and a steep drainage to the north (Figure 5.1). Several lithic flakes and small burned limestone rocks were seen on the ground surface across the top of the hill. Based on the angle of the drainage to the west and a review of aerial photographs, it appears to connect with the floodplain of Johnson Fork somewhere on private property west of the ROW (see Figure 4.1). The portion of the site on the east side of FM 2169 could be seen eroding out of the road cut, and the dark ashy soil and burned limestone were relocated towards the southern edge of the road cut.

Before the 1-x-1-m test excavation units were positioned, two shovel tests (STs 1 and 2) were placed north of the hill on the west side of the road, to see if the site extended in that direction. As the creek floodplain and wetlands were observed to the south on both sides of the road, and the entrance to the cedar oil processing mill was north of the site on the east side of the road (destroying any cultural material located there), no shovel tests were placed in those locations. Cultural material was recovered

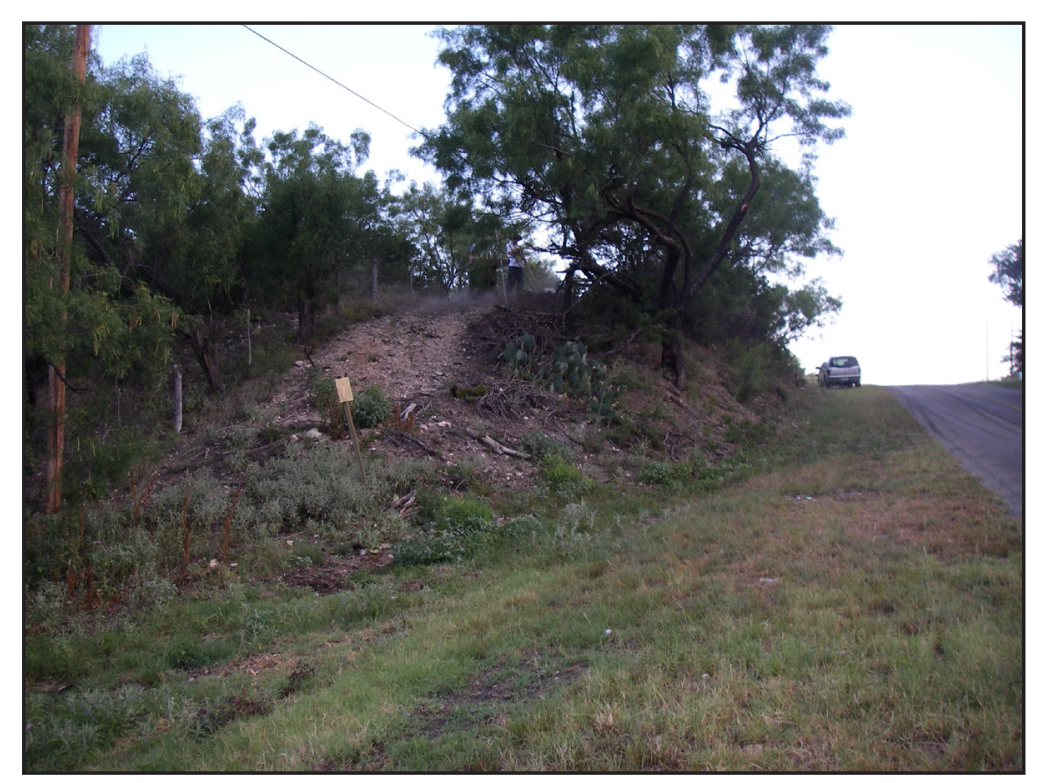

Figure 5.1. Close-up of the isolated "hill" formed by FM 2169, an intermittent drainage, and the floodplain of Johnson Fork (facing north). 


\section{5-2 Chapter 5}

from one shovel test, but both of the shovel tests revealed extremely shallow soils. These soils would not provide a suitable stratigraphic context in which to observe deposits of cultural material, and it was decided that no 1-x-1-m test excavation units would be placed to the north of the drainage area. As the hilltop represented the deepest soil deposition, all of the test excavation units were placed there.

The transit was set up at the south end of the hilltop on the west side of the road, and the 100 $\mathrm{m}$ arbitrary datum was placed at the topmost part of the hill near the road cut. Next, three 1-x-1-m test excavation units were set up along the most level portions of the hill (Figure 5.2). The top of the hill had been previously cleared of vegetation under the powerline running parallel to the roadway within the ROW, and ashy surface soil stains were visible in the cleared area (Figure 5.3). The stains appeared at the western edge of the ROW on the hilltop, extending into the project area about $1.5 \mathrm{~m}$ away from the fenceline.

Just before the screen tripods were set up and excavations began, the ground surface was visually inspected for surface level artifacts. Modified flakes, tools, and projectile points were all piece-plotted, given a field specimen (FS) number, and collected. The northernmost test excavation unit (TU 1) was positioned about $1 \mathrm{~m}$ away from the ROW fence, just at the point where the hill flattens out, and aligned to magnetic north. The test excavation unit was positioned partially within the ashy soil stain visible on the ground surface. The middle test excavation unit (TU 2) was placed 3 m away from the fenceline at the highest point on the hill and oriented to magnetic north. The southernmost test excavation unit (TU 3) was situated on a flat portion of the hill just before it slopes down towards the wetland, and also placed $3 \mathrm{~m}$ away from the fenceline and oriented to magnetic north. The first $10 \mathrm{~cm}$ levels of TUs 1 and 2 were excavated before the end of the day.
The next day (July 25, 2006), the three test excavation units (TUs 1-3) were excavated to $99.3 \mathrm{~m}, 99.3 \mathrm{~m}$, and $99.2 \mathrm{~m}$, respectively, and TU 2 was found to contain the largest quantity of artifacts in the top three levels. The soil stain present at the surface of TU 1 was found to disappear below 3-5 cmbs, and the artifact recovery for both TUs 1 and 3 was very low. Although a few pieces of burned limestone were recovered, no evidence of an organized structure that could indicate a feature was observed. Throughout the levels the soils remained a loose silty loam, with moderately high concentrations of limestone pebbles throughout. Several root burrows and soil bioturbation was visible throughout the levels.

Photographs of the site and surrounding area were taken the second day, as well as GPS points of the existing box culverts and the low water crossing, the cedar oil processing mill, the fenceline, and the drainage location. At the end of the day it was decided to open up two more test excavation units (TUs 4 and 5) within the soil stain area near TU 2 to examine the stain further.

Excavations in TU 2 continued to recover artifacts in each level, but on July 26, 2006 a thick gravel lens was encountered at the bottom of level 6 (60-70 $\mathrm{cm}$ below datum [cmbd]; 99.4-99.3 m). It was decided to excavate this unit through the gravel lens to determine if cultural material was present beneath it. The gravel lens became less dense at about $99.25 \mathrm{~m}$ and ended at $99.16 \mathrm{~m}$, but the soils underneath it still had very high gravel content. Small amounts of debitage were recovered under the gravel lens from level 8 (80-90 cmbd; 99.2-99.1 m), but none were recovered from level 9 (90-100 cmbd; 99.1-99.0 m). Only the northern half of the final level at TU 2 was excavated, due to the paucity of artifacts and the dense gravels still present. Two lithic flakes were recovered, but no other cultural material was present. 


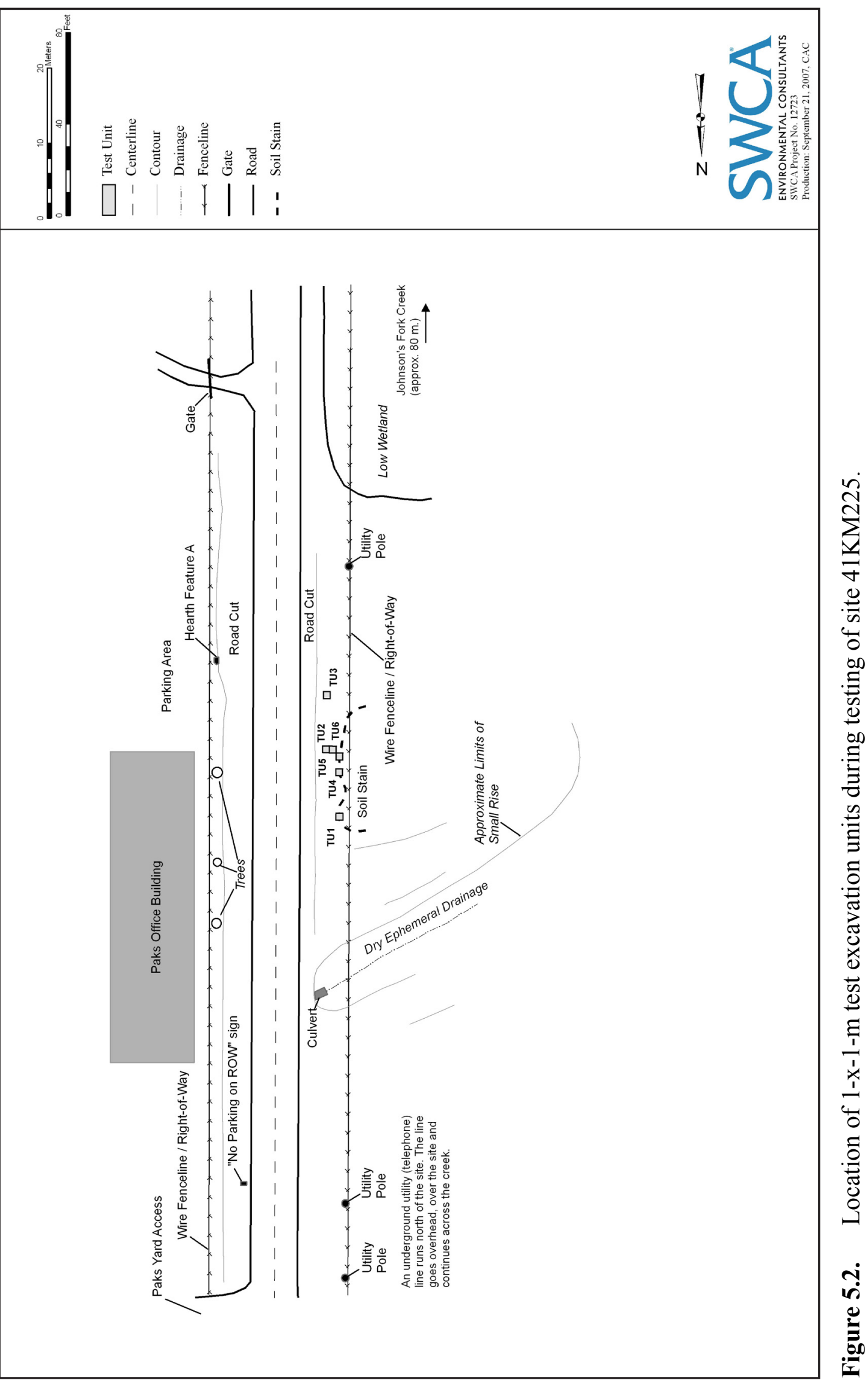






Figure 5.3. Ashy soil stain observed on site 41KM225 (facing north). The western ROW fence is on the left.

TUs 4 and 5 were opened up and excavated to depths of $99.6 \mathrm{~m}$ and $99.7 \mathrm{~m}$, respectively. Like TU 1, the ashy soil stain (which was brushed off the surface and screened separately) was only present in the top 3-5 cmbs (Figure 5.4). To see if the soil stain had any sign of a depression or dip, the first level of each unit was excavated in two halves to profile the stain within the unit. No depression was seen in the profile, and no associated burned rock was found within the soil stain. It appeared to be the result of a surface burn in recent decades (Figure 5.5). Artifact recovery from TUs 4 and 5 were highest at the top two levels (10-30 cmbd; 99.9-99.7 m), and decreased sharply at level $3(30-40 \mathrm{cmbd}$; 99.7-99.6 m). Bioturbation and root burrows were seen in both test excavation units, as well as significant amounts of limestone pebbles.
In addition to the investigations on the west side of the road, a portion of the road cut on the east side of the road was cleared of vegetation to examine the limestone burned rock midden. As the road cut showed signs of recent erosion and only the vegetation appeared to hold the soils in place, a minimal amount of clearing was instituted to reveal the exposed feature. The burned rock midden was designated Feature 1, and was observed to be located at or near the ground surface and extended $36 \mathrm{cmbs}$. Burned rock and artifacts were observed sliding down the road cut, and the southern and western ends of the feature had been truncated by the eroding road cut. Photographs were taken of the feature and surrounding area (Figure 5.6).

On July 27, 2006, TUs 4 and 5 were excavated to sterile soils at $50 \mathrm{cmbd}(99.5 \mathrm{~m})$ and terminated. To maximize the possibility of artifact recovery and exposure of potential features, TU 6 was opened between TU 2 and TU 4. This test excavation unit was excavated down three levels (8-40 cmbd; 99.92-99.60 m) and encountered similar soils, bioturbation, and gravel concentrations as the other test excavation units. Also like the other test excavation units, no features were located.

Meanwhile, three 20-x-40-cm shovel tests were excavated on top of the toe slope on the east side of the road, STs 3-5. ST 3 was placed in a location where Feature 1 was not visible in the road cut, and was excavated to $50 \mathrm{cmbs}$. A brown silty loam was encountered (10YR4/3), and one large burned limestone rock was uncovered at $5 \mathrm{cmbs}$ and five lithic flakes were collected from $20-40 \mathrm{cmbs}$. The soil became lighter and more compact between $40-50 \mathrm{cmbs}$, and no cultural material was observed. It was evident that ST 3 was not located in the feature. ST 4 was placed $10 \mathrm{~m}$ to the south, over what appeared to be the thickest part of Feature 1 in the road cut. As expected, a thick $35 \mathrm{~cm}$ layer of ashy soil, burned rock, and cultural material 


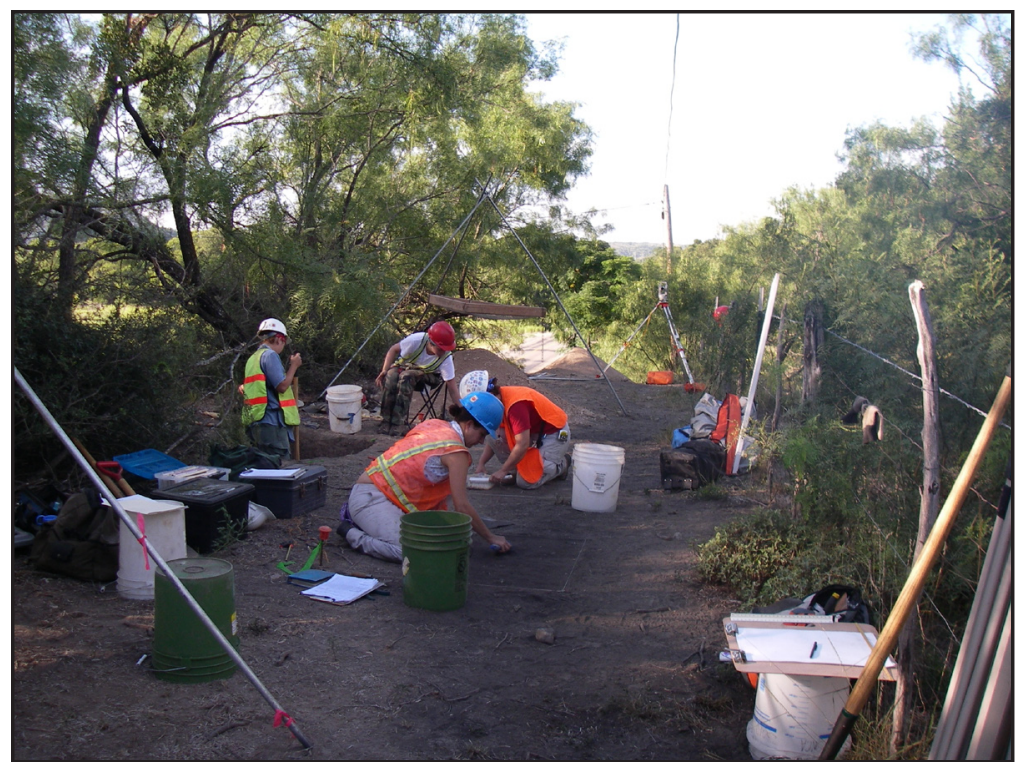

Figure 5.4. Removal of surface stain from TUs 4 and 5 (facing south).

was seen. The burned rock was generally small in size $(\sim 10 \mathrm{~cm})$. A quart-sized bag of soil was collected from the shovel test at $24-26 \mathrm{cmbs}$ for future analysis. The burned rock appeared to be sitting upon a layer of unburned limestone rocks and gravels, which were encountered between 35-45 cmbs. One final shovel test, ST 5, was excavated $10 \mathrm{~m}$ south of ST 4 , just before the small toe slope abruptly ends in the cutbank. Moderate quantities of burned limestone rocks were recovered and recorded between 10-50 cmbs, but no debitage and no ashy soils were encountered.

On July 28, 2006, the team returned to the site to backfill the test excavation units and make final measurements. A site map was completed, and all equipment was removed.

\section{SUMMARY OF LEVEL OF EFFORT}

During the testing investigations at site 41KM225, SWCA conducted hand excavations, special sampling, and other documentation at the project area. The minimum requirements in the scope of work were met with $3.38 \mathrm{~m}^{3}$ of hand excavations, the excavation of five shovel tests to determine site and feature limits, mapping of all excavations and topographical features, and the collection of all encountered artifacts and special samples. As shown in Table 5.1, the test excavation units focused on the deposits containing cultural material, and were generally terminated at or above the gravel lens. Only one test excavation unit (TU 2) was dug below the gravel lens to capture other possible Holocene deposits.

In addition to the hand excavations, the testing project excavated five shovel tests: two to determine the limits of cultural material at the site and three to determine the size and extent of Feature 1. STs 1 and 2 were placed just north of the hill on the west side of the road, defining the northern site limits, and STs 3-5



Figure 5.5. TU 1 showing the vertical extent of the surface stain on site $41 \mathrm{KM} 255$. 


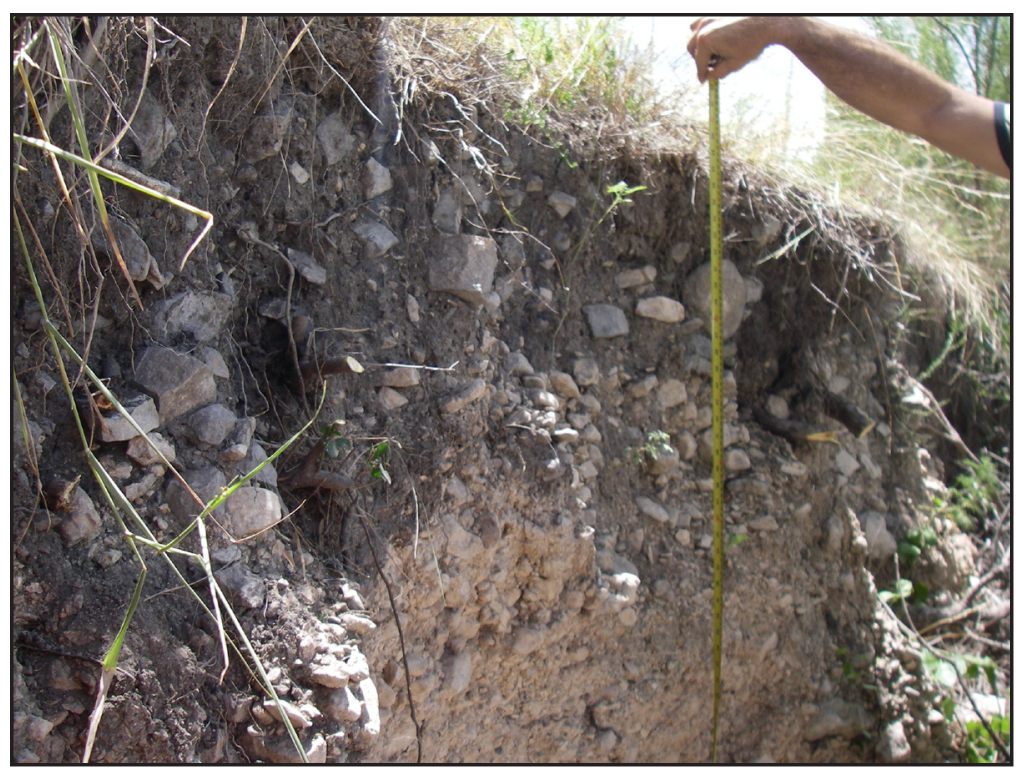

Figure 5.6. Profile of Feature 1, a burned rock midden, observed in the cutbank on the east side of FM 2169.

were excavated at 10-m intervals over Feature 1 to determine the extent of the ashy soils and the burned rock concentration. Other than these shovel tests, Feature 1 was not investigated further due to the narrowness of the remaining toe slope between the edge of the road cut and the edge of the ROW.

The entire site was mapped and photographed, and GPS data points were recorded to mark topographic elements and modern features. All subsurface artifacts were collected and documented, and surface utilized flakes, tools, and projectile points were collected. A charcoal sample was collected from TU 1 , and a soil matrix sample was collected from Feature 1 within ST 4.

\section{Results}

\section{SITE SIZE}

The exact dimensions of site $41 \mathrm{KM} 225$ are unknown at this time because it is believed that the site extends beyond the limits of the ROW on both the east and west sides. However, it seems that very little remains of the site on the east side of FM 2169 beyond the ROW. The cedar oil processing mill has impacted the ground surface from about $3 \mathrm{~m}$ to the east of the ROW fence line all the way to the end of the toe slope. The ground surface around the mill appears to have been graded and leveled; these activities have removed or altered whatever site deposits were present on the eastern edge of the toe slope.

Alternatively, the area beyond the western boundary likely contains additional intact cultural material. A review of aerial and topographic maps of the immediate area indicate that the western isolated portion of the toe slope extends approximately $40 \mathrm{~m}$ to the east before the small

Table 5.1. Excavated Volume of 1-x-1-m Excavation Units at 41KM225

\begin{tabular}{|c|c|c|c|c|}
\hline \multirow{2}{*}{ Test Unit } & \multicolumn{4}{|c|}{ Excavated Volume $\left(\mathbf{m}^{\mathbf{3}}\right)$} \\
\cline { 2 - 5 } & Cultural Deposit (AU 1) & Gravel Lens & Below Gravel Lens & Total \\
\hline 1 & 0.535 & 0.075 & 0.000 & 0.610 \\
\hline 2 & 0.700 & 0.140 & 0.210 & 1.050 \\
\hline 3 & 0.600 & 0.000 & 0.000 & 0.600 \\
\hline 4 & 0.400 & 0.000 & 0.000 & 0.400 \\
\hline 5 & 0.400 & 0.000 & 0.000 & 0.400 \\
\hline 6 & 0.320 & 0.000 & 0.000 & 0.320 \\
\hline Total & $\mathbf{2 . 9 5 5}$ & $\mathbf{0 . 2 1 5}$ & $\mathbf{0 . 2 1 0}$ & 3.380 \\
\hline
\end{tabular}


upland drainage turns south into Johnson Fork. A visual observation of this area indicates that it remains relatively undisturbed. Since surface and subsurface artifacts were located all the way to the ROW fence line on the west side FM 2169 , the site likely extends beyond the western ROW boundary to encompass the entire isolated toe slope.

However, for the purposes of this investigation the known extent of the site is at least $100 \mathrm{~m}$ east-west by $110 \mathrm{~m}$ north-south. The north-south dimension of the site is based on accumulated data derived from the SWCA investigations (test excavation units and shovel tests), and the east-west dimension is derived from the total width of the ROW. Obviously, the construction of the roadway has bisected the site within the known site limits, and the subsequent erosion of the cutbanks has also reduced the size of intact deposits. Thus, the intact portions of the site are only $5 \mathrm{~m}$ wide on the west side and $3 \mathrm{~m}$ wide on the east side.

The vertical limits of the site were determined from data derived from the test excavation units and visual observation of the cutbanks. The units were situated along the toe slope on the west side of the ROW, and cutbanks on both sides of the road were inspected. The majority of cultural material was recovered from the first 20-30 cmbs (100.0-99.7 m) on the west side of the road, and the burned rock feature seen in the eastern cutbank extended to a depth of $35 \mathrm{cmbs}$. The amount of cultural material decreased with depth until a mixed gravel lens was encountered at approximately 99.30-99.16 m. Within and below the gravel lens, a few isolated artifacts were recovered. The presence of these artifacts was primarily attributed to redeposition through post-depositional bioturbation at the site or other soil irregularities. Based on these observations, the cultural deposits that appeared to be the least disturbed range in thickness from $0-70 \mathrm{cmbs}$ (100.0-99.3 m).

\section{NATURAL StratigraPHY}

SWCA's archaeologists evaluated the stratigraphy of the site by means of individual test excavation units, shovel tests, and an examination of the road cut exposures throughout the site. The deeper deposits were primarily evaluated through TU 2 and the road cuts. A review of the local geology and soils as mapped by the Bureau of Economic Geology and the United States Department of Agriculture's Soil Conservation Service aided in the following descriptions.

\section{Stratigraphic Results}

The northern wall of TU 2 was cleaned and illustrated (Figure 5.7) and the strata described to the best extent possible. A geomorphologist was not utilized during this project, and thus all observations and interpretations are very general. The TU 2 profile showed deposits that were assigned to three groups: 1) an intact but compressed cultural deposit, 2) a gravel lens, and 3) an alluvial deposit with high gravel content and questionable artifact deposition.

The intact cultural deposit was generally defined by the presence of cultural material, and it is interpreted as a compressed surface through the recovery of two projectile points attributed to two different time periods. A Mid-Late Archaic Pedernales-like point and Middle Archaic Early Triangular-like point (see Chapter 6 for a more detailed discussion) were recovered within $10-15 \mathrm{~cm}$ of each other, indicating very little soil deposition between the different occupation periods. Artifacts seem to have moved vertically through the soil, but the highest concentrations are located within the top $30 \mathrm{cmbd}$. The uppermost soil was comprised of loose organic material and debris, with a color of very dark gray (10YR3/1). The soils beneath this top layer were described as silty clay loams with assorted fine- to medium-sized gravels, which increased in density (up to 40 percent) with depth. The soil 


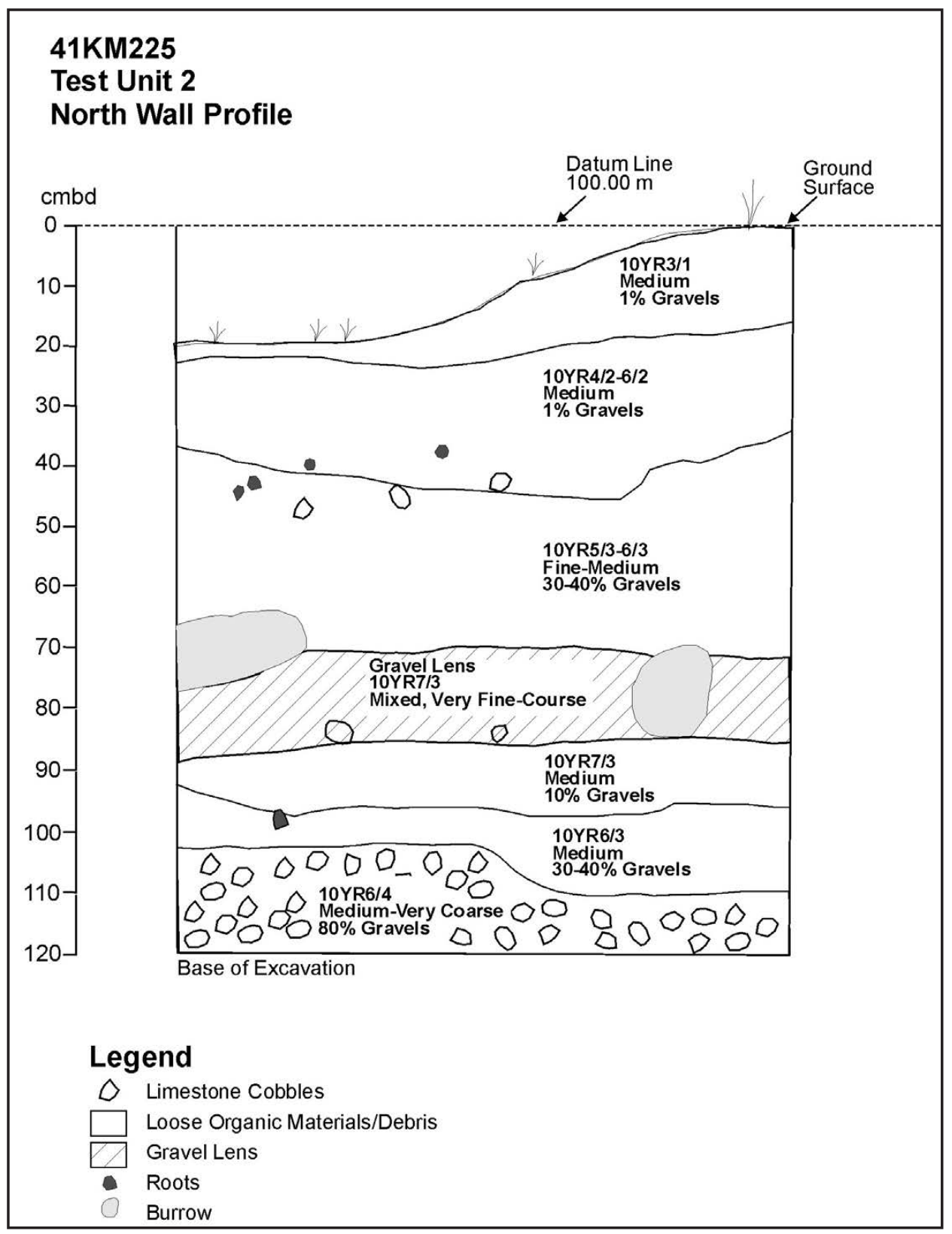

Figure 5.7. Profile of north wall of TU 2.

colors ranged from dark grayish-brown to pale brown (10YR4/2 to 10YR6/3). Roots and a few limestone cobbles were seen in the matrix, and the soils were loosely packed.

At about $70 \mathrm{cmbd}(99.3 \mathrm{~m})$ of the TU 2 profile, a gravel lens was encountered. The gravel lens consisted of mixed limestone and carbonate gravels and cobbles occupying 80-90 percent of the surrounding matrix. The amount of gravels and cobbles decreased slightly at approximately $75 \mathrm{cmbd}(99.25 \mathrm{~m})$, and terminated at $84 \mathrm{cmbd}$ (99.16 m). Large limestone cobbles were seen in the gravel lens, as well as two large burrows. The gravel lens was not at a consistent depth throughout the isolated hill on the west side of the row; TU 1, excavated to $99.3 \mathrm{~m}$, encountered the gravel lens at $99.375 \mathrm{~m}(62.5 \mathrm{cmbd})$, and TU 3 , excavated to $99.2 \mathrm{~m}$, did not encounter the gravel lens until the bottom of the unit $(80 \mathrm{cmbd}$, 
$99.2 \mathrm{~m}$ ). Although small in quantity, some lithic flaking material was located in the gravel lens.

The matrix below the gravel lens was significantly denser than the upper alluvial strata and was characterized by fine silty clay loam ranging in color from very pale brown to pale brown (10YR7/3 to 10 YR6/3). The gravel content decreased directly under the gravel lens, but increased again to 80 percent medium and coarse gravels towards the bottom of TU 2 (100 cmbd, $99.0 \mathrm{~m}$ ). As with the gravel lens, some lithic flakes were found in this deposit, but the small size of the artifacts and the heavy mixture of gravels in the matrix make in situ artifact deposition questionable. Only 10 flakes were found below the gravel layer, and these may be the result of post depositional alterations such as bioturbation. No definitive cultural layer was located beneath the gravel lens, and it is not interpreted as a cultural deposit.

An examination of the cutbanks on either side of FM 2169 showed several different layers of gravel lenses sandwiched between layers of silty clay loam, extending the full height of the cutbank (Figure 5.8). As with the test excavation units, all of the observed cultural material was located in the upper layers of the cutbanks, above the gravel lenses.

\section{INTERPRETATIONS}

The interpretations of the natural stratigraphy can only be very general in nature, and is based on the artifact recovery of the test excavation units and the known geomorphology of the toe slope on which the site sits. As expected, the deposits are generally level, but there is a slight slumping of the deposits at the southern end of the site and slight pinching towards the northern end of the site. This is shown by the gravel lens decreasing in elevation in the southernmost test excavation unit (TU 3) and increasing in elevation in the northernmost test excavation unit (TU 1). The bulk of the cultural material was located in the top 30-40 cmbd. Based on the relatively shallow extent of cultural deposits, the majority of the site has experienced very little soil deposition in the Holocene, and has also been exposed to heavy surficial erosion. This has caused a compression of artifacts with no discernable cultural context or separation of deposits. In addition, evidence of bioturbation has indicated that a few artifacts have sunk into non-cultural deposits, dispersing the evidence of an occupation surface(s) to different depths. Finally, large sections of the site have eroded away or have been impacted by the construction of the roadway and the cedar oil processing mill, altering the natural stratigraphy even more.

\section{Cultural Components}

Only one cultural component, Analytical Unit (AU) 1, was documented during the testing excavations. AU 1 is defined as a mixed assemblage and associated cultural components within one gradually aggrading upland depositional unit, spanning from the ground surface to the gravel lens at $99.3 \mathrm{~m}$. Although artifacts were found at lower elevations, the presence of these artifacts is generally attributed to post depositional movement of lithic flakes through the deposits, based on the current interpretation. Unfortunately, the compression of the stratigraphy and the bioturbation of the artifacts within the investigated areas have altered any discrete occupation surfaces. Thus, even though two projectile points were found within AU 1 that possibly date to different occupation periods (Middle Archaic and middle Late Archaic [see Chapter 6]), the difficulty in distinguishing any distinct occupation surfaces make dividing the cultural deposit into more discrete analytical units unfeasible at this stage of analysis. Table 5.2 shows a matrix of the quantities of recovered cultural material within their respective depths. The test excavation units are arranged from south to north, and the levels 
5-10 Chapter 5

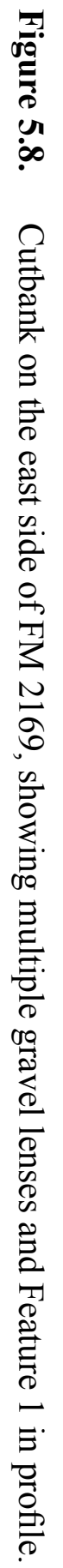



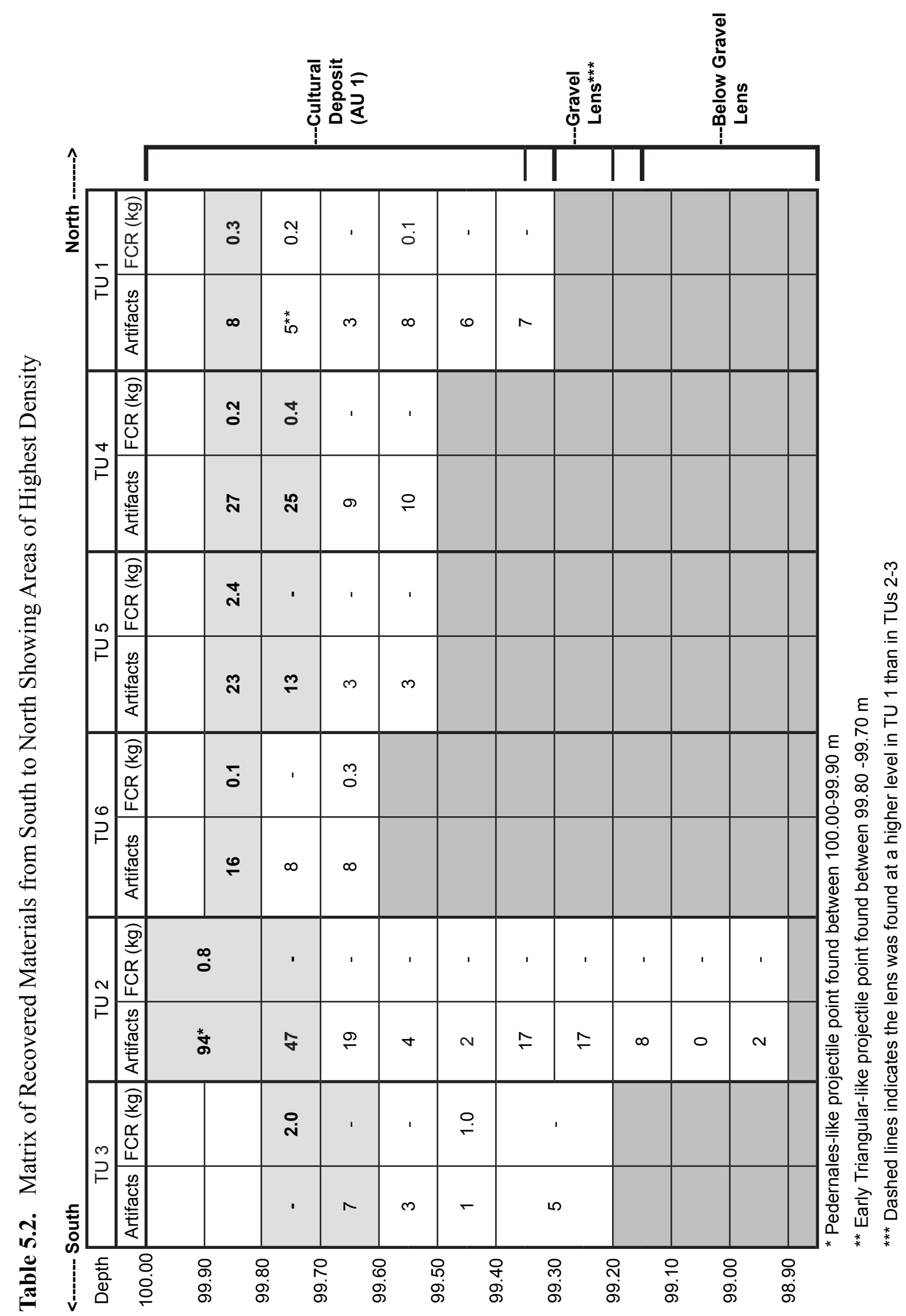




\section{5-12 Chapter 5}

of highest artifact recovery are highlighted with a pattern. As shown in the table, the highest artifact recovery was towards the surface, and there is no clear distinction between different occupation surfaces in the artifact recovery. Thus, the deposits defining AU 1 cannot at this time be further refined into more discrete temporal zones.

However, in a broader interpretation, AU 1 can be correlated to the natural stratigraphy at the site, which includes the gravel lens and the deposits under it. The gravel lens was found at a general elevation of $70 \mathrm{cmbs}(99.3 \mathrm{~m})$, and was apparent in the test units and road cut profiles throughout the investigated portion of the site. As this gravel lens marked a different depositional event than the silty clay loam deposits above it, the lens was the most appropriate termination point for AU 1. As such, the following descriptions generally will give an above and below the gravel lens references to artifacts where appropriate. The summary of AU 1 includes descriptions of its temporal association, stratigraphy, horizontal extent, and associated features and artifacts.

\section{Analytical Unit 1}

Evidence of AU 1 was found in all of the test excavation units, shovel tests, and the eastern cutbank, where Feature 1 is located. As mentioned above, two semi-identifiable projectile points were located in AU 1. One unidentifiable point was also located on the surface. Other than the slight slumping at the southern end of the site and the slight pinching at the northern end of the site, AU 1 appears to occupy a roughly level area on the isolated "hill" of the toe slope.

\section{TIME PERIOD}

AU 1 dates to the Middle Archaic (5,7005,500 в. Р.) and the middle Late Archaic
(3,300-2,300 B.P.), based on the presence of two projectile points, an Early Triangular-like point and a Pedernales-like point (Collins 2004; Turner and Hester 1993). An untypeable point that bears some similarity to a Trans-Pecos Paisano point was also recovered from the surface. If this point were manufactured at the same time as the Paisano, it would date to Turner and Hester's (1993) Transitional Archaic (200 B.C. to A.D. 600 , or around 2,150-1,350 B.P.).

Alternatively, the single charcoal sample submitted for radiocarbon assay returned a $2 \delta$ 1160-1270 cal A.D. date, which would place the deposits in the Late Prehistoric. This contradicts the chronology established by the projectile point typology, as this sample was found at least $20 \mathrm{~cm}$ below the Early Triangular-like point and at least $40 \mathrm{~cm}$ below the Pedernaleslike point. Several explanations may account for the discrepancy, but the soil compression and extensive bioturbation observed in the AU 1 deposits are the most likely contributors. The presence of the charcoal at a lower level than it ought to be is further evidence that the distribution of cultural material in AU 1 is a result of mixed assemblages from several occupation surfaces.

\section{Stratigraphic Position and Vertical Limits}

The vertical extent of AU 1 is best observable in TU 2 and the cutbanks along FM 2169. Although the majority of the artifacts were recovered in the top 30-40 cmbs, artifacts continued through the remainder of the cultural deposit above the gravel lens. This deposit is relatively level, with slight variations in elevation at the southern and northern ends of the site. Thus, the vertical limits are defined as the ground surface $(100.00 \mathrm{~m})$ to $99.3 \mathrm{~m}(0-70 \mathrm{cmbd})$. 


\section{Horizontal EXTENT}

The horizontal extent of AU 1 is not entirely known, but the component appears to largely span the entire site. Shovel tests were used to define the site limits, and the positive shovel tests all found cultural material at the same elevation as AU 1 (i.e., near the surface). AU 1 likely extends both west and east of the APE onto private property. However, AU 1 has been severely impacted by the roadway's path through the deposit, as well as the construction of the cedar oil processing mill to the east on private property.

\section{FEATURE}

AU 1 contains one primary feature. Feature 1 was only visible in the eastern FM 2169 road cut and was investigated with shovel tests and sampling to determine relative depth of deposits and content. There was no evidence of Feature 1 along the west side of the roadway or in any of the test excavation units.

\section{Feature 1 (9-45 cmbs, approximately 99.80-99.44 m)}

Feature 1 is a small discrete cluster of burned limestone that was observed in the eastern cutbank of FM 2169 (Table 5.3). The feature does not appear to be basin-shaped, but instead appears to be an asymmetrical stack of rocks in the profile (Figures 5.6 and 5.8). The limestone rocks were observed to be generally around 8-15 $\mathrm{cm}$ in diameter and angular in shape. The stack is six-stones thick in some places, and is disbursed across an area $15 \mathrm{~m}$ north-south by at least 3.2 $\mathrm{m}$ east-west. It appears that a large chunk of the feature has been impacted by the construction of FM 2169, as well as subsequent erosion of the cutbank. Several pieces of burned rock were seen in the loose soil piles at the bottom of the cutbank.

The feature was investigated with three shovel tests on the small area of undisturbed toe slope on the east side of the road between the edge of the cutbank and the private property fence line (STs 3-5). ST 3 did not encounter the feature itself,

Table 5.3. Details of Feature 1 from 41 KM 225

\begin{tabular}{|l|l|}
\hline Feature & 1 \\
\hline Context & Cultural Deposit (AU 1) \\
\hline Provenience & $\begin{array}{l}\text { On southern edge of toe slope on east side } \\
\text { of roadway }\end{array}$ \\
\hline Depth Below Surface & $9-45 \mathrm{cmbs}$ \\
\hline Size & $15 \mathrm{~m} \mathrm{~N}-\mathrm{S} \times 3.2 \mathrm{~m} \mathrm{E-W}$ \\
\hline Associated Materials & $\begin{array}{l}\text { Debitage, Scraper, Fire Cracked Limestone } \\
\text { Rock }\end{array}$ \\
\hline Burned Rock Count & 99,000 (estimate) \\
\hline Estimated Total Mass & $8,030 \mathrm{~kg}$ (estimate) \\
\hline Rock Type & Limestone, Chert \\
\hline Degree of Fracturing & unknown \\
\hline Clast Arrangement & unknown \\
\hline Planiform Shape & unknown \\
\hline Profile Shape & unknown \\
\hline
\end{tabular}




\section{5-14 Chapter 5}

but did recover four lithic flakes, one scraper, and one piece of burned limestone about $10 \mathrm{~cm}$ in diameter at $5 \mathrm{cmbs}$. ST 4 encountered the feature at $9 \mathrm{cmbs}$, containing dense burned rocks and ashy soils. Table 5.4 shows the density of the burned rock and other recovered artifacts throughout the shovel test. It was noted that the upper layers of rocks were closer to $10 \mathrm{~cm}$ in diameter, while the lower layers were smaller, more like 5-6 cm in diameter. A soil matrix sample was collected from Feature 1, ST 4 at $24-26 \mathrm{cmbs}$. The burned limestone rocks terminated at $45 \mathrm{cmbs}$, and unburned limestone cobbles appeared in ST 4 below the feature. These cobbles were not surrounded by ashy soil. ST 5 also encountered Feature 1, but no ashy soils were observed with the burned limestone rock. In addition, no lithic material was seen in
ST 5. See Table 5.4 for the density of burned rock in ST 5.

As Feature 1 was not investigated further, the exact shape and size of the feature is unknown. Feature 1 does not show the typical basin shape of an intact hearth in the observed portion in the eastern cutbank, but does contain a dark organic matrix. The exact function of the feature is unknown due to the large amount of disturbance caused by the road construction. However, according to Leroy Johnson (2000:73), “... it is sensible to believe that one is dealing with an oven when the feature has rocks piled one upon another." Therefore, based on Johnson's (2000) interpretation and the $15 \mathrm{~m}$ north-south extent of burned rock observed in profile, Feature 1 is likely an oven utilized for covered roasting

Table 5.4. Burned Rock Densities and Materials Recovered From Feature 1 Shovel Tests

\begin{tabular}{|c|c|c|c|c|c|c|}
\hline \multirow[b]{2}{*}{ Shovel Test } & \multirow{2}{*}{$\begin{array}{l}\text { Depth } \\
\text { (cmbs) }\end{array}$} & \multirow[b]{2}{*}{ Soil Color } & \multirow[b]{2}{*}{ Soil Texture } & \multicolumn{2}{|c|}{ Burned Rock } & \multirow[b]{2}{*}{ Debitage } \\
\hline & & & & Size $(\mathrm{cm})$ & Count & \\
\hline \multirow{2}{*}{3} & $0-40$ & Brown (10YR4/3) & Silty Loam & $5-10$ & 1 & 4 (1 scraper) \\
\hline & $40-50$ & Brown (10YR5/3) & Silty Loam & - & - & - \\
\hline \multirow{11}{*}{4} & $0-9$ & Black (10YR2/1) & Silty Loam & - & - & - \\
\hline & $9-20$ & Black (10YR2/1) & Silty Loam & $0-5$ & $75+$ & 1 \\
\hline & & & & $5-10$ & 24 & \\
\hline & & & & $10-15$ & 2 & \\
\hline & $20-40$ & Black (10YR2/1) & Silty Loam & $0-5$ & $75+$ & 7 \\
\hline & & & & $5-10$ & 48 & \\
\hline & & & & $10-15$ & 2 & \\
\hline & $40-45$ & Black (10YR2/1) & Silty Loam & $0-5$ & $20+$ & 2 \\
\hline & & & & $5-10$ & 10 & \\
\hline & & & & $10-15$ & 1 & \\
\hline & $45+$ & Brown (10YR6/2) & Silty Loam & - & - & - \\
\hline \multirow{6}{*}{$\mathbf{5}$} & $0-10$ & Cedar Mulch & & & & \\
\hline & $10-30$ & Dark Brown (10YR4/2) & Silty Loam & $0-5$ & $10+$ & - \\
\hline & & & & $5-10$ & 3 & \\
\hline & & & & $10-15$ & 2 & \\
\hline & $30-50$ & Dark Brown (10YR4/2) & Silty Loam & $0-5$ & $10+$ & - \\
\hline & & & & $5-10$ & 10 & \\
\hline
\end{tabular}


Table 5.5. Total of All Materials Recovered From 41KM225 Testing

\begin{tabular}{|c|c|c|}
\hline Artifact Type & Count & Density* $^{*}$ \\
\hline Charcoal & 1 & 0.30 \\
\hline Soil Samples & 1 & 0.30 \\
\hline Biface & 6 & 1.78 \\
\hline Core & 3 & 0.89 \\
\hline Projectile Point & 3 & 0.89 \\
\hline Debitage & 363 & 107.40 \\
\hline Scraper & 5 & 1.48 \\
\hline Informal Tool & 4 & 1.18 \\
\hline Groundstone & 1 & 0.30 \\
\hline Shell & 1 & 0.30 \\
\hline FCR Count & 336 & 99.41 \\
\hline FCR Weight $(\mathrm{kg})$ & 7.9 & 2.34 \\
\hline
\end{tabular}

*Density is the approximate number of items per cubic meter of excavation

Table 5.6. Materials Recovered From Test Excavation Units by Context

\begin{tabular}{|c|c|c|c|c|c|c|}
\hline \multirow{2}{*}{ Artifact Type } & \multicolumn{2}{|c|}{ Cultural Deposit (AU 1) } & \multicolumn{2}{c|}{ Gravel Lens } & \multicolumn{2}{c|}{ Below Gravel Lens } \\
\cline { 2 - 7 } & Count & Density* & Count & Density* & Count & Density $^{*}$ \\
\hline Charcoal & 1 & 0.34 & 0 & 0.00 & 0 & 0.00 \\
\hline Biface & 4 & 1.35 & 0 & 0.00 & 0 & 0.00 \\
\hline Core & 3 & 1.02 & 0 & 0.00 & 0 & 0.00 \\
\hline Projectile Point & 2 & 0.68 & 0 & 0.00 & 0 & 0.00 \\
\hline Debitage & 321 & 108.63 & 23 & 106.98 & 2 & 9.52 \\
\hline Scraper & 3 & 1.02 & 0 & 0.00 & 0 & 0.00 \\
\hline Informal Tool & 3 & 1.02 & 0 & 0.00 & 0 & 0.00 \\
\hline Groundstone & 1 & 0.34 & 0 & 0.00 & 0 & 0.00 \\
\hline Shell & 0 & 0.00 & 1 & 4.65 & 0 & 0.00 \\
\hline FCR Count & 46 & 15.57 & 0 & 0.00 & 0 & 0.00 \\
\hline FCR Weight (kg) & 7.9 & 2.67 & 0 & 0.00 & 0 & 0.00 \\
\hline
\end{tabular}

*Density is the approximate number of items per cubic meter of excavation 
Table 5.7. AU 1 Recovery Summary

\begin{tabular}{|c|c|c|c|c|c|c|c|c|c|c|c|}
\hline 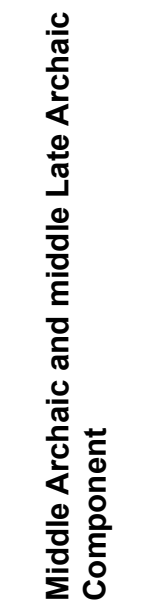 & 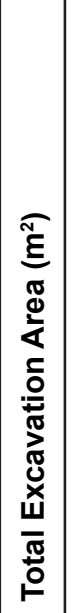 & 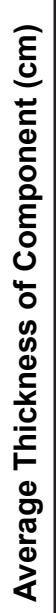 & 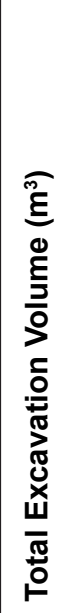 & 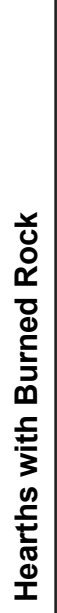 & 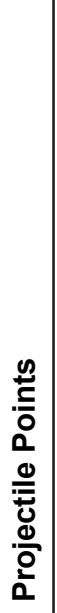 & 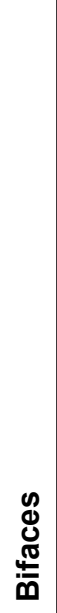 & $\begin{array}{l}\mathscr{y} \\
\grave{d} \\
\mathcal{O}\end{array}$ & $\begin{array}{l}\text { め) } \\
\frac{0}{0} \\
\frac{0}{\pi} \\
\text { 心 }\end{array}$ & 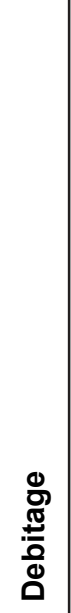 & 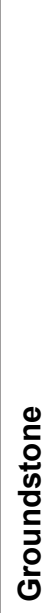 & 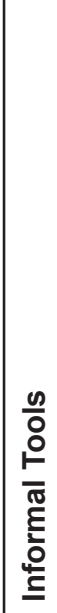 \\
\hline 41KM225 & 6 & 20 & 2.9 & 1 & 2 & 4 & 3 & 3 & 321 & 1 & 3 \\
\hline
\end{tabular}

or baking and due to repeated use has created a small burned rock midden. However, this interpretation is limited due to the portion of the feature that remains undisturbed is very small, with approximately half of the feature remaining in a 15-x-3.5-m area.

\section{MATERIAL RECOVERED}

The material recovered in the intact prehistoric culture component consist of six bifaces, 363 pieces of debitage, five scrapers, four informal tools, three cores, one piece of groundstone, and three projectile points (Table 5.5; Appendix A). Most of the artifacts were found in AU 1, but, as mentioned above, a few artifacts were recovered from the gravel lens and the soils beneath the lens. Table 5.6 shows the artifacts recovered from the test excavation units separated by deposit. The three projectile points are not entirely diagnostic but have attributes similar to a Pedernales point, an Early Triangular point, and a Paisano point. The primary intact deposit and highest artifact density occur in the first two levels of excavation throughout the site, from 99.8-99.6 in TU 3, $100.0-99.8$ in TU 2, and $99.9-99.7 \mathrm{~m}$ in TUs $1,4,5$, and 6 (Table 5.2). Table 5.7 displays the total recovered material and volumes excavated from AU 1, which dates to the Middle Archaic (5,700-5,500 в.Р.) and the middle Late Archaic (3,300-2,300 в.P.) based on diagnostic artifacts. Detailed descriptions of materials recovered are presented in Chapter 6. 


\section{Chapter 6}

\section{Recovered Materials}

\section{Michael Chavez}

\section{ReCOVEREd MATERIAL}

The materials recovered from site 41KM225 consist of six bifaces, 363 pieces of debitage, five scrapers, four informal tools, three cores, one piece of groundstone, and three projectile points (Table 6.1; Appendices A and C). The vast majority of artifacts were found in AU 1, with a few artifacts recovered from the gravel lens and the soils beneath the lens. Table 6.2 shows the artifacts recovered from the test excavation units separated by elevation and matrix deposits. The primary intact deposit and highest artifact density occurred in the upper two levels of excavation throughout the site, from 99.8-99.6 $\mathrm{m}$ in TU 3, $100.00-99.8 \mathrm{~m}$ in TU 2, and $99.9-99.7 \mathrm{~m}$ in TUs $1,4,5$, and 6 (Table 6.2).

\section{Projectile Points}

Three projectile points were recovered from the test units and surface of site 41KM225. Although none of the points could be decisively typed, they share characteristics with a Pedernales point, an Early Triangular point, and a Paisano point, respectively. It should be noted that although these points have characteristics of the points listed above, they have enough alternate characteristics to obscure certain classifications.

The Pedernales-like point was recovered from TU 2, top of level 1, between 100.0 and $99.8 \mathrm{~m}$. Original dimensions could not be determined since only the basal and a single stem portion of the point was recovered. However, the recordable dimensions consist of a max stem length of 16.95 $\mathrm{mm}$, a neck width of $22.44 \mathrm{~mm}$, and a stem base width of $21.62 \mathrm{~mm}$. The point did not display any evidence of heat treatment or patination.

Pedernales points are common to central Texas with a moderate amount (11-51) found in Kimble County and the same number found in the surrounding counties of Gillespie and Kerr (Prewitt 1995). These points are usually grouped into the "Middle Archaic" in conventional Canyonlands chronology. Collins (2004:113), however, aligns this era as the "middle" part of his Late Archaic period, roughly 3,300-2,300 B.P., while Turner and Hester (1993:171), using the Middle Archaic label, place them at 2000-1200 B.C. (roughly $3,950-3,150$ в.P.). Although the specimen recovered in TU 2 displays rectangular, bifurcated stem, it does not display a broad, flute-like flake on the basal concavity (Figure 6.1) (Turner and Hester 1993).

Table 6.1. Total of All Materials Collected From 41KM225 Testing

\begin{tabular}{|c|c|}
\hline Artifact Type & Count \\
\hline Charcoal & 1 \\
\hline Core & 3 \\
\hline Debitage & 363 \\
\hline Biface & 6 \\
\hline Scraper & 5 \\
\hline Groundstone & 1 \\
\hline Informal Tool & 4 \\
\hline Projectile Point & 3 \\
\hline Soil Sample & 1 \\
\hline Fire Cracked Rock & 390 \\
\hline
\end{tabular}




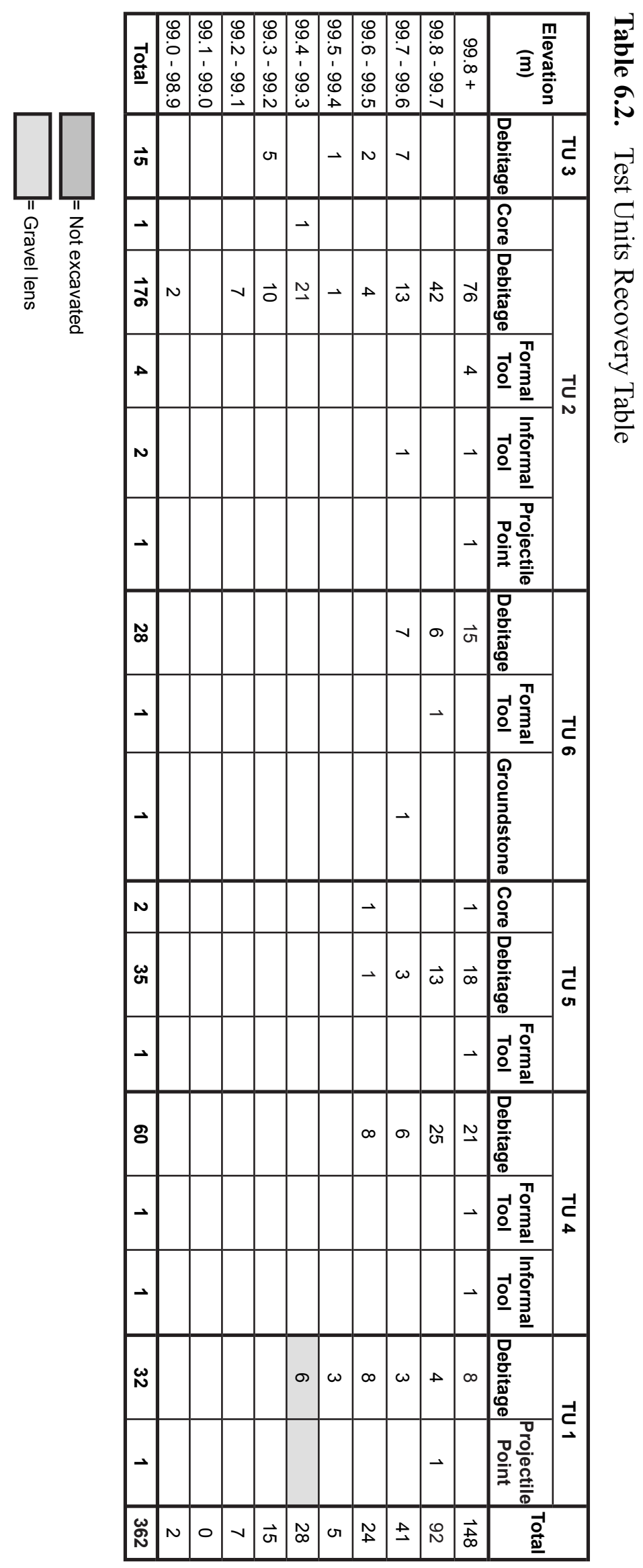




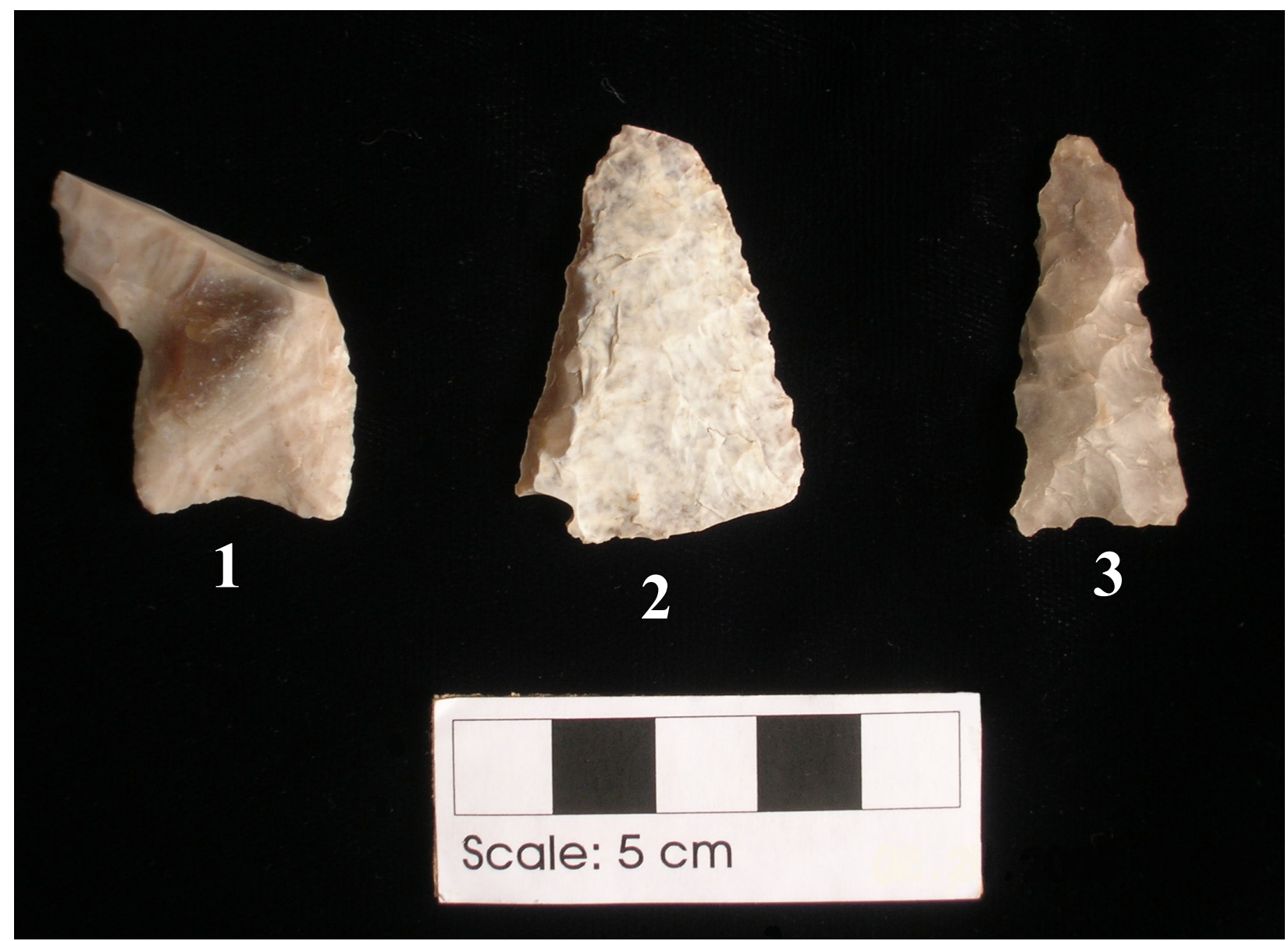

Figure 6.1. Projectile points found at 41KM225: 1) Pedernales-like point (top of level 1 in TU 2, 100.0-99.9 m), 2) Early Triangular-like point (level 2, TU 1, 99.8-99.7 m), and 3) Paisano-like point (surface).

The Early Triangular-like point was recovered from TU 1, in level 2, between $99.8 \mathrm{~m}$ and $99.7 \mathrm{~m}$. The point measures $45.28-\mathrm{x}-28.89 \mathrm{~mm}$ with a maximum thickness of $5.49 \mathrm{~mm}$. These points have been dated to the Early Archaic by Turner and Hester (1993:108) at 3700-3600 B.C. (roughly 5,650-5,550 в.P.). However, if the established dates for Early Triangular points are placed within the chronology developed by Collins (2004:113), the period would be the Middle Archaic. This period designation is supported by other researchers for central Texas Early Triangular points (Black and Quigg 2007; Mahoney et al. 2002). The point did not exhibit any evidence of heat treatment and displayed a heavy patina on both surfaces. This specimen displays the careful parallel oblique flaking and straight to slight concave bases but does not display the alternately beveled lateral edges as indicative of this type (Turner and Hester 1993). Nevertheless, the general shape and the fine marginal pressure flaking lend to the similarities of this specimen with the Early Triangular point type (Figure 6.1). However, the possibility that this point is more like a Tortugas cannot be discounted. This would place the point in the Late Middle Archaic, at 850-600 B.C. (roughly 2,800-2,550 B.P.; Turner and Hester 1993).

The final projectile point, a Paisano-like point, was found on the surface of the site on the western portion of the ROW near TU 1. However, the specimen has no signs of side notching. This point is considered undiagnostic, however the 
similarities displayed with those of a Paisano point must be noted (Figure 6.1). Paisano points are usually found in the Trans-Pecos region of Texas and are dated to the Transitional Archaic, around 200 B.C. to A.D. $600(2,150-1,350$ B.P.; Turner and Hester 1993). A study performed by Elton Prewitt (1995) determined that the closest recorded Paisano point to Kimble County was in Val Verde County, approximately 60 miles to the west at its closest point. Paisano points have straight to convex lateral edges that are sometimes serrated with a stem formed from shallow side notches and a concave to deeply indented base. The overall dimensions of the point are $39.92-x-18.89 \mathrm{~mm}$ with a maximum thickness of $6.00 \mathrm{~mm}$. The specimen recovered on 41KM225 has straight serrated edges with what appears to be an attempt at a concave base.

\section{BIFACES}

Six bifacial tools were recovered during testing at site $41 \mathrm{KM} 225$. Two were recovered from the surface near the test units, while the rest were recovered from TUs 2, 5, and 6 . The bifaces consisted of two complete bifaces, one medial fragment, and three indeterminate fragments. The complete bifaces are early stage, amorphous specimens found on the surface and level 1 of TU 2. The complete surficial bifacial tool could be described as a hand axe or battering tool with heavy battering on the two utilized edges (Figure 6.2). The additional complete biface is a small (65.10-x-50.00 mm, with a thickness of $21.30 \mathrm{~mm}$ ) crude early stage biface with minimal evidence of utilization.

Three of the bifacial fragments were found in test units and one was found on the surface. All the test unit fragments were recovered within the first two levels at elevations no lower than $99.7 \mathrm{~m}$ and are smaller fragments of middle to late stage bifaces (Table 6.3). The surficial fragment is a larger (width=75.2 $\mathrm{mm}$ ) amorphous specimen with cortex present on both surfaces (Figure 6.3). Although both surfaces are worked (hence the biface designation), the final stages of reduction appear to be bidirectional with no apparent continuous bifacially worked lateral edge.

\section{SCRAPERS}

A total of five scrapers was recovered from site 41KM225. These consist of one complete end scraper, one end and side scraper fragment, one

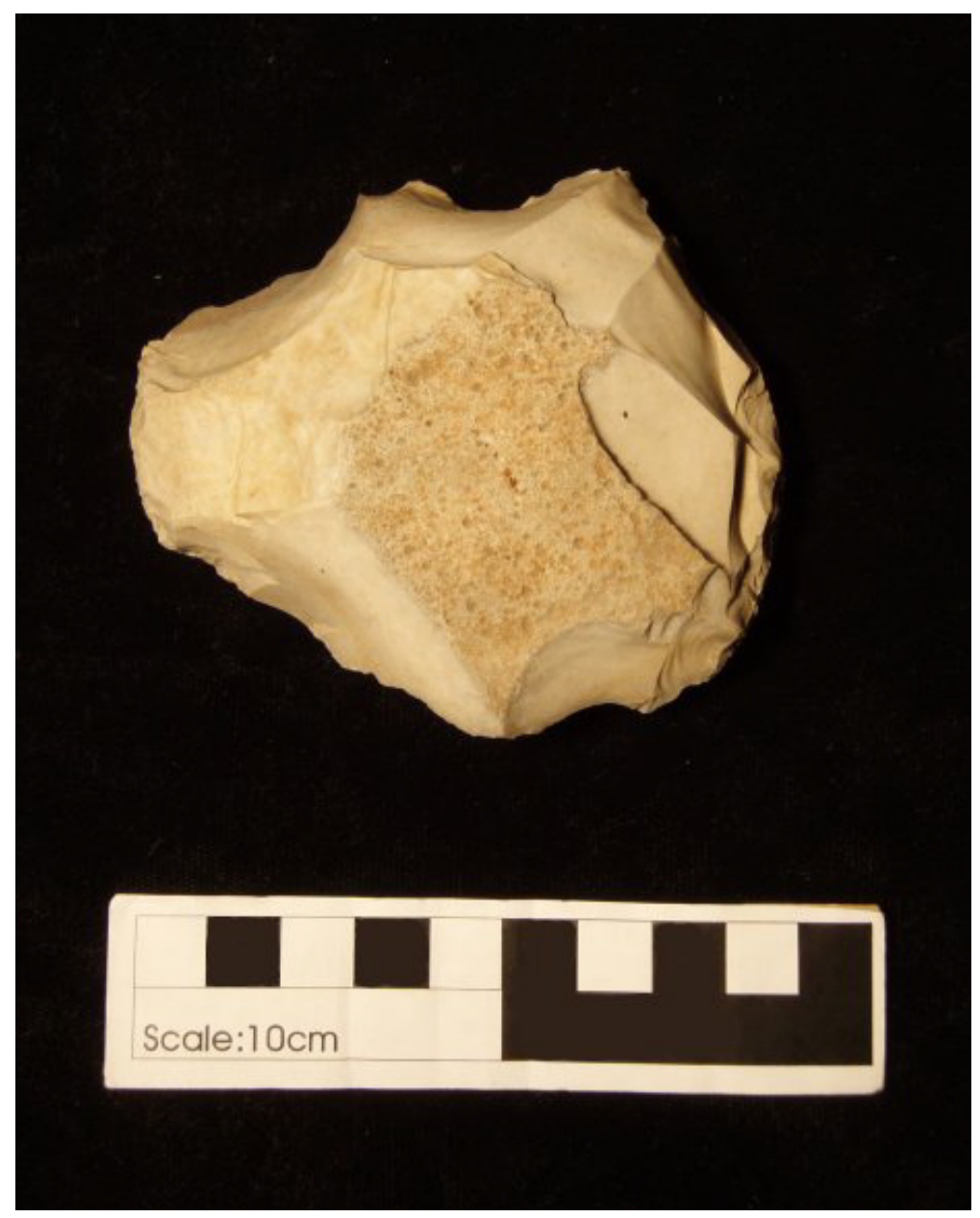

Figure 6.2. Surficial bifacial tool described as a hand axe or battering tool. 
Table 6.3. Biface Recovery by General Elevation

\begin{tabular}{|c|c|c|c|}
\hline Depth & Complete & Fragment & Total \\
\hline Surface & 1 & 1 & 2 \\
\hline $99.8+$ & 1 & 2 & 3 \\
\hline $99.8-99.7$ & - & 1 & 1 \\
\hline Total & $\mathbf{2}$ & $\mathbf{4}$ & $\mathbf{6}$ \\
\hline
\end{tabular}

end scraper fragment, and two indeterminate scraper fragments (Figure 6.4). The complete end scraper was recovered from level 1 of TU 2 between $100 \mathrm{~m}$ and $99.8 \mathrm{~m}$ and has dimensions of $45.1-\mathrm{x}-51.8 \mathrm{~mm}$ with a maximum thickness of $9.9 \mathrm{~mm}$. The unifacially worked distal margin of the scraper accounts for approximately 20 percent of the entire perimeter length of the specimen.

The end and side scraper fragment was also recovered from level 1 of TU 2 . The bifacially worked portions of the fragment are along the distal, proximal, and right lateral margin with the left lateral margin and a portion of the distal margin missing. The end scraper distal fragment was recovered from level 1 of TU 4 between 99.9 and $99.8 \mathrm{~m}$. The unifacially worked edge is along the distal margin of the heavily patinated fragment.

The indeterminate scraper fragments consist of a bifacially worked marginal fragment and a unifacially worked indeterminate fragment. The marginal fragment has multiple breaks with cortex present along the dorsal surface. The indeterminate fragment has a transverse break with the worked edge towards the dorsal surface along the left lateral margin.

\section{INFORMAL TOOLS}

Three retouched flakes and one utilized flake fragment constitute the informal tools recovered from site 41KM225. Retouched flakes were defined as non-patterned expedient tools deliberately retouched to form a working edge on a flake (Hill 2006). Utilized flakes differ morphologically from retouched flakes in that they exhibit use wear as indicated by dulled, shattered, or micro-flaked edges rather than deliberate retouch along one or more flakes edges (Hill 2006).

The retouched flakes consist of two complete flakes and one indeterminate flake fragment. Both complete flakes show working along the distal, right lateral, and left lateral margins with one being bifacially worked and the other worked unifacially towards the ventral surface.

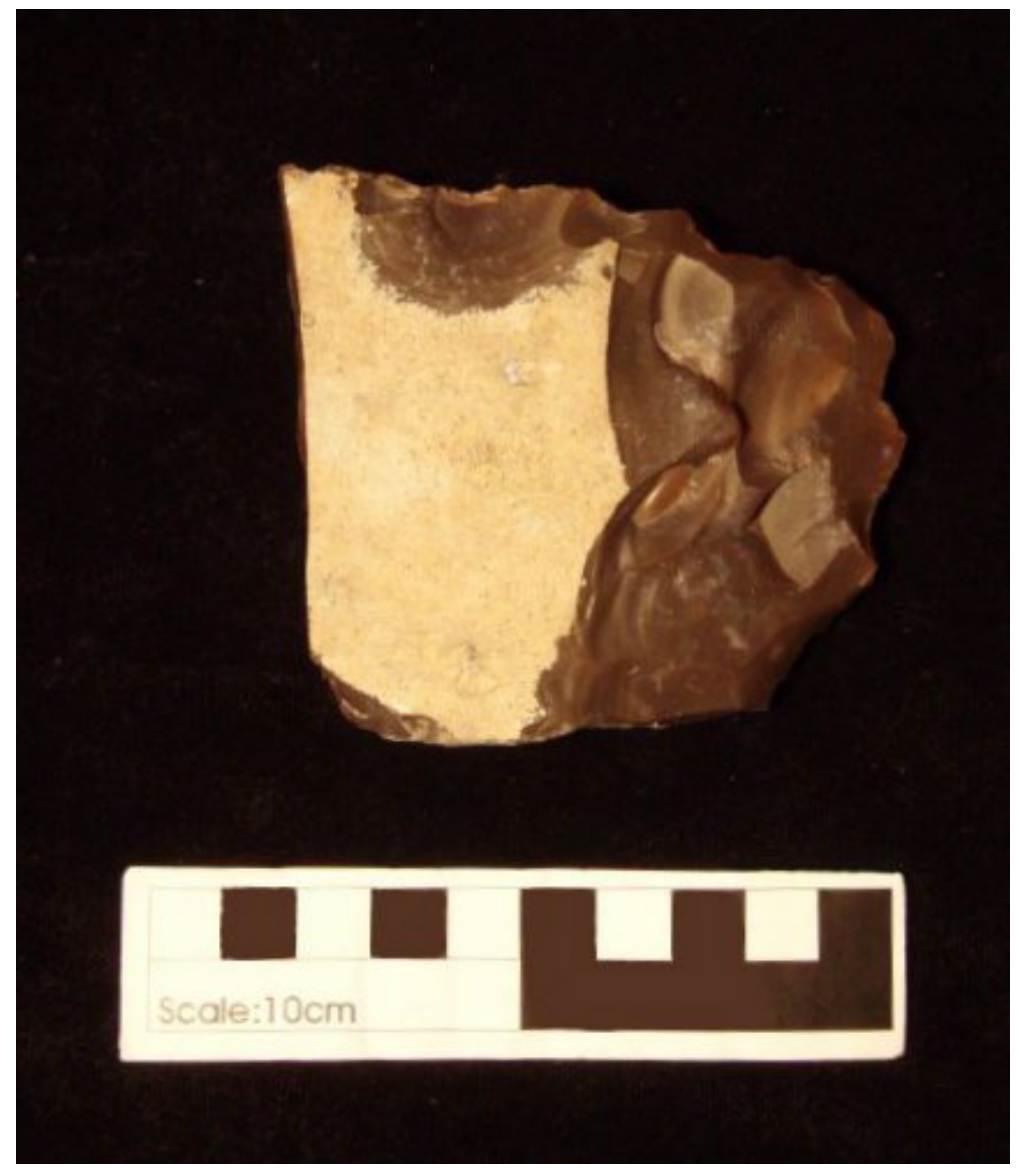

Figure 6.3. Surficial bidirectional bifacial fragment. 
The bifacial retouched flake was recovered on the surface near TU 3 while the unifacially worked flake was found in level 1 of TU 4. The retouched flake fragment, recovered in level 1 of TU 2, is worked bidirectionally along an unknown margin. All of the specimens have a heavy patina with no evidence of heat treatment.

The utilized flake fragment was recovered in level 3 of TU 2, between 99.7 and $99.6 \mathrm{~m}$ in $\sim 20-30 \mathrm{cmbs})$. The fragment shows bidirec- tional utilization along an indeterminate margin with no patina or evidence of heat treatment across the entire specimen.

\section{CORES}

The three cores recovered at site 41KM225 consist of two complete specimens and one core fragment. One of the complete cores is likely a tested cobble due to the minimal number of negative flake scars present on the specimen. This tested core was recovered in level 1 of TU

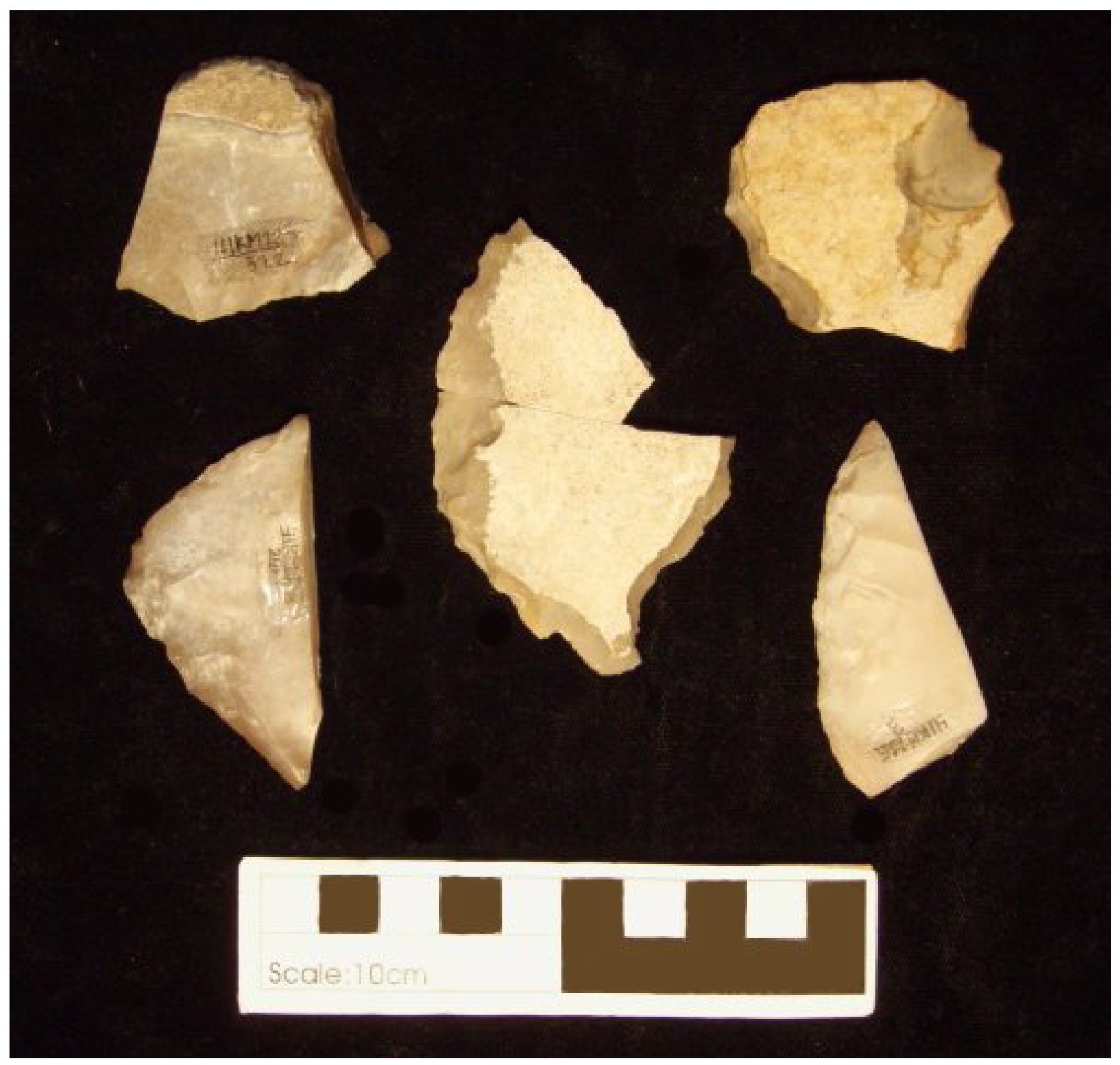

Figure 6.4. Scrapers recovered from site 41KM225. 
5 between 99.9 and $99.8 \mathrm{~m}$ in elevation. The core is rather large (76.4-x-50.7-x-39 mm) and is made from a nodular parent material with approximately 75 percent of its cortex still present and has no evidence of heat treatment or patina.

The remaining complete core is classified as indeterminate in structure due to the minimal number of definitive negative flake scars, likely making the specimen a piece of angular debris with debatable cultural attributes. Similar to the other complete core, the specimen was found in TU 5 but at a much deeper elevation of 99.6-99.5 $\mathrm{m}$ (level 4). The specimen shows no sign of heat treatment but has a heavy patina.

The final core specimen is a bifacially worked core fragment recovered in Level 6 of TU 2 between 99.4 and $99.3 \mathrm{~m}$ in elevation. The fragment is rather large with maximum dimensions of $82-\mathrm{x}-43.4-\mathrm{x}-33.1 \mathrm{~mm}$. The core fragment shows no evidence of heat treatment and has no patina present.

\section{GROUNDSTONE}

One groundstone metate fragment was encountered in level 3 of TU 6, between $99.7 \mathrm{~m}$ and $99.6 \mathrm{~m}$ (Figure 6.5). The metate is made of siltstone and has two smooth grinding surfaces. The fragment is the rounded corner of a larger tabular groundstone of unknown dimensions. Although both sides appear utilized, one side displays more utilization with the presence of a slight depression sloping away from the rounded corner edges. The groundstone was found in association with seven pieces of debitage and two small pieces of burned limestone rock, just above the gravel lens in TU 6 .

\section{LITHIC DEBITAGE}

\section{Categories and Methods}

The amount of debitage recovered at site $41 \mathrm{KM} 225$ was relatively small considering the variety of lithic tools and the presence of a burned rock midden. Therefore, the analysis of the debitage was completed to describe general lithic assemblage descriptions, explore general lithic reduction strategies, and vertical displacement of artifacts at site 41KM225. To collect the data needed to address such issues, the debitage from site was sorted and quantified into four categories based on individual specimen attributes. The categories were derived from a combination of methods outlined by Andrefsky (1998) and Hiscock (2002). These categories consisted of complete flakes, proximal flakes, broken flakes, and flaking shatter.

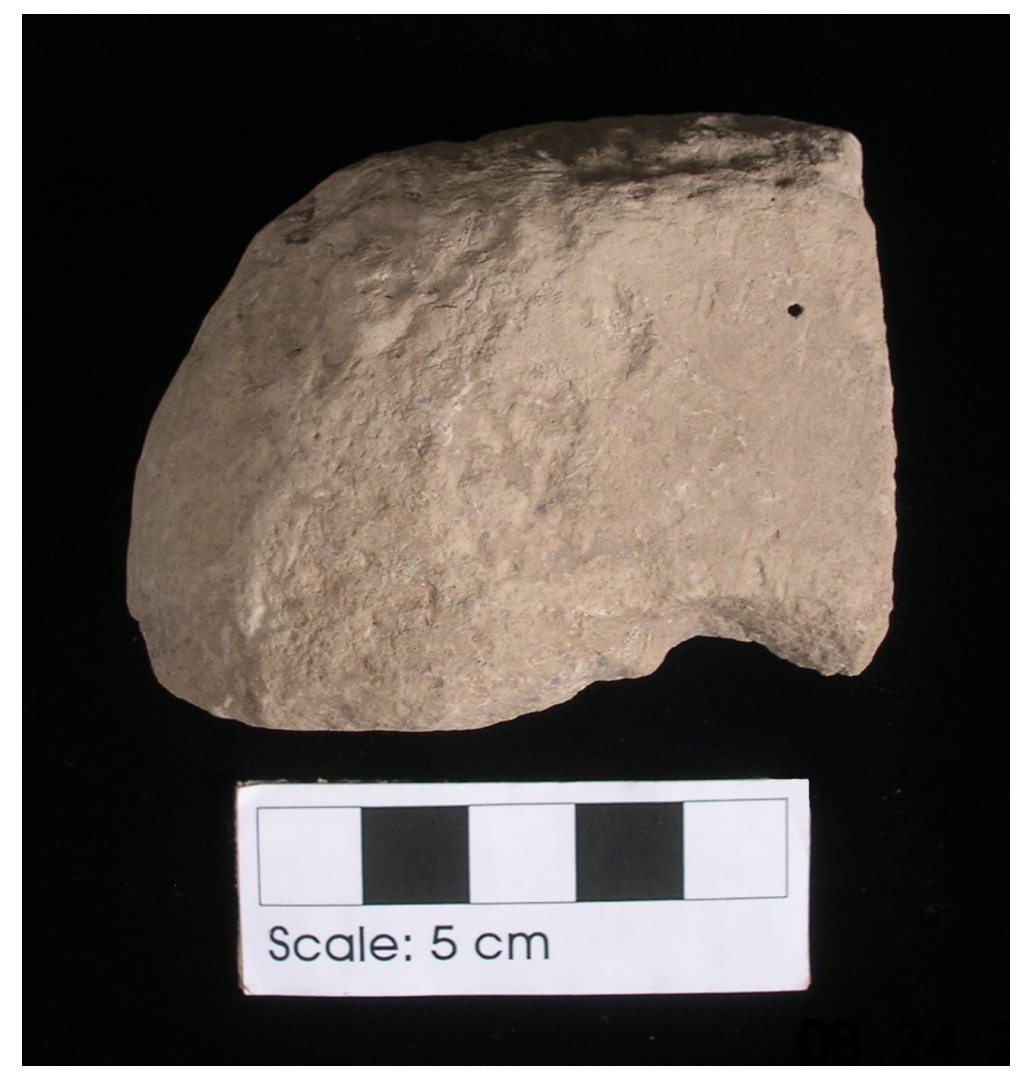

Figure 6.5. Groundstone fragment found in level 3 of TU 6 , between $99.7 \mathrm{~m}$ and $99.6 \mathrm{~m}$. 
Complete flakes are unbroken flakes that have a dorsal and ventral surface with an intact platform, termination, and unaltered margins. Proximal flake fragments are flakes that have an intact platform and bulb of percussion, but are missing a termination due to transverse breakage. Broken flakes are lateral, medial, or distal flake fragments that are identifiable as flakes by their dorsal and ventral surface. However, due to breakage, broken flakes are missing a platform. Flaking shatter are chipped stone artifacts produced from fracturing rock but due to breakage, weathering, or other taphonomic processes lacking enough attributes (e.g. dorsal/ventral surface, platform) to unambiguously be described as flake (complete or broken). Specimens exhibiting edge modification or possible use wear were culled and analyzed as modified flakes, discussed in the Informal Tools section.

The aim of this initial sort was to acquire information on the variety, physical condition, and distribution of the debitage assemblage (Table 6.4). In turn, the isolation of these categories allowed for the complete flakes to be subjected to a size-sort analysis. Using a methodology similar to that outlined in Henry et al. (1976), Stahle and Dunn (1982), and Ahler (1989), the assemblage of complete flakes was size sorted into seven size classes - from less than $10 \mathrm{~mm}$ to greater than $60 \mathrm{~mm}$ - for each unit/level. The objective of the size sort was to reveal patterns indicative of reduction strategies and vertical displacement of artifacts from post-depositional influences to establish the vertical integrity of the deposits. Drawing upon previous studies (Vierra 1997; Nickels 2000; and Nickels et al. 2003), the size-sort analysis will help in examining the vertical movement of artifacts through soil horizons.

Supplementing the size sort, a detailed individual flake analysis was conducted on the site's platform-bearing flakes (i.e., complete flakes and proximal flake fragments). This analysis aided in determining the lithic reduction strategies throughout the site. The individual flake analysis recorded five nominal attributes for each proximal or complete flake specimen. Nominal attributes included both technological and physical variables, including: flake type and subtype, raw material, percentage of dorsal cortex, and heat exposure.

The subtypes of complete flakes and proximal flake fragments consisted of core reduction flakes, biface thinning flakes, and tool resharpening flakes. A core reduction flake is generally a thicker flake with a large platform and cortex frequently on dorsal surface. These flakes are usually the result of hard hammer reduction. Biface thinning flakes are generally thinner flakes with a multifaceted or abraded platforms. Negative scars on the dorsal surface of these flakes are opposing and often overlap remnant flake scars. Tool resharpening flakes often exhibit use wear along the dorsal margin of the flake platform. These are difficult to identify and as such, none were identified on site 41KM225. And finally, indeterminate flakes are flakes that do not exhibit identifiable attributes or share any characteristics with the types listed above.

Overall, the above categories and attributes were chosen based on their potential to provide information on the lithic reduction strategies and vertical displacement of artifacts in site $41 \mathrm{KM} 225$. By identifying the individual flake attributes, inferences can be made on the reduction strategies present throughout the site. In addition, the size-sorting supported the mixed assemblage interpretation resulting from the field observations.

\section{SPECIAL SAMPLES}

Two special samples were collected, including one small charcoal sample and one soil matrix sample. The soil sample was taken from the ST 4 in Feature 1. The sample consisted of the dark 

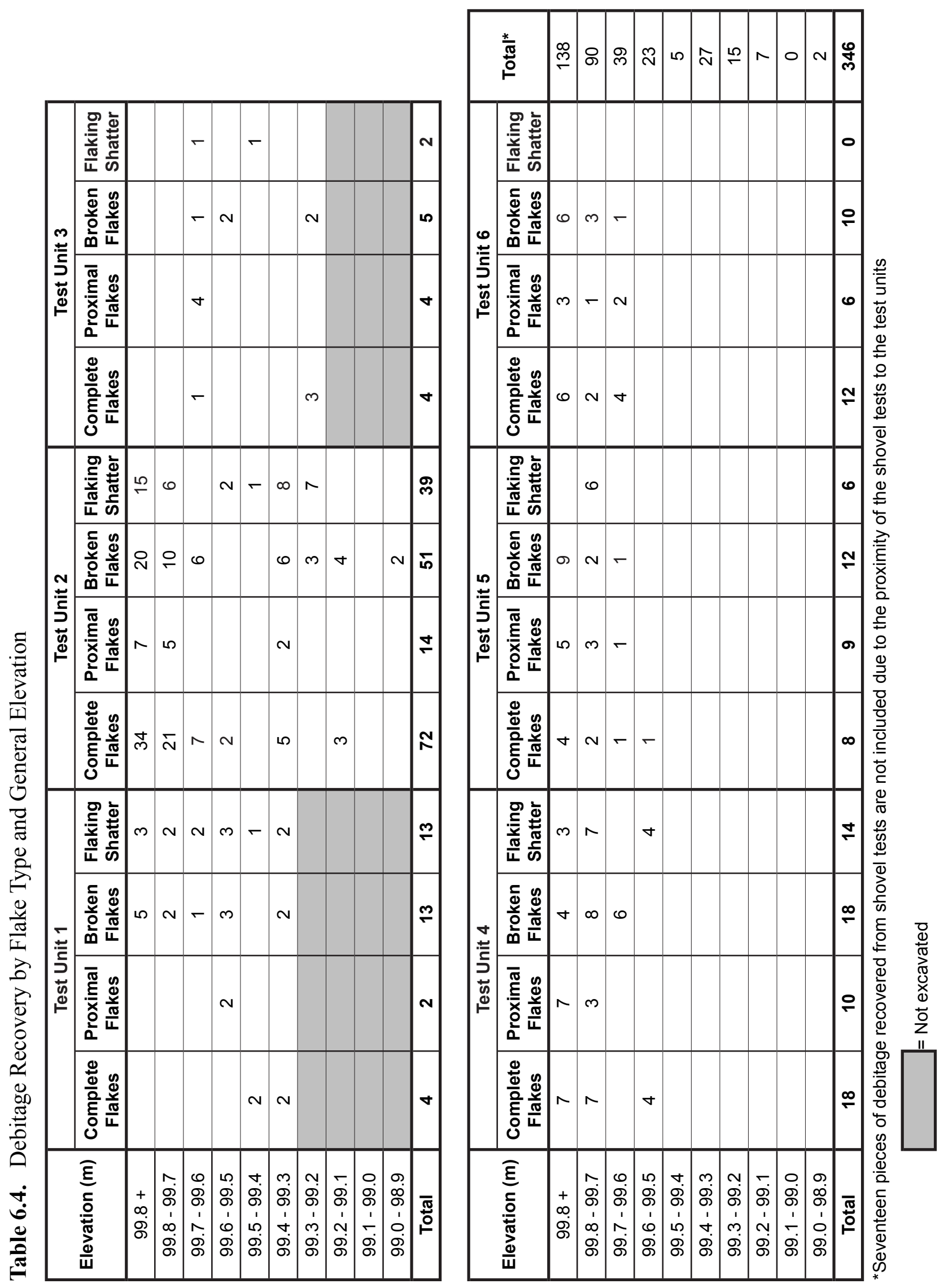
soil matrix of the feature from $20-40 \mathrm{cmbs}$. The charcoal sample was collected from TU 1, level 5 approximately $10 \mathrm{~cm}$ above the gravel lens. The charcoal was isolated in non-feature matrix. The radiocarbon testing returned a $2 \delta 1160-1270$ cal A.D. date that would place the deposits in the Late Prehistoric (Appendix B). This dating does not correlate with the diagnostic artifacts present and is further evidence to the interpretation that the site exhibits soil compression and bioturbation resulting in mixed assemblages and associated cultural components.

\section{Artifact Distributions}

As noted earlier, the primary intact deposit and highest artifact density occur in the upper two levels of excavation throughout the site, from 99.8-99.6 $\mathrm{m}$ in TU 3, 100.00-99.8 $\mathrm{m}$ in TU 2, and 99.9-99.7 $\mathrm{m}$ in TUs $1,4,5$, and 6 (Table 6.2). As displayed in the table, a marked reduction in recovered artifacts is observed below the first two levels. The ratio of artifacts from these upper layers in comparison to all the lower layers is approximately $1.3: 1$. In clarification, the upper $1.18 \mathrm{~m}^{3}$ excavated in the six test units recovered 206 artifacts, while the remaining $2.2 \mathrm{~m}^{3}$ recovered 157 artifacts. In addition, all the projectile points, formal tools, and all but one of the informal tools were recovered in the upper levels.

Horizontally, the highest artifact recovery came from TU 2, which was adjacent to TU 6 in the central portion of the western intact section of the site. However, the artifacts were almost equally distributed across the hilltop with a spike in artifact density in TUs 2 and 4, which are in close proximity to each other at the higher elevations of the hill. Density was calculated by taking the total amount of artifacts recovered in each unit and divided by the approximate total volume of soil excavated in each unit.
Of note, although the vertical placement of the diagnostic projectile points correlated with the chronological time periods attributed to each point, the returned date from the charcoal sample did not. The Paisano-like projectile point found on the surface is attributed to the Transitional Archaic, around 200 B.C. to A.D. $600(2,150-1,350$ B.P.). The Pedernales-like point, recovered in TU 2 between the surface and $99.8 \mathrm{~m}$ in elevation, is dated to the middle Late Archaic between 2000-350 B.C. (3,950-2,300 B.P.), depending on the source (Collins 2004; Turner and Hester 1993). The Early Triangular point, found at a slightly lower elevation of $99.77 \mathrm{~m}$ in TU 1, dates to the Middle Archaic, at 3700-3600 B.C. (roughly 5,650-5,550 B.P.). However, the charcoal sample was recovered in TU 1 between 99.5-99.4 $\mathrm{m}$ and had a date of $2 \delta 1160-1270$ cal A.D (790-680 B.P.), which puts it in the Late Prehistoric period. The discrepancy in dating can likely be attributed to the charcoal descending due to natural processes or being the remnants of a natural root burn. In addition, although the projectile points are in proper chronological order as far as depth of recovery, the diagnostic evidence shows 4,300 years of cultural materials compressed into approximately $25 \mathrm{~cm}$ of soil. 


\title{
Chapter 7
}

\section{Data Set for Comparative Literature Review}

\author{
Mindy Bonine and Michael Chavez
}

In order to place site $41 \mathrm{KM} 225$ into a wider regional prehistoric context, information from other archaeological sites in the surrounding area must first be compiled and synthesized into a usable form. A key step in this process is defining the limits of the research area; this determines what sites will be included in the analysis and those that will be excluded. The selection of specific types of data and data sets for comparative analysis will depend largely on the research questions asked and the focus of the analysis, whether it is based on time or space, be it macro-scale or micro-scale, or concentrating on particular site attributes. To this end, archaeologists generally use some form of geographic boundary to limit the research area. These limits have included political boundaries, such as current county or state limits; absolute distances, as in a measured radius around the site in question; physiographic limits, such as the Edwards Plateau region; or archaeologically defined prehistoric culture areas, as in the Central Texas archaeological region.

The research area defined for this analysis is based on topographic and hydrographic features in the Upper Llano River watershed. This research area includes all of the surface lands that drain water into the North Llano, from eastern Sutton County to northwest Kimble County, the South Llano, from northeast Edwards County (and parts of Real County) to southwest Kimble County, and the Llano River, from where these two tributaries meet in Junction to the confluence of the Llano and James Rivers in central Mason County (Figure 7.1). Portions of Menard and Kerr counties also drain into the Llano River between Junction and the James River. The Llano River watershed continues through Mason and Llano counties to end where the Llano River meets the Colorado River, but this section is not included in the research area, as will be explained below.

The decision to use the Upper Llano River watershed as a research area stems from a long established understanding that prehistoric inhabitants of the Central Texas archaeological region were organized into mobile hunter-gatherer groups that utilized a diversity of resources across the landscape. If, in fact, such groups concentrated their activities around a particular river basin and adjoining uplands, using resources from both lower and higher elevations, then a watershed-based research area would include most (if not all) of the possible locations inhabited by these groups. Therefore, a comparative analysis of sites in such a research area would help provide evidence for or against this relationship, and may lead to a realistic interpretation of settlement patterns, foraging strategies, and resource utilization (Binford 1980; Butzer 1982; Trigger 1967; Winterhalder and Smith 1981).

The research area was terminated at the confluence of the Llano and James rivers, instead of extending all the way to the Colorado River, to concentrate the comparative analysis on the landscape of the Edwards Plateau and areas just below it (the upper portion of the watershed), rather than include areas around the Colorado River where the topography and landscape have transitioned to the Texas Hill Country. However, it is understood that this is an arbitrary choice, and if the analysis of the current research area proves to be fruitful, an expansion of the research area to include this section of the Llano River watershed may be worthwhile. 


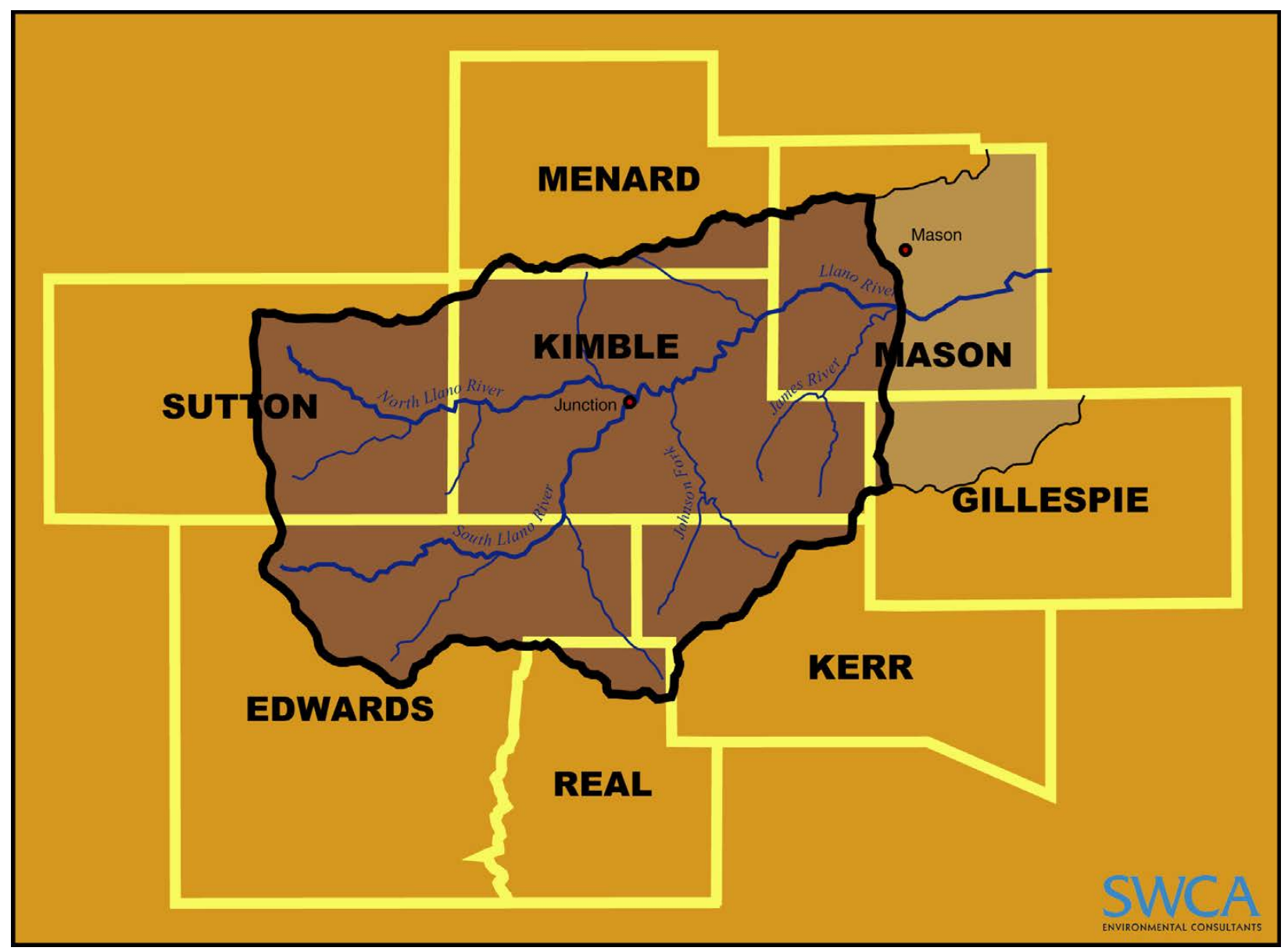

Figure 7.1. The Upper Llano River watershed research area.

In order to place 41KM225 in a broader historic context it was necessary to address two issues. The first was to gather and tabulate basic data of all of the previously recorded archaeological sites (as of May 2007) located in the Upper Llano River watershed research area. The purpose of gathering such data is to conduct a comparative analysis in order to determine if site $41 \mathrm{KM} 225$ is a typical site type (typology), located in a specific geographic area with similar or different site types (landscape), and if it was contemporaneous with other sites in the area (chronology). The second was to obtain information on a select number of tested archaeological sites in the research area, and conduct a comparative analysis of these sites and $41 \mathrm{KM} 225$. Again, the purpose is to see if what is known about 41KM225 is replicated in the archaeological record through the investiga- tion of other sites in the research area, using the same categories as the first study (i.e., typology, landscape, and chronology). A discussion of the results of the comparative analysis is presented in Chapter 8. The data used in that analysis is described below.

\section{Archaeological Sites in the UpPer Llano River Watershed}

To locate and tabulate all of the previously recorded sites in the Upper Llano River watershed research area, a large scale USGS 7.5 minute topographic map was printed of the research area, and the names of all the quadrangle sheets were compiled. An archaeological technician then accessed the Texas Archeological Sites Atlas (Atlas) to pull all of the recorded archaeo- 
logical site trinomials in each quadrangle sheet and enter these sites into a spreadsheet. The technician then completed the spreadsheet, recording the site type, landform, archaeological period, diagnostic tools, and features. Data for each site that was available on the Atlas was first completed, and all of the remaining data was researched from several trips to TARL to access their paper site files. In addition to the spreadsheet, the sites were plotted on the large scale map. A total of 311 sites were found in the Upper Llano River watershed research area; only four were not plotted on the Atlas or TARL maps and only five had no associated information at all. Ten of the 311 recorded sites were historicera sites with no prehistoric components.

The raw data retrieved from the Atlas and TARL site files within the research area was compiled over several decades, and numerous different forms containing different sorts of information were used throughout this time period. Additionally, the researchers used many different terms in describing sites (see below). The raw data replicated whatever information the forms and associated materials contained, and copied the same terminology from those forms. The only category where this was not the case is "landform." The archaeological technician utilized a preset list of terms to describe different landforms, and either matched them to the descriptions on the site forms, or made a determination based on the location of the site on the topographic maps. In general, the landform terms used here matched those on the site forms, but some minor adjustments were made. This was the most critical category to synthesize, as further analysis would sort the data based on these categories. Definitions of the terms used are below.

Hillslope: a topographic area that is sloping at an angle greater than 20 degrees, and typically much steeper, between a higher elevation and a lower one.
Hilltop: a topographic area that is the flattish upper surface of a hill. In the case of the Edwards Plateau, generally the top of the plateau near were it has been incised by drainages and other waterways.

Hilltop/Slope: a combination of both the hilltop and the hillslope. Sites found in these locations are generally eroding down from the upper elevations.

Terrace: a topographic area consisting of a relatively level bench or step-like surface breaking the continuity of a slope, generally located above a stream channel. Several terraces can be leading away from the channel.

Upland drainage: a topographic area consisting of a high elevation headwater drainage leading down towards larger waterways, and its associated "banks." Sites found in these locations are generally cradled within the V-shaped depression in the landscape.

Once the data for all the categories we recorded on the spreadsheet, the data was sorted by the "landform" category followed by "site type." Sites that did not have any associated locational information, no information at all, or were entirely historic-age, were removed from the analysis $(\mathrm{n}=19)$.

At this point some discussion of the reasons behind categorizing the data set by "landform," which is basically a topographic setting, is warranted. As described above, this study is taking a somewhat processual viewpoint in that prehistoric peoples made cultural adaptations based on their environmental conditions, including the straightforward action of exploiting whatever local resources can be found, and processing them at or near the places where they can be found. This includes choosing a campsite or habitation site best suited for a certain activity or series of activities, based on an environmental 
setting (e.g., topographic, floral and faunal, etc.). Sorting the data set by this category helps to link other site attributes to this concept of campsite choice and resource exploitation.

Once the site trinomials with no associated data (or were for historic sites) were removed from the data set, interpretation of the data set began. Over time, researchers have used different terms for similar sets of site attributes, from descriptions of features as in "burned rock midden sites," to a type of habitation area (implying both size and length of occupation) as in "campsite" or "village." The most diverse set of terminology was used for sites containing predominantly debitage and worked tools, including "lithic procurement," "lithic production," "lithic scatter," "lithic reduction," "workshop," or some combination thereof. These terms and others like them were synthesized into 14 total types, based on the incidence of related terms and a review of site attributes. A summary of all 292 sites used in the comparative analysis is presented in Tables 7.1-7.5.

\section{Tested Archaeological Sites in Kimble and Neighboring Counties}

\section{CRIteria For Comparative ANALYSIS}

Today, site testing has come to mean additional research in the form of site excavations and artifact analysis to answer specific research questions and determine if a site contains enough information to be significant, and thus eligible under Criterion D of the NRHP or for listing as an SAL. Several decades ago, when many of these sites were tested, specific eligibility recommendations were not generally made (or were not reported), and the value of the site was judged in more general terms. Nevertheless, for the purposes of this comparative analysis, the information provided in the testing reports is very helpful.
There are only 311 recorded sites in the Upper Llano River watershed, and there are even fewer investigated beyond the recording stage. Of the 311 sites in the study area, nine sites were chosen for the comprehensive comparative analysis based on minimal criteria. These criteria include: 1) sites within the research area investigated beyond the recordation stage through testing and have some sort of published account, and 2) sites that contained at least one burned rock midden. A second-tier criterion included temporal evidence of an Archaic period occupation that was a focus of the investigations. All but one of the sites met this criterion, and although no temporal evidence linked site 41KM90 to the Archaic, the fact that the two neighboring sites had Archaic period components may hint at its temporal association. Each site used in the analysis is described below, and a summary is presented in Table 7.6.

Of note, the Buckhollow Site (41KM16) was not chosen based on the limited investigations into the Late Archaic component found in a buried paleosol throughout the site. The site is mentioned here based on the exhaustive study carried out by the investigations on the Late Prehistoric component of the site (more specifically related to the Toyah Phase). The research conducted on this Late Prehistoric component is a leading resource for study into the lifeways of the Toyah people in the western Edwards Plateau and southern Great Plains. However, the limited amount of data available on the Late Archaic component prevents the site from being included in this study.

\section{RED CREEK SITE (41KM3)}

The Red Creek Site (41KM3) is located on a terrace overlooking the confluence of Red Creek and the Llano River in Kimble County, about 11.5 miles north-northeast of 41KM225 (Henderson 1997). The Red Creek Site lies just north of the confluence of the two rivers, where Red 
Table 7.1. Previously Recorded Archaeological Sites on Hillslopes

\begin{tabular}{|c|c|c|c|c|c|}
\hline Site & Site Type & Landform & $\begin{array}{c}\text { Archaeological } \\
\text { Periods }\end{array}$ & Diagnostic Tools & Features \\
\hline $41 \mathrm{MS} 4$ & Burial & Hillslope & Not Reported & $\begin{array}{c}\text { Projectile Points Types } \\
\text { Not Reported }\end{array}$ & Burial \\
\hline 41KM159 & Burned Rock Midden & Hillslope & Early Archaic & Nolan and Gower & Burned Rock Midden \\
\hline 41SU20 & Burned Rock Midden & Hillslope & Not Reported & Not Reported & Burned Rock Midden \\
\hline 41SU13 & Burned Rock Midden & Hillslope & Not Reported & Not Reported & Burned Rock Midden \\
\hline 41SU14 & Burned Rock Midden & Hillslope & Not Reported & Not Reported & Burned Rock Midden \\
\hline $41 \mathrm{KM} 160$ & Burned Rock Midden & Hillslope & Unknown & None & Burned Rock Midden \\
\hline 41KM141 & Burned Rock Midden & Hillslope & Unknown & None & Burned Rock Midden \\
\hline 41SU10 & Burned Rock Midden & Hillslope & Unknown & Not Reported & Burned Rock Midden \\
\hline 41SU16 & Burned Rock Midden & Hillslope & Unknown & Not Reported & Burned Rock Midden \\
\hline 41SU7 & Burned Rock Midden & Hillslope & Unknown & None & Burned Rock Midden \\
\hline 41SU9 & Burned Rock Midden & Hillslope & Unknown & None & Burned Rock Midden \\
\hline 41SU8 & Burned Rock Midden & Hillslope & Unknown & None & Burned Rock Midden \\
\hline 41KM30 & Burned Rock Midden & Hillslope & Unknown & None & Burned Rock Midden \\
\hline $41 \mathrm{KM} 137$ & Lithic Procurement/Production & Hillslope & Early to Mid Archaic & $\begin{array}{c}\text { Plainview, Stemmed, and } \\
\text { Corner-notched }\end{array}$ & None \\
\hline $41 \mathrm{KM} 48$ & Lithic Procurement/Production & Hillslope & Unknown & None & None \\
\hline $41 \mathrm{KM} 49$ & Lithic Procurement/Production & Hillslope & Unknown & None & None \\
\hline $41 S U 46$ & Lithic Procurement/Production & Hillslope & Unknown & Not Reported & None \\
\hline $41 \mathrm{KM} 49$ & Lithic Procurement/Production & Hillslope & Unknown & None & None \\
\hline 41KM130 & Lithic Procurement/Production & Hillslope & Unknown & None & Scattered Burned Rock \\
\hline 41KM58 & Lithic Procurement/Production & Hillslope & Unknown & Not Reported & Not Reported \\
\hline 41KM121 & Lithic Procurement/Production & Hillslope & Unknown & Point Base & None \\
\hline 41KR234 & Lithic Procurement/Production & Hillslope & Unknown & None & None \\
\hline $41 \mathrm{KM} 74$ & Lithic Procurement/Production & Hillslope & Unknown & None & None \\
\hline $41 \mathrm{KM} 42$ & Lithic Procurement/Production & Hillslope & Unknown & None & None \\
\hline $41 \mathrm{KM} 43$ & Lithic Procurement/Production & Hillslope & Unknown & None & None \\
\hline $41 \mathrm{SU} 48$ & Lithic Procurement/Production & Hillslope & Unknown & Not Reported & Not Reported \\
\hline 41SU41 & Lithic Procurement/Production & Hillslope & Unknown & None & None \\
\hline 41SU42 & Lithic Procurement/Production & Hillslope & Unknown & None & None \\
\hline 41KM86 & Lithic Procurement/Production & Hillslope & Unknown & None & None \\
\hline $41 \mathrm{KM} 173$ & Lithic Procurement/Production & Hillslope & Unknown & None & None \\
\hline 41KM176 & Lithic Procurement/Production & Hillslope & Unknown & None & None \\
\hline $41 \mathrm{KM} 177$ & Lithic Procurement/Production & Hillslope & Unknown & None & None \\
\hline 41KM178 & Lithic Procurement/Production & Hillslope & Unknown & None & None \\
\hline $41 \mathrm{KM} 180$ & Lithic Procurement/Production & Hillslope & Unknown & None & None \\
\hline 41KM181 & Lithic Procurement/Production & Hillslope & Unknown & None & None \\
\hline $41 \mathrm{KM} 183$ & Lithic Procurement/Production & Hillslope & Unknown & None & None \\
\hline 41KM193 & Lithic Procurement/Production & Hillslope & Unknown & None & None \\
\hline 41KM196 & Lithic Procurement/Production & Hillslope & Unknown & None & None \\
\hline 41KM197 & Lithic Procurement/Production & Hillslope & Unknown & None & None \\
\hline 41SU39 & Lithic Procurement/Production & Hillslope & Unknown & None & None \\
\hline $41 \mathrm{SU} 40$ & Lithic Procurement/Production & Hillslope & Unknown & None & None \\
\hline $41 \mathrm{KM} 191$ & Lithic Scatter & Hillslope & Middle-Late Archaic & Reworked Dart Point & None \\
\hline
\end{tabular}




\section{7-6 Chapter 7}

Table 7.1. Previously Recorded Archaeological Sites on Hillslopes, continued

\begin{tabular}{|c|c|c|c|c|c|}
\hline Site & Site Type & Landform & $\begin{array}{c}\text { Archaeological } \\
\text { Periods }\end{array}$ & Diagnostic Tools & Features \\
\hline 41KM88 & Lithic Scatter & Hillslope & Unknown & None & None \\
\hline 41KM75 & Lithic Scatter & Hillslope & Unknown & None & None \\
\hline $41 \mathrm{KM} 76$ & Lithic Scatter & Hillslope & Unknown & Possible Frio Points & None \\
\hline $41 \mathrm{KM} 45$ & Lithic Scatter & Hillslope & Unknown & None & None \\
\hline 41KM118 & Lithic Scatter & Hillslope & Unknown & None & None \\
\hline 41SU45 & Lithic Scatter & Hillslope & Unknown & Not Reported & None \\
\hline 41SU49 & Lithic Scatter & Hillslope & Unknown & Not Reported & None \\
\hline 41SU54 & Lithic Scatter & Hillslope & Unknown & None & None \\
\hline 41KM227 & Lithic Scatter & Hillslope & Unknown & None & None \\
\hline $41 \mathrm{KM} 228$ & Lithic Scatter & Hillslope & Unknown & None & None \\
\hline 41KM122 & Lithic Scatter & Hillslope & Unknown & None & None \\
\hline 41KM190 & Lithic Scatter & Hillslope & Unknown & None & None \\
\hline 41KM172 & Lithic Scatter & Hillslope & Unknown & None & None \\
\hline 41KM100 & Lithic Scatter & Hillslope & Unknown & None & Burned Rock Cluster \\
\hline $41 \mathrm{MS} 35$ & Not Reported & Hillslope & Not Reported & Not Reported & Not Reported \\
\hline $41 \mathrm{MS} 42$ & Not Reported & Hillslope & Not Reported & Not Reported & Not Reported \\
\hline 41MS58 & Not Reported & Hillslope & Not Reported & Not Reported & Not Reported \\
\hline $41 \mathrm{MS} 46$ & Not Reported & Hillslope & Not Reported & Not Reported & Not Reported \\
\hline 41KM198 & Not Reported & Hillslope & Not Reported & Not Reported & Not Reported \\
\hline 41KM107 & Not Reported & Hillslope & Not Reported & Not Reported & Not Reported \\
\hline 41KM108 & Not Reported & Hillslope & Not Reported & Not Reported & Not Reported \\
\hline 41KM109 & Not Reported & Hillslope & Not Reported & Not Reported & Not Reported \\
\hline 41KM101 & Not Reported & Hillslope & Not Reported & Not Reported & Not Reported \\
\hline 41KM102 & Not Reported & Hillslope & Not Reported & Not Reported & Not Reported \\
\hline $41 \mathrm{KM} 103$ & Not Reported & Hillslope & Not Reported & Not Reported & Not Reported \\
\hline 41KM104 & Not Reported & Hillslope & Not Reported & Not Reported & Not Reported \\
\hline $41 \mathrm{KM} 106$ & Not Reported & Hillslope & Not Reported & Not Reported & Not Reported \\
\hline 41KM113 & Not Reported & Hillslope & Not Reported & Not Reported & Not Reported \\
\hline 41KM111 & Not Reported & Hillslope & Not Reported & Not Reported & Not Reported \\
\hline $41 \mathrm{KM} 112$ & Not Reported & Hillslope & Not Reported & Not Reported & Not Reported \\
\hline 41KM110 & Not Reported & Hillslope & Not Reported & Not Reported & Not Reported \\
\hline $41 \mathrm{KM} 127$ & Not Reported & Hillslope & Not Reported & Not Reported & Not Reported \\
\hline 41KM201 & Not Reported & Hillslope & Note Reported & Not Reported & Not Reported \\
\hline $41 \mathrm{KM} 132$ & Open Campsite & Hillslope & Late Archaic & Ensor & None \\
\hline 41KM134 & Open Campsite & Hillslope & Unknown & None & None \\
\hline $41 \mathrm{SU} 43$ & $\begin{array}{c}\text { Open Campsite/Burned Rock } \\
\text { Midden }\end{array}$ & Hillslope & Early-Middle Archaic & $\begin{array}{c}\text { Projectile Points Types Not } \\
\text { Reported }\end{array}$ & Burned Rock Midden \\
\hline $41 \mathrm{KM} 188$ & $\begin{array}{c}\text { Open Campsite/Lithic Scatter/ } \\
\text { Procurement }\end{array}$ & Hillslope & Unknown & None & None \\
\hline $41 \mathrm{KM} 105$ & $\begin{array}{c}\text { Open Campsite/Lithic Scatter/ } \\
\text { Procurement }\end{array}$ & Hillslope & Unknown & None & None \\
\hline $41 \mathrm{KM} 133$ & Open Campsite/Procurement & Hillslope & Unknown & None & Lithic Workshop \\
\hline $41 \mathrm{KM} 213$ & $\begin{array}{c}\text { Lithic Procurement/Burned Rock } \\
\text { Midden }\end{array}$ & Hillslope & Unknown & None & Burned Rock Midden \\
\hline
\end{tabular}


Table 7.1. Previously Recorded Archaeological Sites on Hillslopes, continued

\begin{tabular}{|c|c|c|c|c|c|}
\hline Site & Site Type & Landform & $\begin{array}{c}\text { Archaeological } \\
\text { Periods }\end{array}$ & Diagnostic Tools & Features \\
\hline $41 \mathrm{KM} 216$ & $\begin{array}{c}\text { Lithic Procurement/Burned Rock } \\
\text { Midden }\end{array}$ & Hillslope & Middle-Late Archaic & Marshall and Palmillas & Hearth \\
\hline $41 \mathrm{MS} 2$ & Pictographs & Hillslope & Not Reported & Not Reported & Not Reported \\
\hline $41 \mathrm{KM} 60$ & Quarry & Hillslope & Not Reported & Not Reported & Not Reported \\
\hline $41 \mathrm{KM} 63$ & Quarry & Hillslope & Not Reported & Not Reported & Not Reported \\
\hline $41 \mathrm{KM} 158$ & Rock Shelter & Hillslope & $\begin{array}{c}\text { Historic and Unknown } \\
\text { Prehistoric }\end{array}$ & None & $\begin{array}{c}\text { Metate and Historic } \\
\text { Dump }\end{array}$ \\
\hline $41 \mathrm{KM} 140$ & Sinkhole Burial & Hillslope & Unknown & None & Burial \\
\hline $41 \mathrm{KR} 241$ & Sinkhole Cemetery & Hillslope & Use: $7500-1750 \mathrm{BP}$ & Dart Points and Beads & Cemetery \\
\hline
\end{tabular}

Creek makes a turn from a north-south orientation to an east-west orientation, before turning once again north-south to empty into the Llano River. The site is approximately $7-8$ acres in size or roughly $300 \mathrm{~m}$ long by at least $100 \mathrm{~m}$ wide. A large quantity of prehistoric cultural material was visible on the surface of the terrace, including at least two burned rock middens and several hearths. Chipped stone material was also visible on the surface. The site is located in an area that was going to be impacted by the development of FM 3480, and it was investigated by the SDHPT in 1988. Investigations were conducted to determine if the site was significant, and it has since been designated as an SAL.

Researchers investigated only those portions of the site within the public ROW, but it was clear that the site extended far beyond the investigated area to the north. The archaeological investigation of the site revealed that the bulk of the cultural material within the ROW was located on the top and initial slope of the terrace on a deflated surface with minimal depth of deposits. These areas suffered from extensive denuding, resulting in a degraded surface and mixed archaeological components (Henderson 1997). However, there was some evidence that although the depth of deposits was minimal, the horizontal distribution of artifacts and features could be separated into different occupation episodes. Researchers determined the site was occupied from the Late Paleoindian through Late
Prehistoric, with the bulk of the material from the Middle Archaic. These occupation dates were derived from the diagnostic points found at the site (Angostura-like, early stemmed, Andice, Bell, side-notched, Bulverde-like, Nolan, Travis-like, Nolan/Travis family, Pedernales, contracting-stemmed, straight-stemmed, Montell, Marcos, and miscellaneous dart points), and the chronology developed by Weir (1976) and Prewitt (1981). Unfortunately, no radiocarbon samples were taken and no absolute dates were produced for the site. Table 7.7 summarizes the researcher's chronology.

Interestingly, several of the excavated features appeared to be predominantly intact, including Feature 3, a burned rock midden with a mounded appearance which contained a disturbed surface layer of rock over an undisturbed subsurface; Feature 4, a circular burned rock midden of good preservation with only a single layer of rock showing on the surface; Feature 5, a hearth likely associated with Feature 4; and Feature 7, a large basin-shaped hearth with dark ashy soil within the hearthstones which was partially excavated in 1988 (Henderson 1997). All of these features were seen at or near the surface, and the excavations were limited to determining the level of preservation of the subsurface material. Several diagnostic artifacts were found associated with several of the features, but investigators did not conduct a full detailed artifact analysis of the recovered lithic material as it was evident 


\section{7-8 Chapter 7}

Table 7.2. Previously Recorded Archaeological Sites on Hilltops

\begin{tabular}{|c|c|c|c|c|c|}
\hline Site & Site Type & Landform & $\begin{array}{c}\text { Archaeological } \\
\text { Periods }\end{array}$ & Diagnostic Tools & Features \\
\hline $41 \mathrm{KM} 36$ & Quarry & Hilltop & Unknown & None & None \\
\hline $41 \mathrm{KM} 207$ & Lithic Scatter & Hilltop & Unknown & None & None \\
\hline 41KR471 & Lithic Scatter & Hilltop & Unknown & None & None \\
\hline $41 \mathrm{KM} 40$ & Lithic Scatter & Hilltop & Unknown & None & Burned Rock Scatter \\
\hline 41SU44 & Lithic Scatter & Hilltop & Unknown & None & None \\
\hline $41 S U 47$ & Lithic Scatter & Hilltop & Unknown & Not Reported & None \\
\hline 41KM171 & Lithic Scatter & Hilltop & Unknown & None & None \\
\hline $41 \mathrm{KM} 174$ & Lithic Scatter & Hilltop & Unknown & None & None \\
\hline $41 \mathrm{KM} 175$ & Lithic Scatter & Hilltop & Unknown & None & None \\
\hline 41KM192 & Lithic Scatter & Hilltop & Unknown & None & None \\
\hline $41 \mathrm{KM} 10$ & Lithic Scatter & Hilltop & Unknown & None & None \\
\hline $41 \mathrm{KM} 72$ & Lithic Scatter & Hilltop & Unknown & None & None \\
\hline 41SU52 & Lithic Scatter & Hilltop & Unknown & None & None \\
\hline $41 \mathrm{KM} 87$ & Lithic Procurement/Production & Hilltop & Unknown & None & None \\
\hline $41 \mathrm{KM} 170$ & Lithic Procurement/Production & Hilltop & Unknown & None & None \\
\hline 41KM182 & Lithic Procurement/Production & Hilltop & Unknown & None & None \\
\hline 41KM189 & Lithic Procurement/Production & Hilltop & Unknown & None & None \\
\hline 41KM194 & Lithic Procurement/Production & Hilltop & Unknown & None & None \\
\hline 41KM185 & Lithic Procurement/Production & Hilltop & Unknown & None & None \\
\hline 41KM186 & Lithic Procurement/Production & Hilltop & Unknown & None & None \\
\hline 41KM187 & Lithic Procurement/Production & Hilltop & Unknown & None & None \\
\hline $41 \mathrm{KM} 145$ & Lithic Procurement/Production & Hilltop & Unknown & None & None \\
\hline 41KM119 & Lithic Procurement/Production & Hilltop & Unknown & None & None \\
\hline $41 \mathrm{MS} 44$ & Not Reported & Hilltop & Not Reported & Not Reported & Not Reported \\
\hline $41 \mathrm{MS} 45$ & Not Reported & Hilltop & Not Reported & Not Reported & Not Reported \\
\hline $41 \mathrm{MS} 36$ & Not Reported & Hilltop & Not Reported & Not Reported & Not Reported \\
\hline $41 \mathrm{MS} 34$ & Not Reported & Hilltop & Not Reported & Not Reported & Not Reported \\
\hline $41 \mathrm{MS} 45$ & Not Reported & Hilltop & Not Reported & Not Reported & Not Reported \\
\hline $41 \mathrm{MS} 40$ & Not Reported & Hilltop & Not Reported & Not Reported & Not Reported \\
\hline 41KM202 & Not Reported & Hilltop & Not Reported & Not Reported & Not Reported \\
\hline 41KM131 & Open Campsite & Hilltop & Middle-Early Archaic & $\begin{array}{c}\text { Pedernales, Angostura, } \\
\text { and Frio }\end{array}$ & None \\
\hline 41KM138 & Open Campsite & Hilltop & Unknown & None & Hearth \\
\hline $41 \mathrm{KM} 39$ & Open Campsite & Hilltop & Unknown & None & Possible Hearth \\
\hline 41KM195 & $\begin{array}{c}\text { Open Campsite/Lithic } \\
\text { Procurement }\end{array}$ & Hilltop & Unknown & None & None \\
\hline 41KM38 & $\begin{array}{c}\text { Open Campsite/Lithic } \\
\text { Procurement }\end{array}$ & Hilltop & Unknown & None & None \\
\hline 41KM64 & Burned Rock Midden/Quarry & Hilltop & Archaic & None & Burned Rock Midden \\
\hline 41SU11 & Rockshelter & Hilltop & Not Reported & Not Reported & $\begin{array}{l}\text { Pictograph and } \\
\text { Petroglyph }\end{array}$ \\
\hline
\end{tabular}


Table 7.3. Previously Recorded Archaeological Sites on Hilltop/Hillslopes

\begin{tabular}{|c|c|c|c|c|c|}
\hline Site & Site Type & Landform & $\begin{array}{c}\text { Archaeological } \\
\text { Periods }\end{array}$ & Diagnostic Tools & Features \\
\hline $41 \mathrm{MS} 54$ & Quarry & Hilltop/Slope & Unknown & None & None \\
\hline $41 \mathrm{KM} 52$ & Quarry & Hilltop/Slope & Unknown & None & $\begin{array}{c}\text { Not Re- } \\
\text { ported }\end{array}$ \\
\hline $41 \mathrm{KM} 41$ & $\begin{array}{c}\text { Lithic Procurement/Produc- } \\
\text { tion }\end{array}$ & Hilltop/Slope & Unknown & None & None \\
\hline $41 \mathrm{KM} 44$ & $\begin{array}{c}\text { Lithic Procurement/Produc- } \\
\text { tion }\end{array}$ & Hiltop/Slope & Unknown & None & None \\
\hline
\end{tabular}

that several pieces were damaged by road construction and maintenance, and were additionally mixed by erosion and deflation. Thus, an identification of formal and informal tools was conducted (and therefore used to determine the dates of occupation at the site), while the remaining debitage was counted to calculate the volume of material recovered. A preservation plan was instituted that buried the site within the ROW to preserve it for future researchers.

\section{SITE 41KM61}

Site 41KM61 is located along the western bank of the James River along a series of terraces forming a formidable ridgeline above the river, about 12 miles east-southeast of 41KM225 (Young 1986). The site is located on an early pioneer ranch in Kimble County, and the area had been used as a pasture for many years. Surface collection of the site had been conducted over several decades, but still over 55 dart points and numerous bifaces and scrapers were recovered during the test excavations. Cultural material extended over a very large area, 40-50 acres, but only four surface features were located, two circular burned rock middens and two hearths. The site appeared to cover most horizontal surfaces on at least three terraces above the James River, but erosion and flood events had impacted the placement of many of the artifacts up and down slope.
A transportation project was to bisect the site, and SDHPT conducted test excavations within the ROW in the winter of 1980, including portions of the two hearths. The proposed ROW appeared to be located in an area between two separate occupations of the late Middle Archaic: a Round Rock Phase and a later San Marcos Phase (Young 1986:9-10). Several excavation units showed the site was badly disturbed and lacked discrete stratigraphic zones, with black clay soils about $30 \mathrm{~cm}$ thick over bedrock. Several instances of historic period artifacts under prehistoric period artifacts provided the evidence for this disturbance. Projectile points from the Archaic period into the Neo-American period were recovered from the surface of the entirety of the site (Pedernales, Frio, Montell, Marshall, Castroville, Bell, Marcos, Ensor, Ensor-Frio variant, Williams-like, Edgewood, Travis, Bulverde, untyped corner-notched dart points, Perdiz, and Alba-like); however, the features could not be placed within a particular time period. Researchers concluded that the tested areas did not retain sufficient integrity to merit inclusion to the NRHP or listing as an SAL.

Researchers also utilized Weir (1976) as the foundation for their cultural chronology, which is summarized in Table 7.8. They list several radiocarbon dates to support the chronological sequence, adapted from Weir (1976), along with their associated projectile point types. Unfortunately, no radiocarbon dates were attributed to site $41 \mathrm{KM} 61$ to tie into the established sequence. 
Table 7.4. Previously Recorded Archaeological Sites on Terraces

\begin{tabular}{|c|c|c|c|c|c|}
\hline Site & Site Type & Landform & $\begin{array}{c}\text { Archaeological } \\
\text { Periods }\end{array}$ & Diagnostic Tools & Features \\
\hline $41 \mathrm{MS} 25$ & Bruned Rock Midden & Terrace & Not Reported & Not Reported & Burned Rock Mound \\
\hline 41KM11 & Burned Rock Midden & Terrace & Not Reported & Frio & Scattered Burned Rock \\
\hline 41KM51 & Burned Rock Midden & Terrace & Archaic & Archaic Dart Point & $\begin{array}{c}\text { Possible Burned Rock } \\
\text { Midden }\end{array}$ \\
\hline 41KM57 & Burned Rock Midden & Terrace & Archaic & None & Burned Rock Midden \\
\hline $41 \mathrm{KM} 148$ & Burned Rock Midden & Terrace & Early Archaic & Bulverde & Burned Rock Midden \\
\hline $41 \mathrm{KM} 143$ & Burned Rock Midden & Terrace & Late Archaic & Marcos & Burned Rock Midden \\
\hline 41SU19 & Burned Rock Midden & Terrace & $\begin{array}{l}\text { Late Archaic/Late Prehis- } \\
\text { toric }\end{array}$ & $\begin{array}{l}\text { Dart and Arrow Points } \\
\text { Types Not Reported }\end{array}$ & $\begin{array}{l}\text { Burned Rock Midden } \\
\text { and Hearth }\end{array}$ \\
\hline $41 \mathrm{MS} 22$ & Burned Rock Midden & Terrace & Late Prehistoric & $\begin{array}{c}\text { Projectile Points Types Not } \\
\text { Reported }\end{array}$ & Burned Rock Midden \\
\hline $41 \mathrm{KM} 215$ & Burned Rock Midden & Terrace & Middle Archaic & Travis & $\begin{array}{l}\text { Burned Rock Midden } \\
\text { and Mortar Holes }\end{array}$ \\
\hline 41KM17 & Burned Rock Midden & Terrace & Not Reported & Marshall & Burned Rock Midden \\
\hline $41 \mathrm{KM} 24$ & Burned Rock Midden & Terrace & Not Reported & $\begin{array}{c}\text { Projectile Point Fragments } \\
\text { Types Not Reported }\end{array}$ & $\begin{array}{c}\text { Scattered Burned Rock } \\
\text { Midden }\end{array}$ \\
\hline 41KM19 & Burned Rock Midden & Terrace & Not Reported & Dart Point Fragments & Burned Rock Midden \\
\hline 41MS69 & Burned Rock Midden & Terrace & Unknown & None & Burned Rock Midden \\
\hline $41 \mathrm{KM} 210$ & Burned Rock Midden & Terrace & Unknown & None & Burned Rock Midden \\
\hline 41KM142 & Burned Rock Midden & Terrace & Unknown & None & Burned Rock Midden \\
\hline 41KM161 & Burned Rock Midden & Terrace & Unknown & None & $\begin{array}{l}\text { Burned Rock Midden } \\
\text { and Hearths }\end{array}$ \\
\hline $41 \mathrm{KM} 68$ & Burned Rock Midden & Terrace & Archaic & None & Burned Rock Midden \\
\hline $41 \mathrm{KM} 136$ & Burned Rock Midden & Terrace & Unknown & None & Burned Rock Midden \\
\hline 41KM69 & Burned Rock Midden & Terrace & Unknown & None & Burned Rock Midden \\
\hline 41KM223 & Burned Rock Midden & Terrace & Early-Middle Archaic & Bulverde & $\begin{array}{l}\text { Hearth/Burned Rock } \\
\text { Midden }\end{array}$ \\
\hline 41KM179 & Burned Rock Midden & Terrace & Unknown & None & Burned Rock Midden \\
\hline $41 \mathrm{KM} 7$ & Burned Rock Midden & Terrace & Archaic & Gary-like & Burned Rock Midden \\
\hline 41KM114 & Burned Rock Midden & Terrace & Early-Middle Archaic & $\begin{array}{l}\text { Martindale, Andice, Bell- } \\
\text { like, Early Triangular, } \\
\text { Nolan, Bulverde, and } \\
\text { Pedernales }\end{array}$ & $\begin{array}{c}\text { Burned Rock Midden/ } \\
\text { Hearth }\end{array}$ \\
\hline 41KM124 & Burned Rock Midden & Terrace & $\begin{array}{l}\text { Late Prehistoric-Middle } \\
\text { Archaic }\end{array}$ & $\begin{array}{c}\text { Perdiz and Scallorn Like } \\
\text { Arrow Point }\end{array}$ & $\begin{array}{l}\text { Burned Rock Midden } \\
\text { and Hearths }\end{array}$ \\
\hline 41KR229 & Burned Rock Midden & Terrace & Middle-Late Archaic & Late Archaic Dart Points & Burned Rock Midden \\
\hline 41KM128 & Burned Rock Midden & Terrace & Possible Middle Archaic & None & $\begin{array}{l}\text { Burned Rock Midden } \\
\text { and Possible Hearth }\end{array}$ \\
\hline $41 \mathrm{MS} 33$ & Burned Rock Midden & Terrace & $\begin{array}{l}\text { Possibly Early-Middle } \\
\text { Archaic }\end{array}$ & Not Reported & $\begin{array}{l}\text { Burned Rock Midden } \\
\text { and Possible Hearth }\end{array}$ \\
\hline 41KM139 & Burned Rock Midden & Terrace & Unknown & None & $\begin{array}{l}\text { Possible Burned Rock } \\
\text { Midden in Area }\end{array}$ \\
\hline 41KM139 & Burned Rock Midden & Terrace & Unknown & None & Burned Rock Midden \\
\hline $41 \mathrm{KM} 214$ & Burned Rock Midden & Terrace & Early-Late Archaic & Pedernales and Nolan & $\begin{array}{l}\text { Hearth/Burned Rock } \\
\text { Midden }\end{array}$ \\
\hline $41 \mathrm{MS} 28$ & Burned Rock Midden & Terrace & Archaic/Late Prehistoric & $\begin{array}{l}\text { Arrow and Dart Points } \\
\text { Types Not Reported }\end{array}$ & $\begin{array}{l}\text { Burned Rock Midden/ } \\
\text { Bedrock Mortar }\end{array}$ \\
\hline
\end{tabular}


Table 7.4. Previously Recorded Archaeological Sites on Terraces, continued

\begin{tabular}{|c|c|c|c|c|c|}
\hline Site & Site Type & Landform & $\begin{array}{l}\text { Archaeological } \\
\text { Periods }\end{array}$ & Diagnostic Tools & Features \\
\hline 41KM146 & Burned Rock Midden & Terrace & Early-Late Archaic & $\begin{array}{c}\text { Nolan, Langtry, Bulverde, } \\
\text { Pedernales, Marcos, and } \\
\text { Montell }\end{array}$ & $\begin{array}{l}\text { Burned Rock Middens } \\
\text { and Mortar Holes }\end{array}$ \\
\hline $41 \mathrm{KM} 208$ & Burned Rock Midden & Terrace & $\begin{array}{c}\text { Early-Late Archaic/Late } \\
\text { Prehistoric/Neo-American/ } \\
\text { Historic }\end{array}$ & Not Reported & $\begin{array}{c}\text { Burned Rock Midden/ } \\
\text { Hearth }\end{array}$ \\
\hline 41KM152 & Burned Rock Midden & Terrace & Early-Middle Archaic & Nolan & $\begin{array}{c}\text { Burned Rock Midden, } \\
\text { Hearths, and Shell Con- } \\
\text { centration }\end{array}$ \\
\hline 41KM153 & Burned Rock Midden & Terrace & $\begin{array}{c}\text { Late Archaic/Late Prehis- } \\
\text { toric/Neo-American }\end{array}$ & $\begin{array}{c}\text { Edgewood and Possible } \\
\text { Guadalupe Tool }\end{array}$ & $\begin{array}{l}\text { Burned Rock Midden } \\
\text { and Hearths }\end{array}$ \\
\hline $41 \mathrm{KM} 217$ & Burned Rock Midden & Terrace & $\begin{array}{c}\text { Late Archaic/Late Prehis- } \\
\text { toric/Neo-American }\end{array}$ & $\begin{array}{l}\text { Ensor, Perdiz, and Ed- } \\
\text { wards }\end{array}$ & $\begin{array}{l}\text { Hearth/Burned Rock } \\
\text { Midden }\end{array}$ \\
\hline 41KM150 & Burned Rock Midden & Terrace & Middle Archaic & Langtry & $\begin{array}{l}\text { Bedrock Mortar and } \\
\text { Burned Rock Midden }\end{array}$ \\
\hline 41KM18 & Burned Rock Midden & Terrace & Not Reported & Dart Points & $\begin{array}{c}\text { Bruned Rock Middens/ } \\
\text { Hearths }\end{array}$ \\
\hline 41KM21 & Burned Rock Midden & Terrace & Not Reported & $\begin{array}{c}\text { Dart Points and Dawes } \\
\text { Redware }\end{array}$ & $\begin{array}{l}\text { Burned Rock Midden } \\
\text { and Scattered Hearths }\end{array}$ \\
\hline 41KM125 & Burned Rock Midden & Terrace & Possible Middle Archaic & $\begin{array}{l}\text { Dart Point Type Not Re- } \\
\text { ported }\end{array}$ & Burned Rock Midden \\
\hline 41KM162 & Burned Rock Midden & Terrace & Unknown & None & $\begin{array}{l}\text { Burned Rock Midden } \\
\text { and Mortar Holes }\end{array}$ \\
\hline 41KM209 & Burned Rock Midden & Terrace & Unknown & None & $\begin{array}{l}\text { Burned Rock Midden } \\
\text { and Hearth }\end{array}$ \\
\hline $41 \mathrm{KM} 53$ & Burned Rock Midden & Terrace & Unknown & None & Burned Rock Midden \\
\hline 41KM8 & Burned Rock Midden & Terrace & Unknown & Travis-like dart points & $\begin{array}{l}\text { Burned Rock Midden/ } \\
\text { Large Mortar }\end{array}$ \\
\hline 41MS52 & Burned Rock Midden & Terrace & Unknown & None & Burned Rock Midden \\
\hline $41 \mathrm{MS} 32$ & Burned Rock Midden & Terrace & Unknown & None & $\begin{array}{l}\text { Burned Rock Midden/ } \\
\text { Possible Hearth }\end{array}$ \\
\hline $41 \mathrm{MS} 53$ & Burned Rock Midden & Terrace & Unknown & None & Burned Rock Midden \\
\hline $41 \mathrm{KM} 225$ & Burned Rock Midden & Terrace & Unknown & None & Burned Rock Midden \\
\hline 41KM168 & Burned Rock Midden & Terrace & Unknown & Perdiz & Burned Rock Midden \\
\hline 41KM85 & Burned Rock Midden & Terrace & Early-Middle Archaic & $\begin{array}{c}\text { Projectile Points Types Not } \\
\text { Reported }\end{array}$ & Burned Rock Midden \\
\hline $41 \mathrm{KM} 116$ & Isolate & Terrace & Unknown & Retouched Projectile Point & None \\
\hline $41 \mathrm{KM} 46$ & $\begin{array}{c}\text { Lithic Procurement/Pro- } \\
\text { duction }\end{array}$ & Terrace & Unknown & None & None \\
\hline $41 \mathrm{KM} 47$ & \begin{tabular}{|c|}
$\begin{array}{c}\text { Lithic Procurement/Pro- } \\
\text { duction }\end{array}$ \\
\end{tabular} & $\begin{array}{l}\text { Terrace/Hill- } \\
\text { slope }\end{array}$ & Unknown & None & None \\
\hline $41 \mathrm{KM} 59$ & $\begin{array}{c}\text { Lithic Procurement/Pro- } \\
\text { duction }\end{array}$ & Terrace & Unknown & Not Reported & Not Reported \\
\hline $41 \mathrm{KM} 120$ & $\begin{array}{c}\text { Lithic Procurement/Pro- } \\
\text { duction }\end{array}$ & Terrace & Unknown & None & None \\
\hline $41 \mathrm{KM} 50$ & $\begin{array}{c}\text { Lithic Procurement/Pro- } \\
\text { duction }\end{array}$ & Terrace & Unknown & None & None \\
\hline 41KM155 & $\begin{array}{l}\text { Lithic Procurement/Pro- } \\
\text { duction }\end{array}$ & Terrace & Unknown & None & Lithic Workshop \\
\hline
\end{tabular}




\section{7-12 Chapter 7}

Table 7.4. Previously Recorded Archaeological Sites on Terraces, continued

\begin{tabular}{|c|c|c|c|c|c|}
\hline Site & Site Type & Landform & $\begin{array}{c}\text { Archaeological } \\
\text { Periods }\end{array}$ & Diagnostic Tools & Features \\
\hline 41KR233 & $\begin{array}{l}\text { Lithic Procurement/Pro- } \\
\text { duction }\end{array}$ & Terrace & Unknown & $\begin{array}{c}1 \text { Projectile Point Type Not } \\
\text { Reported }\end{array}$ & None \\
\hline 41KR235 & $\begin{array}{c}\text { Lithic Procurement/Pro- } \\
\text { duction }\end{array}$ & Terrace & Unknown & None & None \\
\hline 41KR236 & $\begin{array}{c}\text { Lithic Procurement/Pro- } \\
\text { duction }\end{array}$ & Terrace & Unknown & None & None \\
\hline 41KR237 & $\begin{array}{c}\text { Lithic Procurement/Pro- } \\
\text { duction }\end{array}$ & Terrace & Unknown & None & None \\
\hline $41 \mathrm{KM} 97$ & $\begin{array}{c}\text { Lithic Procurement/Pro- } \\
\text { duction }\end{array}$ & Terrace & Unknown & None & None \\
\hline $41 \mathrm{KM} 82$ & $\begin{array}{c}\text { Lithic Procurement/Pro- } \\
\text { duction }\end{array}$ & Terrace & Unknown & $\begin{array}{l}\text { Dart Point Type Not Re- } \\
\text { ported }\end{array}$ & None \\
\hline $41 \mathrm{KM} 157$ & $\begin{array}{l}\text { Lithic Procurement/Pro- } \\
\text { duction }\end{array}$ & Terrace & Unknown & $\begin{array}{l}\text { Possible Unfluted Paleo } \\
\text { Point }\end{array}$ & Lithic Workshop \\
\hline 41KM15 & Lithic Scatter & Terrace & Late Archaic & Probable Shumla & None \\
\hline $41 \mathrm{MS} 26$ & Lithic Scatter & Terrace & Not Reported & Not Reported & None \\
\hline $41 \mathrm{KM} 22$ & Lithic Scatter & Terrace & Not Reported & $\begin{array}{c}\text { Projectile Points Types Not } \\
\text { Reported }\end{array}$ & Scattered Burned Rock \\
\hline $41 \mathrm{KM} 26$ & Lithic Scatter & Terrace & Not Reported & None & None \\
\hline $41 \mathrm{KM} 28$ & Lithic Scatter & Terrace & Not Reported & Perdiz & Not Reported \\
\hline $41 \mathrm{KM} 89$ & Lithic Scatter & Terrace & Unknown & $\begin{array}{c}\text { Point Fragment Type Not } \\
\text { Reported }\end{array}$ & None \\
\hline 41KM77 & Lithic Scatter & Terrace & Unknown & None & None \\
\hline 41KM96 & Lithic Scatter & Terrace & Unknown & None & None \\
\hline 41KM117 & Lithic Scatter & Terrace & Unknown & None & None \\
\hline 41SU50 & Lithic Scatter & Terrace & Unknown & $\begin{array}{l}2 \text { Dart Points Types Not } \\
\text { Reported }\end{array}$ & None \\
\hline 41KM95 & Lithic Scatter & Terrace & Unknown & None & None \\
\hline 41KR230 & Lithic Scatter & Terrace & Unknown & None & None \\
\hline $41 \mathrm{KM} 83$ & Lithic Scatter & Terrace & Unknown & $\begin{array}{c}\text { Point Fragment Type Not } \\
\text { Reported }\end{array}$ & None \\
\hline 41KM99 & Lithic Scatter & Terrace & Unknown & None & None \\
\hline 41KM98 & Lithic Scatter & Terrace & Unknown & None & None \\
\hline 41SU53 & Lithic Scatter & Terrace & Unknown & None & None \\
\hline $41 \mathrm{KM} 32$ & Lithic Scatter & Terrace & Unknown & None & None \\
\hline $41 \mathrm{MS} 24$ & Lithic Scatter & Terrace & Unknown & None & None \\
\hline $41 \mathrm{KM} 81$ & Lithic Scatter & Terrace & Not Reported & $\begin{array}{c}\text { Distal Projectile Point Frag- } \\
\text { ment }\end{array}$ & None \\
\hline $41 \mathrm{KM} 144$ & Mortar Hole Area & Terrace & Early-Middle Archaic & $\begin{array}{l}\text { Dart Points Types Not } \\
\text { Reported }\end{array}$ & Mortar Holes \\
\hline $41 \mathrm{KM} 149$ & Mortar Hole Area & Terrace & Unknown & None & $\begin{array}{c}\text { Mortar Holes and Grind- } \\
\text { ing Bowl }\end{array}$ \\
\hline 41MS59 & Not Reported & Terrace & Not Reported & Not Reported & Not Reported \\
\hline $41 \mathrm{MS} 60$ & Not Reported & Terrace & Not Reported & Not Reported & Not Reported \\
\hline $41 \mathrm{MS} 61$ & Not Reported & Terrace & Not Reported & Not Reported & Not Reported \\
\hline 41MS62 & Not Reported & Terrace & Not Reported & Not Reported & Not Reported \\
\hline $41 \mathrm{MS} 57$ & Not Reported & Terrace & Not Reported & Not Reported & Not Reported \\
\hline $41 \mathrm{MS} 43$ & Not Reported & Terrace & Not Reported & Not Reported & Not Reported \\
\hline
\end{tabular}


Table 7.4. Previously Recorded Archaeological Sites on Terraces, continued

\begin{tabular}{|c|c|c|c|c|c|}
\hline Site & Site Type & Landform & $\begin{array}{c}\text { Archaeological } \\
\text { Periods }\end{array}$ & Diagnostic Tools & Features \\
\hline $41 \mathrm{MS} 37$ & Not Reported & Terrace & Not Reported & Not Reported & Not Reported \\
\hline $41 \mathrm{MS} 38$ & Not Reported & Terrace & Not Reported & Not Reported & Not Reported \\
\hline $41 \mathrm{MS} 47$ & Not Reported & Terrace & Not Reported & Not Reported & Not Reported \\
\hline $41 \mathrm{MS} 48$ & Not Reported & Terrace & Not Reported & Not Reported & Not Reported \\
\hline 41MS39 & Not Reported & Terrace & Not Reported & Not Reported & Not Reported \\
\hline 41ED105 & Not Reported & Terrace & Not Reported & Not Reported & Not Reported \\
\hline 41KM79 & Not Reported & Terrace & Not Reported & Not Reported & Not Reported \\
\hline $41 \mathrm{KM} 80$ & Not Reported & Terrace & Not Reported & Not Reported & Not Reported \\
\hline $41 \mathrm{KM} 204$ & Not Reported & Terrace & Not Reported & Not Reported & Not Reported \\
\hline 41KM199 & Not Reported & Terrace & Note Reported & Not Reported & Not Reported \\
\hline $41 \mathrm{KM} 200$ & Not Reported & Terrace & Note Reported & Not Reported & Not Reported \\
\hline $41 \mathrm{KM} 62$ & Not Reported & Terrace & Possibly Archaic & $\begin{array}{l}\text { Dart Point Type Not Re- } \\
\text { ported }\end{array}$ & Not Reported \\
\hline $41 \mathrm{KM} 14$ & Open Campsite & Terrace & Unknown & None & Possible Ring Midden \\
\hline $41 \mathrm{KM} 84$ & Open Campsite & Terrace & Late Archaic & $\begin{array}{c}\text { Projectile Points Types Not } \\
\text { Reported }\end{array}$ & None \\
\hline $41 \mathrm{KM} 123$ & Open Campsite & Terrace & Archaic & $\begin{array}{c}\text { Bell, Kinney, Pedernales, } \\
\text { Castroville, Fresno, and } \\
\text { Harahay Knives }\end{array}$ & $\begin{array}{l}\text { Bedrock Mortar Holes, } \\
\text { Possible Buried Burn } \\
\text { Rock Midden, and } \\
\text { Hearth }\end{array}$ \\
\hline $41 \mathrm{KM} 56$ & Open Campsite & Terrace & Archaic & $\begin{array}{c}\text { Pedernales, Bulverde, and } \\
\text { Montell }\end{array}$ & Not Reported \\
\hline $41 \mathrm{KM} 16$ & Open Campsite & Terrace & Archaic/Late Prehistoric & Montell and Perdiz & Not Reported \\
\hline 41KM224 & Open Campsite & Terrace & Early Archaic & Gower & Hearth \\
\hline 41KM115 & Open Campsite & Terrace & $\begin{array}{c}\text { Late and/or Trans. Archaic, } \\
\text { Late Prehistoric }\end{array}$ & Frio, Scallorn-like & Hearths \\
\hline $41 \mathrm{MS} 49$ & Open Campsite & Terrace & Late Archaic & Ensor & None \\
\hline $41 \mathrm{KM} 31$ & Open Campsite & Terrace & Late Archaic & None & None \\
\hline $41 \mathrm{KM} 67$ & Open Campsite & Terrace & $\begin{array}{l}\text { Late Archaic or Late Pre- } \\
\text { historic }\end{array}$ & None & Burned Rock Present \\
\hline 41KM3 & Open Campsite & Terrace & Late Paleo-Late Archaic & Not Reported & Not Reported \\
\hline $41 \mathrm{KM} 226$ & Open Campsite & Terrace & $\begin{array}{c}\text { Late Prehistoric/Neo- } \\
\text { American(Possible Earlier) }\end{array}$ & None & Burned Rock Feature \\
\hline 41MS12 & Open Campsite & Terrace & Not Reported & Not Reported & Not Reported \\
\hline 41KM4 & Open Campsite & Terrace & Not Reported & Not Reported & Not Reported \\
\hline $41 \mathrm{KM} 12$ & Open Campsite & Terrace & Not Reported & Not Reported & Hearths \\
\hline $41 \mathrm{KM} 20$ & Open Campsite & Terrace & Not Reported & Not Reported & Scattered Hearth \\
\hline $41 \mathrm{KM} 23$ & Open Campsite & Terrace & Not Reported & $\begin{array}{c}\text { Projectile Points Types Not } \\
\text { Reported }\end{array}$ & $\begin{array}{c}\text { Burned Rock Accumula- } \\
\text { tion }\end{array}$ \\
\hline $41 \mathrm{KM} 25$ & Open Campsite & Terrace & Not Reported & $\begin{array}{c}\text { Projectile Point Fragments } \\
\text { Types Not Reported }\end{array}$ & $\begin{array}{c}\text { Burned Rock Accumula- } \\
\text { tion }\end{array}$ \\
\hline $41 \mathrm{KM} 34$ & Open Campsite & Terrace & Possible Late Archaic & None & $\begin{array}{c}\text { Burned Rock Concentra- } \\
\text { tion }\end{array}$ \\
\hline $41 \mathrm{KM} 166$ & Open Campsite & Terrace & Unknown & Not Reported & Hearth and FCR Scatters \\
\hline $41 \mathrm{MS} 31$ & Open Campsite & Terrace & Unknown & None & None \\
\hline $41 \mathrm{KM} 129$ & Open Campsite & Terrace & Unknown & None & Possible Hearth \\
\hline
\end{tabular}




\section{7-14 Chapter 7}

Table 7.4. Previously Recorded Archaeological Sites on Terraces, continued

\begin{tabular}{|c|c|c|c|c|c|}
\hline Site & Site Type & Landform & $\begin{array}{c}\text { Archaeological } \\
\text { Periods }\end{array}$ & Diagnostic Tools & Features \\
\hline 41KM94 & Open Campsite & Terrace & Unknown & None & $\begin{array}{l}\text { Possible Hearth Rem- } \\
\text { nants }\end{array}$ \\
\hline 41KM156 & Open Campsite & Terrace & Unknown & None & Hearths \\
\hline 41KM206 & Open Campsite & Terrace & Unknown & None & Burned Rock Scatter \\
\hline 41KM203 & Open Campsite & Terrace & Unknown & None & $\begin{array}{l}\text { Possible Burned Rock } \\
\text { Midden and Hearths }\end{array}$ \\
\hline 41KM92 & Open Campsite & Terrace & Unknown & None & None \\
\hline 41KM93 & Open Campsite & Terrace & Unknown & None & Burned Rock Present \\
\hline 41KM169 & Open Campsite & Terrace & Unknown & None & Hearth \\
\hline $41 \mathrm{KM} 33$ & Open Campsite & Terrace & Unknown & None & $\begin{array}{c}\text { Burned Rock Concentra- } \\
\text { tion }\end{array}$ \\
\hline $41 \mathrm{KM} 27$ & Open Campsite & Terrace & Unknown & None & Hearths \\
\hline $41 \mathrm{KM} 91$ & Open Campsite & Terrace & Unknown & Possible Plainview & Hearth \\
\hline $41 \mathrm{KM} 29$ & Open campsite & Terrace & Unknown & Pedernales & Hearth \\
\hline $41 \mathrm{KM} 126$ & Open campsite & Terrace & Unknown & $\begin{array}{l}\text { Uvalde-like, Ensor, Triangu- } \\
\text { lar }\end{array}$ & Hearths \\
\hline 41KM90 & Open Campsite & Terrace & Unknown & None & Hearth \\
\hline 41KM184 & Open Campsite & Terrace & Unknown & None & None \\
\hline $41 \mathrm{KM} 78$ & $\begin{array}{l}\text { Open Campsite/Lithic } \\
\text { Procurement }\end{array}$ & Terrace & Late Archaic & $\begin{array}{l}\text { Dart Points Types Not } \\
\text { Reported }\end{array}$ & None \\
\hline $41 \mathrm{KR} 475$ & $\begin{array}{c}\text { Open Campsite/Lithic } \\
\text { Procurement }\end{array}$ & Terrace & Unknown & None & None \\
\hline $41 \mathrm{KM} 167$ & $\begin{array}{l}\text { Open Campsite/Lithic } \\
\text { Procurement }\end{array}$ & Terrace & Unknown & None & Scattered Burned Rock \\
\hline $41 \mathrm{KM} 6$ & $\begin{array}{l}\text { Open Campsite/Lithic } \\
\text { Procurement }\end{array}$ & Terrace & Unknown & Clifton, 14 arrowpoints & Burned Rock Midden \\
\hline $41 \mathrm{KM} 211$ & $\begin{array}{l}\text { Open Camsite/Burned } \\
\text { Rock Midden/Quarry }\end{array}$ & Terrace & Unknown & None & $\begin{array}{c}\text { Burned Rock Midden/ } \\
\text { Quarry }\end{array}$ \\
\hline $41 \mathrm{KM} 212$ & $\begin{array}{l}\text { Lithic Procurement/ } \\
\text { Burned Rock Midden }\end{array}$ & Terrace & Unknown & None & Burned Rock Midden \\
\hline 41KM151 & $\begin{array}{l}\text { Lithic Procurment/ } \\
\text { Burned Rock Midden }\end{array}$ & Terrace & Middle Archaic & Pedernales & $\begin{array}{l}\text { Bedrock Mortar, Burned } \\
\text { Rock Midden, Hearth, } \\
\text { and Shell Concentration }\end{array}$ \\
\hline $41 \mathrm{KM} 9$ & $\begin{array}{l}\text { Lithic Procurement/ } \\
\text { Burned Rock Midden }\end{array}$ & Terrace & Unknown & Not Reported & $\begin{array}{c}\text { Lithic Workshop/ Burned } \\
\text { Rock Middens }\end{array}$ \\
\hline $41 \mathrm{MS} 55$ & \begin{tabular}{|c|} 
Lithic Scatter/Workshop/ \\
Burned Rock Midden
\end{tabular} & Terrace & Unknown & None & Burned Rock Midden \\
\hline 41KM154 & $\begin{array}{l}\text { Lithic Procurement/ } \\
\text { Burned Rock Midden }\end{array}$ & Terrace & Late Archaic & Edgewood & $\begin{array}{l}\text { Burned Rock Middens, } \\
\text { Hearth, and Mortar Holes }\end{array}$ \\
\hline $41 \mathrm{MS} 23$ & Rock Shelter & Terrace & Late Prehistoric & 5 Perdiz & Mortar Holes \\
\hline 41KM147 & Rock Shelter & Terrace & Unknown & None & None \\
\hline $41 \mathrm{KM} 2$ & $\begin{array}{l}\text { Rockshelter/Burned } \\
\text { Rock Midden }\end{array}$ & Terrace & Not Reported & Not Reported & $\begin{array}{l}\text { Burned Rock Midden } \\
\text { and Petroglyph }\end{array}$ \\
\hline $41 \mathrm{KM} 2$ & $\begin{array}{l}\text { Rockshelter/Burned } \\
\text { Rock Midden }\end{array}$ & Terrace & Not Reported & Not Reported & $\begin{array}{l}\text { Burned Rock Midden } \\
\text { and Petroglph }\end{array}$ \\
\hline $41 \mathrm{KM} 1$ & \begin{tabular}{|c|} 
Rockshelter/Open \\
Campsite/Burned Rock \\
Midden
\end{tabular} & Terrace & Not Reported & Not Reported & $\begin{array}{c}\text { Rockshelter and Burned } \\
\text { Rock Midden }\end{array}$ \\
\hline
\end{tabular}


Table 7.5. Previously Recorded Archaeological Sites on Upland Drainages

\begin{tabular}{|c|c|c|c|c|c|}
\hline Site & Site Type & Landform & $\begin{array}{c}\text { Archaeological } \\
\text { Periods }\end{array}$ & Diagnostic Tools & Features \\
\hline 41ED8 & Burned Rock Midden & Upland Drainage & Not Reported & Not Reported & Burned Rock Midden \\
\hline 41SU17 & Burned Rock Midden & Upland Drainage & Unknown & Not Reported & Burned Rock Midden \\
\hline 41SU5 & Burned Rock Midden & Upland Drainage & Unknown & Not Reported & Burned Rock Midden \\
\hline 41SU6 & Burned Rock Midden & Upland Drainage & Unknown & Not Reported & Burned Rock Midden \\
\hline 41SU18 & Burned Rock Midden & Upland Drainage & Not Reported & Dart Points & Burned Rock Midden \\
\hline 41ED111 & Burned Rock Midden & Upland Drainage & Not Reported & Not Reported & Burned Rock Midden \\
\hline 41SU51 & Lithic Scatter & Upland Drainage & Unknown & None & None \\
\hline 41KM37 & Open Campsite & Upland Drainage & Unknown & None & None \\
\hline
\end{tabular}

However, with the projectile points recovered from the site, the researchers determined the site was occupied most heavily during the Round Rock, San Marcos, and Twin Sisters phases.

\section{SITE 41KM62}

Site 41KM62 is located opposite 41KM61 on the eastern bank of the James River, also about 12 miles east-southeast of 41KM225. It sits on a large terrace over the James River, within an oat field and winter pasture of the same pioneer homestead as 41KM61 (Young 1986). It covers about 20 acres of the wedge-shaped terrace, and three burned rock middens could be seen on the surface. A possible lithic procurement area was also located on a ridge immediately east of the field. The same transportation project that would impact site 41KM61 would also impact 41KM62, and SDHPT tested both sites at the same time. All of the features were located outside of the proposed ROW, and none were investigated further with the exception of a surface collection in and around the features. The soil typology was rather different than that at $41 \mathrm{KM} 61$, with black clay loam over caliche deposits; no bedrock was observed above 80 $\mathrm{cmbs}$. Historic and prehistoric material was seen in the $20-\mathrm{cm}$ plow zone, but no discrete cultural components were seen in the more intact zones within the excavation units.

As with 41KM61, most of the site interpretation was conducted using the available data from the surface artifacts, also from the Archaic period (particularly the Clear Fork, Round Rock, San Marcos, and Twin Sisters phases) into the Neo-American period. The same chronology used for the analysis of 41KM61 was also used for 41KM62 (Table 7.8). No radiocarbon dates were established at the site, but the diagnostic projectile points include Pedernales, Frio-like, Castroville, Nolan, Pedernales-like, and Marshall- or Castroville-like, and arrow point fragments. Leon Plain ceramics were also found near the arrow points. Larger quantities of domestic artifacts such as manos, metates, and scrapers indicate this area was once a village site, or at least an area of longer occupation. Researchers concluded that the tested areas did not retain sufficient integrity to merit inclusion to the NRHP or listing as an SAL, but highly suspected that more important information to the understanding of prehistory may be located in other areas of the site. 





Table 7.7. Chronology Used by Researchers of the Red Creek Site (41KM3)

\begin{tabular}{|c|c|c|c|c|}
\hline Period & Phase & B.c./A.D. Dates & B.P. Dates & Associated Projectile Points \\
\hline Paleoindian & n/a & $10,000-6500$ B.c. & $11,950-8,450$ & Clovis, Folsom, Plainview \\
\hline $\begin{array}{c}\text { Late Paleoindian/ } \\
\text { Early Archaic }\end{array}$ & n/a & $6500-5000$ B.c. & $8,450-6,950$ & Angostura, Gower \\
\hline \multirow{5}{*}{ Archaic } & San Geronimo & $5000-3000$ B.c. & $6,950-4,950$ & Bell, Uvalde, Martindale, "Early Barbed" \\
\cline { 2 - 5 } & Clear Fork & $3000-2000$ B.c. & $4,950-3,950$ & Tortugas, Travis, Nolan, Bulverde, La Jita \\
\cline { 2 - 5 } & Round Rock & $2000-500$ B.c. & $3,950-2,450$ & Pedernales, Langtry, Val Verde \\
\cline { 2 - 5 } & San Marcos & 500 B.C.-A.D. 150 & $2,450-1,800$ & Lange, Castroville, Montell, Marshall, \\
& Twin Sisters & A.D. $150-1250$ & $1,800-700$ & Ensor, Frio, Darl \\
\cline { 2 - 5 } & & & & \\
\hline
\end{tabular}

Table 7.8. Chronology Used by Researchers of 41KM61 and 41KM62

\begin{tabular}{|c|c|c|c|c|}
\hline Period & Phase & B.c./A.D. Dates & B.P. Dates & Associated Projectile Points \\
\hline Paleoindian & n/a & ???-7000 B.c. & $? ? ?-8950$ & Fluted and lanceolate \\
\hline \multirow{4}{*}{ Archaic } & San Geronimo & $7000-3000$ B.c. & $8,950-4,950$ & Bell, Gower, Uvalde, "Early Barbed" \\
\cline { 2 - 5 } & Clear Fork & $3000-2000$ B.c. & $4,950-3,950$ & Travis, Nolan, Pandale \\
\cline { 2 - 5 } & Round Rock & $2000-1000$ B.c. & $3,950-2,950$ & Pedernales, Langtry, Val Verde \\
\cline { 2 - 5 } & San Marcos & 1000 B.C.-A.D. 100 & $2,950-1,850$ & Frio, Ensor, Montell, Marcos, Castroville \\
\cline { 2 - 5 } & Twin Sisters & A.D. $100-1350$ & $1,850-600$ & Ensor, Frio, Darl \\
\hline \multirow{2}{*}{ Neo-American } & Austin & No date listed & No date listed & Scallorn \\
\cline { 2 - 5 } & Toyah & No date listed & No date listed & Perdiz \\
\hline
\end{tabular}

\section{SITE $41 K M 90$}

Discovered in 1987, site 41KM90 is located on a colluvial terrace above the South Llano River on the south side within the boundaries of South Llano River State Park managed by the Texas Parks and Wildlife Department (TPWD) (Robinson 1994:23). It is about 7.3 miles away from $41 \mathrm{KM} 225$, almost due west. A small drainage is situated just east of the site, and empties into the South Llano River about $600 \mathrm{~m}$ to the north. The site is located on the lower part of the terrace slopes, between the sharp rise in elevation to hilltops and the floodplain of the South Llano River. It is possible that the site was sealed by alluvial deposition early in its history. The site is approximately 6 acres $(270 \mathrm{~m}$ long by $90 \mathrm{~m}$ wide) and contains both surface and subsurface artifacts. One feature was found on the surface, and another in the wall of an excavated utility trench. Prehistoric artifacts and lithic debris were seen scattered on the surface of the 6 acre site. The site was partially excavated in 1989 to test its significance and determine what impacts proposed improvements to the park would have on the site, and monitoring was conducted while the improvements were underway. As with above mentioned transportation projects, only those areas that would be impacted by construction were investigated. Thus, researchers could not make a determination of the overall site's eligibility for inclusion in the NRHP, but they did indicate the site would qualify as an SAL since it is located on public property (Robinson 1994:58).

The surface feature consisted of an oval shaped burned rock hearth, with a single layer of burned limestone cobbles, mussel shell, and charcoal. 
The subsurface feature, seen $20 \mathrm{cmbs}$ in a trench wall, contained burned limestone, debitage, and ashy soil in a shallow basin shape. Researchers remarked that each hearth looked different, and perhaps were used for different purposes (Robinson 1994:25). No diagnostic artifacts were found with either feature, and the charcoal was too small to gather for radiocarbon assays. Likewise, no diagnostic artifacts were found anywhere on the site surface or areas that were excavated. Site 41KM90 was determined to be a seasonal domestic campsite of unknown age, but with evidence of at least two different types of cooking activities present.

\section{SITE $41 K M 115$}

Site $41 \mathrm{KM} 115$ is located only about $700 \mathrm{~m}$ west from $41 \mathrm{KM} 90$, at a very similar elevation on the same terrace above the South Llano River on the south side (Robinson 1994:26). It was initially recorded in early 1989 , and as it was also to be impacted by the development of park facilities, limited testing was conducted at the site later that year. The tested area surrounded the proposed location of a park road within the site. Slightly larger than $41 \mathrm{KM} 90$, site $41 \mathrm{KM} 115$ covers about 8 acres (approximately 260-X-130 $\mathrm{m}$ in size), and many features were observed under a cover of alluvium between 10 and $30 \mathrm{cmbs}$. Very few artifacts were seen on the surface. Four features were observed in the excavation units, including a limestone slab hearth laid in a shallow basin about $30 \mathrm{cmbs}$, a scatter of seven large burned rocks that might have been a destroyed hearth about $30 \mathrm{cmbs}$, a burned limestone slab-lined hearth located stratigraphically higher than the other hearths $(15-20 \mathrm{cmbs})$, and a disbursed limestone cobble hearth at $30 \mathrm{cmbs}$ with a mammal mandible tucked under one of the rocks. No charcoal stains or burned soil patterns were observed in any of the features, but a Frio dart point was located under the stones in one feature and bone fragments were found in all of the features (Robinson 1994). The range of features and diagnostic artifacts indicates a Late Archaic to early Late Prehistoric period serial occupation of the site area, most likely a medium-to long-term campsite where a wide variety of activities took place.

Unfortunately, the cultural chronology used by the investigators was not specifically defined in the report. However, a chronological sequence can be derived from their use of Turner and Hester (1993) to identify the projectile points recovered from the site. Turner and Hester (1993) generalize the archaeological sequences for the whole state into Paleoindian (9200-6000 B.c.), Early Archaic (6000-2500 B.c.), Middle Archaic (2500-1000 B.c.), Late Archaic (1000-300 B.c.), Transitional Archaic (300 B.C. to A.D. 700), and Late Prehistoric (A.D. 700 to historic times). This may be the sequence the authors used to associate the Frio dart points, the untyped triangular dart points, and the Scallorn points to the Late Archaic and early Late Prehistoric periods. Prewitt (1981), in his central Texas projectile point sequence, associates the Frio point type to the Uvalde and Twin Sisters phases of the Late Archaic, and the Scallorn point type to the Austin Phase of the Neo-Archaic (Late Prehistoric). His table is reprinted in Turner and Hester (1993:52).

NRHP determinations were not made due to the limited testing, but the author suggests the site qualifies for SAL status as it is located on publicly owned property (Robinson 1994:58).

\section{SITE $41 K M 126$}

Site 41KM126 was located during some subsurface excavation work at the South Llano River State Park in 1989, but it was not given a site trinomial until testing began in 1990 (Robinson 1994:37). At the time there was no surface evidence of the site's existence. The site is located about $1.3 \mathrm{~km}$ west of $41 \mathrm{KM} 90$ and about 600 $\mathrm{m}$ west of $41 \mathrm{KM} 115$ on the outside of a bend in 
the South Llano River, on the same wide terrace as the other two sites. It is at about the same elevation as well. The site was to be impacted by the development of park facilities, and limited testing was conducted in those areas. A meander scar nearby the site indicates the current course of the river was not its course in antiquity, and several flooding events have likely impacted the site either by depositing silt over the occupation surfaces or scouring away at them leaving little deposition (Robinson 1994:37). Post depositional changes are indicated by the low quantity of recovered artifacts compared to the number of features. The site covers about 26 acres (approximately $420-\mathrm{x}-250 \mathrm{~m}$ in size), and contains eight features. Feature $1 / 2$ is the remains of a hearth with an upper layer of stone at $30 \mathrm{cmbs}$ uncovered in a disturbed context in Test Pit 2, but the lower burned rock at $50 \mathrm{cmbs}$ was largely intact. It was first observed as two clusters of rock (labeled Features 1 and 2) that merged into one. Below Feature 1/2, at $110 \mathrm{cmbs}$ in Test Pit 2 , Feature 5 was observed to be a small hearth with an intact layer surrounded by disbursed loose burned rocks. Feature 3 is an oval-shaped slab lined hearth with a flat slab bottom and cobbles radiating out at a slight angle, creating a basin-shape at about $30 \mathrm{cmbs}$ in Test Pit 3. An Ensor point was found with the hearth. Below this feature in Test Pit 3, Feature 7 is the remains of a slab-lined, oval-shaped hearth with a basin shape created by limestone slabs. It is very similar in shape and form to Feature 3 , about $20-30 \mathrm{~cm}$ above it in profile. A burned rock scatter, possibly the remains of a hearth, was located at $40 \mathrm{cmbs}$ in Test Pit 4 (Feature 4), a scatter of burned rock, large quantities of debitage, and five chert cores between 24-29 cmbs were located in Test Pit 5 (Feature 6), and a hearth remnant destroyed by a backhoe trench (Feature 8) were also found and recorded.

Site 41KM126 was interpreted as a long-term multi-occupation campsite or village where several varieties of cooking techniques were employed and the local gravels were exploited for their chert cobbles (Robinson 1994:45). The site was not investigated in sufficient depth to make a NRHP determination, but the author does indicate the site qualifies as a SAL since it is located on public property (Robinson 1994:58). Charcoal was observed in and around several of these hearths, but no samples were sent for radiocarbon assays. However, the limited testing did determine multiple occupations separated between layers of alluvial sediments, with at least one direct association between a feature and a diagnostic projectile point (Feature 3 ). The Ensor point suggests a Late Archaic (1000-300 B.C.) occupation, which would imply that Feature 7, located below Feature 3, is a much earlier cooking feature. Other than the Ensor, a Uvalde dart point and an untyped triangular point was found in a backhoe trench. Using the archaeological sequences from Turner and Hester (1993) the Uvalde point is a later Early Archaic (6000-2500 B.c.) point type. Prewitt (1981) names it the Jarrell Phase of the Early Archaic, and he categorizes the Ensor point as a Twin Sisters Phase Late Archaic type.

\section{Honey CREek Site (41MS32)}

Recorded in October 1987, site 41MS32 is located on a high terrace-bench overlooking Honey Creek on the north side (SDHPT 1987). It is about 27.5 miles northeast of $41 \mathrm{KM} 225$. The site extends from the edge of the terrace upslope at least $50 \mathrm{~m}$. Several impacts to the site were observed when it was found, including the construction of a county road on the northwest side of the site, a goat shed, concrete wall, fence line, and live oak trees within the observed burned rock midden, and erosion from plowing and fence lines throughout the rest of the site area. The site is approximately 0.6 acres $(50-\mathrm{x}-50 \mathrm{~m}$ in size), and some cultural material, including a $15-\mathrm{x}-20 \mathrm{~m}$ burned rock midden, was visible on the surface. The site is located in an area that was going to be impacted by the development 
of FM 1871 just at the point where it crosses Honey Creek. The proposed roadway and bridge was going to significantly disturb the site. It was investigated with limited test excavations only a month after it was first recorded, November 3-12, 1987, by SDHPT. The investigations were designed to determine the site extent and depth of deposits, as well as some indication of the age of the cultural material (SDHPT 1987:18). No determinations as to the site's eligibility for inclusion to the NRHP or for listing as an SAL were made, but a research design for further mitigation investigations was included in the report. Data recovery excavations were carried out from November 23, 1987 through April 1988 (Black et al. 1997:104).

During testing, researchers investigated the majority of the known site area, as it was going to be almost completely destroyed by the proposed roadway. Although the report indicated the existence of several prehistoric features at the site, the only one described is the burned rock midden (SDHPT 1987:22). The midden at 41MS32 is similar to Late Prehistoric middens, relatively small, with a slight depression that could be a possible oven area, dark ashy soil, with an arrow point (no indication of which one), debitage, and manos found nearby.
As no charcoal samples were submitted for radiocarbon assay during site testing, only the presence of diagnostic tools indicated the temporal associations for the observed cultural material. The authors primarily used the cultural chronology developed by Weir (1976) and Prewitt (1981). Table 7.9 presents a summary of the chronology used in 1987. Based on the chronology in Table 7.9, the site's diagnostic material (including a Bell-Andice, Early Triangular, Travis-like, untyped arrow point, Edwards, and Scallorn- or Edwards-like), pointed to two separate occupation periods: the San Geronimo and Clear Fork phases of the (Early and Middle) Archaic period, and the Austin Phase of the Late Prehistoric period (SDHPT 1987:24-27).

Based on the recovery of Early Archaic to Late Prehistoric diagnostics and the discovery of a burned rock midden, which is typically associated with Late Archaic, TxDOT decided to conduct data recovery investigations at the Honey Creek Site. Data recovery at the site had four major research objectives: 1) establish a cultural chronology for the occupation of the site, 2) identify elements of the subsistence base, 3) identify site activities, and 4) identify locally available lithic resources and the possible sources of non-local lithic resources (Black et al. 1997).

Table 7.9. Chronology Used by Researchers of the Honey Creek Site (41MS32) During Testing

\begin{tabular}{|c|c|c|c|c|}
\hline Period & Phase & B.c./A.D. Dates & B.P. Dates & Associated Projectile Points \\
\hline Paleoindian & $\mathrm{n} / \mathrm{a}$ & $10,000-6500$ B.C. & $11,950-8,450$ & Clovis, Folsom, Plainview \\
\hline $\begin{array}{c}\text { Late Paleoindian/ } \\
\text { Early Archaic }\end{array}$ & $\mathrm{n} / \mathrm{a}$ & No date listed & No date listed & Angostura, Gower \\
\hline \multirow{4}{*}{ Archaic } & San Geronimo & $6500-3000$ B.C. & $8,450-4,950$ & Bell, Uvalde, Martindale, "Early Barbed" \\
\cline { 2 - 5 } & Clear Fork & $3000-2000$ B.C. & $4,950-3,950$ & Tortugas, Travis, Nolan, Bulverde \\
\cline { 2 - 5 } & Round Rock & $2000-500$ B.C. & $3,950-2,450$ & Pedernales, Langtry, Val Verde \\
\cline { 2 - 5 } & San Marcos & 500 B.C.-A.D. 150 & $2,450-1,800$ & $\begin{array}{c}\text { Lange, Castroville, Montell, Marshall, } \\
\text { Marcos }\end{array}$ \\
\cline { 2 - 5 } & Twin Sisters & A.D. 150-700 & $1,800-1,250$ & Ensor, Frio, Darl \\
\hline \multirow{2}{*}{ Late Prehistoric } & Austin & A.D. 700-1200 & $1,250-750$ & Scallorn, Edwards, Granbury \\
\cline { 2 - 5 } & Toyah & A.D. $1200-1750$ & $750-200$ & Perdiz, Cliffton \\
\hline
\end{tabular}


Excavations began in late November 1987, and continued into mid April 1988. A total of 30 features were recorded during the excavations consisting mostly of discrete clusters of burned rocks divided into two categories designated "primary" and "dispersed" features. These features appeared to "stand apart" from the general rocks spread across much of the site (Black et al. 1997:112). In addition, the excavations recovered a total of 104 projectile points, 285 bifaces, 28 unifaces, 176 cores, 32 pieces of groundstone, 64 modified flakes, and 36,311 pieces of debitage.

Based on the amount of diagnostic artifacts recovered from the site, investigations determined general periods of occupation at the site. Based on the artifacts, seven time periods were identified correlating with the artifacts recovered. These consist of: the Early Archaic, the Middle Archaic, the Late Archaic I, the Late Archaic II, the Early Post-Archaic (Austin), the Late PostArchaic to early Historic (Toyah), and the Historic (Ranching) periods. Table 7.10 summarizes the dates and diagnostics recovered attributed to each time period.

Excavations concentrated on investigating the features with special emphasis on the burned rock midden observed during testing. Materials, including samples, recovered from the investi- gations enabled the identification of four units independent of stratigraphy and the time periods outlined by the site's artifact chronology. These were identified as AU 1-4 with AU 1 comprised of materials dating from the late Early Archaic (ca. 3600 B.c.) or earlier, AU 2 comprised of materials spanning the Middle and Late Archaic periods (3600 B.C. to A.D. 800), AU 3 comprised of post-Archaic (Transitional Archaic to Late Prehistoric) and early historic cultural materials (A.D. 800-1750?), and AU 4 being the midden (A.D. 1100-1700) (Black et al. 1997). The site was found to be occupied most heavily during the post-Archaic to early Historic (within AU 3 and AU 4).

In many areas the stratification of the Honey Creek site was gradual. This resulted in rather narrow bands of stratigraphic zones from old near the bedrock and young towards the surface, which did not clearly match the identified time periods above. Radiocarbon dating also proved to complicate matters further rather than clearing things up. Thus, researchers in the end identified, where possible, features to the Late Prehistoric and Archaic periods. Data recovery investigations at the site focused on the feature construction, function, and the determination of cooking or processing techniques. In addition to the feature analysis, an artifact distribution analysis was conducted that produced 10 artifact

Table 7.10. Chronology Used by Researchers of the Honey Creek Site (41MS32) During Data Recovery

\begin{tabular}{|c|c|c|c|}
\hline Period & B.c./A.c. Dates & B.P. Dates & Associated Projectile Points \\
\hline $\begin{array}{c}\text { Early Archaic and Late } \\
\text { Paleoindian }\end{array}$ & Before 3600 B.C. & Before 5,550 & Golondrina, St. Mary's Hall, Martindale, Andice \\
\hline Middle Archaic & $3600-2300$ B.c. & $5,550-4,250$ & Nolan, Early Triangular, Bulverde \\
\hline Late Archaic I & $2300-600$ B.c. & $4,250-2,550$ & Pedernales, Castroville, Montell, Marcos \\
\hline Late Archaic II & 600 B.C.- A.D. 800 & $2,550-1,150$ & Ensor, Frio, Fairland, Darl \\
\hline $\begin{array}{c}\text { Early Post-Archaic (Austin) } \\
\text { A.D. } 800-1350\end{array}$ & $1,150-600$ & Scallron, Edwards \\
\hline $\begin{array}{c}\text { Late Post-Archaic (Toyah) } \\
\text { to early historic }\end{array}$ & A.D. $1350-1750$ & $600-200$ & Perdiz, earthenware pottery \\
\hline Historic Ranching & 1850 to Present & $200-0$ & Metal, glass, concrete, etc. \\
\hline
\end{tabular}


clusters that indicated specific activity areas around the burned rock midden.

\section{THE NEXT WEEK SITE (41SU20)}

The Next Week Site (41SU20) is located on a low hillslope on the north side of an unnamed intermittent tributary of the aptly named Dry Llano in Sutton County, Texas (Doran 1976). It is about 30 miles due west of $41 \mathrm{KM} 225$. The site is defined as a small burned rock midden about 35 feet in diameter, but upon further inspection it was observed that a large quantity of lithic material is located on the opposite side of the creekbed on a mesa slope between the creekbed and IH-10. The researchers were not sure if the lithic debris and the midden were connected, although several cores, flakes, and tools (unifaces, bifaces, and utilized flakes) indicate that area was occupied by prehistoric groups. If the site area was expanded to include this surface lithic scatter, the size would be about 5 acres (450 feet north-south by 500 feet east-west [137.16-x-152.4 m]). The site was found early in 1975 and excavated in March and April 1975 by the SDHPT. FM 3130 passes just north of the burned rock midden and $\mathrm{IH}-10$ crosses the area to the south, and the future expansion of either road would certainly impact the site.

No other features were observed at the site, and only the southern half of the midden was excavated. The midden was observed to be 2.5 feet in the center, and pinched out to the east and west. No natural depression was observed, and the bottom of the midden was found to be flat across a colluvial surface. Mussel shell was seen in the midden, suggesting a more reliable water source than the current environment suggested, and numerous lithic materials were recovered. No definitive diagnostic artifacts were located, but two artifacts classified as bifaces exhibit several characteristics that are similar to a Uvalde projectile point and a Clear Fork gouge. If these tool identifications are correct, the occupation of the site would date to the Early Archaic (Doran 1976:18, 57). Researchers do not cite a specific chronological sequence derived by serial point typology in their report, but instead take the point descriptions developed by others, such as Suhm and Jelks (1962), Hester (1971), and Weir (1975), and connect them to the Early Archaic (with no specified dates). They reference one biface belonging to the San Geronimo and Twin Sisters phases based on personal conversation with Frank Weir (Doran 1976:18).

A comparative site study was conducted between the Next Week Site and 14 other sites across west and north-central Texas, but no discernable patterns in the lithic class frequencies were observed. A comparison to the Stickleaf Site (41ED8) was also made, and many similarities were noted (see also Keller 1976). Similarities included settings on dry creeks, presence of burned rock middens, locations near an abundant lithic resource, and higher ratios of flaking material, cortex flakes and cores external to the midden. Differences included higher degrees of thermal alteration at the Stickleaf Site and a slightly higher incidence of bifaces at the Next Week Site (Doran 1976:55). Combined, the evidence suggests similar activities were conducted at both sites. However, the Stickleaf Site shows a greater emphasis on lithic production, whereas the Next Week Site indicates a greater emphasis on plant processing. The report did not mention site 41SU20's eligibility for inclusion to the NRHP or for listing as an SAL.

\section{THE WeSTEX Folly Site (41SU18)}

Site 41SU18, the Westex Folly Site, is located in an upland drainage on the east bank of a small dry tributary of Live Oak Draw, which connects with Eightmile Draw at Eightmile Waterhole about $5.8 \mathrm{~km}$ to the southeast, which then links up with the Dry Llano that leads to the North Llano River (Luke 1981). It is about 38.2 miles west of 41KM225. The Westex Folly Site is 
nestled in a small valley surrounded by steeper elevations on the east, north, and west sides. The tributary has carved out a depression towards the south. The site is at least 1.8 acres in size (400 feet long by 200 feet wide). Three burned rock middens and lithic material can be seen on the surface, as the soils are very thin and large areas of exposed bedrock are present. Two of these middens were located in the area that was to be impacted by the proposed ROW of IH-10, and both were excavated on April 16-18, 1974 by SDHPT. The goal of the testing excavations was to determine the structure of the two middens.

Since site 41SU18 is located in a transitional area between central Texas and the Trans-Pecos, the authors considered the chronological sequences developed for both areas in their investigation. For the Trans-Pecos, they relied on the excavations of rockshelters at Amistad Reservoir and the chronology developed by Dee Ann Story (Story and Bryant 1966). As for the central Texas region, they utilized Weir (1976) for their chronology, focusing on the Archaic period. The chronology they used is profiled in Table 7.11.
Researchers investigated only those portions of the site within the proposed ROW, but it was clear that the site extended far beyond the investigated area. The first midden investigated, closest to the draw, was found to be about 30 feet in diameter, and rising above the modern ground surface about 1 foot (Luke 1981:7). A central pit was located extending down below the modern ground surface to a depth of 3 feet; it measured 5 feet in width at the top (surface of midden) and reduced in size to 2 feet at the bottom (at bedrock). The pit was located within a crack or natural depression in the bedrock, which allowed the pit of such depth to be formed easily. The matrix of the burned rock midden was found to consist of dark, ashy soil and burned limestone rocks, with the pit containing a much higher percentage of ashy soil than burned rock.

The second feature to be investigated consisted of an oval-shaped burned rock midden about 35-x-20 feet in size, with a central depression (Luke 1981:7). This midden was built on shallow soil and its thickness was only a few inches. The only artifact closest to an identifiable projectile

Table 7.11. Chronology Used by Researchers of the Westex Folly Site (41SU18)

\begin{tabular}{|c|c|c|c|c|}
\hline \multicolumn{2}{|l|}{ Period } & B.C./A.D. Dates & B.P. Dates & Associated Projectile Points \\
\hline \multicolumn{5}{|c|}{ Trans-Pecos } \\
\hline \multicolumn{2}{|l|}{ Period I } & ??? -7000 в.с. & $? ? ?-8,950$ & Plainview, Folsom, Angostura, Lerma \\
\hline \multicolumn{2}{|l|}{ Period II } & $7000-4000$ в.с. & $8,950-5,950$ & Gower, Early Barbed, Uvalde \\
\hline \multicolumn{2}{|c|}{ Period III } & $4000-2500$ в.с. & $5,950-4,450$ & Nolan Pandale \\
\hline \multicolumn{2}{|c|}{ Period IV } & $2500-1000$ в.с. & $4,450-2,950$ & Langtry, Almagre, Val Verde \\
\hline \multicolumn{2}{|l|}{ Period V } & $1000-200$ в.с. & $2,950-2,150$ & Montell, Castroville, Shumla, Marshall, Marcos \\
\hline \multicolumn{2}{|c|}{ Period VI } & 200 B.C.-A.D. 1000 & $2,150-950$ & Ensor, Frio, Paisano, Figueroa \\
\hline \multicolumn{2}{|c|}{ Period VII } & A.D. $1000-1600$ & $950-350$ & Cliffton, Perdiz, Toyah \\
\hline \multicolumn{2}{|c|}{ Period VIII } & A.D. $1600+$ & $350+$ & Metal arrow points, European contact \\
\hline Period & Phase & B.C./A.D. Dates & B.P. Dates & Associated Projectile Points \\
\hline \multicolumn{5}{|c|}{ Central Texas } \\
\hline \multirow{5}{*}{ Archaic } & San Geronimo & $6000-2500$ в.с. & $7,950-4,450$ & Bell, Angostura, Gower, Uvalde, Martindale, "Early Barbed" \\
\hline & Clear Fork & 3000-2000 в.с. & $4,950-3,950$ & Tortugas, Travis, Nolan, Bulverde \\
\hline & Round Rock & $2200-600$ в.с. & $4,150-2,550$ & Pedernales \\
\hline & San Marcos & 800 B.C. - A.D. 200 & $2,750-1,750$ & Lange, Castroville, Montell, Marshall, Marcos \\
\hline & Twin Sisters & A.D. $0-1300$ & $1,950-650$ & Frio, Ensor, Fairland, Godley, Darl \\
\hline
\end{tabular}


point found during the investigations was a Marcos-like point found on the surface nearby the second feature (Luke 1981:20). Although tentative, researchers indicated the projectile point and the midden may have been part of the same temporal assemblage, which according to their chronology would be the San Marcos Phase.

Very few other artifacts were observed with the two middens, and the site appeared to be one of the typical, deflated burned rock midden sites found in Central Texas and the Trans-Pecos. Although construction of the two investigated features was similar, one significant difference was the use of a natural depression in the bedrock for the building of one of these features. Investigators thought the site would be useful for an inter-site investigation of the IH-10 corridor, but had little research value otherwise (Luke 1981:20). 


\section{Chapter 8}

\section{Site Synthesis and Comparative Analysis}

\section{Mindy Bonine}

\section{Site 41KM225 in a Regional Historic Context}

To reiterate the purpose of this comparative analysis, the following discussion takes as a premise that prehistoric inhabitants of the Upper Llano River watershed research area were mobile hunter-gatherer groups that utilized a diversity of resources across the landscape, and that an analysis of this research area might provide valuable information on whether or not prehistoric peoples concentrated their activities around a particular river basin and adjoining uplands. Two studies were utilized to place site 41KM225 in a regional historic context to try to see if a pattern exists that might answer this question. The first analysis was conducted to determine if site 41KM225 is similar in timeframe of occupation, landscape (or geographic) distribution, and site typology, as other previously recorded sites. The second study compares 41KM225 to other tested archaeological sites in the research area to distinguish similarities and differences within the same three categories. The results of these analyses are described below under each category beginning with chronology, followed by landscape and typology.

\section{Chronology}

Chronology has long been a focus of study for researchers of the Central Texas archaeological region. Some would argue that this fixation has limited the study of other meaningful research issues in the region (Collins 2004:101), but the study of chronology itself has led to several challenges and emphasized specific limitations. In effect, the study of diagnostic lithic tools as indicators of cultural change and their subsequent chronological sequences have been debated for several decades, and several different chronologies have been developed, refined, renamed, replaced, and redeveloped. For the Central Texas archaeological region, a handful of chronologies have been used by most researchers, including Frank Weir's (1976) Ph.D. dissertation on the central Texas Archaic, Dee Ann Suhm and Edward Jelks' (1962) monograph in American Antiquity, Elton Prewitt's $(1981,1985)$ stab at cultural chronology in central Texas, Ellen Sue Turner and Thomas Hester's chronology as represented in A Field Guide to the Stone Artifacts of Texas Indians (1985, rev. 1993 and 1999), LeRoy Johnson and Glenn Goode's (1994) re-examination of the climate of the Holocene and archaeological periods, and most recently Michael Collins' contribution to The Prehistory of Texas (2004).

In the following discussion, no claims are made concerning the validity of any one chronological sequence, nor attempts to contribute to the well-stocked pot of cultural chronology in central Texas. However, in order to conduct a reasonable comparative analysis, discrepancies in chronology need to be addressed. The search for previously recorded sites in the Upper Llano River watershed research area included all recorded sites without reference to when they were recorded. Thus, those researchers who assigned a temporal association to a site may have used Weir's "phases," or Prewitt and others' "periods." Even within the classification of archaeological "periods," there are arguments about whether to use the terms "Late Prehistoric," "Neoarchaic," and "Transitional Archaic," and what time frames each represent. To help mitigate these problems for the purposes 


\section{8-2 Chapter 8}

of conducting this comparative analysis, a recalibration strategy was employed.

Recalibration involved separating sites with associated diagnostic projectile points from sites with no temporal information or non-diagnostic points. The association between the point types found at the site and the temporal period were reviewed and recalibrated to Collins (2004), if necessary. ${ }^{1}$ Collins' chronological sequence is the most current and also includes most of the diagnostic point types (called "archaeological style intervals" in the text) that can be used to make the transition from one chronological sequence to another.

For the analysis of the nine tested sites selected for comparative analysis within the research area, a similar methodology was used. The tested archaeological sites were excavated over several decades, and the researchers used different established chronologies based on the current research at the time. As a result, several chronologies are widely different. In order to really compare and contrast these nine archaeological sites with site 41KM225, the chronologies need to be recalibrated to one sequence. Again, Collins (2004) was used as the "control" to which all other chronologies were calibrated. This was done solely to provide a common baseline by which to conduct the comparative analysis, and is not a critique of the previous chronologies.

It should be noted at this point that all of the temporal periods attributed to both previously recorded sites and tested sites used in this study, including site $41 \mathrm{KM} 225$, were derived from diagnostic projectile points, and not from stratigraphic contexts or radiocarbon assays. Of the tested sites, only the Honey Creek site (41MS32) had radiocarbon samples sent for analysis, and those results contradicted the established projectile point typology to the point where the researchers largely discounted the results (Black et al. 1997). Thus, the association of chronology with sites discussed in this study may not be entirely conclusive, and the sites may have been occupied over much longer, or even entirely different, periods of time.

\section{Patterns in Previously Recorded Sites}

Three-hundred and eleven sites were found in the Upper Llano River watershed research area. Of those sites, only four were not plotted on the Atlas or TARL maps, and only five had no associated information at all. In addition, 10 of the 311 recorded sites were historic-era sites with no prehistoric components. These 10 sites, along with the nine described above, are not included in this analysis, leaving 292 sites.

This segment of the comparative analysis was designed to see if $41 \mathrm{KM} 225$ was occupied at roughly the same time as the rest of the research area. While organizing the data for analysis, researchers realized that only a small portion of the data set was compatible within this research topic. Only 60 previously recorded sites (20.5 percent) contained any temporal information in their records, and among those, only 37 had recorded both the diagnostic projectile points used to determine the probable periods of occupation and the list of the periods of occupation. Of these, only one site, 41KR241, had very specific dates recorded in the file, 7,500-1,750 B.P. (Early to Late Archaic). The remaining 23 sites listed a period of occupation but not the data (i.e., diagnostic tools or other information) used to make that determination. The original research strategy was to incorporate all 60 sites in the analysis of chronology, but the degree of inconsistency and risk of major statistical errors by not using a common baseline chronological

\footnotetext{
${ }^{1}$ It must be noted that only the name of the temporal period was reviewed, not the timeframe associated with it, as
} many times the exact timeframe was not listed on the site forms. 
Table 8.1. Selected Sites in the Upper Llano River Watershed that Contain Chronology Information and Used in Analysis

\begin{tabular}{|c|c|c|c|c|c|}
\hline Site & Site Type & $\begin{array}{l}\text { Archaeological } \\
\text { Periods }\end{array}$ & Diagnostic Tools & \begin{tabular}{|c} 
Period Based on \\
Collins (2004:fig 3.9a)
\end{tabular} & $\begin{array}{l}\text { Common in } \\
\text { Central Texas? }\end{array}$ \\
\hline 41KM91 & Open Campsite & Unknown & Possible Plainview & Paleoindian & yes \\
\hline $41 \mathrm{KM} 137$ & $\begin{array}{l}\text { Lithic Procurement/ } \\
\text { Production }\end{array}$ & Early to Mid Archaic & $\begin{array}{l}\text { Plainview, Stemmed, } \\
\text { and Corner-notched }\end{array}$ & $\begin{array}{l}\text { Paleoindian to Early } \\
\text { Archaic }\end{array}$ & yes \\
\hline $41 \mathrm{KM} 224$ & Open Campsite & Early Archaic & Gower & Early Archaic & yes \\
\hline 41KM159 & Burned Rock Midden & Early Archaic & Nolan and Gower & Early to Middle Archaic & yes \\
\hline 41KM131 & Open Campsite & Early to Middle Archaic & $\begin{array}{c}\text { Pedernales, Angostura, } \\
\text { and Frio }\end{array}$ & Early and Late Archiac & yes \\
\hline $41 \mathrm{KM} 126$ & Open campsite & Unknown & $\begin{array}{c}\text { Uvalde-like, Ensor, Early } \\
\text { Triangular }\end{array}$ & Early and Late Archiac & yes \\
\hline 41KM114 & Burned Rock Midden & Early to Middle Archaic & $\begin{array}{c}\text { Martindale, Andice, Bell- } \\
\text { like, Early Triangular, } \\
\text { Nolan, Bulverde, and } \\
\text { Pedernales }\end{array}$ & Early to Late Archaic* & yes \\
\hline $41 \mathrm{KR} 241$ & Sinkhole Cemetery & $7,500-1,750$ в.P. & Dart Points and Beads & Early to Late Archaic & Unknown \\
\hline 41KM152 & Burned Rock Midden & Early to Middle Archaic & Nolan & Middle Archaic & yes \\
\hline $41 \mathrm{KM} 215$ & Burned Rock Midden & Middle Archaic & Travis & Middle Archaic & yes \\
\hline $41 \mathrm{KM} 8$ & Burned Rock Midden & Unknown & Travis-like dart points & Middle Archaic & yes \\
\hline $41 \mathrm{KM} 214$ & Burned Rock Midden & Early to Late Archaic & Pedernales and Nolan & Middle to Late Archaic & yes \\
\hline 41KM123 & Open Campsite & Archaic & \begin{tabular}{|c|} 
Bell, Kinney, \\
Pedernales, Castroville, \\
Fresno, and Harahay \\
Knives
\end{tabular} & Middle to Late Archaic* & yes \\
\hline $41 \mathrm{KM} 146$ & Burned Rock Midden & Early to Late Archaic & $\begin{array}{l}\text { Nolan, Langtry, } \\
\text { Bulverde, Pedernales, } \\
\text { Marcos, and Montell }\end{array}$ & Middle to Late Archaic* & $\begin{array}{l}\text { Langtry } \\
\text { uncommon }\end{array}$ \\
\hline 41KM150 & Burned Rock Midden & Middle Archaic & Langtry & Middle to Late Archaic* & Uncommon \\
\hline $41 \mathrm{KM} 7$ & Burned Rock Midden & Archaic & Gary-like & $\begin{array}{c}\text { Middle Archaic to Late } \\
\text { Prehistoric }\end{array}$ & No, East Texas \\
\hline 41KM56 & Open Campsite & Archaic & $\begin{array}{c}\text { Pedernales, Bulverde, } \\
\text { and Montell }\end{array}$ & Late Archaic & yes \\
\hline 41KM148 & Burned Rock Midden & Early Archaic & Bulverde & Late Archaic & yes \\
\hline $41 \mathrm{KM} 223$ & Burned Rock Midden & Early to Middle Archaic & Bulverde & Late Archaic & yes \\
\hline 41KM132 & Open Campsite & Late Archaic & Ensor & Late Archaic & yes \\
\hline $41 \mathrm{KM} 143$ & Burned Rock Midden & Late Archaic & Marcos & Late Archaic & yes \\
\hline $41 \mathrm{MS} 49$ & Open Campsite & Late Archaic & Ensor & Late Archaic & yes \\
\hline 41KM151 & $\begin{array}{l}\text { Lithic Procurment/ } \\
\text { Burned Rock Midden }\end{array}$ & Middle Archaic & Pedernales & Late Archaic & yes \\
\hline $41 \mathrm{KM} 17$ & Burned Rock Midden & Not Reported & Marshall & Late Archaic & yes \\
\hline 41KM76 & Lithic Scatter & Unknown & Possible Frio Points & Late Archaic & yes \\
\hline $41 \mathrm{KM} 29$ & Open campsite & Unknown & Pedernales & Late Archaic & yes \\
\hline $41 \mathrm{KM} 15$ & Lithic Scatter & Late Archaic & Probable Shumla & Late Archaic* & No, South Texas \\
\hline $41 \mathrm{KM} 216$ & $\begin{array}{l}\text { Lithic Procurement/ } \\
\text { Production }\end{array}$ & Middle-Late Archaic & Marshall and Palmillas & Late Archaic* & yes \\
\hline $41 \mathrm{KM} 16$ & Open Campsite & Archaic/Late Prehistoric & Montell and Perdiz & $\begin{array}{l}\text { Late Archaic to Late } \\
\text { Prehistoric }\end{array}$ & yes \\
\hline 41KM115 & Open Campsite & $\begin{array}{c}\text { Late and/or Transitional } \\
\text { Archaic, Late } \\
\text { Prehistoric }\end{array}$ & Frio, Scallorn-like & $\begin{array}{l}\text { Late Archaic to Late } \\
\text { Prehistoric }\end{array}$ & yes \\
\hline
\end{tabular}


Table 8.1. Selected Sites in the Upper Llano River Watershed that Contain Chronology Information and Used in Analysis, continued

\begin{tabular}{|c|c|c|c|c|c|}
\hline Site & Site Type & $\begin{array}{c}\text { Archaeological } \\
\text { Periods }\end{array}$ & Diagnostic Tools & $\begin{array}{c}\text { Period Based on } \\
\text { Collins (2004:fig 3.9a) }\end{array}$ & $\begin{array}{c}\text { Common in } \\
\text { Central Texas? }\end{array}$ \\
\hline $41 \mathrm{KM} 217$ & Burned Rock Midden & $\begin{array}{c}\text { Late Archaic/Late } \\
\text { Prehistoric/Neo- } \\
\text { American }\end{array}$ & $\begin{array}{c}\text { Ensor, Perdiz, and } \\
\text { Edwards }\end{array}$ & $\begin{array}{c}\text { Late Archaic to Late } \\
\text { Prehistoric }\end{array}$ & yes \\
\hline $41 \mathrm{KM} 154$ & $\begin{array}{c}\text { Lithic Procurement/ } \\
\text { Production }\end{array}$ & Late Archaic & Edgewood & $\begin{array}{c}\text { Late Archaic to Late } \\
\text { Prehistoric }\end{array}$ & Uncommon \\
\hline $41 \mathrm{KM} 153$ & Burned Rock Midden & $\begin{array}{c}\text { Late Archaic/Late } \\
\text { Prehistoric/Neo- } \\
\text { American }\end{array}$ & $\begin{array}{c}\text { Edgewood and Possible } \\
\text { Guadalupe Tool }\end{array}$ & $\begin{array}{c}\text { Late Archaic to Late } \\
\text { Prehistoric }\end{array}$ & Uncommon \\
\hline $41 \mathrm{MS} 23$ & Rock Shelter & Late Prehistoric & 5 Perdiz & Late Prehistoric & yes \\
\hline $41 \mathrm{KM} 124$ & Burned Rock Midden & $\begin{array}{c}\text { Late Prehistoric- } \\
\text { Middle Archaic }\end{array}$ & $\begin{array}{c}\text { Perdiz and Scallorn Like } \\
\text { Arrow Point }\end{array}$ & Late Prehistoric & yes \\
\hline $41 \mathrm{KM} 28$ & Lithic Scatter & Not Reported & Perdiz & Late Prehistoric & yes \\
\hline $41 \mathrm{KM} 6$ & $\begin{array}{c}\text { Open Campsite/ } \\
\text { Lithic Procurement }\end{array}$ & Unknown & Cliffton, 14 arrowpoints & Late Prehistoric* & yes \\
\hline
\end{tabular}

*Note: Several of these projectile points are not referenced in the "archeological style periods" in Collins (2004:fig 3.9a) and their associated archaeological periods were derived by Turner and Hester (1999) and recalibrared to Collins (2004).

sequence made it clear that only the 37 sites could be used in the analysis. Table 8.1 shows the original periods of occupation listed by the original researcher of those sites used in this analysis, the recalibrated dates based on Collins (2004), and the diagnostic tools found at each site.

Prehistoric occupation in central Texas has been recorded from the Paleoindian period through the Late Prehistoric period. Within these timeframes, there are distinct diagnostic tools within the Central Texas archaeological region, which has enabled archaeologists to make connections between artifacts and occupation periods. There are approximately 35 "archaeological style intervals" listed by Collins (2004:fig. 3.9a) for the Central Texas archaeological region, and 21 of those types have been recorded in the 37 sites in the research area that list diagnostic tools, including Andice, Angostura, Bell, Bulverde, Castroville, Edwards, Ensor, Frio, Gower, Kinney, Marcos, Marshall, Martindale, Montell, Nolan, Pedernales, Perdiz, Plainview, Scallorn, Travis, and Uvalde. A few points were found at these 37 sites that were not in Collins' list, but are known to exist in central Texas according to Turner and Hester (1999). They include Clifton, Early Triangular, Fresno, and Palmillas. Some points were found in the 37 sites that are uncommon to the region but not unheard of; they consist of Langtry and Edgewood points. Finally, only two archaeological sites with point information in the research area contained diagnostic points that are generally associated with other areas of the state, including Shumla point from south Texas (41KM15) and a Gary point from east Texas (41KM7).

Although 37 sites is a rather small data set to make generalizations about the intensity of settlement in the Upper Llano River watershed research area over various time periods, one trend may prove to be significant to understanding cultural change in the Central Texas archaeological region. Of those sites that have projectile point information and can be attributed to a particular occupation period, there are slightly more sites dating to the Late Archaic or Late Archaic to Late Prehistoric than any site with Paleoindian to Middle Archaic period components, by a ratio of 1.3:1. At first glance this would mean that the 
research area was settled far more heavily in the Late Archaic and Late Prehistoric than in earlier periods, but with such a small data set this conclusion may be erroneous. The preponderance of later period sites in the research area may be more of a factor of post depositional processes (younger sites are better preserved and pre-Late Archaic have been subjected to more erosional events) than actual numbers of sites, so this pattern should be considered very tentatively while additional data is compiled.

Another intriguing pattern was found that may be useful in future analyses. The number of sites that span two or more occupation periods (multi-component) is roughly the same as those sites that show evidence of occupation in only one period, about $0.8: 1$. This sets up a possible relational database that could be used to better interpret both kinds of sites. Typically, a multi-component site with good stratigraphic separation can provide information about both individual occupation periods and cultural change between occupation periods (Collins 2004; Ferring 1986; and Johnson 1987). This information can then be correlated to date sites that have been occupied within a narrower time frame, i.e., a single component site. The singlecomponent site can in turn provide additional depth of understanding to a particular occupation period that the multi-component site could not. ${ }^{2}$ If there is a roughly equal ratio of multi-component sites to single component sites, there is a much better chance to make connections than if there were only a few multi-component sites and numerous single component sites. Even taking into account that many multi-component sites have poor stratigraphic separation, the above ratio suggests it is still possible to obtain enough examples of stratigraphically distinct multicomponent sites and single component sites to make substantial connections.
Comparing the data from the 37 sites in Table 8.1 to the points recovered from 41KM225 (Pedernales-like point, a Early Triangular-like point, and a Paisano-like point), the first observation is that a Paisano point has not been located anywhere else in the Upper Llano River watershed research area. Indeed, no other points from the Trans-Pecos region have been recovered from any site in the research area, although one point from east Texas (Gary) and one from south Texas (Shumla) have been recovered. Gary points have a long associated temporal range, from the Middle Archaic to the Late Prehistoric, but the Shumla and Paisano points both date to the Late Archaic (Collins [2004] calibration; Transitional Archaic according to Turner and Hester [1999]; ca. 2,150-1,350 B.P.). Interesting extrapolations about group mobility through central Texas could be invented with this scant information, but there is currently not enough data to make any connections. Only their presence is noted at this point.

The Pedernales point is a well represented type in the Upper Llano River watershed research area, with seven other sites in the data set containing at least one Pedernales point. However, the Early Triangular point is not as well represented, with only two other sites in the research area recording this type of point. Nevertheless, both are known to be rather common in the Central Texas archaeological region, and their presence at site 41KM225 is not unusual. Likewise, the timeframes associated with these points, the Middle Archaic for the Early Triangular (according to Collins [2004]; Early Archaic according to Turner and Hester [1999]; 5,650-5,550 B.P.) and the middle Late Archaic for the Pedernales point (ca. 3,300-2,300 B.P. according to Collins [2004]), are also well represented in the research area.

\footnotetext{
${ }^{2}$ For example, a rockshelter may be able to provide good stratigraphic data and temporal associations with diagnostic materials, but does not explain much about large habitation activity areas. An open campsite dating to one of the periods at the rockshelter would be able to make those types of connections.
} 


\section{Patterns in Tested Archaeological Sites}

Of the nine tested archaeological sites within the Upper Llano River watershed selected for study, only one contains evidence of a Late Paleoindian occupation (Honey Creek Site), five have Late Prehistoric occupations, and all but one contains evidence of at least one Archaic period occupation (41KM90 has no known chronological sequence). The chronology of each tested site is presented in Table 8.2 below, using the terms the original researchers used.

Table 8.2. Chronology of Selected Tested Sites

\begin{tabular}{|c|c|c|}
\hline & Site & Chronology \\
\hline 1 & $41 \mathrm{KM} 3$ & Late Paleoindian to Late Prehistoric \\
\hline 2 & $41 \mathrm{KM} 61$ & San Geronimo to Neo-American \\
\hline 3 & $41 \mathrm{KM} 62$ & Clear Fork to Neo-American \\
\hline 4 & $41 \mathrm{KM} 90$ & Unknown \\
\hline 5 & $41 \mathrm{KM} 115$ & Late Archaic to Late Prehistoric \\
\hline 6 & $41 \mathrm{KM} 126$ & Early and Late Archaic \\
\hline 7 & $41 \mathrm{MS} 32$ & Late Paleoindian to Late Prehistoric \\
\hline 8 & $41 \mathrm{SU} 20$ & Early Archaic \\
\hline 9 & $41 \mathrm{SU} 18$ & San Marcos \\
\hline 10 & $41 \mathrm{KM} 225$ & Middle to Late Archaic \\
\hline
\end{tabular}

Comparatively, Table $8.3^{3}$ provides the original chronological sequences of the nine tested sites used by the original researchers in terms of radiocarbon years (B.P.) (derived with help from Tables 7.6-7.9), and also presents the recalibrated dates based on Collins (2004). The sites, with the exception of the Honey Creek Site (41MS32), did not have any radiocarbon dates to provide an absolute date for any site component, thus diagnostic projectile points were used to derive the original chronology as well as the recalibrated chronology.

As seen in Table 8.3, the tested sites selected for comparative analysis are quite variable in their known chronologies, emphasizing the extremely long time in which the Central Texas archaeological region has been occupied by prehistoric peoples. There are very few patterns that can be discerned by the temporal ranges exhibited by the tested sites, except for the particularly long occupations at the Red Creek site and the Honey Creek site, which are both close to the Llano River (for further discussion of these sites, see the Landscape section below). Other sites have comparatively short occupation periods, but they have been occupied at different times from the Early Archaic to the Late Archaic, and even into the Late Prehistoric. Site 41KM225 appears to be one of the latter.

In terms of the similarities or differences in the recovery of diagnostic projectile points among the nine tested sites and site 41KM225, one is immediately struck by the wide differences in the number of projectile point varieties found at the sites. The tested sites either have three or less types (including 41KM225) or they have seven or more (see Table 7.6). Generally, the more projectile point types found, the longer the time frame of occupation, but there are some interesting variations. The Honey Creek site and the Red Creek site, both with the longest occupation periods, have 18 and nine different projectile point types, respectively. Site $41 \mathrm{KM} 61$, on the other hand, has almost as many point types $(\mathrm{n}=15)$ as Honey Creek, but has been correlated to a smaller time frame of occupation. Sites 41KM115, 41KM126, 41SU20, 41SU18, and 41KM225 all have a very small number of projectile point varieties, and thus are restricted to small identifiable periods of occupation.

In any analysis concerning chronology, the conclusions reached carry much more weight if there is a high degree of supporting data. To determine the possible lengths of habitation and

\footnotetext{
${ }^{3}$ Table 8.3 also includes information about the landscape setting of each site, indicated by the color coding. The description of the landscape settings are not presented here, but are described in the following Landscape section.
} 


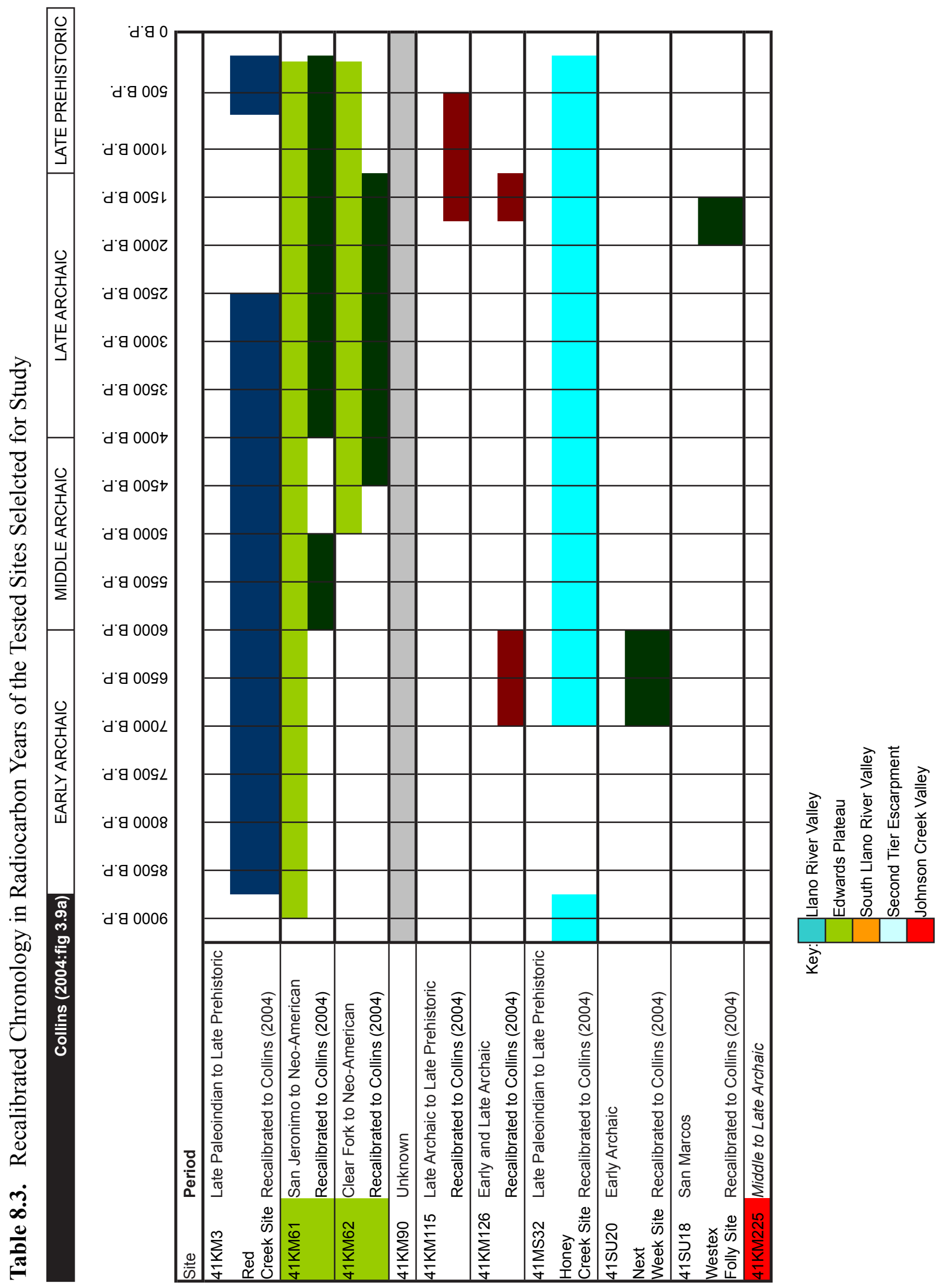


time-periods of occupation at a site, the high degree of supporting data can come in the form of large quantities of the same type of artifact (consider finding 10 Pedernales points at a site instead of one), or through groups of artifacts dating to the same time period (as in finding several Nolan and Travis points together at a site). Although 41KM225 is not a site type in which long-term site residence within any period is supported (the discovery of one artifact per period only confirms a minimum of one incident of occupation), sites possessing this information have been located in the Upper Llano River watershed research area.

\section{LANDSCAPE SETTING}

In a discussion of prehistoric cultural practices in a regional context, it is logical to include a discussion of the horizontal pattern of site distribution across a wider landscape as well as a discussion of temporal associations. Interesting patterns may arise from a recombination of the data set to emphasize where they are located geographically, and some behaviors of mobile hunter-gatherer groups can only be seen using this broader method of analysis (Binford 1983:109-143; Black et al. 1997:31). In fact, one could argue that this type of spatial analysis is one way to get the most out of the limited information gathered from 41KM225 (and many other deflated archaeological sites in this region) as its temporal associations (a fundamental element of archaeological research) are weakened by a lack of clear vertical stratigraphic zones with diagnostic artifacts and radiocarbon samples.

In looking at the landscape of the Upper Llano River watershed, the foremost observation is the change in setting from the west to the east, as one can easily see the comparatively flat Edwards Plateau to the west incised by the tributaries of the Llano River, and eventually the Llano River itself(Figure 8.1). These waterways form a dendritic network of deeply incised channels leading dramatically down to larger creek valleys, which combine and widen to several miles as the watercourses merge into the Llano River towards the east side of the research area. However, even though the valleys surrounding the sizable rivers of the Upper Llano River watershed are wide, the floodplains of each river are very narrow, since the waterways continue to erode the ancient limestone at a rapid rate, not allowing for gradual sedimentation. In fact, a second tier of escarpments within the broad valley have been formed by the Llano and James rivers towards the east end of the research area. Where the Llano and James rivers merge, the landscape has transformed to the rolling hills of the Llano Uplift.

In their definitive work Hot Rock Cooking on the Greater Edwards Plateau, Stephen Black, Linda Ellis, Darrell Creel, and Glenn Goode included in their analysis of four burned rock midden sites in Central Texas an 18-county study area crossing the Edwards Plateau from north-tosouth (Black et al. 1997:31-41). This study area includes a large portion of the Upper Llano River watershed, including areas in Kimble, Edwards, Real, Kerr, Menard, and Mason counties (Figure 8.2). Their analysis included an examination of the distribution of burned rock midden sites recorded as of July 1993 in the study area, ${ }^{4}$ and these site locations were compared to areas where sotol and oaks are known to grow (Black et al. 1997:91-93). Sotol and oak acorns are believed by some to be the principal foodstuffs cooked in burned rock middens, thus the reason

\footnotetext{
${ }^{4}$ As of July 1993, 21 of 118 recorded sites (18\%) contained burned rock middens in Kimble County, 62 of 122 prehistoric sites (51\%) contained burned rock middens in Edwards County, 30 of 61 sites (49\%) contained burned rock middens in Real County, 193 of 470 sites (41\%) contained burned rock middens in Kerr County, 2 of 22 sites (9\%) contained burned rock middens in Menard County, and 9 of 40 sites (23\%) contained burned rock middens in Mason County.
} 


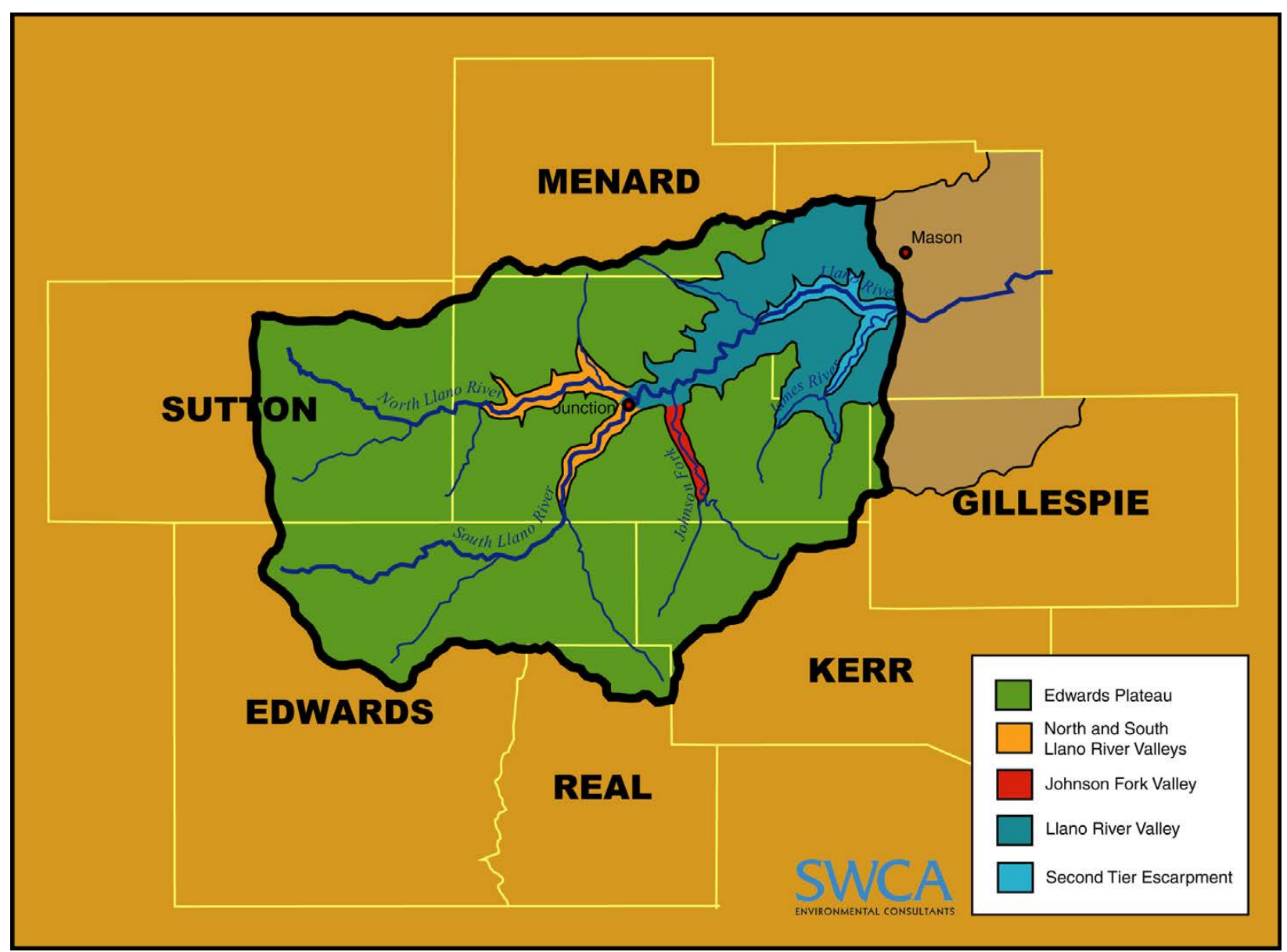

Figure 8.1. Geographic and landscape settings within the Upper Llano River watershed research area.

for the choice of these particular species. They also included in their analysis the distribution of bedrock type, indicating that burned rocks middens are almost always comprised of burned limestone or sandstone and not granite or other igneous rocks (Black et al. 1997:93).

Black et al. (1997) determined that sotol coverage did not necessarily correspond to the location of burned rock middens, but that middens were almost entirely within the coverage of oak savanna. The small portion of the 18-county study area that have granitic outcrops contain almost no burned rock middens, suggesting granitic rocks are unsuitable for hot rock cooking. This study also found that when the distributions of sotol, oak savanna, and site percentages by county were combined, the highest percentages of burned rock midden sites (including Edwards, Kerr, and Real Counties) are located in areas where stool and oak savanna occur together (Black et al. 1997:98). The Upper Llano River watershed research area used in this study is almost entirely subsumed in this area. Thus, it is anticipated there will be a significant percentage of sites with burned rock middens in the research area. In fact, about 82 of the 311 previously recorded sites in this area contain burned rock middens, or about 26.4 percent. See a further discussion below. 


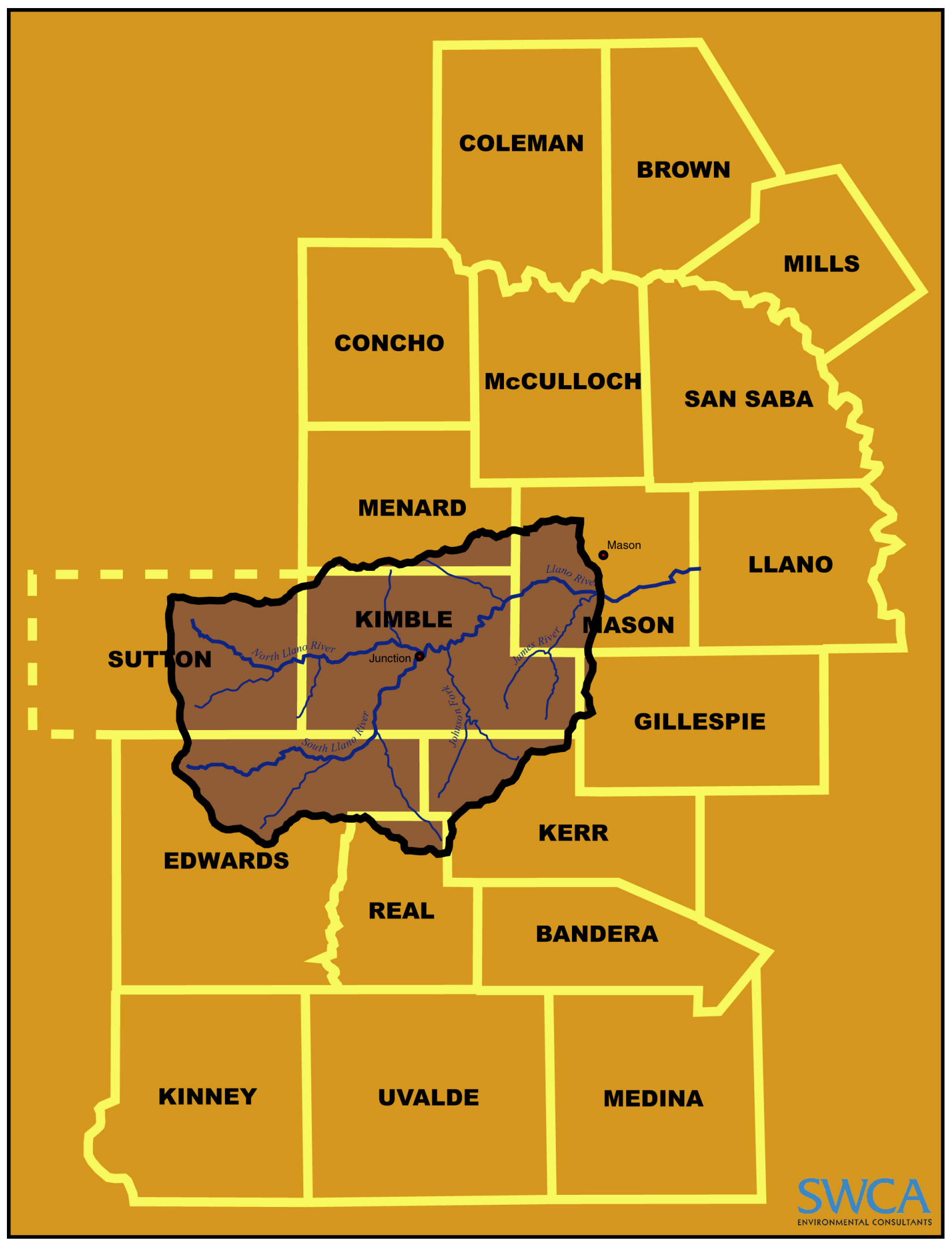

Figure 8.2. Overlapping study areas of the 18-county study area used by Black et al. (1997) and the Upper Llano River watershed research area. 


\section{Patterns in Previously Recorded Sites}

With only 311 previously recorded archaeological sites as of May 2007 in a 3,150 square mile area (over 800,000 hectares), a useful landscape-oriented comparative analysis of such a small data set would be tentative at best and completely erroneous at worst. Add to this the fact that the majority of the archaeological investigations in the Upper Llano River watershed have been conducted as a result of modern development, including the construction of roads, parks, urban areas, and the installation of related utilities. Thus, it is likely that plotting the recorded archaeological sites on a map (Figure 8.3) says more about the pattern of twentieth century development than habitation preferences of mobile prehistoric hunter-gatherer groups.
However, a few interesting, if not surprising, patterns can be seen in this available data set. Thus far the largest sites (50 acres or larger) have been found on terraces overlooking streams or rivers, or are located on terraces at the confluence of two watercourses (e.g., 41KM52, 41KM105, 41KM56, 41KM2, 41KM60, 41KM61, 41 KM62, 41 MS54, etc.). In addition, although most of the archaeological sites are located on landforms near sources of water (either currently flowing rivers or formerly perennial streams), other archaeological sites have been found on escarpments in the more arid areas of the Edwards Plateau.

Unfortunately, a comparative analysis of how prehistoric peoples used the upper vs. lower

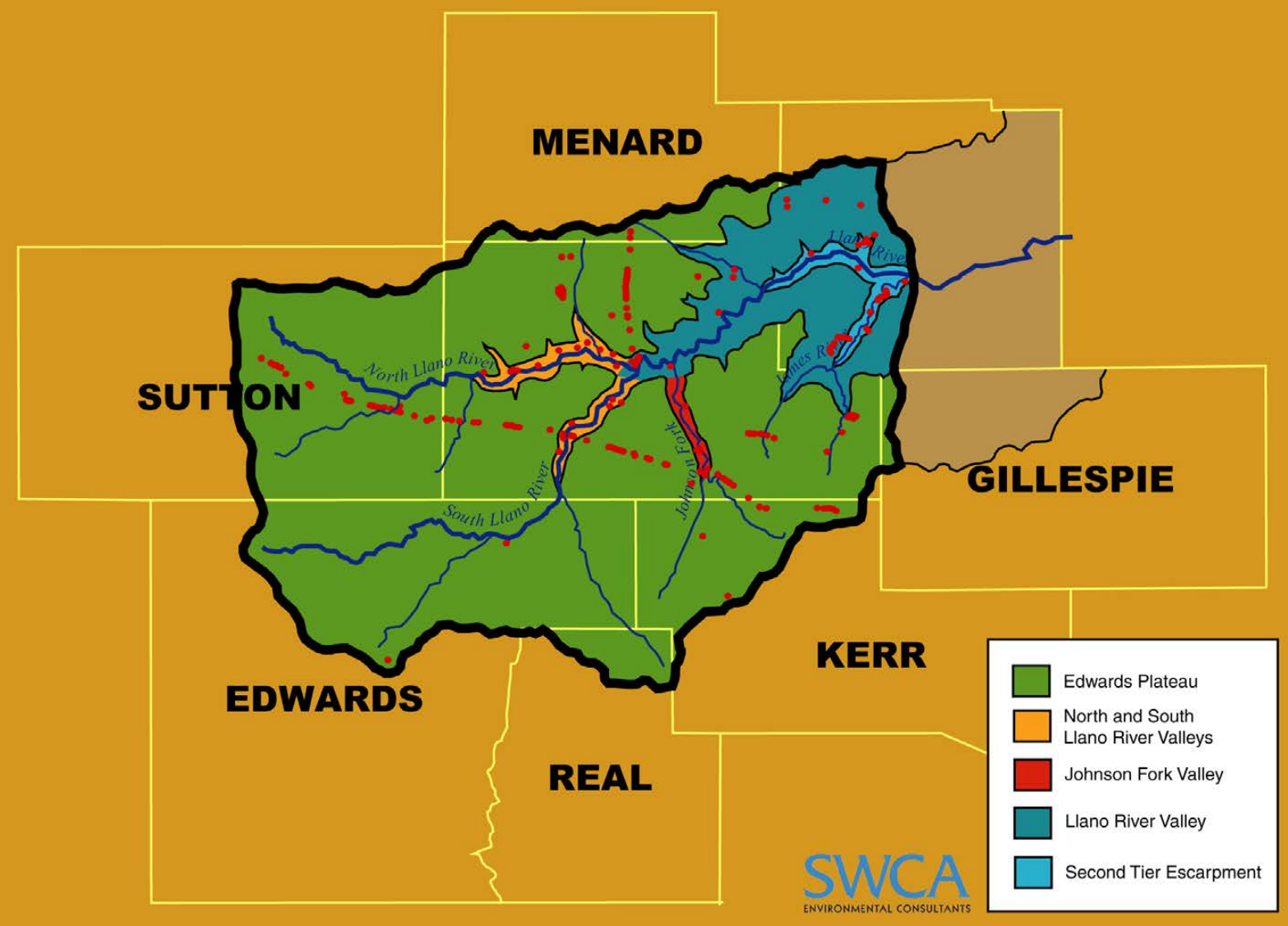

Figure 8.3. Previously recorded archaeological sites within the Upper Llano River watershed research area 


\section{8-12 Chapter 8}

elevations of the Upper Llano River watershed, or even different landscape settings, cannot be assessed based on the current data. The number of previously recorded sites within each landscape setting is too few to make any statistically significant comparisons. However, some general comments can be made from the data thus far, which may prove to be a useful observation. Although not prevalent throughout the research area, there is some evidence for the clustering of sites that have similar components. For example, sites with burned rock features appear to cluster together and sites with lithic scatters or lithic procurements sites appear to cluster together. In addition, such clusters appear to be associated with specific topographic features (e.g., a bend in a river, or across the top of a finger of land, or some other topographical feature). In the upland areas on the west side of Johnson Fork and site 41KM225 there are several clusters of lithic scatters or lithic procurement areas, but it is not known if these are connected with site $41 \mathrm{KM} 225$ in any way (there is no information other than proximity to make a correlation). This clustering may be a culturally meaningful phenomenon; although it may simply be the result of expediently processing materials procured at or near the site.

\section{Patterns in Tested Archaeological Sites}

Of the nine tested archaeological sites within the Upper Llano River watershed selected for study, four are located in the valleys below the Edwards Plateau escarpments, one is situated on a rolling second-tier escarpment above the Llano River, and four were seen on the Edwards Plateau itself. The location on the landscape setting of each tested site is presented in Table 8.4.

The tested sites do provide good coverage across the landscape: the Honey Creek Site (41MS32) is located towards the eastern edge of the research area on the second tier of escarpments above the Llano River; site 41KM3 is situated
Table 8.4. Landscape of Selected Tested Sites

\begin{tabular}{|c|c|c|}
\hline & Site & Landscape Setting \\
\hline 1 & $41 \mathrm{KM} 3$ & Llano River Valley \\
\hline 2 & $41 \mathrm{KM} 61$ & Edwards Plateau \\
\hline 3 & $41 \mathrm{KM} 62$ & Edwards Plateau \\
\hline 4 & $41 \mathrm{KM} 90$ & South Llano River Valley \\
\hline 5 & $41 \mathrm{KM} 115$ & South Llano River Valley \\
\hline 6 & $41 \mathrm{KM} 126$ & South Llano River Valley \\
\hline 7 & $41 \mathrm{MS} 32$ & Second Tier Escarpment \\
\hline 8 & $41 \mathrm{SU} 20$ & Edwards Plateau \\
\hline 9 & $41 \mathrm{SU} 18$ & Edwards Plateau \\
\hline 10 & $41 \mathrm{KM} 225$ & Johnson Creek Valley \\
\hline
\end{tabular}

in the broad valley formed by the Llano River towards the northern end of the research area; sites 41KM61 and 41KM62 are located on the sides of two fingers of the Edwards Plateau that were formed by Llano River tributaries close to the southern end of the research area; sites 41KM90, 41KM115, and 41KM126 area all located in a narrow valley of the South Llano River, with escarpments rising on either side of the valley in the middle of the research area; and sites 41 SU2 0 and 41SU18 are situated near the North Llano River in the higher elevations of the research area on the west side (Figure 8.4). Site $41 \mathrm{KM} 225$ is located between the 41KM61/62 and $41 \mathrm{KM} 90 / 115 / 126$ groupings, near the center of the research area.

The nine tested archaeological sites were organized by their location on the landscape (according to Table 8.4), and several site attributes were compared to see if any patterns emerged. Here too no clear-cut patterns emerged. Site size, depth of archaeological deposits, and periods of occupation are all too variable between the landscape groups to observe discernable patterns. However, the observable differences in the number of burned rock features in each landscape group appear to hint at some patterning. If the sites at the lower elevations, e.g., the Llano River Valley and Second Tier Escarpment, 


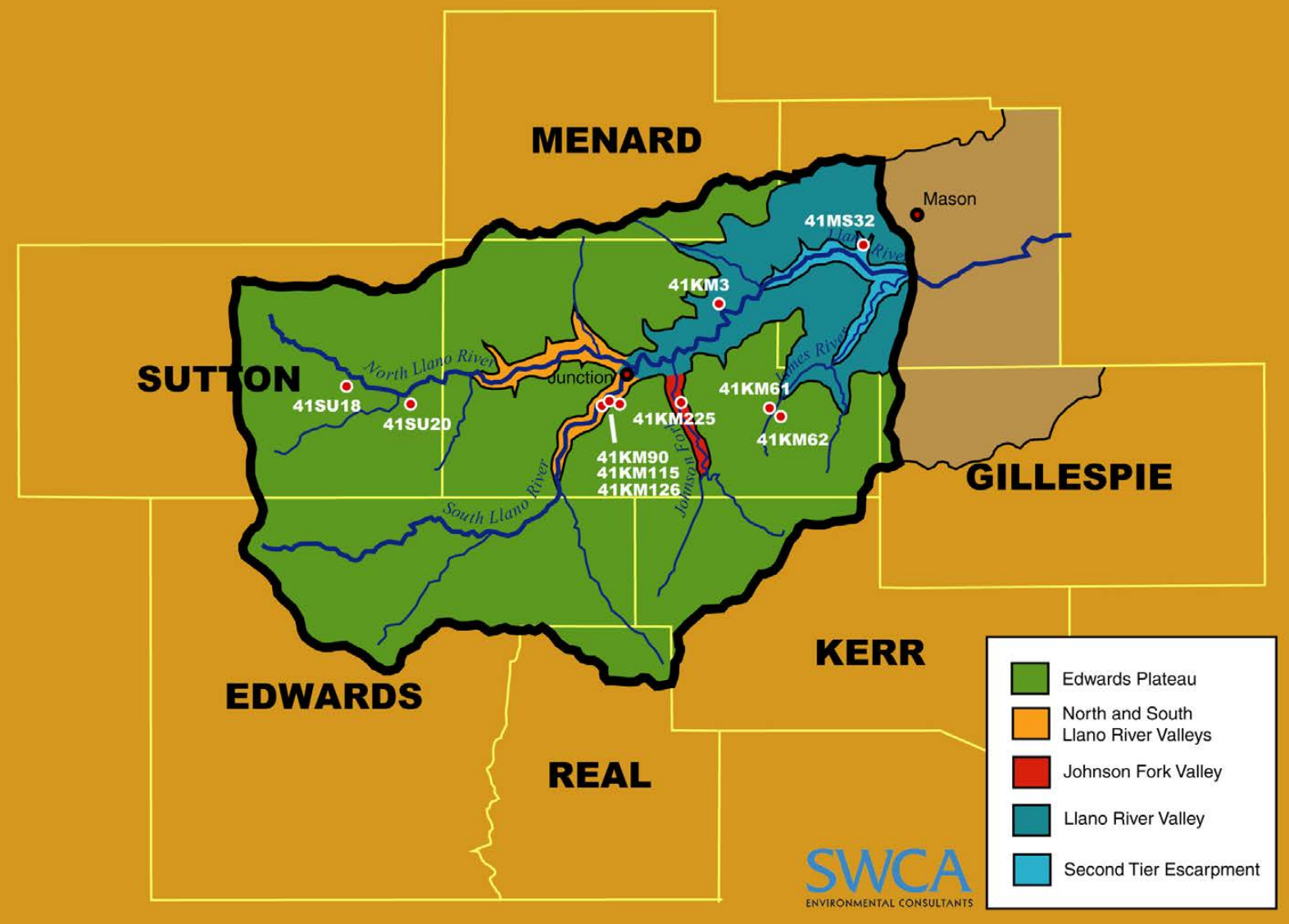

Figure 8.4. Locations of tested archaeological sites selected for study in the Upper Llano River watershed research area.

are combined ( 1 and 7 on Table 8.4, the Honey Creek and Red Creek sites), they have a total of 41 features ( 25 hearths, three middens, and 13 burned rock scatters). This is about a 20:1 ratio of features per site. The other river valley sites $(4,5,6$, and 10 on Table 8.4) located at higher elevations, have a total of 15 features (13 hearths, 1 midden, and 1 burned rock scatter). This is a ratio of about $4: 1$ features per site. The sites on the Edwards Plateau (2, 3, 8, and 9 on Table 8.4 ), have a total of 12 features (nine middens, two hearths, and one lithic procurement area), a ratio of $3: 1$ features per site. ${ }^{5}$

These data suggests that archaeological sites nearest the Llano River (a primary waterway) have the most features, which can be interpreted to be either much longer periods of site occupation by prehistoric peoples and/or very large scale hot rock cooking operations involving big groups. The first idea is corroborated by the evidence from an analysis of diagnostic artifacts

\footnotetext{
${ }^{5}$ Perhaps a more telling analysis would be to incorporate the excavated volume at each site, as more excavated material would possibly reveal more features within each site. This caution is particularly relevant to the Honey Creek Site, which had both the highest excavated volume $\left(60.67 \mathrm{~m}^{3}\right.$ of hand excavated units) and the greatest number of features. However, the excavated volume for the majority of the other tested sites was not suitably recorded, nor could it be derived from what information was presented. Thus, this data was not available and could not be included.
} 


\section{8-14 Chapter 8}

and radiocarbon samples at the Honey Creek and Red Creek sites; they are the two longest occupied sites of the nine selected for the data set (Table 8.3). However, there is enough discrepancy in the classifications of different features by the researchers investigating the sites, as well as the difference in scale of the archaeological investigations, that these correlations are considered tentative. The sites with the largest number of features, the Red Creek site and the Honey Creek site (41KM3 and 41KM32, respectively) have been investigated more thoroughly than the others, and additional research may increase the number of features at sites located near secondary or tertiary waterways away from the Llano River.

\section{SItE TyPOLOGY}

An unfortunate aspect of site 41KM225 is that the only known feature at the site, a burned rock midden, has been largely destroyed by the construction of FM 2169. Only the peripheral edge of it can be seen in the profile on the east side of the roadway. The lack of an intact burned rock midden does not entirely inhibit identifying 41KM225 as a certain site type, but does hinder the researcher's ability to classify the type of midden that was there and perhaps learn more about the activities conducted by the inhabitants. In addition, areas of the site outside of the current ROW of FM 2169 were not accessible for the testing investigations, and other site attributes may be present that have not yet been found and recorded. This scenario is not unusual, as it is rarely the case that the entire horizontal and vertical extents of archaeological sites are investigated. In fact, all nine of the tested archaeological sites in the research area have had only small portions of the overall site area tested.

However, enough information about site $41 \mathrm{KM} 225$ has been recorded to give a general sense of its typology in a wider regional context. Site typology is a general classification system made of descriptive terms, and although attempts have been made to regulate the diversity of terminology used to describe sites (i.e., TexSite, the program used to record newly discovered sites and revisits to existing sites, has a drop down list of specific terms for site type), older site forms and associated data have a wide variety of terms meaning many different things. An attempt was made in this study to synthesize the data obtained on the previously recorded sites in the Upper Llano River watershed research area, and the terms were distilled into 14 types. By necessity some of the terms used by the original researchers had to be modified to fit into the list, but the original data (and terms used by the researchers) was utilized as much as possible. ${ }^{6}$ As described in Chapter 7, the data set compiled for the comparative analysis were first categorized by "landform," and within these categories, the data was organized by the following site types: open campsite with burned rock midden, open campsite (including those with hearths or burned rock scatters), lithic procurement/production, quarry, lithic scatter, burial, pictographs, rockshelter, rockshelter/midden, sinkhole, mortarhole, multi-activity, isolate, and unknown. The discussion below is simply the beginning of possible interpretations concerning cultural practices of prehistoric peoples in the research area.

\footnotetext{
${ }^{6}$ This method of data analysis has likely created some margin of error, as some researchers use different terms to mean the same type of site, and the same term to mean different site types. This may be particularly true for "open campsite," which may or may not include evidence of hearth or other burned rock features. It is hoped that this margin of error is minimal enough to conduct realistic analyses.
} 


\section{Patterns in Previously Recorded Sites}

Site 41KM225 is well represented as an open campsite located on a terrace overlooking a watercourse within the Upper Llano River watershed. Of the 292 recorded prehistoric sites in the watershed with location information, 154 of them, or about 52.7 percent, are prehistoric sites located on terraces. Of these, 50 (32.5 percent) are open campsites with burned rock middens, 36 (23.4 percent) are open campsites with hearth features or scatters of burned rock, 19 (12.3 percent) are lithic scatters, 14 (9.1 percent) are lithic procurement and production areas, and 35 (22.7 percent) are a combination of rockshelters, mortar holes, multi-component sites, isolated finds, and sites with no data other than their location (Table 8.5).

Alternatively, about 138 sites (47.3 percent) are located in other geographic areas, including hillslopes ( $89 ; 30.5$ percent), hilltops (37; 12.7 percent), hilltop/slope $(4 ; 1.4$ percent), and upland drainages $(8 ; 2.7$ percent) (Table 8.5$)$.

Several patterns can be seen from analysis of the data, although the meaning of such patterns is still tentative. First, the locations of burned rock middens in the Upper Llano River watershed research area are largely on terraces $(\mathrm{n}=50)$, followed by hillslopes $(\mathrm{n}=12)$ and upland drainages $(n=6)$. The ratio of terraces to other areas is almost $3: 1$. No campsites with burned rock middens were found on hilltops in the research area. Open campsites with hearths or burned rock scatters have an even higher ratio of terrace locations $(n=36)$ to other areas (in this case hillslopes, hilltops, and upland drainages, $\mathrm{n}=6$ ), close to $6: 1$. Sites with multiple activities, including habitation areas, lithic procurement and processing areas, burned rock features, or quarries, are more evenly distributed (and far

Table 8.5. Matrix of Previously Recorded Archaeological Sites in the Upper Llano River Watershed

\begin{tabular}{|c|c|c|c|c|c|c|c|c|c|c|c|c|c|c|c|}
\hline & 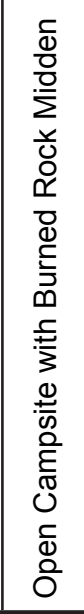 &  & 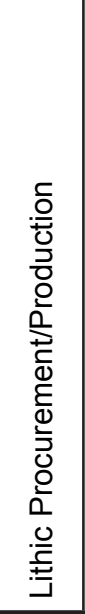 & 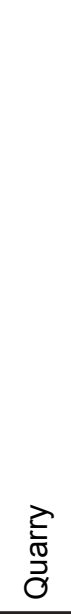 & 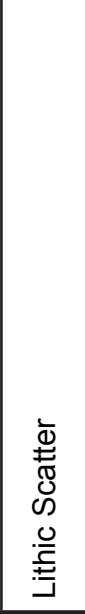 & $\begin{array}{l}\overline{\overline{0}} \\
\overline{\bar{c}} \\
\overline{0}\end{array}$ & $\begin{array}{l}\frac{\infty}{0} \\
\frac{0}{0} \\
\frac{0}{0} \\
\frac{0}{0} \\
\frac{0}{0}\end{array}$ &  & 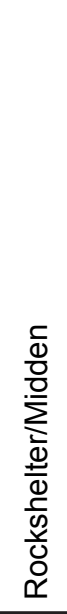 & $\begin{array}{l}\frac{0}{0} \\
\frac{0}{\underline{x}} \\
\dot{=}\end{array}$ & 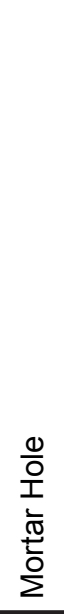 & 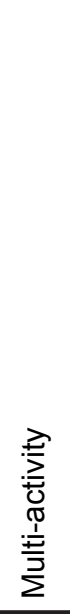 & $\begin{array}{l}\stackrel{\Phi}{ \pm} \\
\frac{\pi}{0} \\
\underline{0}\end{array}$ & 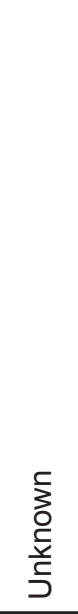 &  \\
\hline Hillslope & 12 & 2 & 29 & 2 & 15 & 1 & 1 & 1 & & 2 & & 5 & & 19 & 89 \\
\hline Hilltop & & 3 & 10 & 1 & 12 & & & 1 & & & & 3 & & 7 & 37 \\
\hline Hilltop/Slope & & & 2 & 2 & & & & & & & & & & & 4 \\
\hline Terrace & 50 & 36 & 14 & & 19 & & & 2 & 3 & & 2 & 9 & 1 & 18 & 154 \\
\hline Upland Drainage & 6 & 1 & & & 1 & & & & & & & & & & 8 \\
\hline Total & 68 & 42 & 55 & 5 & 47 & 1 & 1 & 4 & 3 & 2 & 2 & 17 & 1 & 44 & 292 \\
\hline Percentage & 23.3 & 14.4 & 18.8 & 1.7 & 16.1 & 0.3 & 0.3 & 1.4 & 1.0 & 0.7 & 0.7 & 5.8 & 0.3 & 15.1 & 100.0 \\
\hline
\end{tabular}


less numerous) on terraces $(\mathrm{n}=9)$ and hillslopes and hilltops $(\mathrm{n}=8)$ (Table 8.5).

Lithic procurement/production, quarries, and lithic scatters, all of which have similar compliments of artifacts and are formed through interrelated activities, occur in every topographic category and are most prevalent on hillslopes $(n=46)$, followed by terraces $(n=33)$, hilltops $(n=23)$, hilltop/slope $(n=4)$, and upland drainages $(n=1)$. If the lone incidence of an upland drainage lithic scatter is removed, the ratio of stone tool procurement/manufacturing sites located on hillslopes and hilltops (or both) to those on terraces is a little more than 2:1 (Table 8.5).

As Table 8.5 shows, the other eight site types have far fewer sites per type than those discussed above. In addition, they are located in far fewer topographic categories. Only one burial and one pictograph site have been recorded in the research area, each located on a hillslope, two mortar holes were found on terraces, two sinkholes were recorded on hillslopes, four rockshelters and three rockshelters with burned rock middens were found on hillslopes, hilltops, and terraces, one isolate was recorded on a terrace, and the remaining sites $(\mathrm{n}=44)$ contained no site type information. The presence of these types of archaeological sites adds significant diversity to the archaeological record, which would otherwise be solely informed by the preponderance of burned rock middens and lithic production sites. Unfortunately, the paucity of data available for these sites is such that little can be said about them, beyond recognizing their presence in the Upper Llano River watershed research area and singling them out as contributors to the archaeological record.

Alternatively, the comparative analysis of the patterns of site typology between open campsites, open campsites with burned rock middens, lithic procurement/production sites, quarries, and lithic scatters, is more promising. According to raw numbers of sites in different topographic settings, site 41KM225 is part of the largest group of site types (open campsite with a burned rock midden on a terrace), with 50 other sites of this type located in the research area. Only open campsites with burned rock scatters or hearths on terraces even come close to the number of burned rock midden sites on terraces. Based on this information, site $41 \mathrm{KM} 225$ is a very typical site type within the research area. Even if the site was found to have other burned rock features, such as hearths, outside of the tested area, it would still fall within a very common category.

Looking at a slightly broader context, terraces seem to be the most popular places as a whole to locate prehistoric archaeological sites (52.7 percent are found on terraces), particularly open campsites with burned rock middens (3:1 chance) and other open campsites (6:1 chance). Lithic procurement/production areas, quarries, and lithic scatters by contrast, are more likely to be found on upland areas, hilltops and hillslopes, than on terraces (ratio of 2:1), but are almost as common as any type of open campsite (107 sites vs. 110 sites, respectively).

What does this information say about cultural practices and the exploitation of available resources? Given the small number of specifically defined multiple activity archaeological sites (usually the combination of habitation and lithic procurement), and the statistically observable separation of habitation sites and lithic procurement/production sites in different topographic settings, it appears that prehistoric peoples in the Upper Llano River watershed research area, primarily in the Archaic period, were more apt to perform different activities in different places rather than combine several activities in one place. Lithic procurement and processing in particular appears to have been at least partially conducted in isolation to other activities. 
The analysis of such data sets may be used in the interpretation of foraging strategies and various other substantive research issues, such as the optimal foraging theory established by Winterhalder and Smith (1981) and Butzer's (1982) view of culture within a human ecosystem (i.e., a cultural landscape), and the foraging strategy models developed by Bettinger and Baumhoff (1982; traveler and processor model), Binford (1980; collector and forager model), and Woodburn (1982; delayed return versus immediate return economic model). For example, one suggested scenario is the testing of lithic material at the procurement site, shaping the cobbles into suitable cores or other travel-sized objects, and completing the tools at another location, perhaps where more time consuming hot rock cooking was taking place (Keller 1976). The data presented here would support that argument.

\section{Patterns in Tested Archaeological Sites}

Of the nine tested archaeological sites within the Upper Llano River watershed selected for study, seven of them are located on terraces overlooking medium-to-large watercourses. Archaeological sites in these areas locations would have a higher probability of preserving intact stratigraphic zones that would assist in discriminating between different occupation periods, and thus would be of great interest to archaeologists. The topographic location of each tested site is presented in Table 8.6.

All of the tested archaeological sites selected for comparative analysis are open campsites with some kind of burned rock feature or features. In addition, none of these sites have retained excellent or even good stratigraphic zones that could be used to identify discrete habitation surfaces or periods of occupation. The Honey Creek site (41MS32), arguably the most extensively researched site in the Upper Llano River watershed project area, could only be defined in terms of broad stratigraphic zones denoting the Paleoin-
dian/Early Archaic, the entire Middle and Late Archaic, and the Late Prehistoric (post-Archaic in the text) (Black et al. 1997:107). However, this is where the commonalities between sites end. Seven sites, including site 41KM225, have at least one burned rock midden. The other three have only hearths. No pattern in site size, depth of archaeological deposits, or periods of occupation could be connected with any of these open campsites. Nor did a comparison of topographic setting and site type reveal obvious patterns: open campsites with burned rocks middens are present in all three topographic locations, and the sites with only hearths are all located in the most common setting, i.e., terraces.

The archaeological investigations at each of these selected sites are very feature-focused, as are many other human habitation sites excavated throughout Texas and elsewhere. Unfortunately, this fact hinders the substantive comparative analysis between the tested sites elected for study and site 41KM225. Although a comparative analysis could be conducted between all of the features found, recorded, and excavated at the nine tested sites, none of that information could be compared to the burned rock midden at site $41 \mathrm{KM} 225$, since it was largely destroyed before it could be investigated. The areas that were excavated at site $41 \mathrm{KM} 225$ were on the

Table 8.6. Topography of Selected Tested Sites

\begin{tabular}{|c|c|c|}
\hline & Site & Topography \\
\hline 1 & $41 \mathrm{KM} 3$ & Terrace \\
\hline 2 & $41 \mathrm{KM} 61$ & Terrace \\
\hline 3 & $41 \mathrm{KM} 62$ & Terrace \\
\hline 4 & $41 \mathrm{KM} 90$ & Terrace \\
\hline 5 & $41 \mathrm{KM} 115$ & Terrace \\
\hline 6 & $41 \mathrm{KM} 126$ & Terrace \\
\hline 7 & $41 \mathrm{MS} 32$ & Terrace \\
\hline 8 & $41 \mathrm{SU} 20$ & Hillslope \\
\hline 9 & $41 \mathrm{SU} 18$ & Upland Drainage \\
\hline 10 & $41 \mathrm{KM} 225$ & Terrace \\
\hline
\end{tabular}




\section{8-18 Chapter 8}

margin of the burned rock midden, and no additional features were found within the areas investigated. Although site 41KM225 may have much in common with other open campsites with burned rock middens, the lack of directly comparative data (i.e., the burned rock midden peripheries), limits the extent to which those patterns can be applied to the current data set.

Despite a similar situation at the Honey Creek site, data recovery excavations went a step further than other tested archaeological sites in analyses of the artifact distributions of the excavated hand units. Although the artifact distributions described are only within excavation units containing features, the authors warned that the distributions may or may not be associated with the feature, since "overprinting" of numerous occupation surfaces may have obscured various relationships (Black et al. 1997:145-146, 156). Nevertheless, about 10 artifact clusters were observed and analyzed, which were all associated with the Late Prehistoric (post-Archaic) analytical units. There was also enough information to make some interpretations of gender-based activity areas in relation to the burned rock midden, based on the concentration of knapping debris and mano stations to the north (Black et al. 1997:166).

Unfortunately, a comparison between the artifact clusters at the Honey Creek site and the artifact distributions $41 \mathrm{KM} 225$ would be difficult, as the artifact patterning is attributed to the Late Prehistoric and site 41KM225 was occupied at a different time period, and the clusters are possibly associated with hearth features, which were not found at site 41KM225. In addition, the number of excavation units placed across the site at Honey Creek permitted the observation of horizontal spatial patterning. The rather limited number of excavation units at 41KM225, while revealing the dense concentration of artifacts at the top of the rise in TUs 2 and 4-6, was not sufficient to make any conclusions about artifact clustering and activity areas. However, the very fact that artifact clusters could be located surrounding a burned rock midden does lend some value to the exploration of midden peripheries, instead of centering solely on feature material.

\section{Conclusions}

The purpose of this chapter was to analyze and synthesize data from the Upper Llano River watershed to provide a wider historic context for the interpretation of site 41KM225. Chapter 5 described site 41KM225 in terms of the information that could be used to identify actual cultural activities at the site (a micro-scale intra-site discussion). The purpose of this chapter was to compare the data gathered from 41KM225 with other sites in order to observe patterns of chronology, landscape setting, and site typology that could provide clues on cultural practice and cultural change (a macro-scale inter-site analysis). This comparative analysis operated under the premise that prehistoric inhabitants of the Upper Llano River watershed research area were mobile hunter-gatherer groups that utilized a diversity of resources across the landscape. It was hoped that a comparative analysis would provide a realistic interpretation of settlement patterns, foraging strategies, or resource utilization, and perhaps determine 41KM225's place within that patterning. Given the information presented above, no clear relationship between the lower and higher elevations within the research area has been found, and the evidence has shown that the information derived from 41KM225 is only partially relevant to data from other sites.

However, the data set used in this analysis may simply be too small to show large scale patterning. Only 311 sites have been recorded in the Upper Llano River watershed research area (only 292 of which are prehistoric sites that have location information), and of those, only a handful have been investigated beyond their 
initial recordation. Future research should err on the side of caution when making any interpretations using such a small data set. This research suggests that similar large scale comparisons should be held off until a more robust data set is obtained. Hopefully the research above will provide some guidance in terms of what types of data to acquire in order to conduct broad analyses of cultural patterns and cultural change and address specific research issues. 



\section{Chapter 9}

\section{Summary, Conclusions, And Recommendations}

\section{Mindy Bonine}

\section{Site Summary}

Site 41KM225 was discovered by archaeologists from TxDOT during a survey of the area prior to the implementation of a road improvement project for FM 2169. More research was needed to determine if the site retained sufficient integrity and information potential to be eligible under Criterion D of the NRHP or for listing as an SAL, and SWCA was contracted by TxDOT ENV to conduct significance testing at site 41KM225. SWCA performed the investigations under Work Authorization No. 57520 SA007 and the final report was written under Work Authorization No. 57525 SA007. Texas Antiquities Permit 4183 was issued to Principal Investigator Kevin A. Miller, and Project Archaeologist Mindy Bonine supervised the daily fieldwork from July 24-28, 2006.

Site 41KM225 is located on both sides of FM 2169 , north of the second crossing on Johnson Creek. Portions of this site are eroding into the drainage ditches located adjacent to FM 2169. Cultural material was visible in both cutbanks and exposed surfaces on either side of FM 2169 within the 100-foot ROW. Evidence of a burned rock midden was observed in the eastern cutbank, but this portion of the site had been impacted by erosion and the construction of a cedar oil processing mill. As the possibility of more intact prehistoric subsurface cultural material was located on the west side of the roadway, the current investigation focused on investigating this portion of the site with test excavation units, as well as determining the overall site limits where possible. The testing investigations were limited to the portion of the site within the FM 2169 ROW.
SWCA gathered information from the site $41 \mathrm{KM} 225$ through $3.38 \mathrm{~m}^{3}$ of hand excavations; five shovel tests to determine site and feature limits; mapping and photographing of all excavations and topographical features; collection of all encountered artifacts from the excavations as well as surface utilized flakes, tools, and projectile points; and the collection of special samples including a charcoal sample from TU 1 , and a soil matrix sample from Feature 1 within ST 4.

Only one cultural component, AU 1, was documented during the testing excavations. AU 1 is defined as a mixed assemblage and associated cultural components within one gradually aggrading upland depositional unit, spanning from the ground surface to a subsurface gravel lens at $99.3 \mathrm{~m}$. Unfortunately, the compression of the stratigraphy and the bioturbation of the artifacts within the investigated areas have altered any discrete occupation surfaces, and the deposits defining AU 1 cannot be further refined into discrete temporal zones. AU 1 contains only one primary feature within the investigated area: Feature 1 is a small discrete cluster of burned limestone that was observed in the eastern cutbank of FM 2169. The feature appears to be an asymmetrical stack of limestone rocks. Feature 1 has been almost completely destroyed by the construction of FM 2169 and the cedar oil processing mill located on the east side of the ROW.

AU 1 dates to the Middle Archaic (5,700-5,500 B.P.) and the middle Late Archaic (3,300-2,300 B.P.), based on the presence of two projectile points, an Early Triangular-like point, and a Pedernales-like point. An untypeable point that bears some similarity to a Trans-Pecos Paisano point 
was also recovered from the surface. If this point were manufactured at the same time as the Paisano, it would date to the Transitional Archaic (200 B.C. to A.D. 600 , or around 2,150-1,350 B.P.). A charcoal sample recovered from the site and sent for radiocarbon assay revealed the disturbed nature of the assemblage within AU 1, with a Late Prehistoric date occupying a place below projectile points dating to the Archaic.

\section{Conclusions and Recommendations}

\section{DISCUSSION OF INTEGRITY}

The tested portions of the site are in an alluvial and colluvial setting that has resulted in the modest preservation of the archaeological record. Within the APE, the integrity of AU 1, dating to the Middle and middle Late Archaic, has been affected to a significant degree by the construction of FM 2169 and the adjacent cedar oil processing mill on private property to the east. At a minimum, the roadway construction and the subsequent erosion of the cutbanks has destroyed at least half, if not more, of Feature 1. Other hearth features may have been destroyed by the road construction as well, since no features were observed in the remaining intact portion of the site on the west side of the APE. The west side of the site appears to be comparatively intact; however, the deposits have compressed over time and experienced some bioturbation. The small intermittent drainage on the west side of the site has also affected its integrity. The uninvestigated portion of the site to the west may also contain intact cultural deposits, but its integrity has also been affected by the intermittent drainage. In addition, the same post depositional processes that have affected the investigated area in the APE have also likely impacted this area as well.

Where preserved, AU 1 contains limestone features, artifacts (mainly debitage with some tools), and very limited organics such as dateable carbon and ashy soils. The component is generally isolable from the earlier deposits by a well-defined gravel lens, but the Holocene deposits in which it is contained appear to be consistently compressed across all areas of the site. Utilizing diagnostic tools for interpretation, the deposits may represent the entire middle to late Holocene record within only a $20-30 \mathrm{~cm}$ zone. The implications of this for good preservation of organics, spatial patterning of features and artifacts, or isolable occupations is profound as thousands of years of time are potentially condensed into a thin zone. In combination with the significant recent impacts that have destroyed much of the site in the APE, the integrity of AU 1 is considered low. The site is not considered a good candidate for sub-divisions into distinct occupation surfaces. Further understanding of the integrity and age of AU 1 can only be gained through geomorphic study.

\section{SITE ELIGIBILITY}

Prior to conducting the testing, SWCA recommended that the eligibility of the site for NRHP nomination would be dependent upon levels of artifactual and contextual integrity, chronology, potential data yield, and preservation potential. The investigations, therefore, focused on two main issues: integrity and potential data yield. SWCA proposed that for the site to be found significant under Criterion D, the deposits must demonstrate good integrity and adequate data yield potential to address research questions that would contribute to the understanding of the regional prehistory. It was proposed that if the site has good integrity but few artifacts, no dateable materials, no features, and poor preservation of organics, it would not be able to contribute new or important information. Similarly, if the site were found to have abundant artifacts and materials but poor archaeological integrity, it would also not be considered significant. Site eligibility would hinge on its ability to address 
one or more explicit, non-trivial questions about prehistory.

Research Issue 1: Integrity of the ArChaeological Deposits. As mentioned above, the overall integrity of AU 1 is considered low, though some questions remain. The investigated portion of the site did contain just enough material to establish typological occupation dates as well as the potential for an absolute date (although the sample collected yielded questionable results). However, the single intact cultural deposit, the only cultural component that could be established at the site, cannot be subdivided into discrete occupation periods, which could be subject to specific, non-trivial, research questions. If the typological dates for the recovered projectile points are anywhere near the mark, the site is the result of several compressed occupation periods spanning the middle to late Holocene. These occupation surfaces could not be differentiated with the testing methodology employed, if they are indeed still present. Finally, preservation of non-stone artifacts appears to be very minimal as only one shell fragment was recovered from the excavations.

Research Issue 2: Potential Data Yield. The result of the testing excavations was the recovery of moderate amounts of lithic material, including bifaces, cores, debitage, scrapers, informal tools, and groundstone. Some modest amounts of burned limestone $(7.9 \mathrm{~kg}$ from the hand excavation units, or about $2.34 \mathrm{~g}$ for every other artifact recovered) were recorded in the subsurface investigations. Additionally, three projectile points were recovered, as well as one shell fragment and one charcoal sample. One discrete feature was observed (Feature 1), which consisted of what appears to be a midden approximately 15 $\mathrm{m}$ long consisting primarily of burned rocks in an ashy soil matrix approximately $36 \mathrm{~cm}$ thick. However, overall, the quantity and diversity of cultural material recovered from the site thus far is unimpressive, and does not constitute an assemblage of sufficient depth or breadth to answer important research questions. In other words, cultural material such as diagnostic and non-diagnostic tools were all recovered from the site, but not in sufficient quantities to make any meaningful interpretations about the artifact assemblage or cultural variables such as subsistence economy, organization, or other aspects of hunter-gatherer lifeways.

\section{RECOMMENDATIONS}

SWCA recommends that the portion of 41KM225 within the APE is not eligible for NRHP listing under Criterion D, 36 CFR 60.4. Furthermore, SWCA recommends that 41KM225 is not eligible for SAL designation under Criteria 1 and 2 of the Rules of Practice and Procedure for the Antiquities Code of Texas, 13 TAC 26.8. Data recovery excavations are not recommended for the site within the existing ROW.

To the east of the existing ROW on private land, the site has experienced erosion and construction impacts to such an extent that almost no deposits are intact. Any site deposits east of the fence would be too limited in size and content to warrant test excavations or be eligible for NRHP listing or SAL designation. To the west of the existing ROW on private land, the site undoubtedly extends for no more than $50 \mathrm{~m}$, based on topographical features. The eligibility of the portion of site $41 \mathrm{KM} 225$ west of the existing ROW is unknown, and therefore should be avoided or tested to make a definitive determination of significance. 



\section{Chapter 10}

\section{References Cited}

Ahler, S. A.

1989 Mass Analysis of Flaking Debris: Studying the Forest Rather than the Trees. In Alternative Approaches to Lithic Analysis, edited by D. Henry and G. Odell, pp. 85-119. Archaeological Papers of the American Anthropological Association, Number 1.

Andrefsky, W.

1998 Lithics: Macroscopic Approaches to Analysis. Cambridge University Press, Cambridge.

Arnn, J., and J. Abbott

2006 Archeological Impact Evaluation of FM 2169 at Johnson Creek. Environmental Affairs Division, Texas Department of Transportation, Austin.

Barnes, V. E.

1981 Geologic Atlas of Texas, Llano Sheet. The Bureau of Economic Geology, The University of Texas at Austin.

Bettinger, R. L., and M. A. Baumhoff

1982 The Numic Spread: Great Basin Cultures in Competition. American Antiquity 47(3):485-503.

Binford, L. R.

1983 In Pursuit of the Past: Decoding the Archaeological Record. Thames and Hudson, New York.
1980 Willow Smoke and Dogs'Tails: HunterGatherer Settlement Systems and Archaeological Site Formation. American Antiquity 45:4-20.

Black, S. L.

1989 Central Texas Plateau Prairie. In From the Gulf to the Rio Grande: Human Adaptation in Central, South, and Lower Pecos Texas, by Thomas R. Hester, Stephen L. Black, D. Gentry Steele, Ben W. Olive, Anne A. Fox, Karl J. Reinhard, and Leland C. Bement, pp. 17-38. Research Series No. 33. Arkansas Archeological Survey, Fayetteville.

Black, S. L., and A. J. McGraw

1985 The Panther Springs Creek Site: Cultural Change and Continuity within the Upper Salado Creek Watershed, SouthCentral Texas. Archeological Survey Report No. 100. Center for Archaeological Research, The University of Texas at San Antonio. 
Black, S. L., and D. G. Creel

1997 The Central Texas Burned Rock Midden Reconsidered. In Hot Rock Cooking on the Greater Edwards Plateau: Four Burned Rock Midden Sites in West Central Texas, Volume 1, by S. L. Black, L. W. Ellis, D. G. Creel, and G. T. Goode, pp. 269-306. Studies in Archeology 22. Texas Archeological Research Laboratory, The University of Texas at Austin. Archeology Studies Program, Report 2. Environmental Affairs Department, Texas Department of Transportation, Austin.

Black, S. L., and M. J. Quigg

2007 "Unstemmed Point Tradition," in Texas Beyond History, http://www. texasbeyondhistory.net/st-plains/pre history/images/unstemmed.html, accessed September 20, 2007.

Black, S. L., L. W. Ellis, D. G. Creel, and G. T. Goode

1997 Hot Rock Cooking on the Greater Edwards Plateau: Four Burned Rock Midden Sites in West Central Texas. Texas Archeological Research Laboratory, University of Texas at Austin. Studies in Archeology 22. Texas Department of Transportation Environmental Affairs Department. Archeology Studies Program, Report. Two Volumes.

Blair, W. F.

1950 The Biotic Provinces of Texas. The Texas Journal of Science 2(1):93-117.

Blum, E. L.

1982 Soil Survey of Kimble County, Texas. United States Department of Agriculture, Soil Conservation Service, Washington, D.C.
Bousman, C. B.

1992 Preliminary Oxygen-Isotope Evidence for Late Pleistocene-Early Holocene Climatic Change. Current Research in the Pleistocene 9:78-80.

1994 Central Texas Pollen Record: A Reinterpretation. Current Research in the Pleistocene 11:79-81.

1998 Paleoenvironmental Change in Central Texas: The Palynological Evidence. Plains Anthropologist (43)164:201219.

Burt, W. H., and R. P. Grossenheider 1976 Peterson Field Guides: Mammals. Houghton Mifflin Company, Boston and New York.

Butzer, K.

1982 Archaeology as Human Ecology. Cambridge University Press, Cambridge.

Campbell, R. B.

2003 Gone to Texas: A History of the Lone Star State. Oxford University Press. New York.

Camper, H. A.

1991 Pollen Analysis of Patschke Bog. Unpublished MS thesis, Department of Botany, Texas A\&M University, Bryan, Texas.

Cecil, P. F., and D. P. Greene

2004 The Handbook of Texas Online, s.v. Hays County. http:tsha.utexas.edu/ handbook/online/articles/view/HH/ hccl.html (accessed Friday May 14, 2004). 
Collins, M. B.

1968 A Note on the Broad Corner-Notched Projectile Points Used In Bison Hunting in Western Texas. The Bull Roarer 3(2) 13-14. The University of Texas Anthropology Society, Department of Anthropology, The University of Texas at Austin.

1990 The Archaeological Sequence at Kincaid Rockshelter, Uvalde County, Texas. Transactions of the Twenty-Fifth Regional Archeological Symposium for Southeastern New Mexico and Western Texas, pp. 25-34.

1995 Forty Years of Archeology in Central Texas. Bulletin of the Texas Archeological Society 66:361-400.

1998 Early Paleoindian Components. In Wilson-Leonard: An 11,000-Year Archeological Record of Hunter-Gatherers in Central Texas, Volume I, edited and assembled by Michael B. Collins, pp. 123-159. Studies in Archeology 31. Texas Archeological Research Laboratory, The University of Texas at Austin. Archeology Studies Program, Report 10. Environmental Affairs Division, Texas Department of Transportation.

2004 Archeology in Central Texas. In Prehistory of Texas, edited by Timothy K. Perttula, pp.101-126. Texas A\&M University Press. College Station, Texas.

Collins, M. B., B. Ellis, and C. Dodt-Ellis

1990 Excavations at the Camp Pearl Wheat Site (41KR243): An Early Archaic Campsite on Town Creek, Kerr County, Texas. Studies in Archeology 6. Texas Archeological Research Laboratory, The University of Texas at Austin.
Collins, M. B., C. B. Bousman, and T. K. Perttula

1993 Historic Context: Quaternary Environments and Archeology in Northeastern Texas. In Archeology in the Eastern Planning Region, Texas: A Planning Document, edited by N. A. Kenmotsu and T. K. Perttula, pp. 49-67. Cultural Resource Management Report 3. Department of Antiquities Protection, Texas Historical Commission, Austin.

Collins, M. B., J. Guy, and S. W. Dial

1998 The Archaic Period, 8800 to 1300 B.P. In Wilson-Leonard: An 11,000-Year Archeological Record of Hunter-Gatherers in Central Texas, Volume I, edited and assembled by M. B. Collins, pp. 211-270. Studies in Archeology 31. Texas Archeological Research Laboratory, University of Texas at Austin. Archeology Studies Program, Report 10. Environmental Affairs Division, Texas Department of Transportation.

Collins, M. B., T. R. Hester, and P. J. Hedrick

1992 Engraved Cobbles from the Gault Site, Central Texas. Current Research in the Pleistocene 9:3-4.

Collins, M. B., G. L. Evans, T. N. Campbell, M. C. Winans, and C. E. Mear

1989 Clovis Occupation at Kincaid Rockshelter, Texas. Current Research in the Pleistocene 6:3-4.

Conant, R., and J. T. Collins

1998 Peterson Field Guides: Reptiles and Amphibians. Eastern and Central North America. Houghton Mifflin Company, Boston and New York. 
Davis, W. B., and D. J. Schmidly

1994 The Mammals of Texas. University of Texas Press, Austin.

Dering, $\mathrm{P}$.

1999 Earth-Oven Plant Processing in Archaic Period Economies: An Example from a Semi-arid Savannah in South-Central North America. American Antiquity 64(4):659-674.

Dibble, D. S., and D. Lorrain

1968 Bonfire Shelter: A Stratified Bison Kill Site, Val Verde County, Texas. Miscellaneous Papers No. 1. Texas Memorial Museum, The University of Texas at Austin.

Doran, G. H.

1976 The Next Week Site. State Department of Highways and Public Transportation, Publications in Archaeology, Highway Design Division, Report No. 9.

Ferring, C. R.

1986 Rates of Fluvial Sedimentation: Implications for Archaeological Variability. Geoarchaeology 1:259-74.

Foster, W. C.

1995 Spanish Expeditions into Texas, 1689-1768. University of Texas Press, Austin.
Fredlund, G.

1998 Phytolith Analysis. In Wilson-Leonard, An 11,000-year Archeological Record of Hunter-Gatherers in Central Texas, Volume V: Special Studies, edited by M.B. Collins, pp. 1637-1651. Studies in Archeology 31. Texas Archeological Research Laboratory, The University of Texas at Austin. Archeology Studies Program, Report 10. Environmental Affairs Division, Texas Department of Transportation, Austin.

Goode, G. T.

1991 Late Prehistoric Burned Rock Middens in Central Texas. In The Burned Rock Middens of Texas: An Archeological Symposium, edited by Thomas R. Hester, pp. 71-93. Studies in Archeology 13. Texas Archeological Research Laboratory, The University of Texas at Austin.

Gould, F. W.

2002 Common Texas Grasses. Fourth Edition. Texas A\&M University Press, College Station.

Graham, R. W.

1987 Late Quaternary Fauna and Paleoenvironments of the Southwestern Plains of the United States. In Late Quaternary Mammalian Biogeography and Environments of the Great Plains and Prairies, edited by R. W. Graha, H. A. Semken Jr., and M. A. Graham, pp. 24-86. Scientific Papers Volume 22. Illinois State Museum, Springfield. 
Graham, R. W., and E. L. Lundelius, Jr.

1984 Coevolutionary Disequilibrium and Pleistocene Extinctions. In Quaternary Extinctions: A Prehistoric Revolution, edited by P. S. Martin and R. G. Klein, pp. 223-249. University of Arizona Press, Tucson.

Hatch, S. L., K. N. Gandhi, and L. E. Brown 1990. Checklist of the vascular plants of Texas. Texas Agricultural Experiment Station, Texas A \& M University, College Station.

Henderson, J.

1997 Archeological Testing of 41KM3, the Red Creek Site, a Burned Rock Midden Site, Kimble County, Texas. Prepared by the Texas Department of Transportation, on file at the Texas Historical Commission.

Henderson, J., and G. T. Goode

1991 Pavo Real: An Early Paleoindian Site in South-Central, Texas. Current Research in the Pleistocene 8:26-28.

Henry, D. O., C. V. Haynes, and B. Bradley

1976 Quantitative Variations in Flaked Stone Debitage. Plains Anthropologist 21:57-61.

Hester, T. R.

1971 Hafted Unifaces from Southwestern Coahuila, Mexico. The Kiva 36:3641.

1980 A Survey of Paleo-Indian Remains Along the Texas Coast. In Papers on the Archaeology of the Texas Coast, edited by L. Highley and T. R. Hester, pp. 1-22. Special Report 11. Center for Archaeological Research, The University of Texas at San Antonio.
1995 The Prehistory of South Texas. Bulletin of the Texas Archeological Society 66:427-459.

Hill, M. A.

2006 The Duck Lake Site and Implications for Late Archaic Copper Procurement and Production in the Southern Lake Superior Basin. Midcontinental Journal of Archaeology Fall 2006.

Hiscock, P.

2002 Quantifying the size of artefact assemblages. Journal of Archaeological Science 29:251-258.

Houk, B. A., and J. C. Lohse

1993 Archeological Investigations at the Mingo Site, Bandera County, Texas. Bulletin of the Texas Archeological Society 61:193-247.

Houk, B. A., C. B. Bousman, D. L. Nickels, and S. A. Tomka

1997a Analysis and Research Issues. In Phase II Archaeological Investigations at Lackland Air Force Base, San Antonio, Texas, by B. A. Houk and D. L. Nickels, pp. 103-146. Archaeological Survey Report, No. 264. Center for Archaeological Research, The University of Texas at San Antonio.

Houk, B. A., S. Tomka, B. Bousman, C. K. Chandler, B. Moses, M. Renner, and M. Lyons 1997b The Greenbelt Core: A Polyhedral Blade Core from San Antonio, Texas. Current Research in the Pleistocene 14:104-106.

Huebner, J. A.

1991 Late Prehistoric Bison Populations in Central and Southern Texas. Plains Anthropologist 36(137):343-358. 
Jelks, E.

1962 The Kyle Site: A Stratified Central Texas Aspect in Hill County, Texas. Archeology Series 5. Department of Anthropology, The University of Texas at Austin.

Johnson, L., Jr.

1987 A Plague of Phases: Recent Sociocultural Taxonomy in Texas Archeology. Bulletin of the Texas Archeological Society 57:1-26.

Johnson, L., Jr.

1995 Past Cultures and Climates at Jonas Terrace: 41ME29 of Medina County, Texas. Report No. 40. Office of the State Archeologist, Texas Historical Commission, Austin.

1994 The Life and Times of Toyah-Culture Folk: The Buckhollow Encampment, Site 41KM16 of Kimble County, Texas. Office of the State Archeologist Report 40. Texas Department of Transportation and Texas Historical Commission, Austin.

2000 Life and Death as seen at the Bessie Kruze Site (41WM13) on the Blackland Praire of Williamson County, Texas. Archeology Studies Program Report 22. Texas Department of Transportation and Texas Historical Commission, Austin.

Johnson, L., Jr., and G. T. Goode

1994 A New Try at Dating and Characterizing Holocene Climates, as Well as Archeological Periods, on the Eastern Edwards Plateau. Bulletin of the Texas Archeolgoical Society 65:1-51.
Johnson, L., Jr., D. A. Suhm, and C. D. Tunnell

1962 Salvage Archeology of Canyon Reservoir: The Wunderlich, Footbridge, and Oblate Sites. Bulletin No. 5. Texas Memorial Museum, The University of Texas at Austin.

Katz, P. R.

1987 Archaeological Mitigation at 41BX300, Salado Creek Watershed, South-Central Texas. Archaeological Survey Report No. 130. Center for Archaeological Research, The University of Texas at San Antonio.

Keller, J. E.

1976 The Stickleaf Site. State Department of Highways and Public Transportation, Publications in Archaeology, Highway Design Division, Report No. 8.

Kelley, J. C., and T. N. Campbell

1942 What are the Burnt Mounds of Texas? American Antiquity 7(3):319-322.

Kerr, A. C., and S. W. Dial

1998 Statistical Analysis of Unfluted Lanceolate and Early Bifurcate Stem Projectile Points. In Wilson-Leonard: An 11,000Year Archeological Record of HunterGatherers in Central Texas, Volume II, edited and assembled by Michael B. Collins, pp. 447-505. Studies in Archeology 31. Texas Archeological Research Laboratory, The University of Texas at Austin. Archeology Studies Program, Report 10. Environmental Affairs Division, Texas Department of Transportation. 
Kibler, K. W., and A. M. Scott

2000 Archaic Hunters and Gatherers of the Balcones Canyonlands: Data Recovery Excavations at the Cibolo Crossing Site (41BX377), Camp Bullis Military Reservation, Bexar County, Texas. Reports of Investigations No. 126. Prewitt and Associates, Inc., Austin.

Kleinbach, K., G. Mehalchick, J. T. Abbott, and J. M. Quigg

1995 Other Analyses. In NRHP Significance Testing of 57 Prehistoric Archeological Sites on Fort Hood, Texas, Volume II, edited by James T. Abbott and W. Nicholas Trierweiler, pp. 765-842. Archeological Resource Management Series, Research Report No. 34. United States Army Fort Hood.

Kutac, E. A., and S. C. Caran

1994 Birds and Other Wildlife of South Central Texas. University of Texas, Austin.

Luke, C. J.

1981 Test Excavations at Three Burned Rock Midden Sites in Sutton and Schleicher Counties, Texas. Texas State Department of Highways and Public Transportation, Publications in Archaeology, Highway Design Division, Report No. 19.

Lukowski, P. D.

1988 Archaeological Investigations at 41BX1, Bexar County, Texas. Archaeological Survey Report No. 135. Center for Archaeological Research, The University of Texas at San Antonio.
McGraw, A. J., and K. Hindes

1987 Chipped Stone and Adobe: A Cultural Resources Assessment of the Proposed Applewhite Reservoir, Bexar County, Texas. Archeological Survey Report No. 163. Center for Archeological Research, The University of Texas at San Antonio.

McKinney, W. W.

1981 Early Holocene Adaptations in Central and Southwestern Texas: The Problem of the Paleoindian-Archaic Transition. Bulletin of the Texas Archeology Society 52:91-120.

Mahoney, R. B., R. P. Mauldin, and S. A. Tomka

2002 Archeological Data Recovery Excavations along Becerra Creek (41WB556), Webb County, Texas. Center for Archaeological Research, Archaeological Survey Report, No. 321. University of Texas at San Antonio.

Meltzer, D. J., and M. R. Bever

1995 Paleoindians of Texas: An Update on the Texas Clovis Fluted Point Survey. Bulletin of the Texas Archeological Society 66:47-81.

Miller, M., and M. Faux (editors)

1997 The New York Public Library American History Desk Reference. The Stonesong Press, Inc. and the New York Public Library, N.Y.

Natural Heritage Policy Research Project

1978 Preserving Texas' Natural Heritage. Natural Heritage Policy Research Project, Lyndon B. Johnson School of Public Affairs, the University of Texas at Austin. Policy Research Project Report Number 31 . 
Nickels, D. L., and R. P. Mauldin

2001 An Archaeological Survey of Twin Buttes Reservoir, Tom Green County, Texas. Archaeological Survey Report, No. 300. Center for Archaeological Research, The University of Texas at San Antonio.

Niehaus, T. F., C. L. Ripper, and V. Savage

1984 Peterson Field Guides: Southwestern and Texas Wildflowers. Houghton Mifflin Company, Boston and New York.

Niering, W. A., and N. C. Olmstead

1990 National Audubon Society Field Guide to North American Wildflowers: Eastern Region. Eleventh Edition. Alfred A. Knopf, New York.

Nordt, L. C., T. W. Boutton, J. S. Jacob, and R. Mandel

1994 Late Quaternary Climates of Central Texas Based on the Stable Isotopic Composition of Organic Carbon. Program and Abstracts, 52 $2^{\text {nd }}$ Plains Conference, 65 th Annual Meeting of the Texas Archeological Society, Lubbock.

Petrides, G. A., and O. Petrides

1992 Peterson Field Guides: Western Trees. Houghton Mifflin Company, Boston and New York.

Prewitt, E. R.

1981 Cultural Chronology in Central Texas. Bulletin of the Texas Archaeological Society 52:65-90.

1985 From Circleville to Toyah: Comments on Central Texas Chronology. Bulletin of the Texas Archeological Society 54:201-238.
1995 Distributions of Typed Projectile Points in Texas. Bulletin of the Texas Archaeological Society 66:83-173.

Ricklis, R. A.

1992 The Spread of Late Prehistoric Bison Hunting Complex: Evidence from the South-Central Coastal Prairie of Texas. Plains Anthropologist 37(140):261273.

1994 Toyah Components: Evidence for Occupation in the Project Area during the Latter Part of the Late Prehistoric. In Archaic and Late Prehistoric Human Ecology in the Middle Onion Creek Valley, Hays County, Texas. Studies in Archeology 19. Texas Archeological Research Laboratory, The University of Texas at Austin.

Ricklis, R. A., M. D. Blum, and M. B. Collins 1991 Archaeological Testing at the Vera Daniels Site (41TV1364), Zilker Park, Austin, Texas. Studies in Archeology 12. Texas Archeological Research Laboratory. The University of Texas at Austin.

Robinson, D. G.

1994 Cultural Resource Investigations at the South Llano River State Park and Buck Wildlife Management Area, Kimble County, Texas. Texas Parks and Wildlife Department Cultural Resource Program, Austin, on file at the Texas Historical Commission. 
Robinson, R. L.

1982 Biosilica Analysis of Three Prehistoric Archaeological Sites in the Choke Canyon Reservoir, Live Oak County, Texas: Preliminary Summary of Climatic Implications. In Archaeological Investigations at Choke Canyon Reservoir, South Texas: The Phase I Findings, edited by G. D. Hall, S. L. Black, and C. Graves, pp. 597-610. Choke Canyon Series, No. 5. Center for Archaeological Research, The University of Texas at San Antonio.

Simpson, B. J.

1988 A Field Guide to Texas Trees. Texas Monthly Field Guide Series. Texas Monthly Press, Austin, Texas.

Sorrow, W. M.

1969 Archeological Investigations at the John Ischy Site: A Burned Rock Midden in Williamson County, Texas. Papers of the Texas Archeological Salvage Project No. 18. The University of Texas at Austin.

Spearing, D.

1991 Roadside Geology Series: Roadside Geology of Texas. Mountain Press Publishing Company. Missoula, MT.

Stahle, D. W., and J. E. Dunn

1982 An Analysis and Application of the Size Distribution of Waste Flakes from the Manufacturing of Bifacial Stone Tools. World Archaeology 14:84-97.
State Department of Highways and Public Transportation (SDHPT)

1987 Results of Testing and Research Design for Mitigation of Site 41MS32, a Burned Rock Midden Site in Mason County, Texas. State Department of Highways and Public Transportation Highway Design Division, Austin, Texas.

Stein, J., D. Binion, and R. Acciavati

2003 Field Guide to Native Oak Species of Eastern North America. United States Department of Agriculture Forest Service, Morgantown, WV.

Story, D. A.

1985 Adaptive Strategies of Archaic Cultures of the West Gulf Coastal Plain. In Prehistoric Food Production in North America, edited by R. I. Ford, pp. 19-56. Anthropological Papers 75. Museum of Anthropology, University of Michigan, Ann Arbor.

1990 Cultural History of the Native Americans. In The Archeology and Bioarcheology of the Gulf Coastal Plain, by Dee Ann Story, Janice A. Guy, Barbara A. Burnett, Martha Doty Freeman, Jerome C. Rose, D. Gentry Steele, Ben W. O1ive, and Karl J. Reinhard, pp. 163-366. Research Series No. 38. Arkansas Archeological Survey, Fayetteville.

Story, D. A., and V. M. Bryant

1966 A Preliminary Study of the Paleoecology of the Amistad Reservoir Area. Report of Research, National Science Foundation GS-667.

Suhm, D. A.

1960 A Review of Central Texas Archeology. Bulletin of the Texas Archeological Society 29:63-107. 
Suhm, D. A., and E. B. Jelks

1962 Handbook of Texas Archeology: Type Descriptions. Texas Archeological Society, Special Publications No. 1 and Texas Memorial Museum Bulletin No. 4, Austin, Texas.

Takac, P. R.

1991 Underwater Excavations at Spring Lake: A Paleoindian Site in Hays County, Texas. Current Research in the Pleistocene 8:46-48.

Taylor, R. (editor)

1996 The New Handbook of Texas in Six Volumes. The Texas State Historical Association, Austin.

Thompson, N.

2007 Handbook of Texas Online, s.v."Kimble County," http://www.tsha.utexas.edu/ handbook/online/articles/KK/hck7. html (accessed September 21, 2007).

Thoms, A. V., and R. D. Mandel

1992 The Richard Beene Site: A Deeply Stratified Paleoindian to Late Prehistoric Occupation in South-Central Texas. Current Research in the Pleistocene 9:42-44.

Thoms, A. V., D. D. Kuehn, B. W. Olive, J. E. Dockall, P. A. Clabaugh, and R. Mandel

1996 Early and Middle Holocene Occupations at the Richard Beene Site: The 1995 Southern Texas Archaeological Association Field School Project. $\mathrm{La}$ Tierra 23(4):8-36.
Toomey, R. S., III, and T. W. Stafford, Jr.

1994 Paleoenvironmental and Radiocarbon Study of the Deposits from Hall's Cave, Kerr County, Texas. Program and Abstracts, $52^{\text {nd }}$ Plains Conference, $65^{\text {th }}$ Annual Meeting of the Texas Archeological Society, Lubbock.

Toomey, R. S., III, M. D. Blum, and S. Valastro, Jr.

1993 Late Quaternary Climates and Environments of the Edwards Plateau, Texas. Global and Planetary Change 7:299-320.

Trigger, B. G.

1967 Settlement-its goals and promise. American Antiquity 32:149-60.

Turner, E. S., and T. R. Hester

1999 A Field Guide to Stone Artifacts of Texas Indians. Third Edition. Texas Monthly Field Guide Series. Gulf Publishing Company, Houston, Texas.

Wandsnider, L.

1997 The Roasted and the Boiled: Food Composition and Heat Treatment with Special Emphasis on Pit-Hearth Cooking. Journal of Anthropological Archaeology 16:1-48.

Weir, F. A.

1975 The Central Texas Archaic Reconsidered. Paper read at the Archaic Symposium at the Annual Meeting of the Texas Archeological Society, San Antonio, Texas.

1976 The Central Texas Archaic. Ph.D. Dissertation, Department of Anthropology, Washington State University, Pullman. 
Whitaker, J. O., Jr.

1989 National Audubon Society Field Guide to North American Mammals. Sixth Edition. Alfred A. Knopf, New York.

Willey, G. R., and P. Phillips

1958 Method and Theory in American Archaeology. University of Chicago Press, Chicago.

Wilson, E. W.

1930 Burnt Rock Mounds of Southwest Texas. Bulletin of the Texas Archaeological and Paleontological Society 2:59-63.

Winterhalder, B., and E. A. Smith (editors)

1981 Hunter-Gatherer Foraging Strategies. University of Chicago Press.

Woodburn, J.

1982 Egalitarian Societies. Man 17:431451.

Young, W. C.

1986 Archaeological Investigations in Eastern Kimble County, Texas. Prepared by the State Department of Highways and Public Transportation, Highway Design Division. Publications in Archaeology Report No. 30. 

Appendix A: Materials Recovered 

Table A.1. Materials Recovered From Surface

\begin{tabular}{|c|c|c|c|c|c|c|c|c|c|c|c|c|c|c|}
\hline \multirow[b]{2}{*}{ Context } & \multirow[b]{2}{*}{ Level } & \multicolumn{11}{|c|}{ Artifact Counts } & \multicolumn{2}{|c|}{ FCR } \\
\hline & & $\begin{array}{l}\text { Charcoal } \\
\text { Samples }\end{array}$ & $\begin{array}{c}\text { Soil } \\
\text { Samples }\end{array}$ & \begin{tabular}{|c|} 
Dart \\
Points
\end{tabular} & $\begin{array}{c}\text { Bifacial } \\
\text { Tools }\end{array}$ & $\begin{array}{l}\text { Flake } \\
\text { Tools }\end{array}$ & $\begin{array}{c}\text { Unifacial } \\
\text { Tools }\end{array}$ & $\begin{array}{l}\text { Ground- } \\
\text { stone }\end{array}$ & $\begin{array}{l}\text { Flake } \\
\text { Core }\end{array}$ & $\begin{array}{l}\text { Tested } \\
\text { Cobble }\end{array}$ & Debitage & Shell & \# & $\begin{array}{l}\text { Wt. } \\
\text { (kg) }\end{array}$ \\
\hline Cultural Deposit & Surface & & & 1 & 2 & 2 & & & & & & & & \\
\hline
\end{tabular}

Table A.2. Materials Recovered From TU 1

\begin{tabular}{|c|c|c|c|c|c|c|c|c|c|c|c|c|c|c|}
\hline \multirow[b]{2}{*}{ Context } & \multirow[b]{2}{*}{ Level } & \multicolumn{11}{|c|}{ Artifact Counts } & \multicolumn{2}{|c|}{ FCR } \\
\hline & & $\begin{array}{l}\text { Charcoal } \\
\text { Samples }\end{array}$ & $\begin{array}{c}\text { Soil } \\
\text { Samples }\end{array}$ & \begin{tabular}{|c|} 
Dart \\
Points
\end{tabular} & \begin{tabular}{|c|} 
Bifacial \\
Tools
\end{tabular} & $\begin{array}{l}\text { Flake } \\
\text { Tools }\end{array}$ & $\begin{array}{l}\text { Unifacial } \\
\text { Tools }\end{array}$ & $\begin{array}{l}\text { Ground- } \\
\text { stone }\end{array}$ & $\begin{array}{l}\text { Flake } \\
\text { Core }\end{array}$ & $\begin{array}{l}\text { Tested } \\
\text { Cobble }\end{array}$ & Debitage & Shell & \# & $\begin{array}{l}\text { Wt. } \\
\text { (kg) }\end{array}$ \\
\hline Cultural Deposit & 1 & & & & & & & & & & 8 & & 9 & 0.3 \\
\hline Cultural Deposit & 3 & & & & & & & & & & 3 & & & \\
\hline Cultural Deposit & 4 & & & & & & & & & & 8 & & 4 & 0.1 \\
\hline Cultural Deposit & 5 & 1 & & & & & & & & & 5 & & & \\
\hline
\end{tabular}

Table A.3. Materials Recovered From TU 2

\begin{tabular}{|c|c|c|c|c|c|c|c|c|c|c|c|c|c|c|}
\hline \multirow[b]{2}{*}{ Context } & \multirow[b]{2}{*}{ Level } & \multicolumn{11}{|c|}{ Artifact Counts } & \multicolumn{2}{|c|}{ FCR } \\
\hline & & $\begin{array}{l}\text { Charcoal } \\
\text { Samples }\end{array}$ & $\begin{array}{c}\text { Soil } \\
\text { Samples }\end{array}$ & $\begin{array}{c}\text { Dart } \\
\text { Points }\end{array}$ & $\begin{array}{c}\text { Bifacial } \\
\text { Tools }\end{array}$ & $\begin{array}{l}\text { Flake } \\
\text { Tools }\end{array}$ & $\begin{array}{c}\text { Unifacial } \\
\text { Tools }\end{array}$ & $\begin{array}{l}\text { Ground- } \\
\text { stone }\end{array}$ & $\begin{array}{l}\text { Flake } \\
\text { Core }\end{array}$ & $\begin{array}{l}\text { Tested } \\
\text { Cobble }\end{array}$ & Debitage & Shell & \# & $\begin{array}{l}\text { Wt. } \\
\text { (kg) }\end{array}$ \\
\hline Cultural Deposit & 1 & & & 1 & 2 & 4 & & & & & 87 & & 5 & 0.8 \\
\hline Cultural Deposit & 2 & & & & & & & & & & 47 & & & \\
\hline Cultural Deposit & 3 & & & & & 1 & & & & & 18 & & & \\
\hline Cultural Deposit & 4 & & & & & & & & & & 4 & & & \\
\hline Cultural Deposit & 5 & & & & & & & & 1 & & 1 & & & \\
\hline Cultural Deposit & 6 & & & & & & & & 1 & & 16 & & & \\
\hline Gravel Lens & 7 & & & & & & & & & & 17 & & & \\
\hline Below Gravel Lens & 8 & & & & & & & & & & 8 & & & \\
\hline Below Gravel Lens & 10 & & & & & & & & & & 2 & & & \\
\hline
\end{tabular}


Table A.4. Materials Recovered From TU 3

\begin{tabular}{|c|c|c|c|c|c|c|c|c|c|c|c|c|c|c|}
\hline \multirow[b]{2}{*}{ Context } & \multirow[b]{2}{*}{ Level } & \multicolumn{11}{|c|}{ Artifact Counts } & \multicolumn{2}{|c|}{ FCR } \\
\hline & & $\begin{array}{l}\text { Charcoal } \\
\text { Samples }\end{array}$ & $\begin{array}{c}\text { Soil } \\
\text { Samples }\end{array}$ & \begin{tabular}{|c|} 
Dart \\
Points
\end{tabular} & $\begin{array}{c}\text { Bifacial } \\
\text { Tools }\end{array}$ & $\begin{array}{l}\text { Flake } \\
\text { Tools }\end{array}$ & $\begin{array}{c}\text { Unifacial } \\
\text { Tools }\end{array}$ & $\begin{array}{l}\text { Ground- } \\
\text { stone }\end{array}$ & $\begin{array}{l}\text { Flake } \\
\text { Core }\end{array}$ & \begin{tabular}{|l|} 
Tested \\
Cobble
\end{tabular} & Debitage & Shell & \# & $\begin{array}{l}\text { Wt. } \\
\text { (kg) }\end{array}$ \\
\hline Cultural Deposit & 1 & & & & & & & & & & & & 2 & 2 \\
\hline Cultural Deposit & 2 & & & & & & & & & & 7 & & & \\
\hline Cultural Deposit & 3 & & & & & & & & & & 3 & & & \\
\hline Cultural Deposit & 4 & & & & & & & & & & 1 & & 2 & 1 \\
\hline Cultural Deposit & 5,6 & & & & & & & & & & 5 & & & \\
\hline
\end{tabular}

Table A.5. Materials Recovered From TU 4

\begin{tabular}{|c|c|c|c|c|c|c|c|c|c|c|c|c|c|c|}
\hline \multirow[b]{2}{*}{ Context } & \multirow[b]{2}{*}{ Level } & \multicolumn{11}{|c|}{ Artifact Counts } & \multicolumn{2}{|c|}{ FCR } \\
\hline & & $\begin{array}{l}\text { Charcoal } \\
\text { Samples }\end{array}$ & $\begin{array}{c}\text { Soil } \\
\text { Samples }\end{array}$ & $\begin{array}{c}\text { Dart } \\
\text { Points }\end{array}$ & $\begin{array}{c}\text { Bifacial } \\
\text { Tools }\end{array}$ & $\begin{array}{l}\text { Flake } \\
\text { Tools }\end{array}$ & $\begin{array}{c}\text { Unifacial } \\
\text { Tools }\end{array}$ & $\begin{array}{c}\text { Ground- } \\
\text { stone }\end{array}$ & $\begin{array}{l}\text { Flake } \\
\text { Core }\end{array}$ & $\begin{array}{l}\text { Tested } \\
\text { Cobble } \\
\end{array}$ & Debitage & Shell & $\#$ & $\begin{array}{l}\text { Wt. } \\
\text { (kg) }\end{array}$ \\
\hline Cultural Deposit & 1 & & & & & 2 & & & & & 25 & & 1 & 0.2 \\
\hline Cultural Deposit & 2 & & & & & & & & & & 25 & & 6 & 0.4 \\
\hline Cultural Deposit & 3 & & & & & & & & & & 9 & & & \\
\hline Cultural Deposit & 4 & & & & & & & & & & 10 & & & \\
\hline
\end{tabular}

Table A.6. Materials Recovered From TU 5

\begin{tabular}{|c|c|c|c|c|c|c|c|c|c|c|c|c|c|c|}
\hline \multirow[b]{2}{*}{ Context } & \multirow[b]{2}{*}{ Level } & \multicolumn{11}{|c|}{ Artifact Counts } & \multicolumn{2}{|c|}{ FCR } \\
\hline & & $\begin{array}{l}\text { Charcoal } \\
\text { Samples }\end{array}$ & $\begin{array}{c}\text { Soil } \\
\text { Samples }\end{array}$ & $\begin{array}{c}\text { Dart } \\
\text { Points }\end{array}$ & \begin{tabular}{|c|} 
Bifacial \\
Tools
\end{tabular} & $\begin{array}{l}\text { Flake } \\
\text { Tools }\end{array}$ & $\begin{array}{c}\text { Unifacial } \\
\text { Tools }\end{array}$ & $\begin{array}{c}\text { Ground- } \\
\text { stone }\end{array}$ & $\begin{array}{l}\text { Flake } \\
\text { Core }\end{array}$ & \begin{tabular}{|l|} 
Tested \\
Cobble
\end{tabular} & Debitage & Shell & \# & $\begin{array}{l}\text { Wt. } \\
\text { (kg) }\end{array}$ \\
\hline Cultural Deposit & 1 & & & & 1 & & & & & 1 & 21 & & 10 & 2.4 \\
\hline Cultural Deposit & 2 & & & & & & & & & & 13 & & & \\
\hline Cultural Deposit & 3 & & & & & & & & & & 3 & & & \\
\hline Cultural Deposit & 4 & & & & & & & & 1 & & 2 & & & \\
\hline
\end{tabular}


Table A.7. Materials Recovered From TU 6

\begin{tabular}{|c|c|c|c|c|c|c|c|c|c|c|c|c|c|c|}
\hline \multirow[b]{2}{*}{ Context } & \multirow[b]{2}{*}{ Level } & \multicolumn{11}{|c|}{ Artifact Counts } & \multicolumn{2}{|c|}{ FCR } \\
\hline & & $\begin{array}{l}\text { Charcoal } \\
\text { Samples }\end{array}$ & $\begin{array}{c}\text { Soil } \\
\text { Samples }\end{array}$ & \begin{tabular}{|c|} 
Dart \\
Points
\end{tabular} & $\begin{array}{c}\text { Bifacial } \\
\text { Tools }\end{array}$ & $\begin{array}{l}\text { Flake } \\
\text { Tools }\end{array}$ & \begin{tabular}{|c|} 
Unifacial \\
Tools
\end{tabular} & $\begin{array}{l}\text { Ground- } \\
\text { stone }\end{array}$ & $\begin{array}{l}\text { Flake } \\
\text { Core }\end{array}$ & \begin{tabular}{|l|} 
Tested \\
Cobble
\end{tabular} & Debitage & Shell & \# & $\begin{array}{l}\text { Wt. } \\
\text { (kg) }\end{array}$ \\
\hline Cultural Deposit & 1 & & & & & & & & & & 16 & & 1 & 0.1 \\
\hline Cultural Deposit & 2 & & & & 1 & & & & & & 7 & & & \\
\hline Cultural Deposit & 3 & & & & & & & 1 & & & 7 & & 2 & 0.3 \\
\hline
\end{tabular}

Table A.8. Materials Recovered From ST 1

\begin{tabular}{|c|c|c|c|c|c|c|c|c|c|c|c|c|c|c|}
\hline \multirow[b]{2}{*}{ Context } & \multirow[b]{2}{*}{ Level } & \multicolumn{11}{|c|}{ Artifact Counts } & \multicolumn{2}{|c|}{ FCR } \\
\hline & & $\begin{array}{l}\text { Charcoal } \\
\text { Samples }\end{array}$ & $\begin{array}{c}\text { Soil } \\
\text { Samples }\end{array}$ & \begin{tabular}{|c|} 
Dart \\
Points \\
\end{tabular} & $\begin{array}{c}\text { Bifacial } \\
\text { Tools }\end{array}$ & $\begin{array}{l}\text { Flake } \\
\text { Tools }\end{array}$ & $\begin{array}{c}\text { Unifacial } \\
\text { Tools }\end{array}$ & $\begin{array}{l}\text { Ground- } \\
\text { stone }\end{array}$ & $\begin{array}{l}\text { Flake } \\
\text { Core }\end{array}$ & $\begin{array}{l}\text { Tested } \\
\text { Cobble }\end{array}$ & Debitage & Shell & \# & $\begin{array}{l}\text { Wt. } \\
\text { (kg) }\end{array}$ \\
\hline Cultural Deposit & $0-15 \mathrm{cmbs}$ & & & & & & & & & & & & & \\
\hline
\end{tabular}

Table A.9. Materials Recovered From ST 2

\begin{tabular}{|c|c|c|c|c|c|c|c|c|c|c|c|c|c|c|}
\hline \multirow[b]{2}{*}{ Context } & \multirow[b]{2}{*}{ Level } & \multicolumn{11}{|c|}{ Artifact Counts } & \multicolumn{2}{|c|}{ FCR } \\
\hline & & $\begin{array}{l}\text { Charcoal } \\
\text { Samples }\end{array}$ & $\begin{array}{c}\text { Soil } \\
\text { Samples }\end{array}$ & $\begin{array}{l}\text { Dart } \\
\text { Points }\end{array}$ & $\begin{array}{c}\text { Bifacial } \\
\text { Tools }\end{array}$ & $\begin{array}{l}\text { Flake } \\
\text { Tools }\end{array}$ & $\begin{array}{c}\text { Unifacial } \\
\text { Tools }\end{array}$ & $\begin{array}{c}\text { Ground- } \\
\text { stone }\end{array}$ & $\begin{array}{l}\text { Flake } \\
\text { Core }\end{array}$ & $\begin{array}{l}\text { Tested } \\
\text { Cobble }\end{array}$ & Debitage & Shell & \# & $\begin{array}{l}\text { Wt. } \\
\text { (kg) }\end{array}$ \\
\hline Cultural Deposit & $15-20 \mathrm{cmbs}$ & & & & & & & & & & 3 & & & \\
\hline
\end{tabular}

Table A.10. Materials Recovered From ST 3

\begin{tabular}{|c|c|c|c|c|c|c|c|c|c|c|c|c|c|c|}
\hline \multirow[b]{2}{*}{ Context } & \multirow[b]{2}{*}{ Level } & \multicolumn{11}{|c|}{ Artifact Counts } & \multicolumn{2}{|c|}{ FCR } \\
\hline & & $\begin{array}{l}\text { Charcoal } \\
\text { Samples }\end{array}$ & $\begin{array}{c}\text { Soil } \\
\text { Samples }\end{array}$ & \begin{tabular}{|c|} 
Dart \\
Points
\end{tabular} & $\begin{array}{c}\text { Bifacial } \\
\text { Tools }\end{array}$ & $\begin{array}{l}\text { Flake } \\
\text { Tools }\end{array}$ & $\begin{array}{c}\text { Unifacial } \\
\text { Tools }\end{array}$ & $\begin{array}{l}\text { Ground- } \\
\text { stone }\end{array}$ & $\begin{array}{l}\text { Flake } \\
\text { Core }\end{array}$ & $\begin{array}{l}\text { Tested } \\
\text { Cobble }\end{array}$ & Debitage & Shell & \# & $\begin{array}{l}\text { Wt. } \\
\text { (kg) }\end{array}$ \\
\hline Cultural Deposit & $20-40 \mathrm{cmbs}$ & & & & & & 1 & & & & 4 & & 1 & \\
\hline
\end{tabular}


Table A.11. Materials Recovered From ST 4

\begin{tabular}{|c|c|c|c|c|c|c|c|c|c|c|c|c|c|c|}
\hline \multirow[b]{2}{*}{ Context } & \multirow[b]{2}{*}{ Level } & \multicolumn{11}{|c|}{ Artifact Counts } & \multicolumn{2}{|c|}{ FCR } \\
\hline & & $\begin{array}{l}\text { Charcoal } \\
\text { Samples }\end{array}$ & $\begin{array}{c}\text { Soil } \\
\text { Samples }\end{array}$ & $\begin{array}{c}\text { Dart } \\
\text { Points }\end{array}$ & \begin{tabular}{|c|} 
Bifacial \\
Tools
\end{tabular} & $\begin{array}{l}\text { Flake } \\
\text { Tools }\end{array}$ & $\begin{array}{c}\text { Unifacial } \\
\text { Tools }\end{array}$ & $\begin{array}{l}\text { Ground- } \\
\text { stone }\end{array}$ & $\begin{array}{c}\text { Flake } \\
\text { Core }\end{array}$ & $\begin{array}{l}\text { Tested } \\
\text { Cobble }\end{array}$ & Debitage & Shell & \# & $\begin{array}{l}\text { Wt. } \\
\text { (kg) }\end{array}$ \\
\hline Cultural Deposit & $0-20 \mathrm{cmbs}$ & & & & & & & & & & 1 & & $100+$ & \\
\hline Cultural Deposit & $20-40 \mathrm{cmbs}$ & & 1 & & & & & & & & 7 & & $125+$ & \\
\hline Cultural Deposit & $40-44 \mathrm{cmbs}$ & & & & & & & & & & 3 & & $30+$ & \\
\hline
\end{tabular}

Table A.12. Materials Recovered From ST 5

\begin{tabular}{|c|c|c|c|c|c|c|c|c|c|c|c|c|c|c|}
\hline \multirow[b]{2}{*}{ Context } & \multirow[b]{2}{*}{ Level } & \multicolumn{11}{|c|}{ Artifact Counts } & \multicolumn{2}{|c|}{ FCR } \\
\hline & & $\begin{array}{l}\text { Charcoal } \\
\text { Samples }\end{array}$ & $\begin{array}{c}\text { Soil } \\
\text { Samples }\end{array}$ & \begin{tabular}{|c|} 
Dart \\
Points
\end{tabular} & $\begin{array}{c}\text { Bifacial } \\
\text { Tools }\end{array}$ & $\begin{array}{l}\text { Flake } \\
\text { Tools }\end{array}$ & $\begin{array}{c}\text { Unifacial } \\
\text { Tools }\end{array}$ & $\begin{array}{l}\text { Ground- } \\
\text { stone }\end{array}$ & $\begin{array}{l}\text { Flake } \\
\text { Core }\end{array}$ & $\begin{array}{l}\text { Tested } \\
\text { Cobble }\end{array}$ & Debitage & Shell & \# & $\begin{array}{l}\text { Wt. } \\
\text { (kg) }\end{array}$ \\
\hline Cultural Deposit & $10-30 \mathrm{cmbs}$ & & & & & & & & & & & & $15+$ & \\
\hline Cultural Deposit & $30-50 \mathrm{cmbs}$ & & & & & & & & & & & & $20+$ & \\
\hline
\end{tabular}


Appendix B: Radiocarbon Results 



\begin{tabular}{|c|c|c|c|}
\hline Sample Data & $\begin{array}{c}\text { Measured } \\
\text { Radiocarbon Age }\end{array}$ & $\begin{array}{c}13 \mathrm{C} / 12 \mathrm{C} \\
\text { Ratio }\end{array}$ & $\begin{array}{c}\text { Conventional } \\
\text { Radiocarbon Age }\left(^{*}\right)\end{array}$ \\
\hline $\begin{array}{l}\text { Beta - } 230019 \\
\text { SAMPLE : 41KM225 } 43 \\
\text { ANALYSIS : AMS-Standard c } \\
\text { MATERIAL/PRETREATMEI } \\
2 \text { SIGMA CALIBRATION : }\end{array}$ & $\begin{array}{l}840 \text { +/- } 40 \mathrm{BP} \\
1160 \text { to } 1270 \text { (Cal BP }\end{array}$ & -26.3 o/oo & $820+/-40 \mathrm{BP}$ \\
\hline
\end{tabular}




\section{CALIBRATION OF RADIOCARBON AGE TO CALENDAR YEARS}

(Variables: C $13 /$ C $12=-26.3: 1$ ab. mult=1)

Laboratory number: Beta-230019

Conventional radiocarbon age: $820 \pm 40$ BP

2 Sigma calibrated result: C al AD 1160 to 1270 (C al BP 790 to 68 0) (95\% probability)

Intercept data

Intercept of radiocarb on age

w ith calibration curve: Cal AD 1220 (Cal B P 730)

1 Sigma calibrated result: Cal AD 1200 to 1260 (Cal BP 750 to 690)

(68\% probability)

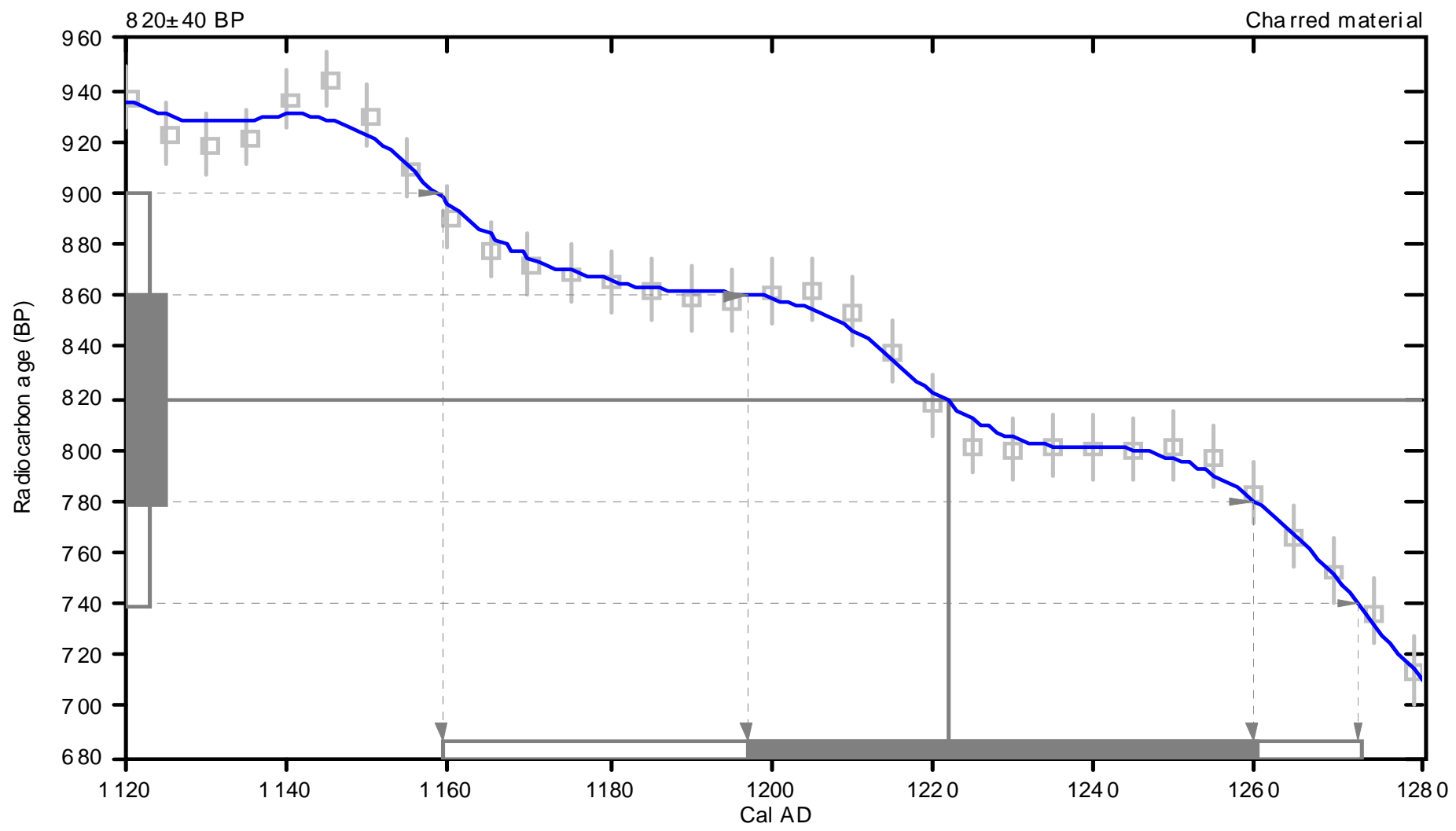

References:

Datab as e used INTC ALO 4

Ca lib ratio $n$ Da ta ba se

IN TC AL 04 Ra dioca rb on A ge Ca lib ra tion

IntC al04: Calibration Iss ue of Radiocarbon (Volume 4 6, nr 3, 2004 ).

Math ematics

A S implified A pproach to Ca librating C14 Dates

Ta Ima, A. S., Vo gel, J. C., 1993 , Radiocarbon 35 (2), p31 7-3 22 
Appendix C: Specimen Inventory 

Table C.1. Specimen Inventory for Site 41KM225

\begin{tabular}{|c|c|c|c|c|c|c|c|c|c|c|c|c|c|c|c|c|c|c|c|c|c|c|c|c|c|c|c|c|}
\hline Bag & Lot\# & Bag \# & Ftr. \# & SS \# & FS\# & ST \# & Shot\# & Unit & Level & \begin{tabular}{|c|} 
Top Elev. \\
$(\mathrm{m})$
\end{tabular} & \begin{tabular}{|c|} 
Bottom \\
Elev. $(\mathrm{m})$ \\
\end{tabular} & \begin{tabular}{|c|} 
Begin \\
Depth \\
\end{tabular} & \begin{tabular}{|c|}
$\begin{array}{c}\text { Elevation } \\
\text { Range }\end{array}$ \\
\end{tabular} & $\begin{array}{c}\text { End } \\
\text { Depth* }\end{array}$ & \begin{tabular}{|l|} 
Artifact \\
Category \\
\end{tabular} & Artifact Type & \begin{tabular}{|l} 
Artifact Description \\
\end{tabular} & $\#$ & \begin{tabular}{|c|} 
Weight \\
(g)
\end{tabular} & $\begin{array}{l}0-5 \mathrm{~cm} \\
\text { FCR\# } \\
\end{array}$ & $\begin{array}{c}0-5 \mathrm{~cm} \\
\text { FCR (kg) } \\
\end{array}$ & \begin{tabular}{|c|}
$5-10 \mathrm{~cm}$ \\
FCR\# \\
\end{tabular} & $\begin{array}{l}5-10 \mathrm{~cm} \\
F(\mathrm{CR}(\mathrm{kg}) \\
\end{array}$ & $\begin{array}{c}10-15 \mathrm{~cm} \\
\text { FCR \# }\end{array}$ & $\begin{array}{l}10-15 \mathrm{~cm} \\
\text { FCR (kg) } \\
\end{array}$ & Date & Initials & Comments \\
\hline 1 & 1 & 1 & . & & 1 & & 5 & & . & \begin{tabular}{|l|} 
Surface \\
\end{tabular} & Surface & Surface & - & Surface & Lithic & Projectile Point & Indeterminate & 1 & 3.6 & - & - & 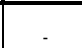 & . & - & . & \begin{tabular}{|l|l|} 
& $7 / 24 / 06$ \\
\end{tabular} & MRC & $\begin{array}{l}\text { Heavily reworked- } \\
\text { undiagnostic, Paisano-like }\end{array}$ \\
\hline 2 & 2 & 2 & - & - & 2 & - & 6 & - & - & \begin{tabular}{|l|l|} 
Surface \\
\end{tabular} & \begin{tabular}{|l|} 
Surface \\
\end{tabular} & Surface & - & Surface & Lithic & Formal Tool & Biface & 1 & \begin{tabular}{|l|}
152.9 \\
\end{tabular} & - & - & - & - & - & - & $7 / 24 / 106$ & MRC & \\
\hline 4 & 3 & 3 & . & & 3 & & 7 & & - & \begin{tabular}{|l|} 
Surface \\
\end{tabular} & Surface & Surface & - & Surface & Lithic & Formal Tool & Scraper & 1 & 16.5 & - & - & - & - & - & - & \begin{tabular}{|l|l|}
$7 / 24 / 06$ \\
\end{tabular} & MRC & $\begin{array}{l}\text { Indeterminate - bifacially } \\
\text { worked marginal tool }\end{array}$ \\
\hline 2 & 4 & 4 & - & - & 4 & 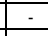 & 8 & - & - & \begin{tabular}{|l|} 
Surface \\
\end{tabular} & \begin{tabular}{|l|} 
Surface \\
\end{tabular} & \begin{tabular}{|l|} 
Surface \\
\end{tabular} & - & \begin{tabular}{|l|l|} 
Surface \\
\end{tabular} & Lithic & Formal Tool & Biface & 1 & \begin{tabular}{|l|}
207.6 \\
\end{tabular} & - & - & - & - & - & - & $7 / 24106$ & MRC & Crude biface \\
\hline 3 & 5 & 5 & - & - & 5 & - & 9 & - & - & \begin{tabular}{|l|l|} 
Surface \\
\end{tabular} & \begin{tabular}{|l|} 
Surface \\
\end{tabular} & Surface & & Surface & Lithic & Informal Tool & \begin{tabular}{|l|} 
Retouched Flake \\
\end{tabular} & 1 & 30 & & - & & - & & & $7 / 24 / 106$ & MRC & \\
\hline 4 & 6 & 7 & - & - & - & - & - & 1 & 1 & \begin{tabular}{ll|}
99.91 \\
\end{tabular} & 99.8 & 9 & $99.8+$ & 20 & Lithic & Debitage & Flaking Shatter & 3 & 0.9 & . & - & - & - & - & - & \begin{tabular}{|l|l|l|l|l|} 
\\
\end{tabular} & RAB/MRC & \\
\hline 4 & 6.1 & 7 & - & - & - & - & - & 1 & 1 & 99.91 & 99.8 & 9 & $99.8+$ & 20 & Lithic & Debitage & Broken Flakes & 5 & 5.5 & - & - & - & - & - & - & $7 / 25 / 06$ & RAB/MRC & \\
\hline 4 & 7 & 10 & - & - & - & - & - & 1 & 2 & $\begin{array}{ll}99.8 \\
\end{array}$ & 99.7 & 20 & \begin{tabular}{|l|}
$99.8-99.7$ \\
\end{tabular} & 30 & Lithic & Debitage & Flaking Shatter & 2 & 4.6 & - & - & - & - & - & - & $7 / 25 / 06$ & RAB/MRC & \\
\hline 4 & 7.1 & 10 & - & - & - & - & - & 1 & 2 & 99.8 & 99.7 & 20 & \begin{tabular}{|l|l|}
$99.8-99.7$ \\
\end{tabular} & 30 & Lithic & Debitage & Broken Flakes & 2 & 5.7 & 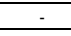 & - & 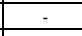 & - & - & 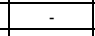 & $7 / 25 / 106$ & RAB/MRC & \\
\hline 1 & 8 & 10 & - & & - & - & - & 1 & 2 & *99.8 & *99.7 & $* 20$ & \begin{tabular}{|l|}
$99.8-99.7$ \\
\end{tabular} & $\star 30$ & Lithic & Projectile Point & Early Triangular & 1 & 6 & . & - & - & - & - & - & 7/25/106 & RAB/MRC & \begin{tabular}{|} 
*Point Provinience N68 E34 \\
99.77 - slight breaks along \\
basal corners and distal tip
\end{tabular} \\
\hline 4 & 9 & 15 & - & - & - & - & - & 1 & 3 & 99.7 & 99.6 & 30 & \begin{tabular}{|l|l|}
$99.7-99.6$ \\
\end{tabular} & 40 & Lithic & Debitage & Flaking Shatter & 2 & \begin{tabular}{|l|l|}
1.4 \\
\end{tabular} & - & - & - & - & - & - & $7 / 25106$ & RAB/MRC & \\
\hline 4 & 9.1 & 15 & - & & - & - & - & 1 & 3 & 99.7 & 99.6 & 30 & \begin{tabular}{|c|}
$99.7-99.6$ \\
\end{tabular} & 40 & \begin{tabular}{|l} 
Lithic \\
\end{tabular} & Debitage & Broken Flakes & 1 & \begin{tabular}{|l|l}
0.2 \\
\end{tabular} & $x_{2}$ & - & - & - & - & - & $7 / 25 / 106$ & RAB/MRC & \\
\hline 4 & 10 & 17 & - & - & - & - & - & 1 & 4 & 99.6 & 99.5 & 40 & $99.6-99.5$ & 50 & Lithic & Debitage & Flaking Shatter & 3 & \begin{tabular}{|l|l|}
2.7 \\
\end{tabular} & - & - & - & - & - & - & $7 / 25 / 06$ & RAB/MRC & \\
\hline 4 & \begin{tabular}{|l|}
10.1 \\
\end{tabular} & 17 & - & - & - & 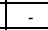 & - & 1 & 4 & 99.6 & 99.5 & 40 & $99.6-99.5$ & 50 & Lithic & Debitage & Broken Flakes & 3 & 2.4 & 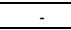 & - & - & - & - & 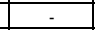 & $7 / 25106$ & RAB/MRC & \\
\hline 3 & \begin{tabular}{|l|}
10.2 \\
\end{tabular} & 17 & - & - & - & - & - & 1 & 4 & 99.6 & 99.5 & 40 & $99.6-99.5$ & 50 & Lithic & Debitage & Proximal Flakes & 2 & 0.7 & - & - & - & - & - & - & \begin{tabular}{|l|l|}
$7 / 25106$ \\
\end{tabular} & RAB/MRC & \\
\hline 4 & 11 & 20 & - & - & - & - & - & 1 & 5 & 99.5 & 99.4 & 50 & 99.5 - 99.4 & 60 & Lithic & Debitage & Flaking Shatter & 1 & 1.7 & - & - & - & - & - & - & \begin{tabular}{|l|l|}
$7 / 25 / 06$ \\
\end{tabular} & RAB/MRC & \\
\hline 4 & \begin{tabular}{|l|l|}
11.1 \\
\end{tabular} & 20 & - & - & - & - & - & 1 & 5 & 99.5 & 99.4 & 50 & $99.5-99.4$ & 60 & \begin{tabular}{|l} 
Lithic \\
\end{tabular} & Fire Cracked Chert & Thermal Shatter & 2 & \begin{tabular}{|l|l|}
0.9 \\
\end{tabular} & - & - & - & - & - & - & $7 / 25106$ & RAB/MRC & \\
\hline 3 & 11.2 & 20 & - & - & - & - & - & 1 & 5 & 99.5 & 99.4 & 50 & $99.5-99.4$ & 60 & Lithic & Debitage & \begin{tabular}{|l|l|l|} 
Comple Flakes \\
\end{tabular} & 2 & \begin{tabular}{|l|l}
9.7 \\
\end{tabular} & - & - & - & - & - & - & $7 / 25106$ & RAB/MRC & \\
\hline 4 & 12 & 23 & - & - & - & - & - & 1 & 6 & 99.4 & 99.3 & 60 & $99.4-99.3$ & 70 & Lithic & Debitage & Flaking Shatter & 2 & 1.4 & - & - & - & - & - & - & $7 / 25106$ & RAB/MRC & \\
\hline 4 & \begin{tabular}{|l|}
12.1 \\
\end{tabular} & 23 & - & - & - & - & - & 1 & 6 & 99.4 & 99.3 & 60 & \begin{tabular}{|c|}
$99.4-99.3$ \\
\end{tabular} & 70 & Lithic & Fire Cracked Chert & Thermal Shatter & 1 & 0.2 & - & - & - & - & - & $-5+2>$ & $\begin{array}{l}7 / 25106 \\
\end{array}$ & RAB/MRC & \\
\hline 4 & \begin{tabular}{|l|}
12.2 \\
\end{tabular} & 23 & - & - & - & - & - & 1 & 6 & 99.4 & 99.3 & 60 & \begin{tabular}{|l|}
$99.4-99.3$ \\
\end{tabular} & 70 & \begin{tabular}{|l|} 
Lithic \\
\end{tabular} & Debitage & Broken Flakes & 2 & 0.4 & 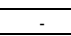 & - & - & - & - & - & $\begin{array}{l}71 / 25106 \\
\end{array}$ & RAB/MRC & \\
\hline 3 & \begin{tabular}{|l|}
12.3 \\
\end{tabular} & 23 & - & - & - & - & - & 1 & 6 & 99.4 & 99.3 & 60 & \begin{tabular}{|c|}
$99.4-99.3$ \\
\end{tabular} & 70 & Lithic & Debitage & \begin{tabular}{|l|l|l|} 
Complete Flakes \\
\end{tabular} & 2 & \begin{tabular}{|l}
2.1 \\
\end{tabular} & - & - & - & - & - & - & $7 / 25 / 06$ & RAB/MRC & \\
\hline 1 & 13 & 6 & - & & - & - & . & 2 & 1 & 100 & 99.8 & 0 & $99.8+$ & 20 & Lithic & Projectile Point & Pedernales & 1 & 7.1 & - & - & - & - & - & - & 7/24/106 & TN/CM & $\begin{array}{l}\begin{array}{l}\text { Stem fragment with one } \\
\text { missing shoulder }\end{array} \\
\end{array}$ \\
\hline 2 & \begin{tabular}{|l|}
13.1 \\
\end{tabular} & 6 & - & - & - & - & - & 2 & 1 & 100 & 99.8 & 0 & $99.8+$ & 20 & Lithic & Formal Tool & Biface & 1 & \begin{tabular}{|l}
50.9 \\
\end{tabular} & - & - & - & - & - & - & \begin{tabular}{|l|l|}
$7 / 24 / 06$ \\
\end{tabular} & TN/CM & Crude biface \\
\hline 2 & \begin{tabular}{|l|}
13.2 \\
\end{tabular} & 6 & - & - & - & - & - & 2 & 1 & 100 & 99.8 & 0 & $99.8+$ & 20 & \begin{tabular}{|l} 
Lithic \\
\end{tabular} & Formal Tool & Biface & 1 & \begin{tabular}{|l|}
9.1 \\
\end{tabular} & - & - & - & - & - & - & $7 / 24 / 06$ & TN/CM & \\
\hline 4 & 13.3 & 6 & - & - & - & - & - & 2 & 1 & 100 & 99.8 & 0 & $99.8+$ & 20 & Lithic & Formal Tool & Scraper & $=$ & 23.1 & - & - & - & - & - & - & $7 / 25106$ & TN/CM & \\
\hline 4 & \begin{tabular}{|l|l|}
13.4 \\
\end{tabular} & 6 & - & - & - & - & - & 2 & 1 & 100 & 99.8 & 0 & $99.8+$ & 20 & Lithic & Formal Tool & Scraper & 1 & \begin{tabular}{|l|}
32.1 \\
\end{tabular} & - & - & - & - & - & - & $7 / 25106$ & TN/CM & \\
\hline$n / a$ & 13.5 & $n / a$ & - & - & - & - & - & & & & & & & & & & & & & & - & - & - & - & $-5+2>$ & & & Lot \# not used \\
\hline 3 & \begin{tabular}{|l|}
13.6 \\
\end{tabular} & 6 & - & - & - & - & - & 2 & 1 & 100 & 99.8 & 0 & $99.8+$ & 20 & Lithic & Informal Tool & \begin{tabular}{|l|} 
Retouched Flake \\
\end{tabular} & 1 & \begin{tabular}{|l|l|}
15.6 \\
\end{tabular} & - & - & - & - & - & - & $7 / 24 / 06$ & TN/CM & \\
\hline 4 & \begin{tabular}{|l|}
13.7 \\
\end{tabular} & 6 & - & - & - & - & - & 2 & 1 & 100 & 99.8 & 0 & $99.8+$ & 20 & \begin{tabular}{|l|l|} 
Lithic \\
\end{tabular} & Debitage & Flaking Shatter & 15 & \begin{tabular}{|l|}
26.1 \\
\end{tabular} & - & - & 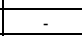 & - & - & - & $\begin{array}{l}7 / 242406 \\
\end{array}$ & TN/CM & \\
\hline 4 & \begin{tabular}{|l|}
13.8 \\
\end{tabular} & 6 & - & - & - & - & - & 2 & 1 & 100 & 99.8 & 0 & $99.8+$ & 20 & Lithic & Fire Cracked Chert & Thermal Shatter & 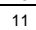 & 11 & 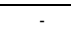 & 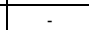 & - & - & - & - & $7 / 24 / 06$ & TN/CM & \\
\hline 4 & 13.9 & 6 & - & - & - & - & - & 2 & 1 & 100 & 99.8 & 0 & $99.8+$ & 20 & Lithic & Debitage & Broken Flakes & 20 & \begin{tabular}{|l|}
30.3 \\
\end{tabular} & - & - & - & - & - & - & $7 / 24 / 06$ & TN/CM & \\
\hline 3 & 13.10 & 6 & - & - & - & - & - & 2 & 1 & 100 & 99.8 & 0 & $99.8+$ & 20 & Lithic & Debitage & \begin{tabular}{|l|} 
Complete Flakes \\
\end{tabular} & 34 & \begin{tabular}{|l|}
324.2 \\
\end{tabular} & - & - & - & - & - & - & $7 / 25 / 06$ & TN/CM & \\
\hline 3 & 13.11 & 6 & - & & - & & - & 2 & 1 & 100 & 99.8 & 0 & $99.8+$ & 20 & Lithic & Debitage & Proximal Flakes & 7 & \begin{tabular}{|l|l|}
11.7 \\
\end{tabular} & & - & - & - & - & - & $7 / 24 / 06$ & TN/CM & \\
\hline \begin{tabular}{|l}
4 \\
\end{tabular} & \begin{tabular}{|l|l|}
14.14 \\
14
\end{tabular} & 8 & $\because$ & - & $\because$ & - & - & 2 & $\frac{1}{2}$ & 99.8 & 99.7 & 20 & \begin{tabular}{|l|}
$99.8-99.7$ \\
\end{tabular} & 30 & Lithic & Debitage & Flaking Shatter & 6 & \begin{tabular}{|l|}
16.1 \\
16.1 \\
\end{tabular} & & - & 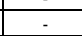 & $-5+20$ & - & -5 &  & TN/CM & \\
\hline 4 & \begin{tabular}{|l|}
14.1 \\
\end{tabular} & 8 & - & - & - & - & - & 2 & 2 & 99.8 & 99.7 & 20 & $99.8-99.7$ & 30 & Lithic & Fire Cracked Chert & Thermal Shatter & 5 & \begin{tabular}{|l|}
12.1 \\
\end{tabular} & -5 & - & - & - & - & -5 o & $7 / 25106$ & TN/CM & \\
\hline 4 & \begin{tabular}{|l|}
14.1 \\
\end{tabular} & 8 & - & - & - & - & - & 2 & 2 & 99.8 & 99.7 & 20 & \begin{tabular}{|l|l|}
$99.8-99.7$ \\
\end{tabular} & 30 & \begin{tabular}{|l} 
Lithic \\
\end{tabular} & Debitage & Broken Flakes & 10 & \begin{tabular}{|l|l|}
3.1 \\
\end{tabular} & - & - & - & - & - & - & $7 / 25106$ & TN/CM & \\
\hline 3 & \begin{tabular}{|l|}
14.3 \\
\end{tabular} & 8 & - & - & - & - & - & 2 & 2 & 99.8 & 99.7 & 20 & \begin{tabular}{|l|l|}
$99.8-99.7$ \\
\end{tabular} & 30 & Lithic & Debitage & \begin{tabular}{|l|l|l|} 
Comple Flakes \\
\end{tabular} & 21 & 10.3 & - & - & - & - & - & - & $7 / 25 / 06$ & TN/CM & \\
\hline 3 & \begin{tabular}{|l|}
14.4 \\
\end{tabular} & 8 & - & - & - & - & - & 2 & 2 & 99.8 & 99.7 & 20 & \begin{tabular}{|l|}
$99.8-99.7$ \\
\end{tabular} & 30 & Lithic & Debitage & $\begin{array}{l}\text { Proximal Flakes } \\
\end{array}$ & 5 & \begin{tabular}{|l|}
18.9 \\
\end{tabular} & - & - & - & - & - & - & $7 / 25106$ & TN/CM & \\
\hline 3 & 15 & 11 & - & - & - & - & - & 2 & 3 & 99.7 & 99.6 & 30 & \begin{tabular}{|c|}
$99.7-99.6$ \\
\end{tabular} & 40 & Lithic & Informal Tool & Utilized Flake & 1 & 7.8 & - & - & - & - & - & - & $7 / 25 / 06$ & TN/CM & \\
\hline \begin{tabular}{|l|l|}
4 & \\
\end{tabular} & \begin{tabular}{|c|}
15.1 \\
\end{tabular} & 11 & - & - & - & - & - & 2 & 3 & 99.7 & 99.6 & 30 & \begin{tabular}{|l|}
$99.7-99.6$ \\
\end{tabular} & 40 & Lithic & Fire Cracked Chert & Thermal Shatter & 5 & \begin{tabular}{|l|}
2.2 \\
\end{tabular} & - & - & - & - & - & - & $7 / 25106$ & TN/CM & \\
\hline 4 & \begin{tabular}{|l|}
15.2 \\
\end{tabular} & 11 & - & - & . & - & . & 2 & 3 & 99.7 & 99.6 & 30 & $99.7-99.6$ & 40 & Lithic & Debitage & Broken Flakes & 6 & 7.9 & & . & - & . & . & - & 7/25106 & TN/CM & \begin{tabular}{|} 
Changed from core to \\
angular debris - discarded
\end{tabular} \\
\hline 3 & \begin{tabular}{|l|}
15.3 \\
\end{tabular} & 11 & - & - & - & - & - & 2 & 3 & 99.7 & 99.6 & 30 & \begin{tabular}{|l|l|}
$99.7-99.6$ \\
\end{tabular} & 40 & \begin{tabular}{|l|l|l} 
Lithic \\
\end{tabular} & Debitage & \begin{tabular}{|c|c|c|c|c|c|} 
Flakes \\
\end{tabular} & 7 & \begin{tabular}{|l|}
18.1 \\
\end{tabular} & - & - & - & - & - & - & $7 / 25106$ & TN/CM & \\
\hline 4 & 16 & 13 & - & - & - & - & - & 2 & 4 & 99.6 & 99.5 & 40 & $99.6-99.5$ & 50 & Lithic & Debitage & Flaking Shatter & 2 & 4.2 & - & - & - & - & - & - & $7 / 25 / 06$ & TN/CM & Bifiacial \\
\hline 3 & \begin{tabular}{|l|}
16.1 \\
\end{tabular} & 13 & - & - & - & - & - & 2 & 4 & 99.6 & 99.5 & 40 & $99.6-99.5$ & 50 & Lithic & Debitage & \begin{tabular}{|l|l|l|} 
Comple Flakes \\
\end{tabular} & 2 & 3.4 & - & - & - & - & - & - & $7 / 25106$ & TN/CM & \\
\hline \begin{tabular}{|l|}
$n / a$ \\
\end{tabular} & \begin{tabular}{|l|l|}
17.1 \\
\end{tabular} & 16 & - & - & - & - & - & 2 & 5 & 99.5 & 99.4 & 50 & \begin{tabular}{|l|}
$99.5-99.4$ \\
\end{tabular} & 60 & Lithic & Angular Debris & \begin{tabular}{|l} 
Angular Debris \\
\end{tabular} & 1 & \begin{tabular}{|l|}
3.4 .2 \\
3.2
\end{tabular} & . & - & - & - & - & - & \begin{tabular}{|l|l|}
72125106 \\
\end{tabular} & TN/CM & Discarded \\
\hline 4 & \begin{tabular}{|l|}
17.1 \\
\end{tabular} & 16 & - & 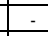 & - & 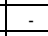 & - & 2 & 5 & 99.5 & 994 & 50 & 99.5 - 99.4 & 60 & Lithic & Debitage & Flaking Shatter & 1 & 63 & & - & - & - & - & - & $7 / 25 / 06$ & TN/CM & \\
\hline 2 & 18 & 21 & - & 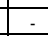 & - & - & - & 2 & 6 & 99.4 & 99.3 & 60 & \begin{tabular}{|l|l|}
$99.4-99.3$ \\
\end{tabular} & 70 & Lithic & Core & Core & 1 & \begin{tabular}{|l|l|}
113.5 \\
\end{tabular} & - & - & - & 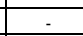 & - & - & $7 / 25106$ & TN/CM & \\
\hline 4 & \begin{tabular}{|l|}
18.1 \\
\end{tabular} & 21 & - & - & - & - & - & 2 & 6 & 99.4 & 99.3 & 60 & \begin{tabular}{|l|}
$99.4-99.3$ \\
\end{tabular} & 70 & Lithic & Debitage & Flaking Shatter & 8 & $\begin{array}{ll}3.1 \\
3.1\end{array}$ & - & - & - & - & - & - & $7 / 25106$ & TN/CM & \\
\hline 4 & \begin{tabular}{|l|}
18.2 \\
\end{tabular} & 21 & - & & - & -5 & - & 2 & 6 & 99.4 & 99.3 & 60 & \begin{tabular}{|l|}
$99.4-99.3$ \\
\end{tabular} & 70 & Lithic & \begin{tabular}{|l} 
Fire Cracked Chert \\
\end{tabular} & Thermal Shatter & 3 & \begin{tabular}{|l|}
1.3 \\
\end{tabular} & - & - & - & - & - & - & $7 / 26106$ & TN/CM & \begin{tabular}{|l|l|} 
Fossilized shell \\
\end{tabular} \\
\hline 4 & \begin{tabular}{|l|}
18.3 \\
\end{tabular} & 21 & - & 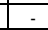 & - & - & - & 2 & 6 & 99.4 & 99.3 & 60 & \begin{tabular}{|l|}
$99.4-99.3$ \\
\end{tabular} & 70 & Lithic & Debitage & Broken Flakes & 6 & 6.2 & - & - & & - & - & & $\begin{array}{l}7 / 26 / 106 \\
\end{array}$ & TN/CM & \\
\hline 3 & \begin{tabular}{|l|l|}
18.4 & \\
\end{tabular} & 21 & - & 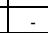 & - & 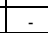 & 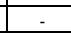 & 2 & 6 & 99.4 & 99.3 & 60 & \begin{tabular}{|l|}
$99.4-99.3$ \\
\end{tabular} & 70 & Lithic & & Complete Flakes & 5 & 5 & & - & & - & & - & $\begin{array}{l}7 / 26106 \\
\end{array}$ & TN/CM & \\
\hline 3 & \begin{tabular}{|l|}
18.5 \\
\end{tabular} & 21 & - & - & - & - & - & 2 & 6 & 99.4 & 99.3 & 60 & $99.4-99.3$ & 70 & Lithic & Debitage & $\begin{array}{l}\text { Proximal Flakes } \\
\end{array}$ & 2 & 1.5 & - & - & - & - & - & - & $\begin{array}{l}7126106 \\
\end{array}$ & TN/CM & \\
\hline
\end{tabular}


Table C.1. Specimen Inventory for Site 41KM225 (continued)

\begin{tabular}{|c|c|c|c|c|c|c|c|c|c|c|c|c|c|c|c|c|c|c|c|c|c|c|c|c|c|c|c|c|}
\hline Bag & Lot\# & Bag \# & Ftr. \# & ss \# & FS \# & ST \# & Shot \# & Unit & Level & \begin{tabular}{|c|} 
Top Elev. \\
$(\mathrm{m})$
\end{tabular} & \begin{tabular}{|c|} 
Bottom \\
Elev. $(\mathrm{m})$
\end{tabular} & $\begin{array}{c}\text { Begin } \\
\text { Depth } \\
\end{array}$ & $\begin{array}{c}\text { Elevation } \\
\text { Range }\end{array}$ & $\begin{array}{c}\text { End } \\
\text { Depth* }\end{array}$ & \begin{tabular}{|c|}
$\begin{array}{c}\text { Artifact } \\
\text { Category }\end{array}$ \\
\end{tabular} & Artifact Type & Artifact Description & $\#$ & \begin{tabular}{|} 
Weight \\
(g)
\end{tabular} & $\begin{array}{l}0.5 \mathrm{~cm} \\
\mathrm{FCR} \#\end{array}$ & $\begin{array}{c}0.5 \mathrm{~cm} \\
\operatorname{FCR}(\mathrm{kg}) \\
\end{array}$ & $\begin{array}{r}5-10 \mathrm{~cm} \\
\text { FCR \# }\end{array}$ & $\begin{array}{l}5-10 \mathrm{~cm} \\
\text { FCR }(\mathrm{kg}) \\
\end{array}$ & $\begin{array}{r}10.15 \mathrm{~cm} \\
\mathrm{~F} R \#\end{array}$ & $\begin{array}{l}10-15 \mathrm{~cm} \\
\text { FCR (kg) }\end{array}$ & Date & Initials & Comments \\
\hline$n / a$ & 19 & 22 & - & - & - & - & - & 2 & 7 & $\begin{array}{ll}99.3 \\
\end{array}$ & 99.2 & 70 & $99.3-99.2$ & 80 & Non-Lithic & Shell & Shell & 1 & 1.1 & - & - & - & - & - & - & $7 / 26 / 106$ & TN/CM & \\
\hline \begin{tabular}{|l|}
4 \\
\end{tabular} & \begin{tabular}{|l|l|}
19.1 \\
\end{tabular} & 22 & - & - & - & - & - & 2 & 7 & 99.3 & 99.2 & 70 & $99.3-99.2$ & 80 & Lithic & Debitage & Flaking Shatter & 7 & \begin{tabular}{|l|l}
11.2 \\
\end{tabular} & - & - & - & - & - & - & $7 / 261 / 06$ & TN/CM & \\
\hline 4 & \begin{tabular}{|l|l}
19.2 \\
\end{tabular} & 22 & - & - & - & - & - & 2 & 7 & 99.3 & 99.2 & 70 & $99.3-99.2$ & 80 & Lithic & Fire Cracked Chert & Thermal Shatter & 7 & 7.5 & - & - & - & - & - & - & $7 / 26 / 106$ & TN/CM & \\
\hline 4 & \begin{tabular}{|l|l}
19.3 \\
\end{tabular} & 22 & - & - & - & - & - & 2 & 7 & 99.3 & 99.2 & 70 & $99.3-99.2$ & 80 & Lithic & Debitage & Broken Flakes & 3 & 7.1 & - & - & - & - & - & - & $7 / 26 / 106$ & TN/CM & \\
\hline 4 & 20 & 25 & - & - & - & - & - & 2 & 8 & 99.2 & 99.1 & 80 & $99.2-99.1$ & 90 & Lithic & Fire Cracked Chert & Thermal Shatter & 1 & 0.3 & $\therefore$ & . & - & - & . & - & $7 / 24 / 06$ & $\mathrm{TN} / \mathrm{CM}$ & $\begin{array}{l}\text { End scraper - missing small } \\
\text { portion of distal end }\end{array}$ \\
\hline 4 & 20.1 & 25 & & & - &  & - & 2 & 8 & 99.2 & 99.1 & 80 & $99.2-99.1$ & 90 & \begin{tabular}{|l|} 
Lithic \\
\end{tabular} & Debitage & Broken Flakes & 4 & 2.7 & - & - & & - & - & & $7 / 24 / 106$ & TN/CM & $\begin{array}{l}\text { End and side scraper - } \\
\text { missing LLM and portion of } \\
\text { DM }\end{array}$ \\
\hline 3 & 20.2 & 25 & - & - & - & - & - & 2 & 8 & 99.2 & 99.1 & 80 & $99.2-99.1$ & 90 & Lithic & Debitage & \begin{tabular}{|c|c|c|c|c|} 
Comple Fles \\
\end{tabular} & 3 & \begin{tabular}{|l|}
37.2 \\
\end{tabular} &  & - & - & - & - & - & $7 / 24 / 06$ & TN/CM & \\
\hline 4 & 21 & 30 & - & 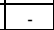 & - & 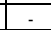 & - & 2 & 10 & 99 & 98.9 & 100 & $99.0-98.9$ & 110 & Lithic & Debitage & Broken Flakes & 2 & 1 & - & - & - & - & - & - & \begin{tabular}{|l|l|l|l|l|l} 
\\
\end{tabular} & TN/CM & Discarded in field \\
\hline 4 & 22 & 9 & - & - & - & - & - & 3 & 2 & 99.7 & 99.6 & 20 & $99.7-99.6$ & 30 & Lithic & Debitage & Flaking Shatter & 1 & 2.3 & - & - & - & - & - & - & $7 / 25 / 06$ & MRC & \\
\hline 4 & 22.1 & 9 & - & - & - & - & - & 3 & 2 & 99.7 & 99.6 & 20 & $99.7-99.6$ & 30 & Lithic & Debitage & Broken Flakes & 1 & 1 & . & - & - & - & - & - & $7 / 25106$ & MRC & \\
\hline 3 & 22.2 & 9 & - & - & - & - & - & 3 & 2 & 99.7 & 99.6 & 20 & $99.7-99.6$ & 30 & Lithic & Debitage & \begin{tabular}{|l|} 
Complete Flakes \\
\end{tabular} & 1 & 5.1 & - & - & - & - & - & - & $7 / 25 / 06$ & MRC & \\
\hline 3 & 22.3 & 9 & - & - & - & - & - & 3 & 2 & 99.7 & 99.6 & 20 & $99.7-99.6$ & 30 & Lithic & Debitage & Proximal Flakes & 4 & 2.6 & - & - & - & - & - & - & $7 / 25106$ & MRC & \\
\hline 4 & 23 & 12 & - & - & - & 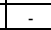 & - & 3 & 3 & 99.6 & 99.5 & 30 & $99.6-99.5$ & 40 & Lithic & Fire Cracked Chert & Thermal Shatter & 1 & 9.9 & - & - & 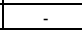 & - & - & 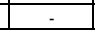 & $7 / 25106$ & MRC/MB & \\
\hline 4 & 23.1 & 12 & - & - & - & - & - & 3 & 3 & 99.6 & 99.5 & 30 & $99.6-99.5$ & 40 & Lithic & Debitage & Broken Flakes & 2 & \begin{tabular}{|l|l|}
16.9 \\
\end{tabular} & - & - & - & - & - & - & \begin{tabular}{|l|l|}
$7 / 25 / 06$ \\
\end{tabular} & MRC/MB & \\
\hline 4 & 24 & 14 & - & - & - & - & - & \begin{tabular}{|c|}
3 \\
\end{tabular} & 4 & 99.5 & 99.4 & 40 & $99.5-99.4$ & 50 & Lithic & Debitage & Flaking Shatter & 1 & 4.4 & - & - & - & - & - & - & 7/25106 & MRC/MB & \\
\hline 4 & 25 & 18 & - & - & - & - & - & 3 & 5,6 & 99.4 & 99.2 & 50 & $99.3-99.2$ & 70 & Lithic & Debitage & Broken Flakes & 2 & 8 & - & - & - & - & - & - & $7 / 25 / 06$ & MRC/MB & \\
\hline 3 & 25.1 & 18 & - & - & - & - & - & 3 & 5,6 & 99.4 & 99.2 & 50 & $99.3-99.2$ & 70 & Lithic & Debitage & \begin{tabular}{|l|l|l|} 
Comple Flakes \\
\end{tabular} & 3 & 1.3 & - & - & - & - & - & - & $7 / 25106$ & MRC/MB & \\
\hline 3 & 26 & 26 & - & - & - & - & - & \begin{tabular}{|l|}
4 \\
\end{tabular} & 1 & 99.9 & 99.8 & 10 & $99.8+$ & 20 & Lithic & Informal Tool & \begin{tabular}{|l} 
Retouched Flake \\
\end{tabular} & 1 & \begin{tabular}{|l|}
32.1 \\
\end{tabular} & - & - & - & - & - & - & $7 / 26106$ & MCC/RAB & \\
\hline \begin{tabular}{|l|}
4 \\
\end{tabular} & 26.1 & 26 & - & - & - & - & - & 4 & 1 & 99.9 & 99.8 & 10 & $99.8+$ & 20 & Lithic & $\begin{array}{l}\text { Formal Tool } \\
\end{array}$ & Scraper & 1 & 14 & - & - & - & - & - & - & $7 / 266106$ & MCC/RAB & End scraper \\
\hline 4 & 26.2 & 26 & - & - & - & - & - & \begin{tabular}{|l|l|}
4 \\
\end{tabular} & 1 & 99.9 & 99.8 & 10 & $99.8+$ & 20 & Lithic & Debitage & Flaking Shatter & 3 & 1.5 & - & - & - & - & - & - & \begin{tabular}{|l|l|}
$7 / 26 / 106$ \\
\end{tabular} & MCC/RAB & \\
\hline 4 & 26.3 & 26 & - & - & - & - & - & \begin{tabular}{|l|}
4 \\
\end{tabular} & 1 & 99.9 & 99.8 & 10 & $99.8+$ & 20 & Lithic & Fire Cracked Chert & Thermal Shatter & 4 & 4.7 & - & - & - & - & - & - & $7 / 26 / 106$ & MCC/RAB & \\
\hline 4 & 26.4 & 26 & - & - & - & - & - & 4 & 1 & 99.9 & 99.8 & 10 & $99.8+$ & 20 & Lithic & Debitage & Broken Flakes & 4 & 2.7 & - & - & - & - & - & - & $7 / 26106$ & MCCIRAB & \\
\hline 3 & 26.5 & 26 & - & - & - & - & - & \begin{tabular}{|l|}
4 \\
\end{tabular} & 1 & 99.9 & 99.8 & 10 & $99.8+$ & 20 & Lithic & Debitage & \begin{tabular}{|l|l|l|} 
Comple Flakes \\
\end{tabular} & 7 & \begin{tabular}{|l|l|}
13.4 \\
\end{tabular} & . & - & - & - & - & - & $7 / 26106$ & MCC/RAB & \\
\hline 3 & \begin{tabular}{|l|l|}
26.6 \\
\end{tabular} & 26 & - & - & - & - & - & 4 & 1 & 99.9 & 99.8 & 10 & $99.8+$ & 20 & Lithic & Debitage & Proximal Flakes & 7 & \begin{tabular}{ll|}
7.8 \\
\end{tabular} & - & - & - & - & - & - & $7 / 26106$ & MCC/RAB & \\
\hline 4 & 27 & 28 & - & - & - & - & - & \begin{tabular}{|l|}
4 \\
\end{tabular} & 2 & 99.8 & 99.7 & 20 & $99.8-99.7$ & 30 & Lithic & Debitage & Flaking Shatter & 7 & 4.2 & - & - & - & - & - & - & $7 / 26 / 106$ & MCC/RAB & \\
\hline 4 & 27.1 & 28 & - & - & - & - & - & \begin{tabular}{|l|l|}
4 & \\
\end{tabular} & 2 & 99.8 & 99.7 & 20 & $99.8-99.7$ & 30 & Lithic & Debitage & Broken Flakes & 8 & 20 & - & - & - & - & - & - & \begin{tabular}{|l|l|}
$7 / 26 / 106$ \\
\end{tabular} & MCC/RAB & \\
\hline 3 & 27.2 & 28 & - & - & - & - & - & \begin{tabular}{|l|l|}
4 \\
\end{tabular} & 2 & 99.8 & 99.7 & 20 & $99.8-99.7$ & 30 & Lithic & Debitage & \begin{tabular}{|l|l|l|l|} 
Comple Flaks \\
\end{tabular} & 7 & \begin{tabular}{|l|}
10.1 \\
\end{tabular} & - & - & - & - & - & - & $7 / 26106$ & MCCIRAB & \\
\hline 3 & \begin{tabular}{|l|l|}
27.3 \\
\end{tabular} & 28 & - & - & - & - & - & \begin{tabular}{|l|}
4 \\
\end{tabular} & 2 & 99.8 & 99.7 & 20 & $99.8-99.7$ & 30 & Lithic & Debitage & Proximal Flakes & 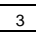 & \begin{tabular}{|l|l|}
0.8 & \\
\end{tabular} & - & - & - & - & - & - & $7 / 26106$ & MCC/RAB & \\
\hline 4 & \begin{tabular}{|l|}
28 \\
\end{tabular} & 32 & - & - & - & - & - & \begin{tabular}{|l|}
4 \\
\end{tabular} & 3 & 99.7 & 99.6 & 30 & $99.7-99.6$ & 40 & Lithic & Fire Cracked Chert & Thermal Shatter & 3 & 2 & - & - & - & - & - & - & $7 / 26106$ & MCC/RAB & \\
\hline 4 & 28.1 & 32 & - & - & - & - & - & 4 & 3 & 99.7 & 99.6 & 30 & $99.7-99.6$ & 40 & Lithic & Debitage & Broken Flakes & 6 & $\begin{array}{ll}3.6 \\
\end{array}$ & . & - & - & - & - & - & $7 / 26 / 106$ & MCC/RAB & \\
\hline 4 & 29 & 33 & - & - & - & - & - & 4 & 4 & 99.6 & 99.5 & 40 & $99.6-99.5$ & 50 & Lithic & Debitage & Flaking Shatter & 4 & \begin{tabular}{|l|}
71.1 \\
\end{tabular} & - & - & - & - & - & - & $7 / 27106$ & MCC/RAB & \\
\hline 4 & 29.1 & 33 & - & - & - & - & - & \begin{tabular}{|l|}
4 \\
\end{tabular} & 4 & 99.6 & 99.5 & 40 & $99.6-99.5$ & 50 & Lithic & Fire Cracked Chert & Thermal Shatter & 2 & 6.1 & - & - & - & - & - & - & \begin{tabular}{|l|l|}
$7 / 27106$ \\
\end{tabular} & MCC/RAB & \\
\hline 3 & 29.2 & 33 & - & - & - & - & - & \begin{tabular}{|l|l|}
4 & \\
\end{tabular} & 4 & 99.6 & 99.5 & 40 & $99.6-99.5$ & 50 & Lithic & Debitage & \begin{tabular}{|l|l|l|} 
Completakes \\
\end{tabular} & 4 & 6 & - & - & 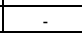 & - & - & - & $7 / 27106$ & MCC/RAB & \\
\hline 2 & 30 & 27 & - & - & - & - & - & 5 & 1 & 99.9 & 99.8 & 10 & $99.8+$ & 20 & Lithic & Formal Tool & \begin{tabular}{|l|} 
Biface \\
\end{tabular} & 1 & \begin{tabular}{|l|}
4.5 \\
\end{tabular} & - & - & - & - & - & - & $7 / 26106$ & MRC/MB & Indeterminate \\
\hline 2 & \begin{tabular}{|l|l|}
30.1 & \\
\end{tabular} & 27 & - & - & - & - & - & 5 & 1 & 99.9 & 99.8 & 10 & $99.8+$ & 20 & Lithic & Core & Tested Cobble & 1 & \begin{tabular}{|l|}
217.7 \\
\end{tabular} & - & - & - & - & - & - & $7 / 26 / 106$ & MRC/MB & \\
\hline 4 & \begin{tabular}{|l|}
30.2 \\
\end{tabular} & 27 & - & & - & - & - & \begin{tabular}{|l|}
5 \\
\end{tabular} & 1 & 99.9 & 99.8 & 10 & $99.8+$ & 20 & Lithic & Fire Cracked Chert & Thermal Shatter & 3 & \begin{tabular}{|l|l|}
6.4 \\
\end{tabular} & - & - & - & - & - & - & $7 / 26106$ & MRC/MB & \\
\hline 4 & 30.3 & 27 & - & - & - & - & - & 5 & 1 & 99.9 & 99.8 & 10 & $99.8+$ & 20 & Lithic & Debitage & Broken Flakes & 9 & 18 & - & - & - & - & - & 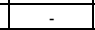 & $7 / 266 / 106$ & MRC/MB & \\
\hline 3 & 30.4 & 27 & - &  & - & - & - & 5 & 1 & 99.9 & 99.8 & 10 & $99.8+$ & 20 & Lithic & Debitage & \begin{tabular}{|c|c|c|c|} 
Comple Flakes \\
\end{tabular} & 4 & \begin{tabular}{|l}
54.4 \\
\end{tabular} & - & - & - & - & - & & $\begin{array}{l}7 / 26106 \\
\end{array}$ & MRC/MB & \\
\hline 3 & \begin{tabular}{|l|l|}
30.5 \\
\end{tabular} & 27 & - & - & - & - & - & 5 & 1 & 99.9 & 99.8 & 10 & $99.8+$ & 20 & \begin{tabular}{|l|l|l|l} 
Lithic \\
\end{tabular} & Debitage & \begin{tabular}{|l} 
Proximal Flakes \\
\end{tabular} & 5 & \begin{tabular}{|l|}
6.4 \\
\end{tabular} & - & - & - & - & - & - & $\begin{array}{l}7 / 261 / 06 \\
\end{array}$ & MRC/MB & \\
\hline 4 & 31 & 29 & - & - & - & - & - & 5 & 2 & 99.8 & 99.7 & 20 & $99.8-99.7$ & 30 & Lithic & Debitage & Flaking Shatter & 6 & \begin{tabular}{|l|l|}
18.4 \\
\end{tabular} & - & - & - & - & - & - & $7 / 26 / 106$ & MRC/MB & \\
\hline 4 & \begin{tabular}{|l|l|}
31.1 & \\
\end{tabular} & 29 & - & - & - & - & - & 5 & 2 & 99.8 & 99.7 & 20 & $99.8-99.7$ & 30 & Lithic & Debitage & Broken Flakes & 2 & \begin{tabular}{|l|l|} 
& \\
\end{tabular} & - & - & - & - & - & - & $7 / 26106$ & MRC/MB & \\
\hline 3 & \begin{tabular}{|l|l|}
31.2 \\
\end{tabular} & 29 & - & - & - & - & - & 5 & 2 & 99.8 & 99.7 & 20 & $99.8-99.7$ & 30 & Lithic & Debitage & \begin{tabular}{|l|l|l|} 
Comple Flakes \\
\end{tabular} & 2 & 2.6 & - & - & - & - & - & - & $7 / 26106$ & MRC/MB & \\
\hline 3 & 31.3 & 29 & - & - & - & - & - & \begin{tabular}{|l|}
5 \\
\end{tabular} & 2 & 99.8 & 99.7 & 20 & $99.8-99.7$ & 30 & Lithic & Debitage & \begin{tabular}{|l} 
Proximal Flakes \\
\end{tabular} & 3 & \begin{tabular}{|l|}
2.8 \\
\end{tabular} & - & - & - & - & - & - & $7 / 26106$ & MRC/MB & \\
\hline 4 & 32 & 31 & - & - & - & - & - & 5 & 3 & 99.7 & 99.6 & 30 & $99.7-99.6$ & 40 & Lithic & Debitage & Broken Flakes & 1 & 2.5 & - & - & - & - & - & - & $\begin{array}{l}7 / 26106 \\
\end{array}$ & MRC/MB & \\
\hline 3 & 32.1 & 31 & - & 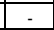 & - & - & - & 5 & 3 & 99.7 & 99.6 & 30 & $99.7-99.6$ & 40 & Lithic & Debitage & \begin{tabular}{|l|l|l|} 
Complete Flakes \\
\end{tabular} & 1 & 0.7 & - & - & - & - & - & - & $7 / 26 / 106$ & MRC/MB & \\
\hline 3 & 32.2 & 31 & - & - & - & - & - & \begin{tabular}{|l|}
5 \\
\end{tabular} & 3 & 99.7 & 99.6 & 30 & $99.7-99.6$ & 40 & Lithic & Debitage & Proximal Flakes & 1 & 1 & - & - & - & - & - & - & $7 / 26106$ & MRC/MB & \\
\hline 4 & 33 & 38 & - & - & - & - & - & 5 & 4 & 99.6 & 99.5 & 40 & $99.6-99.5$ & 50 & Lithic & Fire Cracked Chert & Thermal Shatter & 1 & 0.1 & . & - & - & - & . & - & $7 / 27106$ & MRC/MB & \\
\hline 3 & 33.1 & 38 & - & - & - & - & - & 5 & 4 & 99.6 & 99.5 & 40 & $99.6-99.5$ & 50 & Lithic & Debitage & \begin{tabular}{|c|} 
Complete Flakes \\
\end{tabular} & 1 & $<0.1$ & - & - & - & - & - & - & $7 / 27106$ & MRC/MB & \\
\hline 2 & 33.2 & 38 & - & - & - & - & - & 5 & 4 & 99.6 & 99.5 & 40 & $99.6-99.5$ & 50 & Lithic & Core & Core & 1 & 74.9 & - & - & - & - & - & - & $7 / 27106$ & MRC/MB & May be angular debris \\
\hline 4 & 34 & 37 & - & 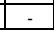 & - & & - & 6 & 1 & \begin{tabular}{ll|}
99.92 \\
\end{tabular} & 99.8 & 8 & $99.8+$ & 20 & Lithic & Fire Cracked Chert & Thermal Shatter & 1 & \begin{tabular}{|l|l|}
0.1 \\
\end{tabular} & - & - & - & - & - & - & \begin{tabular}{|l|l|}
$7 / 27106$ \\
\end{tabular} & MRC/MB & \\
\hline 4 & 34.1 & 37 & - & - & - & - & - & \begin{tabular}{|c|}
6 \\
\end{tabular} & 1 & 99.92 & 99.8 & 8 & $99.8+$ & 20 & Lithic & Debitage & Broken Flakes & 6 & 5.7 & - & - & - & - & - & - & $7 / 27106$ & MCC/RAB & \\
\hline 3 & 34.2 & 37 & - & - & - & - & - & 6 & 1 & 99.92 & 99.8 & 8 & $99.8+$ & 20 & Lithic & Debitage & \begin{tabular}{|c|} 
Complete Flakes \\
\end{tabular} & 6 & 35.8 & - & - & - & - & - & - & $7 / 27106$ & MCC/RAB & \\
\hline 3 & 34.3 & 37 & - & - & - & - & - & 6 & 1 & 99.92 & 99.8 & 8 & $99.8+$ & 20 & Lithic & Debitage & Proximal Flakes & 3 & 27.1 & - & - & - & - & - & - & $7 / 27106$ & MCC/RAB & \\
\hline 2 & 35 & 39 & - & - & - & - & - & \begin{tabular}{|c|}
6 \\
\end{tabular} & 2 & 99.8 & 99.7 & 20 & $99.8-99.7$ & 30 & Lithic & Formal Tool & Biface & 1 & \begin{tabular}{|l|l}
22.5 \\
\end{tabular} & - & - & - & - & - & - & $7 / 27106$ & MCC/RAB & Indeterminate \\
\hline 4 & 35.1 & 39 & - & - & - & - & - & 6 & 2 & 99.8 & 99.7 & 20 & $99.8-99.7$ & 30 & Lithic & Fire Cracked Chert & Thermal Shatter & 1 & 0.2 & - & - & - & - & - & - & $\begin{array}{l}7 / 27106 \\
\end{array}$ & MCC/RAB & \\
\hline 4 & \begin{tabular}{|l|}
35.2 \\
\end{tabular} & 39 & - & & - & & & 6 & 2 & 99.8 & 99.7 & 20 & $99.8-99.7$ & 30 & Lithic & Debitage & Broken Flakes & 3 & 4.2 & & & & & & & 7/27/106 & MCC/RAB & \\
\hline
\end{tabular}


Table C.1. Specimen Inventory for Site 41KM225 (continued)

\begin{tabular}{|c|c|c|c|c|c|c|c|c|c|c|c|c|c|c|c|c|c|c|c|c|c|c|c|c|c|c|c|c|}
\hline Bag & Lot\# & Bag \# & Ftr.\# & ss \# & FS\# & $\begin{array}{l}{ }^{*} \text { ST \# } \\
\end{array}$ & Shot\# & Unit & Level & \begin{tabular}{|c} 
Top Elev. \\
$(\mathrm{m})$
\end{tabular} & \begin{tabular}{|c} 
Bottom \\
Elev. $(m)$
\end{tabular} & $\begin{array}{c}\text { Begin } \\
\text { Depth* }\end{array}$ & \begin{tabular}{|c|} 
Elevation \\
Range
\end{tabular} & $\begin{array}{c}\text { End } \\
\text { Depth }\end{array}$ & \begin{tabular}{|l|} 
Artifiact \\
Category \\
\end{tabular} & Artifact Type & Arrifact Description & \# & \begin{tabular}{|c} 
Weight \\
$(\mathrm{g})$
\end{tabular} & $\begin{array}{l}0.5 \mathrm{~cm} \\
\text { FCR\# }\end{array}$ & $\begin{array}{l}0.5 \mathrm{~cm} \\
\mathrm{~F} C \mathrm{(kg}(\mathrm{kg})\end{array}$ & $\begin{array}{r}5-10 \mathrm{~cm} \\
\text { FCR\# } \\
\end{array}$ & $\begin{array}{l}5-10 \mathrm{~cm} \\
\operatorname{FCR}(\mathrm{kg}) \\
\end{array}$ & $\begin{array}{r}10-15 \mathrm{~cm} \\
\text { FCR\# } \\
\end{array}$ & $\begin{array}{l}10-15 \mathrm{~cm} \\
\text { FCR }(\mathrm{kg})\end{array}$ & Date & Initials & Comments \\
\hline 3 & \begin{tabular}{|l|}
35.3 \\
\end{tabular} & 39 & - & - & - & - & - & 6 & 2 & 99.8 & 99.7 & 20 & \begin{tabular}{|l|}
$99.8-99.7$ \\
\end{tabular} & 30 & Lithic & Debitage & Complete Flakes & 2 & 11.9 & - & - & - & - & - & - & $7 / 27106$ & MCC/RAB & \\
\hline 3 & \begin{tabular}{|l|l|}
35.4 \\
\end{tabular} & 39 & - & - & 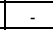 & - & - & 6 & 2 & 99.8 & 99.7 & 20 & \begin{tabular}{|l|l|}
$99.8-99.7$ \\
\end{tabular} & 30 & Lithic & Debitage & Proximal Flakes & 1 & 0.2 & - & - & - & - & - & - & $7 / 27106$ & MCC/RAB & \\
\hline 1 & 36 & 41 & - & - & - & - & - & 6 & 3 & 99.7 & 99.6 & 30 & \begin{tabular}{|l|}
$99.7-99.6$ \\
\end{tabular} & 40 & Lithic & Groundstone & Mano & 1 & \begin{tabular}{|l|}
149.3 \\
\end{tabular} & - & - & - & - & - & - & $7 / 27106$ & MCC/RAB & \\
\hline 4 & \begin{tabular}{|l|}
36.1 \\
\end{tabular} & 41 & - & - & - & - & - & 6 & 3 & $\begin{array}{l}99.7 \\
\end{array}$ & 99.6 & 30 & \begin{tabular}{|l|}
$99.7-99.6$ \\
\end{tabular} & 40 & Lithic & Debitage & Broken Flakes & 1 & 2.3 & - & - & 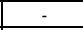 & - & -1 & - & \begin{tabular}{|l|l|}
$7 / 27106$ \\
\end{tabular} & MCC/RAB & \\
\hline 3 & \begin{tabular}{|l|}
36.2 \\
\end{tabular} & 41 & - & - & - & - & - & 6 & 3 & $\begin{array}{l}99.7 \\
\end{array}$ & 99.6 & 30 & \begin{tabular}{|c|c|}
$99.7-99.6$ \\
\end{tabular} & 40 & Lithic & Debitage & Complete Flakes & 4 & 34.2 & - & - & - & - & - & - & $7 / 27 / 106$ & MCC/RAB & \\
\hline 3 & 36.3 & 41 & - & - & - & - & - & 6 & 3 & 99.7 & 99.6 & 30 & \begin{tabular}{|l|}
$99.7-99.6$ \\
\end{tabular} & 40 & Lithic & Debitage & \begin{tabular}{|l|} 
Proximal Flakes \\
\end{tabular} & 2 & 8.5 & - & - & - & -5 & - & - & $7 / 27 / 106$ & MCC/RAB & \\
\hline 4 & \begin{tabular}{|l|}
37 \\
\end{tabular} & 34 & - & $\cdot$ & - & 3 & - & & & - & & 20 & & 40 & Lithic & Debitage & Broken Flakes & 2 & 3.3 & - & - & - & - & - & - & \begin{tabular}{|l|l|}
$7 / 27106$ \\
\end{tabular} & TN/CM & Originally shovel test T1 \\
\hline 3 & \begin{tabular}{|l|l|}
37.1 \\
\end{tabular} & 34 & - & - & - & 3 & - & - & - & - & - & 20 & - & 40 & Lithic & Debitage & Complete Flakes & 2 & 1.1 & - & - & - & - & - & - & $7 / 27106$ & TN/CM & Originally shovel test T1 \\
\hline 4 & 37.2 & 34 &. & . & . & 3 & - & - & . & - & - & 20 & - & 40 & Lithic & Formal Tool & Scraper & 1 & 19.5 & - & . & - & . & - & - & 7/27/106 & $\mathrm{TN} / \mathrm{CM}$ & $\begin{array}{l}\text { Originally shovel test T1 - } \\
\text { indeterminate scraper }\end{array}$ \\
\hline 3 & 38 & 35 & 1 & - & - & 4 & - & - & - & - & - & 0 & - & 20 & Lithic & Debitage & Proximal Flakes & 1 & 1.7 & - & - & - & - & - & - & $7 / 27 / 106$ & TN/CM & Originally shovel test T2 \\
\hline 4 & 39 & 36 & 1 & - & - & 4 & - & - & - & - & - & 20 & - & 40 & Lithic & Debitage & Broken Flakes & 2 & 2.7 & - & - & - & - & - & - & $7 / 27 / 06$ & TN/CM & Originally shovel test T2 \\
\hline 3 & \begin{tabular}{|l|l|}
39.1 \\
\end{tabular} & 36 & 1 & - & - & 4 & - & - & - & - & - & 20 & - & 40 & Lithic & Debitage & Complete Flakes & 2 & 27.5 & & - & - & - & - & - & $7 / 27 / 06$ & TN/CM & Originally shovel test $\mathrm{T} 2$ \\
\hline 3 & \begin{tabular}{|l|}
39.2 \\
\end{tabular} & 36 & 1 & - & - & 4 & - & - & - & - & - & 20 & - & 40 & Lithic & Debitage & \begin{tabular}{|l} 
Proximal Flakes \\
\end{tabular} & 3 & 33.7 & - & - & - & - & - & - & $7 / 277106$ & TN/CM & \begin{tabular}{|l} 
Originally shovel test $\mathrm{T} 2$ \\
\end{tabular} \\
\hline 5 & 40 & 40 & 1 & C-2 & - & 4 & - & - & - & - & - & 24 & - & 26 & \begin{tabular}{|l|} 
Special \\
Sample
\end{tabular} & Soil Sample & Soil Sample & & 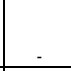 & - & - & - & - & - &  & $7 / 27 / 106$ & TN/CM & $\begin{array}{l}\begin{array}{l}\text { Ooriginally shovel test T1 - soil } \\
\text { from burned rock midden } \\
\text { across road }\end{array} \\
\end{array}$ \\
\hline 4 & 41 & 42 & 1 & - & - & 4 & - & - & - & - & - & 40 & - & 44 & \begin{tabular}{|l|} 
Lithic \\
\end{tabular} & Fire Cracked Chert & Thermal Shatter & 1 & 1.8 & - & - & - & - & - & - & $7 / 27706$ & CN/MB & Originally shovel test T2 \\
\hline 4 & \begin{tabular}{|l|l|}
41.1 \\
\end{tabular} & 42 & 1 & - & - & 4 & - & - & - & - & - & 40 & - & 44 & Lithic & Debitage & Broken Flakes & 2 & 6 & - & - & - & - & - & - & $7 / 27106$ & CN/MB & Originally shovel test $\mathrm{T} 2$ \\
\hline 4 & 42 & 24 & & 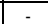 & - & 2 & - & - & - & - & - & 15 & - & 20 & Lithic & Debitage & $\begin{array}{l}\text { Broken Flakes } \\
\end{array}$ & 3 & 13.1 & - & - & - & - & - & - & $7 / 24 / 06$ & $R A B$ & \\
\hline$n / a$ & 43 & 19 & - & C-1 & . & - & . & 1 & 5 & 99.5 & 99.4 & 50 & 99.5 - 99.4 & 60 & \begin{tabular}{|l|} 
Special \\
Sample
\end{tabular} & Charcoal & Charcoal & 1 & 0.1 & - & - & . & - & . & - & 7/255/06 & RAB/MRC & $\begin{array}{l}\text { Found in screen - not } \\
\text { returned from analyst }\end{array}$ \\
\hline $\mathrm{n} / \mathrm{a}$ & $\mathrm{n} / \mathrm{a}$ & 6 & - & - & - & - & - & 2 & 1 & 100 & 99.8 & 0 & $99.8+$ & 20 & Lithic & Fire Cracked Rock & Fire Cracked Rock & 5 & 0.8 & 5 & 0.8 & - & - & - & - & $7 / 25506$ & TN/CM & \\
\hline $\mathrm{n} / \mathrm{a}$ & n/a & 7 & - & - & - & - & - & 1 & 1 & 99.91 & 99.8 & 9 & $99.8+$ & 20 & Lithic & Fire Cracked Rock & Fire Cracked Rock & 9 & 0.3 & 7 & $<0.1$ & 2 & 0.2 & - & - & $7 / 25 / 06$ & RAB/MRC & Discarded in field \\
\hline $\mathrm{n} / \mathrm{a}$ & $n / a$ & 10 & - & - & - & - & - & 1 & 2 & 99.8 & 99.7 & 20 & \begin{tabular}{|l|}
$99.8-99.7$ \\
\end{tabular} & 30 & Lithic & Fire Cracked Rock & Fire Cracked Rock & 4 & 0.2 & 2 & $<0.1$ & 2 & 0.1 & - & - & $7 / 25506$ & RAB/MRC & Discarded in field \\
\hline$n / a$ & n/a & 14 & - & - & - & - & - & 3 & 4 & 99.5 & 99.4 & 40 & \begin{tabular}{|l|}
$99.5-99.4$ \\
\end{tabular} & 50 & Lithic & Fire Cracked Rock & Fire Cracked Rock & 2 & & - & & 2 & 1 & - & - & $7 / 25 / 06$ & MRC/MB & FCR discarded in field \\
\hline n/a & $n / a$ & 17 & - & - & - & - & - & 1 & 4 & 99.6 & 99.5 & 40 & \begin{tabular}{|l|l|}
$99.6-99.5$ \\
\end{tabular} & 50 & Lithic & Fire Cracked Rock & Fire Cracked Rock & 4 & 0.1 & 4 & 0.1 & & & - & - & $7 / 25 / 06$ & RAB/MRC & Discarded in field \\
\hline n/a & n/a & 26 & - & - & - & - & - & 4 & 1 & 99.9 & 99.8 & 10 & $99.8+\mathrm{r}+\mathrm{C}$ & 20 & Lithic & \begin{tabular}{|l|} 
Fire Cracked Rock \\
\end{tabular} & \begin{tabular}{|l} 
Fire Cracked Rock \\
\end{tabular} & 1 & & & & 1 & 0.2 & $-\sigma_{-1}$ & - & $7 / 26 / 06$ & MCC/RAB & FCR discarded in field \\
\hline$n / a$ & $n / a$ & 27 & - & - & - & - & - & 5 & 1 & 99.9 & 99.8 & 10 & $99.8+$ & 20 & Lithic & Fire Cracked Rock & Fire Cracked Rock & 10 & - & 4 & 0.9 & 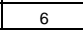 & 1.5 & - & - & $7 / 26 / 106$ & MRC/MB & FCR discarded in field \\
\hline $\mathrm{n} / \mathrm{a}$ & $\mathrm{n} / \mathrm{a}$ & 28 & - & - & - & - & - & 4 & 2 & 99.8 & 99.7 & 20 & \begin{tabular}{|l|}
$99.8-99.7$ \\
\end{tabular} & 30 & Lithic & Fire Cracked Rock & \begin{tabular}{|l|} 
Fire Cracked Rock \\
\end{tabular} & \begin{tabular}{|c|}
6 \\
\end{tabular} & - & 2 & $<0.1$ & 4 & 0.3 & - & - & $7 / 261 / 06$ & MCC/RAB & FCR discarded in field \\
\hline n/a & n/a & 34 & - & & - & 3 & - & & & - & - & 20 & - & 40 & Lithic & Fire Cracked Rock & Fire Cracked Rock & 1 & - & - & - & 1 & - & - & . & 7/27/106 & TN/CM & \begin{tabular}{|l} 
Originally shovel test T1 \\
FCR discarded in field
\end{tabular} \\
\hline n/a & $n / a$ & 35 & 1 & - & - & 4 & - & . & - & 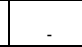 & - & 0 & - & 20 & Lithic & Fire Cracked Rock & Fire Cracked Rock & 101 & - & $75+$ & - & 24 & - & 2 & - & 7/277/106 & $\mathrm{TN} / \mathrm{CM}$ & $\begin{array}{l}\text { Originally shovel test T2 - } \\
\text { FCR discarded in field }\end{array}$ \\
\hline n/a & $\mathrm{n} / \mathrm{a}$ & 36 & 1 & . & - & 4 & - & . & . & - & - & 20 & - & 40 & Lithic & Fire Cracked Rock & Fire Cracked Rock & 124 & . & $75+$ & - & 48 & - & 2 & 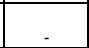 & 7/277/106 & TN/CM & $\begin{array}{l}\text { Originally shovel test T2 - } \\
\text { FCR discarded in field }\end{array}$ \\
\hline $\mathrm{n} / \mathrm{a}$ & $\mathrm{n} / \mathrm{a}$ & 37 & & - & 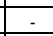 & -1 & - & 6 & 1 & 99.92 & 99.8 & 8 & $99.8+$ & 20 & Lithic & Fire Cracked Rock & \begin{tabular}{|l|} 
Fire Cracked Rock \\
\end{tabular} & 1 & - & & - & 1 & $<0.1$ & & & $7 / 27106$ & MCC/RAB & FCR discarded in field \\
\hline$n / a$ & $n / a$ & 41 & - & - & - & - & - & 6 & 3 & 99.7 & 99.6 & 30 & \begin{tabular}{|l|}
$99.7-99.6$ \\
\end{tabular} & 40 & Lithic & Fire Cracked Rock & \begin{tabular}{|l|} 
Fire Cracked Rock \\
\end{tabular} & 2 & - & - & - & 2 & 0.3 & - & - & $7 / 27106$ & MCC/RAB & FCR discarded in field \\
\hline $\mathrm{n} / \mathrm{a}$ & n/a & 42 & 1 & - & - & 4 & - & $\dot{-}$ & - & - & - & 40 & - & 44 & Lithic & Fire Cracked Rock & Fire Cracked Rock & 31 & . & $20+$ & - & 10 & - & 1 & - & $7 / 27106$ & $\mathrm{CN} / \mathrm{MB}$ & $\begin{array}{l}\text { Originally shovel test T2 - } \\
\text { FCR discarded in field }\end{array}$ \\
\hline $\mathrm{n} / \mathrm{a}$ & $n / a$ & n/a & $\dot{-}$ & & - & - &  & 3 & 1 & 99.8 & 99.7 & 10 & \begin{tabular}{|l|}
$99.8-99.7$ \\
\end{tabular} & 20 & \begin{tabular}{|l|} 
Lithic \\
\end{tabular} & Fire Cracked Rock & Fire Cracked Rock & 2 & - & - & - & 2 & 2 & - & & 7/255/06 & MRC & $\begin{array}{l}\text { No artifacts recovered - FCR } \\
\text { discarded in field }\end{array}$ \\
\hline n/a & $n / a$ & $n / a$ & - & - & - & 5 & - & - & - & - & . & 10 & - & 30 & Lithic & Fire Cracked Rock & Fire Cracked Rock & 15 & - & $10+$ & - & 3 & . & 2 & . & 77/27/06 & CN/MB & $\begin{array}{l}\text { Originally shovel test T3- } \\
\text { FCR discarded in field }\end{array}$ \\
\hline n/a & n/a & n/a & & & & 5 & & & & & & 30 & & 50 & Lithic & Fire Cracked Rock & Fire Cracked Rock & 20 & & $10+$ & & 10 & & & & $77 / 27106$ & CNIMB & $\begin{array}{l}\text { Originallly yhovel test T3- } \\
\text { FCR discarded in field }\end{array}$ \\
\hline
\end{tabular}

